\title{
UNIVERSIDADE DE SÃO PAULO
}

HUMANIDADES DIREITOS E OUTRAS LEGITIMIDADES

\section{Mobilidade Yanomami e Interculturalidade:}

Ecologia histórica, Alteridade e Resistência Cultural

Maurice Seiji Tomioka Nilsson

São Paulo, 2018 


\section{Mobilidade Yanomami e Interculturalidade:}

Ecologia histórica, Alteridade e Resistência Cultural

Versão corrigida

Tese apresentada ao Programa de Pós-Graduação interdisciplinar Humanidades Direitos e Outras Legitimidades, Diversitas, Universidade de São Paulo, como pré-requisito para obtenção do Título de Doutor em Ciências.

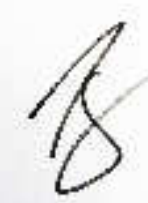

Orientador Prof. Doutor Gilson Schwartz

São Paulo, 2018 
Autorizo a reprodução e divulgação total ou parcial deste trabalho, por qualquer meio convencional ou eletrônico, para fins de estudo e pesquisa, desde que citada a fonte.

Nilsson, Maurice Seiji Tomioka

NN693m Mobilidade Yanomami e Interculturalidade:

m Ecologia Histórica, Alteridade e resistência cultural / Maurice Seiji Tomioka Nilsson ; orientador Gilson Liberato Schwartz. - São Paulo, 2018.

$$
220 \mathrm{f} \text {. }
$$

Tese (Doutorado) - Programa de Pós-Graduação Humanidades, Direitos e Outras Legitimidades da Universidade de São Paulo. Área de concentração: Humanidades, Direitos e Outras Legitimidades.

1. Povos Indígenas. 2. Amazônia. 3. Yanomami. 4. Ecologia Histórica. 5. Antropologia Reversa. I. Schwartz, Gilson Liberato, orient. II. Título. 



\section{Agradecimentos}

Uma pesquisa não se faz só com foco nos livros, nem só na razão, então, começo agradecendo as doses de amor e compreensão necessárias para completar a jornada proposta: à Andrea Lamberts, à Verena e ao Érico, a toda minha família extensa, Tsugui e Moacyr (in memorian - poxa, acho que gostarias de estar nesse momento...), Akira e Mônica, ao Gustavo Izumi; Teiji, Salete, Machi (in memorian), Sergio, Marcelo e Ana; Walter, Angela, Denise, Gustavo e Patricia.

Agradeço por demais a Davi Kopenawa, por me receber em sua casa, bem como a toda comunidade do Watoriki, com quem compartilhei, especialmente Lourival, Rosa, Fatima, Justino, Felicia, Roberto, Genesio, Bocome, Vovô Luis, Lucas, Antonio, Islik, Raimundo, Carlos, Joseca, Walmir, Ehuana, Pedrinho e Mocinha, dentre os demais dessa comunidade. Igualmente ao pessoal do Toototopi, especialmente na figura de Totô, meu primeiro anfitrião ali, Dimas e Esther, Jeremias, Bilo, seu finado pai, Luixi, Roque, Adriano, Barbosa, Adriana, Magoado, Rogel, Lia, Lara, Cesar, Tião, Nadir, Cecilia, Haroldo, Maristera, Meco, Tomé, Sarnesi, Romario, Fatima, Gonçalo, Manuel, Ari, Levi, Bras, Abraão, Geraldo, Gerson, Dalila, Creusa, Julia. Do Homoxi, igualmente bem recebido, agradeço a Romão, Carlussi, Kairama, Makureba, Minero, João, Bauro, Menininho, Garcia, Robi, Henaxi, Henato, Maria, Helena, Maranhão, em nome de todos os outros. Do Auaris, agradeço a Resende, Palekoko, Carlos, Chileno e Selma, Waxi, Ribamar, Marinaldo, Kopari, Siwë, aos Yekuana Mauricio, Henrique, Thomé. Do Catrimani agradeço ao Barbadinho, Marino, Mozarildo, Ivan, Tino. Do Parawau, agradeço a Atabai, Kazuzo, Helio, Geraldo, Carlita, Mokinha, Edsão, Edu, Saldanha (me acompanhou à XamatuaPora), Margarida. Do Marauiá, agradeço a Renato, Otavio, Tiago, Jovino, Candinho, Jorge, Alberto, Adriano, Carlinhos, Daniel, Sabá, Patricio, Eduardo, Samuel, Lourenço, Nilton, Bento, e aos professores.Batista, Manuel, Waldemar, Vitorino. Ainda de outras regiões, tenho a agradecer a convivência com Xaporita, Juninho, Gerson, Edgar, Albino, Marcelo, Hiton, Santarém, Eliseu, Ivan, Toinho Morzaniel. A todos os estudantes Yanomami, patapë e Patayomapë que não citei nominalmente mas comos quais convivi.

Aos professores, a quem ensinei e muito aprendi também; uma arte que aprendemos todos com Paulo Freire, educar-se mutuamente. Deles, eu destaco em gratidão ao Ivan Yoroana, ao Enio Mayanawa, Dario Kopenawa Yawarioma, Alfredo Himotona, Gaucho Sisipino, Amazonas, Magno, Marinaldo Cuyadin, Marinaldo Sanöma, Eudes Koyorino, Jose 
Arari, Sidinei Nanari, Alipio, Genivaldo Krepuna, Luis Yaritha, Anselmo, Turio, Apolo, Rafael Wanari, Antonio Tihiri, Pratão Ixarori, Nelson, Marconi, Cesar, a três que não pude agradecer a tempo .

A Bruce Albert, pelos ensinamentos escritos e pelas conversas proveitosas, além de todo incentivo. A François Michel Le Tourneau, William Milliken, Alcida Ramos, Claudia Andujar e muito especialmente a Carlo Zacquini. Aos companheiros da saudosa CCPY (acima, estão os quatro fundadores) Deise Alves Francisco e Claudio Esteves de Oliveira (Urihi), à Lidia Montanha Castro, Luis Fernando Wixaxina (in memorian), Simone de Cassia Ribeiro, Helder Perri Ferreira, Clarisse do Carmo Jabur, Evandro, Sidinaldo, Marcolino, Marcos Wesley, Matthieu Lena, Ana Paula Souto Maior, Ana Maria Antunes Machado, Giseli Deprá, Maria Auxiliadora Carvalho, Sara Gaia, Hanna Limulja, Moreno, Vicente, Marina, Ednelson Pereira Makuxi, Renata Guerreiro, Eliane, Angela, Ciro. Aos colegas da Urihi, Adonilde, Francisca, Especialmente ao Richard Prayatima Vanderlan - parabéns pela nova cria, Marcão, Luis Henrique, Gustavo Villas, Edson Sato e Laura, Amanda Frota, Kelly Cavalette, Bruno Alcântara, George, Adriana e Ednéia, Eliseu Müzel, Nara Fagundes, Cameron e Angela, Marinho, João Paulo de Sousa e Samara. aos guerreiros do CIR, Telmo, Jaci, Joênia Wapichana, Genisvan André, Marinaldo.Aos amigos da Secoya, Paulo Welker, Silvio Cavuscens, sobretudo.

Os Yanomami estavam em minhas preocupações durante a graduação em geografia, concomitante ao momento mais crítico da sua História, a invasão garimpeira; aí nascem as primeiras leituras inspiradoras, a quem eu agradeço, e não esqueço, pois mais tarde venho a conhecer pessoalmente: a Manuela Carneiro da Cunha, então presidenta da ABA. Aos integrantes do Centro de Trabalho Indigenista, por onde comecei a atuação indigenista, especialmente aos fundadores: Gilberto Azanha, Maria Elisa Ladeira, Virginia Valadão (in memorian), Vincent Carelli; ao Rogerio Resende, agradeço em especial por me abrir essa oportunidade. Adriana Felipim, Daniel Pierri, Dafran, Geraldo, Bona, Detão, Helena Ladeira, Omar Silveira, Maria Ines Ladeira, Yanci, pela sua maravilhosa tese. Ao Altair Algayer e a Marcelo dos Santos.

Aos outros colegas de indigenismo, Isabel Modercin, Rosario, Guga e Ana, Lara Erendira,a Mauricio Torres, a André Ramos, ao Cesar, ao Rafael Santos, Diogo Oliveira, a Geraldo 
Andrello, Alicia Rolla, Beto Ricardo, Hernanes e Laise, Melissa Oliveira, Cleber Gesteira Mattos.

Aos Terena de Cachoeirinha especialmente, Elcio Piuta Albuquerque, Sabino Albuquerque, Elvis e a nova geração, anapoyaqwê! Aos Kanoe Tiramãtu e Purá, aos Auwe Xavante, especialmente Lucas Owau, Aloisio, Tseredzaró, Hiparidi, e aos outros que através deles pude conhecer; wẽdi! aos Munduruku, especialmente Ademir Kabá, Claudete Saw, Ivanilda Karu, Jairo Saw, Sawe! Aos guarani de Ywyty Guasu, em especial Toninho Awá e filhos, Tidju, extenso aos demais de outras terras, Altino, Kerexu, aguyweté! Aos Apurinã, especialmente Francisco, seu pai, Geraldo, Francisco (Camicuã), Manoel, aos ouros todos que conheci, aos Jamamadi também. Aos Pankararu Christiane, Alexandre, Seu Danda, aos Xokó Cacique Bá, Karine, aos Xacriabá sobretudo ao Seu Valdemar, a turma toda que nos acompanhou.

Aos Professores do Diversitas, especialmente ao meu Orientador Gilson Schwartz, à Zilda Yokoi, Antonio Ribeiro Almeida Jr., Luis Galeão, Maria das Graças Nascimento, Maria Constanza Pissarra, Claudia Moraes, Mauricio Cardoso e Margarida Maria Moura. Aos colegas de turma no Diversitas, especialmente a André Augusto Bezerra (e Glaucia e filhos), a Diego Viana, Luis Checchia, Regiane Oliveira, Roberta Batistella. À Teresa Telles, a Eduardo Kishimoto, Michely, Marcelo.

Aos velhos colegas de Geografia, aos Professores Regina Sader, José William Vesentini, José Pereira de Queiroz Neto, Ariovaldo Oliveira, Milton Santos, Francisco Scarlatto, Tonico (in memorian), Marangoni, e a inestimável colaboração de Sueli Angelo. Dos amigos, agradeço a todos, mas cito: Lucia Cavalieri e Zé, Edelci Nunes, Ana Elisa Rodrigues Pereira, Eduardo Schiavone Cardoso, Regina Ramirez, Gueth, Adriana Matrangolo, Adriana Bernardes, Rosana Gasparin, Roseli Alvim Sanches, Cecilia Alarsa, Amanda Almeida, Ana Valeria (História), Juliano Spyer, Rosemaire Almeida. Do Colégio Galileu Galilei, agradeço a Marcelo Trindade dos Santos, Marcelo Pretto, Marcelo Cipolla, Herta Franco, Daniela Komives, Carmina Juarez, Geórgia Lengos e Claudia Mercadante.

Aos Professores da UFSC, Gabriel Coutinho Barbosa, Jose Kelly Luciani, Oscar Calavia Saez, Rafael Devos e Viviane, Jeremy Detourche, Marnio Teixeira e Miriam Hartung, Edviges Ioris, aos colegas de aula de etnologia, Nicole Pinto e João Vianna, Diogenes Cariaga, Brisa Catão; a Corrado Dalmonego. Também a Gustavo Jugend, Gustavo Fontes, 
Andrea Oliveira.

Aos professores e colegas de Inpa a começar pelo meu Orientador Philip Fearnside, a Charles Clement, a Claudia Keller, Gonçalo Ferraz, Flavia Costa, Bill Magnusson, Albertina Lima, Jose Luis de Camargo, Thiago Izzo e Idolde; aos colegas, Igor (hoje, Ufam) Cintia, João Campos, Xuleta, Anderson, Adriana, Priscila, Guigas, Bernardo mas especialmente ao Bruno Luise, muito companheiro, e de troca de ideias e Marcelino Soyinka e Helena, sua mãe especial,que me acolheram nos trabalhos indigenistas. Ainda do Inpa, agradeço a André Braga Junqueira, Ana Bochini, Juliana Schietti e Fabricio Baccaro, Rafael Bernhard, Tais e Helder, onde pude conviver com várias possibilidades do fazer ciência. Ao Eduardo Goes Neves (que me conhece desde o ensino médio, era monitor de História do colégio), por me proporcionar um encontro com a Arqueologia Amazônica, aqueles que eu conhecia de leitura, mas não pessoalmente, até então.

Aos amigos que sempre incentivaram minha pesquisa, Thiago Cardoso, Marilena Altenfelder Campos, Reinaldo Imbrosio Barbosa, Josi Cerveira, Carolina Ferreira, Carolina Matosinhos, Marcos Almeida Mattos e Camila Bilaardt, Valquiria Garrote e Gleisson, Iara Vasco Ferreira, Deisi e Felipe, Cintia Rocha, Ana Ramo, Lilian Parra, Julia, Rafael Moreira, Deo Lembá. Paulo Cabral, José Fernando Araujo, Henyo Barreto Trindade, André Rocha Haudenschild.

Ao povo da Capoeira Angola, além de me permitir olhar ao mundo de outros ângulos e movimentos, tiveram paciência com minhas ausências nas rodas. Ao Mestre Jorge dos Santos Jogo de Dentro, aos professores Pedro e Difunto, e a Julio, Zé, Ana, Paola, Alejo, Patrick, Renato, Marcelo, Bianca, Lila, Alice, de SP: CM Pita, Alan, Simone, Mestra Janja, Poloca e Paula (Nzinga), Daniel, Anna Maria Andrade, Leandro, Ricardo Cassis, Ricardo Maio. Os de vadiagem Tiago, Pedro Felipe, Raphael Patrocinio e Roberta, Favio, Mestra Elma, Jacaré e Maripoza, e de outras rodas, pelo Brasil. Porque uma tese também se constrói de seu contraponto, de se abster da obsessão investigativa e procurar outras maneiras de enxergar o mundo

Mas quero agradecer ao que viabilizam a realização da pesquisa científica no Brasil, em geral, cientistas, a cuidar das universidades centros de pesquisa, agências de fomento, dentre as quais eu agradeço à Capes, pela bolsa e oportunidade, Ao Inpe, ao IBGE, sobretudo a partir 
do Governo Lula, por disponibilizarem o acervo em formato digital, viabilizando muitas pesquisas. Que o exemplo seja seguido, as universidade públicas e gratuitas, e o jeito Brasileiro de valorizar a ciência e pesquisa seja fortalecido e fortaleça o seu reconhecimento, enquanto potência democrática. Por fim, quero fazer um agradecimento especial a Alexandra Elbakyan, por ter mediado um ponto de encontro entre colaboradores em sua maioria produzindo ciência com recursos públicos e investimentos de toda a sociedade e cujos resultados vêm sendo privatizados. 


\section{Resumo}

\section{TOMIOKA NILSSON, Maurice Seiji: Mobilidade Yanomami e interculturalidade:} ecologia histórica, alteridade, e resistência cultural. 2017: 212p. tese (doutorado em Ciências, pelo Programa Humanidades, Direitos e Outras Legitimidades), Diversitas, Universidade de São Paulo. São Paulo, 2018

A mobilidade dos Yanomami tem papel decisivo na construção da paisagem amazônica ao produzir clareiras a serem regeneradas após cada mudança de residência. Esse processo não deve ser reduzido apenas ao seu aspecto de ecologia histórica, pois está intimamente ligado à organização social horizontalizada, orientada pelas alianças intercomunitárias. Nesse estudo é proposto um mapeamento das trajetórias de alguns grupos Yanomami, no Toototopi, Homoxi, Marauiá e os resistentes ao contato, Moxihatetemapë. Nos três primeiros, onde o posto de contato exerce uma atração pelo diferencial de potencialidades de troca, recuperei em minha experiência de quase uma década nesses lugares, para investigar a intencionalidade dessa mobilidade e de sua continuidade perante a novidade representada pelo posto. Os Yanomami souberam manter uma relação pendular de aproximação e afastamento dos postos de contato permanente, utilizando-se de segundas residências, próximas e longe do posto, do rio, aproveitando o que lhes interessava na relação de contato e recusando os elementos que pudessem levar a um sistema colonial ou a uma perversão das relações sociais com a criação de algum mecanismo coercitivo; isso se fez mediante a uma atualização sobre a alteridade, uma antropologia reversa, enquanto os estrangeiros ainda eram minoritários. Percebendo a intencionalidade estratégica desse ato, cuja recusa radical é a resistência ao contato dos Moxihatetemapë. Há uma relação prioritária com a construção (e defesa) da paisagem amazônica, expressa na cosmopolítica de Davi Kopenawa.

Palavras chave: povos indígenas, Yanomami, mobilidade residencial, interculturalidade, ecologia histórica, antropologia reversa, politica contra o Estado. 


\begin{abstract}
TOMIOKA NILSSON, Maurice Seiji: Yanomami Mobility and interculturality: historical ecology, alterity, and cultural resistence. 2017: 212p. thesis (doctoring in Sciences, at the Humanities, wrights and Others Legitimacies Program), Diversitas, University of São Paulo. São Paulo, 2018
\end{abstract}

The mobility of the Yanomami plays a decisive role in the construction of the Amazon landscape by producing clearings to be regenerated after their moving among residences. This process should not be reduced only to its historical ecology, since it is closely linked to the social organization horizontality, regulated by inter-community alliances. In this study I mapped the trajectories of some Yanomami groups in Toototopi, Homoxi, Marauiá and Moxihatetemapë, the latter resistant to contact. In the other three, the "attraction post" established by the government causes both an attraction and a resistance given its exchange potential. My experience of almost a decade in these posts investigating the intentionality of indigeneous mobility and its continuity is reviewed. The Yanomami have invented intelligent ways to maintain a pendular relation to be near and distant from these permanent contact sites, using second residences, near and far from health services, by the river or taking advantage of what interested them in their contact while refusing the elements that could lead to a colonial system or a perversion of social relations due to the creation of some coercive mechanism; this was done through an update on alterity, a reverse anthropology, until foreigners were still in minority. The strategic intentionality of this processes of radical refusal mirrors the resistance to contact of the Moxihatetemapë. I therefore advocate a relation between this and the construction (and defense) of the Amazonian landscape, expressed in the cosmopolitics of Davi Kopenawa.

Keywords: indigenous peoples, Yanomami, residential mobility, interculturality, historical ecology, reverse anthropology, against-the-State politics 


\section{witipii ya thëã rapemai tha?}

TOMIOKA NILSSON, Maurice Seiji: Yanomami huuheyatiwei thë̃̃ ai napëpëxë thëpë tayouwei: urihi thapraiwei, ai thëpë napëmaiwei, yanomami thaikuapënaha thëpë noamaiwei. 2017: 212p. tese (doctoring in Sciences, at the Humanities, wrights and Others Legitimacies Program), Diversitas, Universidade de São Paulo. São Paulo, 2017

Yanomami thëpë huuheyatitëhë urihixaaripramaihe, inaha theka thëpë thathe tëhë thëpë hutumoutëhë ihi hutu wãropatarayu, thëpë ai yano tute thaihe tëhë. Mihi urihi xaaripramaitweiha yanomami thëpë nohimayu thëã pree kua:Yanomami thëpëni ai yanomami nosiamoupuo pihioimihe, thëpëni noaohotamai pihioimihe thëpë xiro nomihiayu pihiohe ai nohimouwei thëpëxë. Kami yani yanomami urihipi huu nomihiwei thëäha ya utupë thaprarema

Toototopi urihipëxë, Marauiá urihipixë, Homoxi urihipëxë, ai Moxihatetemapëxë; mihi thëpëni napëpëxë ai yanomamipëxë taamou pihioimi makii. Ya thë urihi utupë thaprarema. Napë yanopë posto de contatopë kuoweihami, yanomami thëpëni riã matehipë nomihiayu kutaeni, thëpë ahetemaihe. Inaha kuë kutaeni, mihami,Toototopi,xë, Marauiáxë, Homoxi urihipëxë, kihami ya kuo tëhë, ya thë pihihomoprariowei thëã onimama, inaha ya riã thëã wãri: yanomami thëpë pihikupënaha pë kuowini inaha posto tute a kuo tëhë winaha thëpë huи xoao pihiotëhë thëpë thathe tha? Kama pë thai kuapënaha urihipë hami thëpë that pihio xoahe. Inaha kua kutaent urihipëhami huuwei thë hea xoa, thëpë ahetouhe makii thëpë praha huu yapaihe, napëprouowi thëãha thëpë pihikurayoma yaro, xawara kuowini waitherikuowint thëpë pihimoyamirayoma, kuë yaro ai yano tute prahaihami thëpë pree thaprarema, porokatae yano kipë kuo tëhë, thëpë peximaiowi thëpë thathe. Kuё yaro napë thapëhenaha, thëpë nohimou makii thëpё pree napëmoupиo, thepë nosiamoupиo tëhë, nарёрё noa rahuhai tëhë, napëpë waritikohe kuotëhë yanomami thëpë prahamathetuo. Yanomami pëni napëyanohami waisipë pihimoyamirayoma, winaha napë kuapënaha waiterimouwi thë kua hetuo. Yami nарёрё kиo tëhë posto hami thëpë nosiamouwei thë kuopuo. Киё yaro moxihatetemapë ahetou pihioimihe, pë kiri yaro garimpeiro waitermouweiha thëpë kiri yaro, pihimoyamirayoma yaro, ihhi thëãha. Napëpëni urihi xamiamaiwei thë peximaimihe. Kua yaro ya pihikuwei thë kua: yanomamipëni napëe governo pë peximaimaoweiha thë ã pree kua, iht thë kua yaro urihinoamaiwei thëã pree kua inaha Davi Kopenawa kamae moyamipihikupënaha thëã pree kua

Thëã oxeowi ya hirimai pihio: yanomami thëpë, komi kutarenaha ai yanomami thëpë, yanotute thainomihtowehei, urihi xaaripramaiwei, yanomamipëni napëpë pihixariruwi, governo Estado peximaimaowehei. 


\section{Notas ortográficas}

No texto, utilizo vários termos em Yanomami, adoto a postura de oferecer alguma tradução acompanhando o termo avulso em Yanomami. Geralmente adoto a precedência do seu significado aproximado em português, seguido do termo na língua. As línguas Yanomami são distintas e recorrem inclusive a grafias distintas. Ofereço abaixo algumas orientações para facilitar a pronúncia dos termos utilizados.

A atual classificação linguística divide a família Yanomami em cinco línguas: Yanomae, Yanomamö, Ninam, Sanöma e Yaroami. O Yanomae é a língua principal por mim utilizada. Dentre as diferenças do português estão a existência de mais vogais: além de a, e, i, o, u, utilizamos o 'ẹ,' cuja pronúncia gravita entre 'e' e 'o': a sonoridade lembra 'i' na palavra 'dirty' em inglês; outra vogal é o ' $\mathfrak{t}$ ', com pronúncia algo entre o i e o u, similar a quando utilizamos o ö, na língua alemã. Aliás, nos dialetos sanöma, essa é a letra utilizada, com a mesma pronúncia.

Sobre as consoantes, há uma tolerância, causando indistinção dentre alguns caracteres: o 'p' pode ter som de 'p' ou 'b'; o 't' pode ter som de 'd', também; o 'th' sempre terá um som de 't' com uma leve aspirada, 'tha'. O 's'é sempre lido como se houvessem dois 'ss', nunca com som de ' $z$ '; o ' $r$ ' pode tornar-se ' $l$ ', sendo que no início de uma palavra, lê-se como pronunciamos no português no meio de uma palavra. "Rasasi" (pupunheira) leremos “Lassassi”" ou com o 'R' pronunciado em "cara". O 'h'é sempre aspirado, possui o som do 'r' inicial ou do 'rr'. O 'y' pode possuir som de 'dj' ou até 's'ou 'z' no caso dos sanöma e dos ninam.

Todas as traduções encontradas nessa tese são do Autor, qualquer erro, equívoco ou imprecisão são de minha responsabilidade. 


\section{Índice de figuras}

Figura 1: mapa da Terra Indígena Yanomami, com as áreas citadas nos capítulos 1, 2 e 3. As clareiras estão divididas em pontos no tempo cronológico de sete anos, com janelas de 2 anos.

Figura 2: Yanomami observa mapa com propostas de demarcação da Terra Yanomami, enquanto Carlo Zacquini conta a História da demarcação. V curso de Formação em 2005 na Casa de cura, Hekura Yano, Boa Vista -RR

Figura 3 Mapa das Terras Indígenas do Lavrado de Roraima, campos naturais (representado por tons rosados); destaque para a Raposa/Serra do Sol (1700mil hectares), a São Marcos e a Terra Yanomami, únicas que não foram demarcadas em ilhas

Figura 4: Terra Indígena Yanomami Ajarani: no eixo da BR 210 desmates provocados pelos pecuaristas que concentraram as terras provenientes de invasões da área demarcada. Contexto com Caracaraí e assentamentos, 1975(construção da BR210) e hoje (2016) Evolução histórica das alterações; anos de 1987, 1995, 2003 e 2016.

Figura 5: Mapa da região do Parawau na Terra Indígena Yanomami, incluindo as cabeceiras do Rio Demini, onde está a cachoeira "Xamatua" (Tamanduá) e em suas proximidades, as concentrações de jatobazeiros arokohi (Hymenea sp.).

Figura 6: Mapa indicando a região com as ocorrências de árvores citadas no texto, desde o Homoxi, passando pelas cabeceiroas do Rio Orinoco, na Venezuela, e ao Toototopi e Parawau, nas terras Baixas do Amazonas Brasileiro. 48

Figura 7 evolução histórica das clareiras a partir de 1975, cerca de dez anos de instalação missionária, a pista ainda de chão e os Yekuana na mesma margem do rio; imagem Landsat 1 MSS pixel de 80m. 1988, com a pista já construída e os Yekuana já em Fuduaduinha, do outro lado do rio; 1995 mostra menor desenvolvimento de roças, e a linha de transmissão para a usina hidrelétrica, construída com mão de obra indígena (ambas imagem Landsat TM5 resolução espacial de 30m.). Por fim imagem de 2015 Landsat 8 com 5m de resolução espacial, com a pista e as instalações em destaque. E o mapa resultante, com a abertura de clareiras conforme as épocas citadas.

Figura 8 roça de Chileno, com seu fiho carregando milho sinomo, e tabaco pini, sobre um tronco caído. Vemos também cultivares de banana, associadas a outras plantas, imitando a diversidade da floresta.

Figura 9: disposição das roças de Chileno no contexto da região de Auaris, pista de 
pouso e Rio Auaris (Asikamatu). A pista, com 1200m de comprimento pode servir de escala.

Figura 10: mapa das movimentações no Toototopi dentre 1987 e 2009, com as localidades citadas no texto. Os nomes duplicados indicam a permanência do grupo no mesmo local durante mais de uma temporada de análise. E sobre as setas está indicado o ano aproximado da mudança.

Figura 11: dois aspectos da região do Sinatha, a primeira a queda d'água logo a jusante do antigo sítio da comunidade e a segunda, a cena da entrada da comunidade pelo caminho de acesso à água.

Figura 12: Sinatha, segunda residência dos Apiahiki theri, a cerca de $4 \mathrm{~km}$ da antiga moradia que os denominavam. Outrora cercado de roças, hoje encontra-se cercado de áreas regeneradas. A construção é uma habitação coletiva redonda, com palha de ubim paahanaki (Geonoma guianensis) e abertura no pátio central, e vertendo suas águas para fora. 94

Figura 13: Marauiá movimento dos principais grupos habitantes, Os anos de deslocamento acompanham as trajetórias.

Figura 14: Rio Marauiá mostrando as moradas do povo Ironasi teripë; ao sul da imagem, o Rio Negro, e a cidade de Santa Isabel da do Rio Negro, demonstrando o quão próximo da morada atual, Bicho Açu.

Figura 15 Terra Indígena Yanomami rotas e movimentos no tempo do grupo Pohoroa; aí se registram algumas separações e movimento pendular de Xitipapuei e Pohoro 113

Figura 16: Fac-símile de mapa desenhado a mão por Daniel, Professor do Raita, sobre a região e os acessos utilizados para caça e procura de alimentos, sendo opções de caminhos.

Figura 17: Mapa da região do Alto Mucajaí, Homoxi, e as trajetórias migratórias de suas populações 128

Figura 18: imagem de satélite Landsat 5 TM de 1988 com a região do Homoxi, cabeceiras do Rio Mucajaí. 128

Figura 19: imagem de satélite Landsat 5 TM de 1993 com a região do Homoxi, cabeceiras do Rio Mucajaí.

Figura 20 imagem de satélite Landsat 5 TM de 1994 com a região do Homoxi, cabeceiras do Rio Mucajaí. 130

Figura 21 imagem de satélite Landsat 5 TM de 1996 com a região do Homoxi, cabeceiras do Rio Mucajaí.

Figura 22 .:imagem de satélite Landsat 5 TM de 1999 com a região do Homoxi, 
cabeceiras do Rio Mucajaí.

Figura 23.:imagem de satélite Landsat 5 TM de 2008 com a região do Homoxi, cabeceiras do Rio Mucajaí.

Figura 24:imagem de satélite Landsat 5 TM de 2016 com a região do Homoxi, cabeceiras do Rio Mucajaí.

Figura 25: :imagem de satélite Landsat 5 TM de 1986 com a região do Homoxi, cabeceiras do Rio Mucajaí.

Figura 26: imagem de satélite Landsat 5 TM de 1988 com a região do Homoxi, cabeceiras do Rio Mucajaí.

Figura 27: imagem de satélite Landsat 5 TM de 1993 com a região do Homoxi, cabeceiras do Rio Mucajaí.

Figura 28 imagem de satélite Landsat 5 TM de 1993 com a região do Homoxi, Brasil e fronteira com a Bacia do Rio Orinoco, Venezuela.

Figura 29: imagem de satélite Landsat 5 TM de 1999 com a região do Homoxi, na Bacia do Rio Orinoco, Venezuela 136

Figura 30: imagem de satélite Landsat 5 TM de 2008 com a região do Homoxi, na Bacia do Rio Orinoco, Venezuela.

Figura 31: : imagem de satélite Landsat 5 TM de 2016 com a região do Homoxi, na Bacia do Rio Orinoco, Venezuela

Figura 32: Mapa da região do Homoxi e suas habitações na Venezuela, indicando com nome em amarelo as comunidades com as quais mantinha relações de inimizades entre 20022005

Figura 33: Localidade atualmente ocupada pelos Moxihatetema em 1988, demonstrando ausência de qualquer ocupação.

Figura 34: Imagem de 1995 demonstrando não haver ocupação na mesma área 157

Figura 35: Imagem Landsat de fevereiro de 2007. época de abertura de roças (período de secas) cobrindo a mesma area das figuras anteriores: note o conjunto de clareiras indicando a abertura de roças na localidade.

Figura 36 Evolução da paisagem alterada de clareiras, com a área em produção e novas pequenas aberturas, como continuidade do processo de produção de roças em outubro de 2008. Nuvens atravessam a imagem em direção noroeste sudeste, mais uma nuvem e sua sombra.

Figura 37 Imagem Landsat de 2009, a mesma localidade apresenta as roças já maduras, novas aberturas e uma pequena clareira a nordeste que corresponde à localização da então 
casa dos Moxihatetema 158

Figura 38: Gráfico com a evolução da área de clareiras durante os anos de moradia na atual região dos Moxihatetema. Não foram analisados dados em 2010, portanto trata-se de uma projeção.

Figura 39: Situação geográfica da comunidade isolada Moxihatetema, em relação a outros grupos Yanomami; não há notícias de relações intercomunitárias deles com nenhum desses grupos vizinhos. 160

Figura 40: foto aérea oblíqua da casa dos Moxihatetemapë, em 2016, nas proximidades das cabeceiras do Ig. Prainha, Uxiora; foto de Guilherme Gnipper, 2016/Hutukara. 164

Figura 41 Localização dos Moxihatetemapë em 2000 a 2004(Landsat 5TM) e de 2014 a 2017(Landsat 8 com banda 8). Na imagem de 2001, a direita e acima (nordeste) notamos um ponto vermelho, indicando abertura de clareira recente, na imagem de 2003 essa mesma clareira encontra-se madura, com roças. Na imagem de 2014, há três pequenas clareiras, indicando a nova ocupação, situação que se repete na imagem de 2017; embora com nuvens é possível perceber as aberturas e até a formação oval / circular das residências nanahi, na imagem em preto e branco, de maior resolução (15metros). A distância dentre as posições é de $3 \mathrm{~km}$ aproximadamente. As linhas em azul apontam as direções de onde vieram, com as datas prováveis.

Figura 42 fac-símile de agenda "Boas Notícias", de 1985, época da luta pela redemocratização do país. Note o destaque dado à Demarcação das Terras indígenas. 183 


\section{Sumário}

INTRODUÇÃO

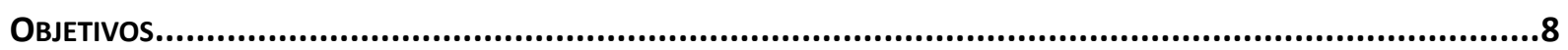

1. ESTADO NACIONAL COMO OBJETO DE CONHECIMENTO DAS SOCIEDADES RESISTENTES AO

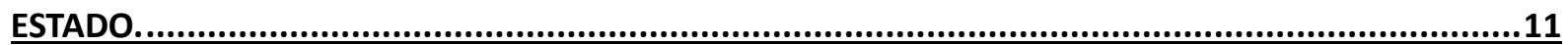

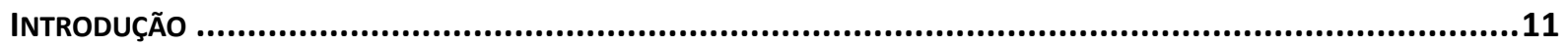

QUEM SÃO OS YANOMAMI E SUA ORGANIZAÇÃO SOCIAL (A POPULAÇÃO COMO OBJETO). ...................................... 13

UMa EtNografia da SOCIedade de Estado, Pelos Yanomami (LA ChUte du CIel). ..................................19

ESFORÇOS DO PEI NA CONSTRUÇÃO DE UM CONHECIMENTO SOBRE O ESTADO …............................................. 21

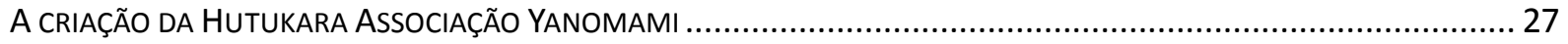

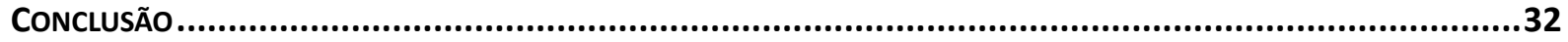

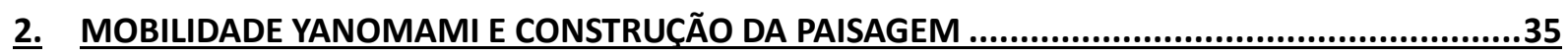

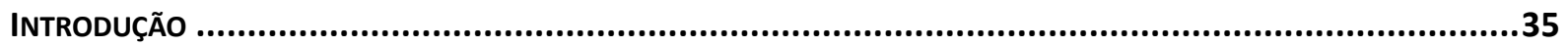

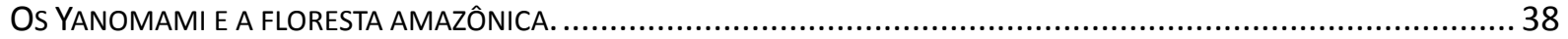

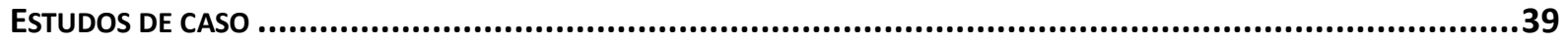

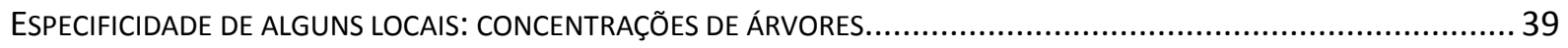

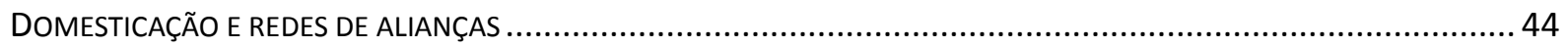

AWARIS: SOBRE FOME, ROÇAS E APROVEITAMENTO TERRITORIAL PELOS SANÖMA............................................. 48

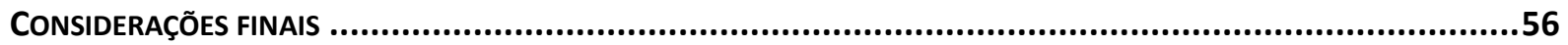

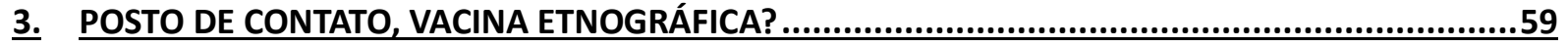

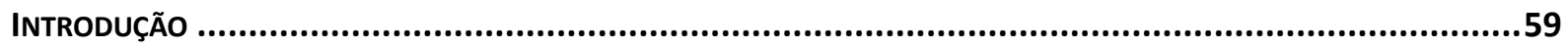

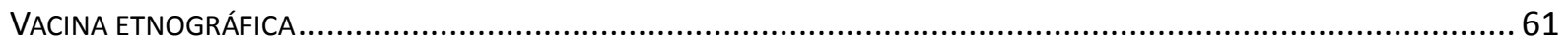

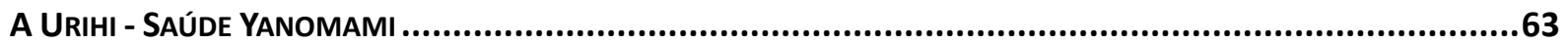

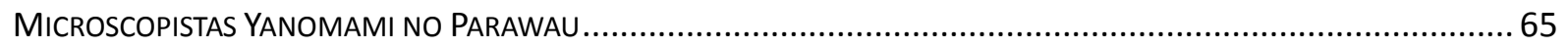

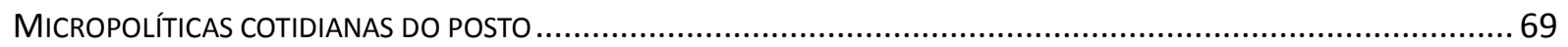

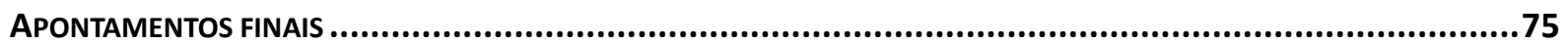

4. MOBILIDADE YANOMAMI E POLÍTICA INTERCOMUNITÁRIA: ACORDOS TERRITORIAIS NO

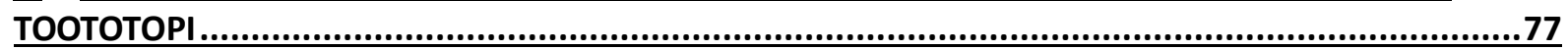

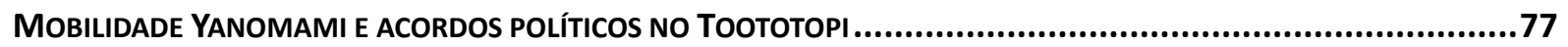

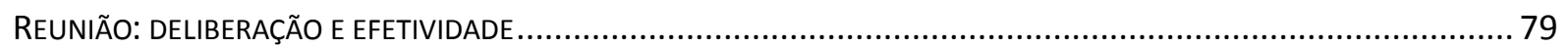

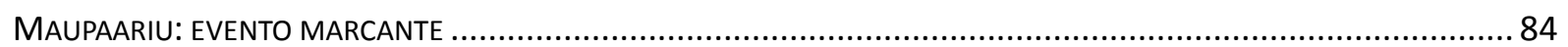

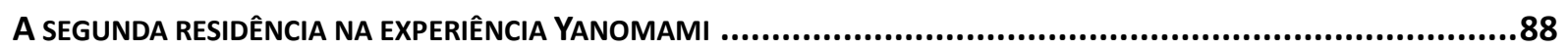

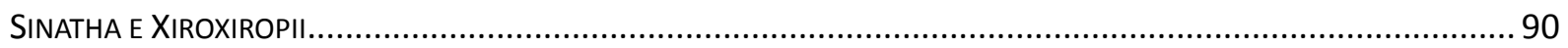


5. MOBILIDADE YANOMAMI NO MARAUIÁ: O CAMINHAR COMO 'ETHOS'. 107

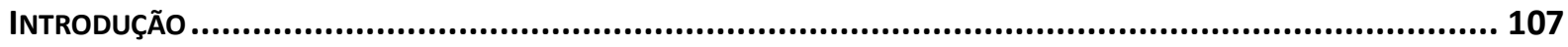

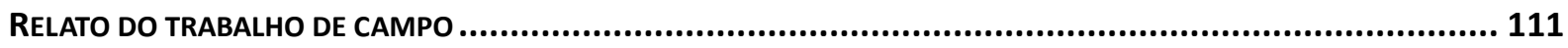

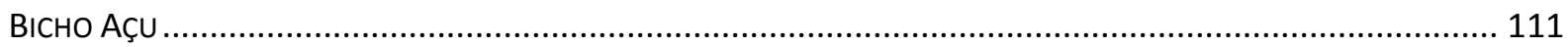

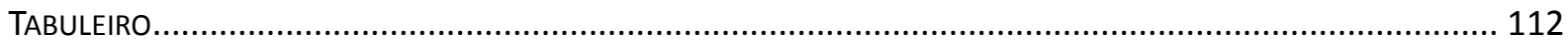

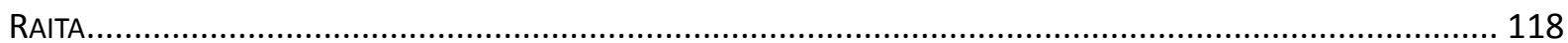

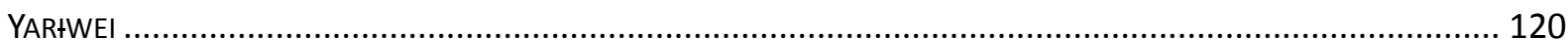

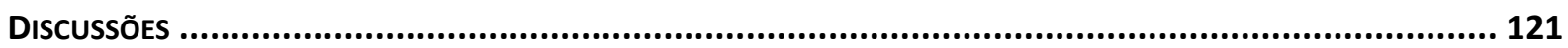

6. DO PARTICULAR AO ARTICULAR: YANOMAMI DO HOMOXI FRENTE ÀS FLORESTAS

DEGRADADAS PELA CORRIDA DO OURO (1987-1998 E 2013- PRESENTE)................................ 127

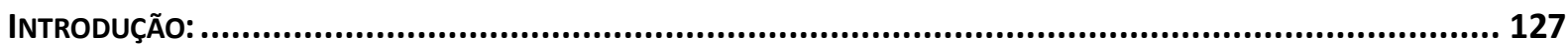

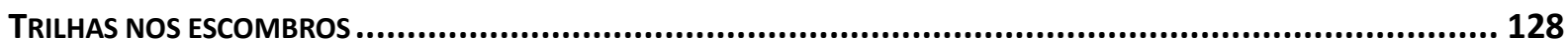

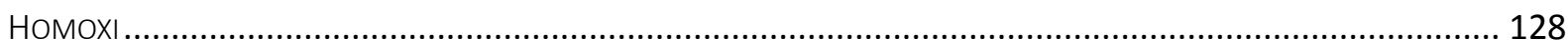

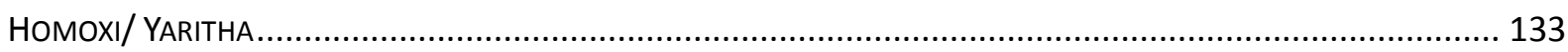

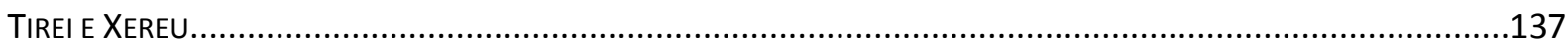

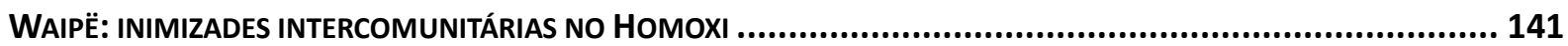

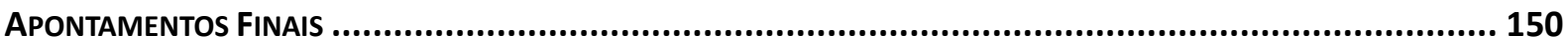

7. YANOMAMI ISOLADOS: A INTELIGÊNCIA GEOGRÁFICA DOS MOXIHATETEMA COM BASE EM

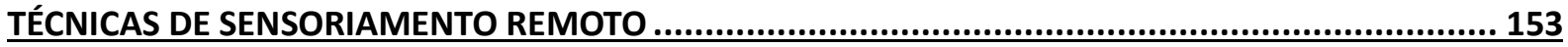

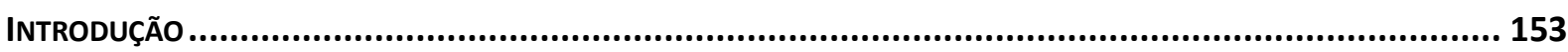

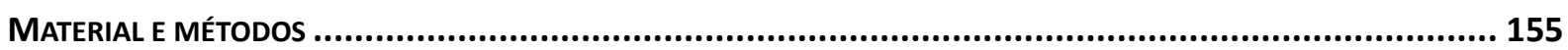

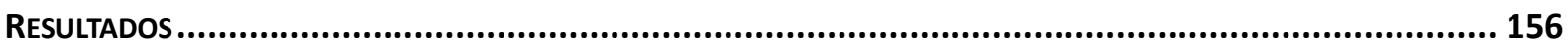

CONCLUSÃO

8. O ESTADO COMO ELEMENTO DIACRÍTICO: SEM OU CONTRA? O NÃO ESTADO COMO AUSÊNCIA

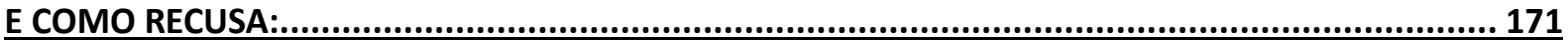

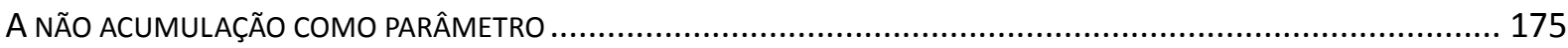

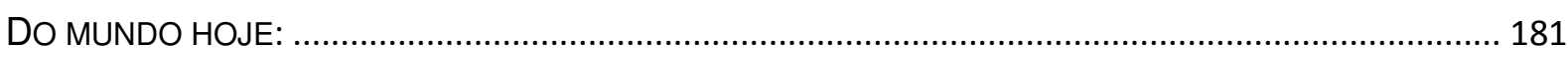

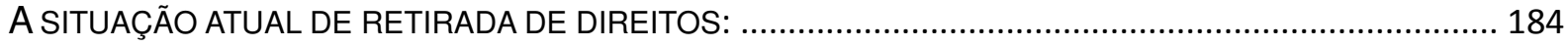

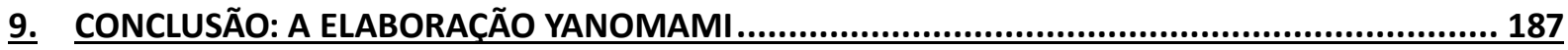

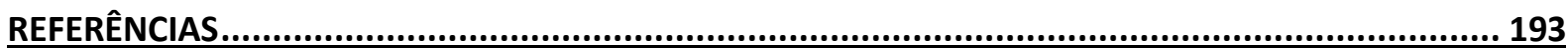





\section{Introdução}

Durante meu mestrado estudei a mobilidade Yanomami e seu efeito na paisagem florestal, numa perspectiva ecossistêmica; novos trabalhos em arqueologia amazônica trouxeram uma possibilidade de reinterpretar a ocupação indígena da Amazônia, e sua contribuição na constituição da floresta atual. O conhecimento sobre o povoamento ancestral da Amazonia indica que havia uma presença marcante à beira dos grandes rios, interrompida no século XVI, provavelmente pela chegada de epidemias com as quais não tinham contato (BUSH; SILMAN, 2007). Os estudos arqueológicos, etnológicos e ecológicos, em colaboração, indicam alterações na estrutura dos solos, na composição de espécies e movimentações de solo realizados pelas sociedades pré-colombianas, ampliando campos de estudo na compreensão da presença humana na Amazônia (CLEMENT; DENEVAN et al., 2015). O meu estudo com os Yanomami, uma sociedade norte amazônica de recente contato, com domínio de um território contínuo onde seus membros exercem uma mobilidade frequente, procura elucidar algumas questões sobre sua contribuição para a dinâmica ecológica da floresta, nos processos de sua renovação e no mosaico que dela resulta.

Tais sociedades foram vistas principalmente por aquilo que não tinham: não tinha organização em poder central (Estado), não possuíam tecnologia capaz de produzir grandes alterações, e a floresta onde vivem é ainda vista muito mais pelas suas limitações ecológicas e dificuldades ao povoamento, a despeito da imensa biodiversidade já reconhecida. Estudar a dinâmica de clareiras que se abrem e se regeneram, numa dinâmica de distúrbios de porte intermediário, poderia ser uma boa maneira de evidenciar indícios sobre a dinâmica na paisagem provocada pelas culturas indígenas, e sua contribuição na formação do ecossistema, melhor compreendido no contexto de estudos de ecologia histórica (BALÉE, 1994; 2013).

Dotado de informações relativamente precisas dos locais de moradia da maioria das comunidades Yanomami, de seus grupos populacionais ${ }^{1}$ (oriundas do meu próprio

1 Grupo populacional é um artifício para descrever apenas uma realidade empírica, expressa pela cadeia histórica de topônimos, a que uma dada população ocupa geograficamente num dado tempo, 
trabalho de coleta de pontos de GPS e sistematização de outros), detectamos a manutenção do sistema de mobilidade para os últimos 21 anos (1987-2009), descrevemos alguns padrões que estas seguiam, e por fim, analisamos a regeneração das clareiras não mais utilizadas como roça, utilizando da interpretação de imagens de satélite multitemporais, focadas principalmente em quatro pontos no tempo, com um intervalo regular de cerca de sete anos, (dado o tempo usual descrito na literatura do ciclo de roças e clareiras Yanomami). A mobilidade implica em condição para a regeneração da floresta, segundo o estudo, e sugere sua importância na própria composição da floresta, pois a escala de distúrbio causado por ela é compatível com o distúrbio intermediário, conforme Connel (1978) define, e Balée se inspira para definir as culturas indígenas como "culturas de distúrbio", do ponto de vista ecológico, realçando sua participação na construção da floresta habitada.

Os resultados deste trabalho sobre a mobilidade Yanomami somam-se a esse conjunto de evidências arqueológicas e etnoecológicas, que buscam modificar as concepções sobre o povoamento ameríndio na Amazônia. Clement et al (2015) sintetiza em mapas parte dessas evidências, incluindo modificações no ambiente (geoglifos, modificações de nível de superfície, montículos no Amapá, solos antropogênicos), dispersão e modificação de espécies e cultivares (caso da pupunha Bactris gasipaes, da castanha Bertholetia excelsa etc), reestimativas populacionais em função das novas descobertas. As implicações dessa mudança de paradigma sobre o povoamento na Amazônia estão ainda por serem reveladas, podendo modificar significativamente nosso modo de pensar a importância dos povos indígenas..

O estudo desenvolvido no mestrado contribui também por evidenciar uma continuidade de processo de mobilidade mesmo sob a nova realidade espacial com o estabelecimento dos postos de contato. Os postos de contato, missões religiosas ou os estatais, tornaram-se necessários pelo risco iminente de epidemias que resultam do seu efeito geográfico na paisagem (evitando o conceito de Chagnon "blocos de população", por estar associado a uma errônea idéia de linhagem, e mais afeito ao conceito de grupos de alianças intercomunitárias, de Albert). 
contato com a sociedade envolvente. Enquanto realidade necessária para prover serviços básicos de saúde, isso implica numa potencial transformação da dinâmica espacial yanomami, pelo afluxo de utensílios manufaturados, cobiçados devido a sua raridade, pelos serviços etc. A não necessária a fixação ao posto evidencia o vigor dos processos de mobilidade característicos do modo de vida Yanomami. A mobilidade merece atenção por contribuir no incremento de biodiversidade e nos processos de renovação da floresta, conforme direcionada pelo modo de vida e de pensar Yanomami.

Em meu projeto de tese de doutorado, há uma continuidade aos estudos de mobilidade tentando compreender as elaborações teóricas dos Yanomami a respeito da própria mobilidade, se haveria alguma evidência de tal efeito ecossistêmico ser deliberado por parte de seus causadores. Essas afirmações de caráter ecológico não devem encontrar ressonância direta com o modo de pensar Yanomami. Deve-se busca-la na práxis, no viver dos Yanomami, desfrutando de uma floresta e dos ambientes ali criados pela abertura de uma clareira para roça, numa política de habitar. Considerando a constituição de pequenos grupos em movimento realizando um modo de habitar bastante similar, e onde as relações entre as pessoas e as coisas constituem assunto central de debate e motor dos relacionamentos, numa relação propriamente cosmopolítica, está posto como objeto de estudo uma relação possível entre essa política do habitar e seu resultado ecossistêmico.

A mobilidade, as trajetórias de cada grupo é assunto relativamente comum de se conversar com os Yanomami, como se fosse naturalizada em seu modo de vida; tornar-seia difícil colocar uma reflexão sobre sua mobilidade, característica a ser melhor percebida em contraste com nosso sedentarismo, ao ser colocado à frente de uma sociedade que tem na fixação a sua produção do espaço. Desta forma, apenas a possibilidade de ver-se diante de um outro sistema, uma outra estrutura de ação, poderia leva-los a refletir sobre o seu próprio sistema. A intenção de aproveitar a reflexão, ainda incipiente nos postos de contato para me perguntar: que reflexões fazem os Yanomami a respeito dessa alteridade, e que práticas territoriais se travam perante as possibilidades dadas e os devires históricos definidos por uma situação intercultural ${ }^{2}$ cada vez mais permanente?

2 Utilizo "intercultural" quase como sinônimo de "relação de contato com uma sociedade diferente", na maioria das vezes, a nossa; 
As situações interculturais funcionam tal como Jose Antonio Kelly Luciani empresta da dinâmica de motores sob a ótica da engenharia ${ }^{3}$ : conhecemos o comportamento de um sistema em sua reação a perturbações. Pensar nos Yanomami e suas situações de contato cada vez mais frequentes com as sociedades de Estado, em situação de fronteira, e sobre como lidar com o mundo novo representado pelos espaços produzidos pelos não Yanomami. Sobretudo enquanto representativos de sociedades complexas em cujo elemento diacrítico principal está a organização hierárquica principal do Estado, vindo a refletir inclusive em sua arquitetura, em sua produção do espaço (LEFEBVRE, 1991).

Um desenvolvimento teórico mais profundo se faz necessário para entender a sociedade de Estado. De certa forma, o programa educativo ao qual eu participei (Programa de Educação Intercultural Yanomami - PEI) contribuiu para formar parte da atual diretoria da Hutukara Associação Yanomami. O PEI é um projeto de Davi Kopenawa desde a concepção dessa formação. Os professores formados ou participantes puderam adquirir experiência para pensar a interculturalidade na qual os Yanomami estão crescentemente envolvidos.

A obra de Bruce Albert é fundamental para a construção desse trabalho, em sua tese (ALBERT, 1985) desvenda como a morte, a doença determinam as alianças e rivalidades entre os Yanomami. Albert contesta o modelo em que tanto Chagnon, seguido por Lizot, afirmam que a descendência, através de grupos de linhagem local, definem a organização social Yanomami. Esse modelo de parentesco, com inspiração em estudos africanistas, onde a linhagem apresenta grande importância, não tinha evidências claras para os Yanomami. E mostra que a rede de relações genealógicas empíricas que os Yanomami traçam, num intervalo de até 150 anos, por si só, seria um argumento muito frágil para sustentar uma significância da linhagem. Embora seja evidente que a cadeia de sítios de morada encontre ressonância para os Yanomami, resultando numa cadeia toponímica que eles são capazes de remontar por um longo período, indicando os velhos locais de moradia, elas não estão necessariamente ligados a uma genealogia, pois não apresenta nome algum. Os Yanomami, já era sabido, não pronunciam os nomes de seus parentes,

3 Em comunicação pessoal aula de Etnologia Indígena, por uma teoria da mudança e da mestiçagem, na UFSC, em maio de 2014. 
muito menos de seus mortos.

O sistema ritual e a organização social Yanomami se enquadra nas sociedades das terras baixas sul-americanas e caracteriza-se por uma ausência deliberada de poder central, perceptível mesmo numa pequena comunidade. A ausência de um sistema de linhagens orientando a organização social é coerente com a ausência de poder central.

Contribuições etnográficas como a de Bruce Albert permitiram reconhecer um outro tipo de coerência no pensamento ameríndio, inspirando novos paradigmas nos modos de compreensão científica; uma das correntes que se revelam, o perspectivismo ameríndio, e a chamada virada ontológica.

Viveiros de Castro (1996; 2002), em trabalho parceiro com Tania Stolze Lima, propõe o multinaturalismo, para uma cultura, revertendo o usual multiculturalismo (uma natureza, muitas culturas, sendo a primeira aquela estudada pela física). Já bastante conhecido, o método da equivocação controlada, cara ao problema da tradução, o perspectivismo foi inspirado no pensamento Yudja, exposto na tese de Stolze Lima (2005), em que afirmavam que os animais viam o mundo exatamente como os humanos mas em outra perspectiva, com várias implicações para o xamanismo, Viveiros de Castro (2015) imprime similar implicação para a filosofia, tratado em Metafísicas Canibais, em que ele propõe um diálogo com a obra de Deleuze e Guattari (1995; 2010 (1972)), que por sua vez teve evidente influência do que se conhecia das sociedades indígenas. Traz de volta a discussão de uma ciência com sujeito, onde haja uma valorização dos processos de singularização no interior das sociedades humanas.

Roy Wagner (1981) propõe que há uma dialética entre invenção e convenção na cultura, isso permitiria atualizações para o evento histórico, num processo inovador, e esse é cristalizado, tornando-se convenção. Elabora ainda sobre o papel do pesquisador, pois uma vez imerso na realidade de estudo, e focado a compreender o outro naquilo que o diferencia de si, "o antropólogo é obrigado a incluir a si mesmo e seu próprio modo de vida em seu objeto de estudo" (WAGNER 1981 p.28), de forma a ultrapassar os limites e convenções de sua própria cultura. Wagner percebe assim haver um esforço em sentido contrário, de os nativos, objeto de estudo dos antropólogos igualmente estudarem seus 
pesquisadores, o que ele denomina de antropologia reversa. Estou nesse trabalho atento à forma como os Yanomami investigam e decifram nossa sociedade. como 'etnografam' o napë, esse 'contra', conceito adotado para se referir aos não Yanomami.

As duas linhas científicas em questão nessa tese, enquanto desconstrutoras de paradigmas, são concomitantes: enquanto no campo ecológico temos a ecologia histórica, no campo político temos uma sociedade orientada horizontalmente, indicando intencionalidade no fato. Essa concomitância pode significar um nexo, uma indissociabilidade entre esses aspectos das sociedades ameríndias das terras baixas.

Se esse novo paradigma emergente, combinando campos de conhecimento como a arqueologia, os estudos de agroecossistemas, a etnoecologia, apresenta uma outra compreensão das populações ameríndias, pode ser posto em diálogo com a organização social e a estrutura revelada por Bruce Albert, quando refuta a abordagem da descendência como motor dessa mesma organização social? A elaboração política Yanomami passa pelo desenho de sua territorialidade, seria de se supor de ela abarca-la, à sua maneira, do modo como vivem em relação ao espaço habitado.

Clastres (2003) afirma não se tratar de uma ausência mas de uma recusa, quando ele as define como Sociedades Contra o Estado. Questão a ser tratada nessa tese, esse conjunto de ausências pode derivar muito mais de nosso modo de entender do que admitir a ausência como explicação da paisagem amazônica e sua convivência com os povos indígenas, bem como sua organização social não verticalizada. Se uma organização social recusa o poder central e mantém uma ação coordenada e multiescalar de seus membros no lidar com a floresta da qual participam, não parece ser possível analisar os fenômenos em termos determinísticos e causais, mas muito mais de configurações, em colaboração ou concorrência.

Tal tarefa depende de investigação em campos simultâneos e sempre buscando evidências coerentes entre si: 1) na experiência Yanomami, através principalmente da obra de Bruce Albert (1985), do Pensamento de Davi Kopenawa (KOPENAWA; ALBERT 2015) e da pequena experiência etnográfica do Autor no Programa de Educação Intercultural e outras passagens entre 2000 e 2012. Nessa última, onde residem parte de 
meus dados primários, encontram-se depoimentos e atitudes a serem analisadas no conjunto desse trabalho. 2) na paisagem amazônica da Terra Yanomami, cujos dados organizados no sistema de informações geográficas permitem uma abordagem de processos de transformação da paisagem que podem ser imaginados para o conjunto da história milenar da presença indígena na Amazônia; e 3) ainda relacionado à minha pequena experiência etnográfica, mas com enfoque distinto, está a questão do contato intercultural com uma sociedade de Estado, de captar a experiência Yanomami em sua prospecção de compreender a alteridade caracterizada pela existência de hierarquia, de uma sociedade complexa, pelo Estado Nacional como modo de organização. A integração dessas vertentes de conhecimento pode oferecer um panorama distinto de entendimento da realidade. Integração essa que por razões de método pode ser um desafio ainda intangível, mas um primeiro passo nesse desafio pode ser dado por uma simetrização dos campos. A postura presencial, testemunhal, coloca uma outra vertente na própria constituição do estudo: partir de ferramentas diversas, um "objetivo" mapeamento feito de forma artesanal, com o não afastamento do "objeto" enquanto sujeito da pesquisa: o mapeamento objetiva revelar intencionalidades nas movimentações; a conjunção dessas, convergindo para uma tese comum. Sem apagar a dualidade, atenua-se assim seu contraste, parecendo compor um mesmo conjunto. Ao assumir o foco sobre a paisagem e o ato de habitar, ao mesmo tempo construindo paisagem, a adesão a esses conceitos é consequente com a busca de atenuação dos conceitos de natureza e cultura.

Os resultados indicam que os Yanomami desenvolvem estratégias espaciais perante diversos desafios, incluindo as limitações ambientais, a socialidade e utilizam também essa habilidade no lidar com o novo: o contato em suas diversas modalidades e com diversos grupos, tem na mobilidade uma opção a garantir certa distância quando conveniente. Apresento primeiro em campos distintos, a elaboração Yanomami perante ao contato com nossa sociedade, a construção da paisagem florestal e o posto de contato como locus de experienciação da alteridade. $O$ posto de contato torna-se uma possibilidade de convivência em vantagem numérica, permitindo o exercício etnográfico (às avessas). E segundo, focado na análise da mobilidade em algumas regiões, a mobilidade é relacionada à proximidade do posto e distanciamento, numa segunda residência; são relatados casos nas regiões do Toototopi, no Marauiá, descrevendo um movimento retromigratório e no Homoxi, mantendo sempre um povoamento próximo ao 
posto, enquanto a maioria se refugiou em regiões em condições sanitárias menos afetadas, na Venezuela. O fato de os Yanomami escolherem ocupar adjacências e não a clareira de roça pretérita, indica uma importância a esse espaço. Os dados de campo indicam haver uma estratégia espacial onde essas áreas entram como atratoras de fauna, as roças velhas em regeneração são locais preferenciais para caça de henimou (caçadas de maior duração para alimentar os convidados de uma cerimônia). A escala da paisagem possibilita elucidar uma experienciação ao nível dos sujeitos com as coisas, onde tais trajetórias e seus efeitos descritos podem ser compreendidos como uma inteligência espacial, pois os Yanomami buscam 'ler' os lugares, diagnosticar sua saúde enquanto sítio de moradia, para orientar a decisão de permanecer ou mudar. A soma dessas vertentes, ora ambientais e políticas, indicam haver um nexo, uma concomitância nesses processos inventivos: a) a inteligência ambiental, capaz de moldar a paisagem em colaboração com os outros seres vivos; as habilidades envolvidas nos afazeres na floresta; e b) a inteligência política Yanomami, especialmente a lidar com o novo.

Os capítulos presentes na tese são divididos em uma primeira parte, constituída de três capítulos, em que se apresentam 1)vertentes humanas da relação dos Yanomami na compreensão das sociedades de Estado Nacional; veremos aí como exercitam e se expressam num debate político em campo alienígena; 2) a construção da paisagem pelos Yanomami, alguns elementos dessa ecologia histórica e 3) no âmbito do posto, como se dão as micro-relações do contato quando a sociedade de Estado ainda é minoritária. E uma segunda parte, de quatro estudos de caso etnográficos/cartográficos, separadas em capítulos sobre regiões: 4) Toototopi, onde discuto as relações políticas inercomunitárias dos Yanomami com o posto, onde havia antes uma missão; descrevo aí movimentos pendulares de aproximação e afastamento. 5) Marauiá, onde o elemento centralizador das relações interculturais se dá pela via de acesso do rio; 6) Homoxi, onde a principal forma de contato foi o garimpo, deixando alterações na paisagem e as estratégias geográficas e sociopolíticoambientais dos Yanomami 7) Moxihatetema, um grupo resistente ao contato, mas marcado pela iminente presença do outro. Culminando para um capítulo conclusivo, em que a literatura teórica é discutida na tentativa de sintetizar uma conclusão.

\section{Objetivos}

Investigar uma possível relação interativa entre a mobilidade Yanomami e seus efeitos na floresta com o sistema ritual e político Yanomami descrito por Bruce Albert 
(1985) e determinante da própria mobilidade. Avaliar perante o momento presente, pós contato, a vitalidade desses processos que levam à mobilidade e à renovação da floresta na Terra Yanomami.

Descrever movimentação residencial dos Yanomami observáveis numa perspectiva de sensoriamento remoto e informações geográficas sistematizadas, buscando reconhecer possíveis padrões.

Analisar fragmentos de falas, conversas, depoimentos e discursos coletados no âmbito da experiência com o Programa de Educação Intercultural da CCPY (2001-2008). As falas preferenciais versam sobre: trajetórias de comunidades e pessoas; lutas e desafios políticos enfrentados; organização socioespacial, incluindo roças, afazeres cotidianos, habilidades relacionadas; o posto de contato, relações com os seus ocupantes, conflitantes ou não; habilidades do mundo napë.

Descrever e analisar afazeres cotidianos, sobretudo em trilhas, caminhadas e roças em seus diversos momentos do processo. Observar as habilidades envolvidas e as interações com outros seres reconhecidos pelos Yanomami durante as atividades. As habilidades aqui descritas podem serem ressignificadas para os novos desafios postos pelo contato.

Integrar dados e informações coletadas nos três processos acima, num esforço de síntese em que seja possível verificar/ testar alguma congruência entre o processo de mobilidade e seus efeitos na paisagem florestal e as deliberações políticas dos Yanomami, baseadas em seu sistema ritual e sua cosmopolítica. 

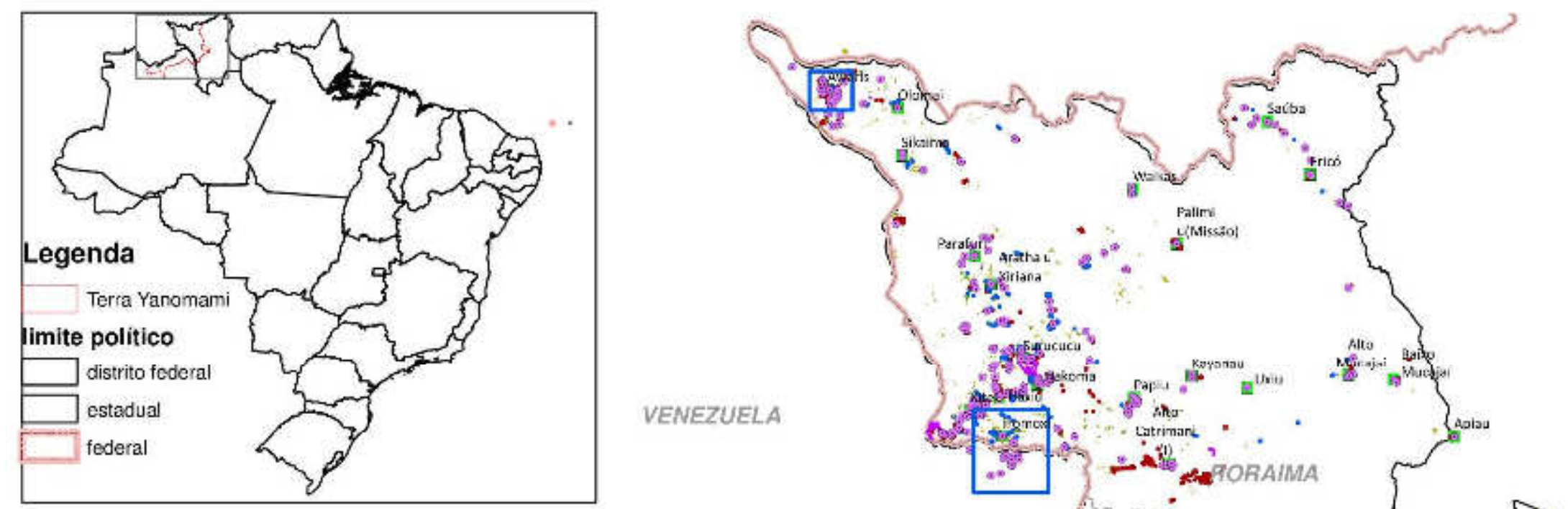

Figura 1: mapa da Terra Indígena Yanomami, com as áreas citadas nos capítulos 1, 2 e 3 . As clareiras estão divididas em pontos no tempo cronológico de sete anos, com janelas de

\section{Legenda}

- comunidades 2015

1 postos

\section{clareiras Yanomami}

\section{ÉPOCA}

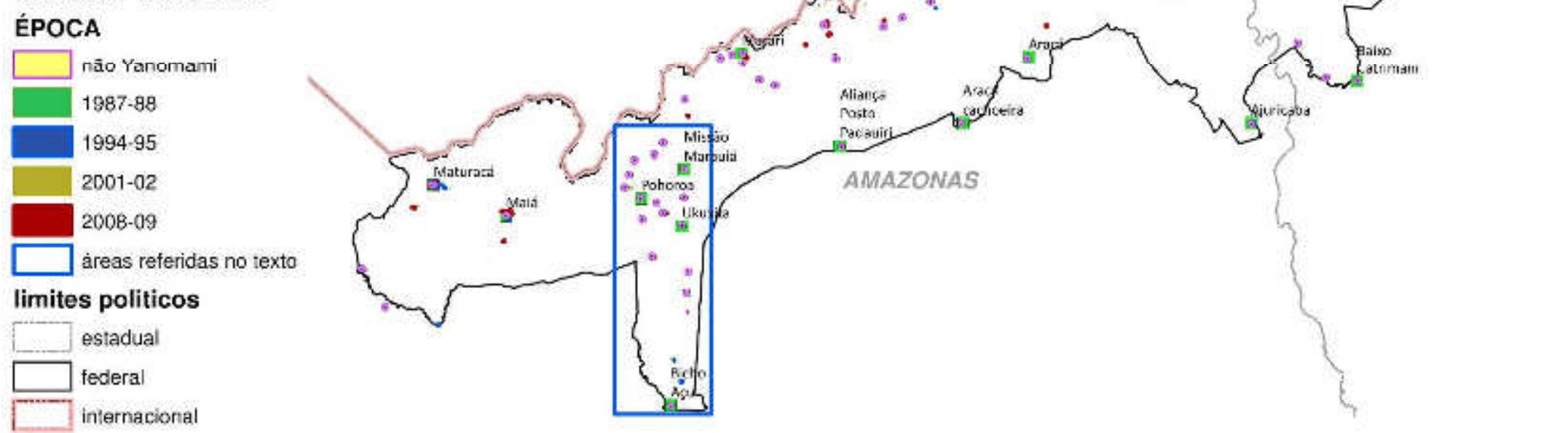




\section{Estado Nacional como objeto de conhecimento das sociedades resistentes ao Estado.}

\section{Introdução}

Este capítulo concentra-se em compreender melhor as relações dos Yanomami com a sociedade envolvente, de Estado. Justifica-se esse estudo porque esse é o contexto presente para os Yanomami hoje, o pós-contato, a consciência crescente da existência da alteridade. Albert (1992) lembra que àquela época, poucos etnólogos estruturalistas davam a atenção à História do contato, por mais marcante que ela tenha sido para os povos. Se hoje temos esse desafio já em andamento (ALBERT, 1997b, 2002; KOPENAWA; ALBERT, 2010), ainda cabe aprofundar no conhecimento sobre as sociedades de Estado. O Estado, enquanto poder centralizado, é o elemento diacrítico que nos diferencia das sociedades indígenas; considerando o mundo atual convém associá-lo ao poder econômico por ser este, em última instância o poder que protagoniza as ações num planeta cada vez mais globalizado (SANTOS, 2001; HARVEY, 2005); mais do que teorizar sobre ele, o esforço aqui foca em detectar como os Yanomami têm operado nos contextos e desafios que envolvem o contato com as sociedades de Estado.

Do ponto de vista metodológico trata-se de utilizar uma perspectiva invertida de direção de conhecimento: em abordar como se dá a percepção a partir da ótica dos Yanomami. Como não seria possível construir esse texto sem ser participante, esse trabalho assume essa condição para o Autor, de uma pesquisa diversa do distanciamento característico. Disso põe a necessidade de ter também como objeto de análise minha própria inserção, minha própria postura na relação cultural expondo claramente em como ela se norteou e quais as contribuições nessa busca, nessa investigação que os Yanomami realizam desde que conseguiram 'pacificar os brancos'4. Alguns Autores vêm desenvolvendo etnografias sobre os Yanomami em relação ao que pensam sobre essa alteridade representada por nós. Dentre os que desenvolveram trabalhos em contexto e experiência similar ao meu, cito Rogerio Do Pateo (2005), Silvia Guimarães (2005a; 2005b), Luis Fernando Pereira in memoriam (2007;

4

Referência ao nome do Livro de Bruce Albert e Alcida Ramos, pacificando o branco, que trabalha justamente com cosmologias do contato do norte Amazônico. 
2008), Gustavo Menezes (2010), Clarisse Jabur (2014), Ana Maria Antunes Machado (2015) e Corrado Dalmonego (2015).

Dessa forma, aqui se propõe um desafio, de fazer pesquisa estando envolvido com o objeto, como pesquisa participativa, numa tentativa, para a antropologia, de superar o relativismo cultural. Wagner (1981) propõe essa inversão de perspectiva, em que os 'nativos' tentam estudar os 'ocidentais': A começar por admitir a legitimidade desse esforço, e tratar tais tentativas reconhecendo a validade de seus métodos (LÉVI-STRAUSS, 1989). Alguns trabalhos têm sido feitos nesse esforço (ALBERT, 2002; KELLY, 2005).

Wagner (1981) conceitua como "Antropologia Reversa" o ato dos nossos 'objetos' de estudo ('os outros', os 'nativos') teorizando e fazendo reflexões sobre 'o modo de vida dos seus estudiosos'. Eu testemunhei essa atitude desde o início dos trabalhos com os Yanomami, na forma de um interesse em entender e interpretar cada categoria de napëpë (os 'contras', não Yanomami) que eles conheciam. Numa situação de contato como tal, a antropologia reversa torna-se uma necessidade, para se posicionarem perante o outro e suas intencionalidades, criar uma condição de defesa perante às ameaças que essa relação implica. A intencionalidade do outro se põe como questão central nessa abordagem, e o modo como esta atua, a atualizar processos próprios de compreensão do mundo.

Eleger a categoria de Estado, poder central, como recorte diferencial para nossa sociedade é por interpretar que a ideia de poder central traz uma série de aspectos relacionados ao controle social, e o fato de as pessoas, ao naturalizarem a ideia do 'governo', um governo que transcende a figura do Estado tal como o conhecemos (hoje falamos, por exemplo, em auto-governo). Interessa não apenas os grandes interesses de Estado, mas o 'Estado introjetado' nas pessoas, suas pequenas atitudes, discurso e modo de pensar. Modo de pensar inclui: tentativas de projetos para os Yanomami, do que eles deveriam ser/fazer; interdições, ações normativas recaindo sobre eles; maior atenção à riqueza territorial e à exploração possível, de preferência imediatista. As percepções e respostas às atitudes 'de Estado', detectadas nas pessoas, um comportamento fractal do Estado enquanto determinante do pensamento/comportamento das pessoas. Esse trabalho busca evidenciar que os Yanomami desenvolvem estratégias para lidar com o outro, nesse processo inventivo, são obrigados a gravitar nos dois campos culturais aqui diferenciados pelo Estado: ora atuam com protocolos da sociedade de Estado, e ora participam das dialogias com os Yanomami. Sempre tendo 
atenção ao fato de o Estado estar inextrincavelmente relacionado ao sistema capitalista de produção, determinador, em grande medida, do modo e dos interesses sobre a terra e o povo Yanomami. Tendo como premissa a interpretação clastreana de luta contra o um, e pensando na atualização de Sztutman (2011) de a sociedade contra o Estado, para os Yanomami, permanece válido o enunciado clastreano? Clastres foi original em perceber os povos ameríndios não aderiam a um poder central, não por desconhecimento, mas por conhece-lo, e recusarem aceitar suas consequências. Ouvi dos Yanomami deles já conhecerem os napëpë (referindo-se a nós, sociedades de Estado, não Yanomami) e optarem por seu próprio modo de habitar.

\section{Quem são os Yanomami e sua organização social (a população como objeto).}

Faço a seguir uma rápida exposição sobre quem são os Yanomami, dentro do que interessa a esse trabalho, a saber a sua organização sociopolítica; embora considere o manejo da paisagem como uma resistência também política, não entrarei nos assuntos ecológicos porque já foi trabalhado, com revisão bibliográfica pertinente e contribuições do Autor ${ }^{5}$ (NILSSON; FEARNSIDE 2011). A maior parte dessa contribuição é de Albert (1985).

Os Yanomami são habitantes das florestas e campos montanhosos do norte Amazônico, ocupando terras de dois Estados Nacionais: Brasil e Venezuela. Sendo um povo de contato recente, apenas nesse milênio se ampliou o contato permanente, ainda assim boa parcela mantém contato ínfimo, devido às longas distâncias. A comunidade, família ou conjunto de famílias estendidas, constitui a unidade política sobre a qual se organiza a sociedade, sendo que há um conjunto de comunidades vizinhas que formam um conjunto multi-comunitário, geralmente com alguma origem semelhante a partir de um certo momento histórico, mas com membros de comunidades remotas em sua composição, na condição de cunhados/genros ou pretendentes a se casar nesta.

Dentro da comunidade as questões cotidianas, o dia seguinte e suas atividades são decididas nos hereamou, discursos públicos que adentram o anoitecer. O início do anoitecer assume o palco de um parlamento político de todos os moradores da grande casa circular comunitária (yano). Aqueles que moram, por opção, em casas agregadas, também ouvem e respondem aos discursos proferidos no centro da casa xapono. A opção de falar é livre, é de quem tem algo a falar.

5 Ver capítulo 3, Mobilidade Yanomami e contrução da paisagem. 
As comunidades são pequenas, permitindo um consenso maior, ou que as tensões comumente existentes não sejam tão intensas que inviabilize a convivência. Nesse caso, uma secessão abre a possibilidade de uma nova comunidade se formar. A família descontente se muda, faz uma nova roça e iniciam uma nova comunidade. O conjunto multi-comunitário guarda um certo parentesco entre si, em última instância, nem ele resolve a necessidade dos matrimônios. As uniões ideais seriam prescritivas e se dariam entre primos, mas essa possibilidade se esgota e a exogamia torna-se a regra. A exogamia enquanto parâmetro de continuidade e perpetuação de cada comunidade em particular desenha uma rede de relações onde o processo de mobilidade espacial é condição, e caracteriza a vida dos Yanomami. É comum encontrar pessoas de aldeias distantes, habitando e já estabelecidas numa outra região.

Essa tensão entre a rede de relações e a soberania política da comunidade atomizada foi objeto de discussões no meio antropológico sobre o norte Amazônico (RIVIÈRE, 1983-84; RIVIÈRE, 1984; BARBOSA, 2002; RIVIÈRE; GRUPIONI et al., 2007). Isso marca a existência de uma "alteridade necessária", em que alternamos a visão política da comunidade auto-suficiente e atomizada e da grande rede de relações com o outro. No estabelecimento dessas alianças inter-comunitárias, outros diálogos cerimoniais se estabelecem e desenham a situação política de cada comunidade, marcando mesmo toda a reflexão sobre a doença, a morte, sempre imputada por um outro Yanomami, um agente externo. Disso derivam as acusações de feitiçarias gerando inimizades muitas vezes entre comunidades que antes eram amistosas.

Os Yanomami, embora vistos como um único povo pelas suas características, possuem diferenças internas, tanto linguísticas, como na cultura material; os terrenos por eles ocupados se extendem de áreas montanhosas do Planalto Parima, às terras baixas das bacias dos rios da margem direita do Rio Branco, em Roraima, bem como da margem esquerda do Rio Negro, no Amazonas. O contato com a sociedade nacional brasileira se deu por diversas frentes e formas, dada a extensa terra que ocupam (9,66 milhões de hectares só no Brasil); podemos elencar essencialmente as seguintes: missões evangélicas e católicas, frentes de ribeirinhos em busca de recursos florestais, agentes de Estado (indigenistas, comissões de limites, profissionais de saúde etc), trabalhadores da Rodovia Perimetral Norte (BR-210, na década de 1970), colonos agrícolas e fazendeiros pecuaristas no leste da terra, garimpeiros e faiscadores de ouro. Estes últimos historicamente provocaram o maior impacto, sem olvidar que as 
epidemias por eles trazidas chegavam antes mesmo de muitos contatos físicos.

O processo de contato entre esses dois modos de viver e pensar se deu num momento em que nossa ciência se via em franco questionamento quanto ao seu papel, na dominação colonial e mesmo da própria ciência, em crise com seu próprio etnocentrismo (LATOUR, 1994; ALBERT, 1995). A possibilidade de extinção total da população autóctone brasileira era prognosticada por Darcy Ribeiro, levando-o a propor um acordo entre Governo brasileiro e o Summer Institute of Linguistics (SIL) de através de missões evangélicas norte americanas, fazer o contato com povos isolados para que se preservassem pelo menos as línguas indígenas, que seriam aprendidas por esses linguistas-missionários para assim traduzir a bíblia para essas línguas. Parte dos contatos de nossa sociedade com os Yanomami foi feito através desse processo, os Sanöma (Borgman et al.) os Ninam (Migliazza) os Yanomami de Surucucu, Papiu e posteriormente do Mucajaí, com quem permaneceram (Unevangelized Fields Mission - UFM que se tornou a "Missões Evangélicas da Amazônia", MEVA) e no Aracá e Toototopi (a "New Tribes Mission", que se tornou a "Missão Novas Tribos"), onde vivia Davi Kopenawa (KOPENAWA; ALBERT 2015), àquela época um jovem que já havia perdido sua família original no processo do contato, sempre causador de choques epidemiológicos devastadores para as populações autóctones (RIBEIRO 1956). A epidemia xawara é um elemento central na investigação que os Yanomami fazem dos napëpë. Em todos os depoimentos de história do contato coletados também há episódios devastadores de contração de epidemias.

A trajetória de Davi, recém contada em biografia (KOPENAWA; ALBERT 2015), testemunha quase todos os modos em que o contato ocorreu. Tendo sido o Yanomami mais proeminente na defesa de sua terra (ou da terra a que pertence, numa leitura original de Maria Rita $\mathrm{Kehl}^{6}$ ), Davi teve a oportunidade de 'conhecer o mundo dos brancos' de forma bastante abrangente. O co-autor de seu livro, Bruce Albert, foi, junto com Claudia Andujar, Carlo Zacquini e Alcida Ramos, um dos primeiros grandes parceiros no projeto de defesa da terra, com a constituição da Comissão pela Criação do Parque Yanomami (CCPY), organização que teve papel proeminente nessa luta e na intermediação dos direitos dos Yanomami frente ao Estado Nacional. Essa história já está contada, não apenas no livro A Queda do Céu (2015), mas em outros (LE TOURNEAU, 2010) e também pela coletânea de notícias de imprensa da

6 Maria Rita Kehl O fio que dá sentido à vida Publicado na Folha de São Paulo, Ilustríssima em 24 de novembro de 2013. 
coleção “povos indígenas do Brasil” (RICARDO, 1984, 1991, 2001, 2006) e da construção dos arquivos da CCPY. A Queda do Céu (KOPENAWA; ALBERT 2015), tem a originalidade de conta-la na perspectiva do Yanomami Davi Kopenawa. A aclamação do livro nos meios indigenistas indica a legitimação de um saber a ser devidamente reconhecido, a cosmologia Yanomami: embora encontre reconhecimento perante a lógica relativista, como 'produto de uma cultura', é interessante perceber sua eficácia no encadeamento com a crise ecológica e sanitária a que foram submetidos os Yanomami, com o contato, e as respostas advindas dos saberes xamânicos, plenamente mobilizados na luta de Davi. O modo como foi produzido alcançou grande simetria entre saberes, a contribuição de cada expertise se atendo em iluminar o outro campo. O livro aborda em condições de igualdade as contribuições xamânicas de Davi, bem como a história de luta pela demarcação, travada já no campo institucional das relações com o Estado.

Foi através dessa mesma CCPY, transformada em "Comissão Pró Yanomami” após a homologação da Terra Yanomami, em 23 de maio de 1992 que Davi efetivou seu projeto de escola para os Yanomami da região sob sua influência, uma demanda a qual convocou a ajuda de seus parceiros não Yanomami, aos quais eu vim a fazer parte, como assessor educacional.

Recentemente Manoela Carneiro da Cunha (2012) propõe que num trabalho colaborativo, não devemos buscar paralelos entre as duas visões de mundo, tentando apoiar o que cada um faz melhor. Sua posição se faz sensata em evitar colonialismos da ciência. Recentemente ela declarou que esse tipo de pensamento não deveria fazer parte da escola ${ }^{7}$. Isso é congruente com o que ouvimos dos Yanomami, que separavam muito bem conhecimentos tradicionais dos escolares, a educação Yanomami da educação escolar yanomami, elaboração presente no projeto político pedagógico das Escolas Yanomami, em reflexões promovidas no âmbito do Programa Yarapiari $^{8}$ (CASTRO; PEREIRA 2013). A separação consciente entre educação escolar Yanomami e educação Yanomami faz sentido

7 UFMG Colóquio Davi Kopenawa notícias da UFMG 21 de novembro de 2013. http://www.ufmg.br/online/arquivos/031025.shtml?fb_action_ids=10201798171329883\&fb_action_types=og.rec ommends\&fb_source=other_multiline\&action_object_map=\%5B598835173515803\%5D\&action_type_map=\% 5B"og.recommends"\%5D\&action_ref_map=\%5B\%5D

8 Yarapiari foi um programa de Formação intercultural de professores Yanomami, onde se gestaram as discussões e debates sobre a Escola Yanomami e culminando com a construção de um Projeto Político Pedagógico para as escolas Yanomami. Seu nome advém da entidade mítica de um pássaro, o sabiá (Turdus sp.) tido como muito inteligente por imitar diversos cantos. O Yarapiari teria ensinado os Yanomami a cantar. 
com os resultados encontrados por Kelly (2016), de absorver uma nova educação mantendo a sua, de concatena-la como dois elementos conscientemente distintos e separados, pois possuem seus espaços próprios de transmissão e efetividade.

O que ficou claro para nós, assessores das escolas Yanomami, era o desejo de aprenderem sobre a gente, de responder aquela questão da antropologia reversa: "quem são vocês?" Os Yanomami conviveram com uma variada gama de gentes não Yanomami (napëpë) e conseguiam categorizar alguns e perceber algumas de suas características, de forma semelhante com que o etnógrafo faz em seus estudos. Mas como já afirmei acima, o Estado Nacional é um conceito-chave para entender a sociedade de classes e a organização social napëpë. Daí a importância da descrição dos Yanomami acima: uma forma de organização sem Estado, sem poder central. Acrescente-se a intuição de Pierre Clastres (2003) a propor a interpretação de uma sociedade contra o Estado, no sentido de que há uma ação deliberada de seus membros para impedir uma verticalização do poder, exposto nas intermináveis vendetas que se estabelecem.

Para compreender uma sociedade de Estado, tivemos, enquanto assessores, um papel de facilitar essa investigação por parte dos Yanomami. Nessa experiência, acumulei materiais que revelam um pouco esse esforço. Assim, o objetivo aqui é relatar a experiência de uma 'antropologia reversa' dos Yanomami no tateio científico de descobrir nossa organização social de Estado. Ao mesmo tempo, expor em avaliação esse nosso papel de facilitador no processo de conhecimento, sabendo que essa busca essa investigação tem uma importância muito clara de guiar as ações de como lidar com esse outro (os napëpë). Há um contraponto necessário na questão de tratar os Yanomami como uma sociedade, uma nação sem Estado, ou contra o Estado: é a existência de setores de nossa sociedade que não acreditam ser isso verdade, consideram que os Yanomami, assim como as 'ONGs internacionais', seus apoiadores, querem criar um 'Estado Yanomami'. Embora possa parecer patético considerar livros equivocados como "A farsa Yanomami" como contraponto no debate acadêmico, dada sua superficialidade, o Clube Militar tem promovido debates no Rio de Janeiro com pensamento semelhante. Assim, terei nesse escrito uma pergunta de fundo: Há a possibilidade de um "Estado Yanomami"?

Como método, examinarei algumas categorias e representações dos Yanomami sobre os "seus outros", os não Yanomami e as relações interculturais vivenciadas de cada um desses 
variados atores (segundo meu testemunho entre outros), tendo como ferramenta conceitual a abordagem de alguns dos autores lidos. E tentando esclarecer nosso papel nessa discussão partindo do relato mesmo desse diálogo, as dúvidas e conceitos e hipóteses preliminares que iam se formando com a vivência das relações interculturais ${ }^{9}$.

Uma categorização dos napëpë foi percebida pelos Yanomami, que nos dividiram conforme principalmente a função profissional exercida, os "saúde theri" os "educação theripë" "Hunai Theri", uma divisão obviamente distinta das comunidades yanomami (theri $=$ 'povo', 'gente', podendo significar a divisão em comunidades, região ou mesmo povo Yanomami ), cuja percepção coaduna com a famosa expressão atribuida a Davi de 'povo das caixinhas', não só porque fisicamente vivemos em 'caixinhas' (nossas casas quadradas amontoadas umas sobre as outras) mas porque a própria vida se estabelece dividida em suas especializações. Mesmo pertencente à categoria napëpë, os Yanomami evidentemente nos distinguiam de outros que povoavam a cidade de Boa Vista, com os quais tiveram e tem uma relação muito mais conflitantes. Assim, para cumprir os objetivos desse trabalho, temos de descrever, relatar quem são esses que compõem a sociedade regional, elegendo principalmente a cidade de Boa Vista e os episódios de intolerância vivenciados pelos Yanomami.

Nossa convivência com os Yanomami, diferente já no nosso esforço de aprender a língua, entender o modo de pensar Yanomami, faz de nós aquilo que tenho tentado conceituar como um 'interlocutor saudável'. Conceito plasmado, ainda mal-definido, exposto aqui como postulado, a busca de substituir essa conceituação por outro melhor. Alguns aspectos guiam essa diferenciação: o esforço em entender o outro, não como mera tolerância, depende de termos um pensamento crítico sobre a nossa própria sociedade: parece condição necessária para a formação de um antropólogo ou de um trabalhador intercultural fazer essa crítica, buscando romper também com nosso próprio etnocentrismo, de ultrapassar nossas convenções sociais (WAGNER,1981: 29).

Claro que se auto-proclamar 'legítimos aliados dos Yanomami' seria aqui uma deselegância sem o menor rigor; por essa não ser uma questão central, aponto aqui apenas

9 Utilizo intercultural, interculturalidade como o tipo de relação entre culturas, dos Yanomami com outros povos e especialmente com as sociedades de Estado. Ciente das várias interpretações e nuances dadas ao termo, eu ainda assim o preferi. 
uma intuição a respeito de nosso esforço, longe de plenamente realizado, e carregado de equívocos 'em cada esquina', a intuição de que existe essa possibilidade de uma interlocução saudável com o outro, e essa interlocução pode ser diferencial na luta pelo reconhecimento que o outro trava, para a nossa sociedade. Pode mesmo ser o diferencial de sua sobrevivência enquanto parte da diversidade humana. Ou, se quisermos uma interpretação sobre o nosso papel mediador, do ponto de vista das estratégias políticas ameríndias:

“Os antropólogos e suas competências de mediação interétnica - além de seu papel habitual de fonte de bens de troca e de informações - aparecem para os índios, nesse contexto, como canais privilegiados de uma estratégia política de controle das representações de si através do espelho cultural da fronteira (Tilkin-Gallois 1991: 22). Essa "mediação etnográfica" da etnicidade opera, geralmente, em dois registros: como modo de restituição da especificidade cultural do discurso político indígena e como teste da comunicabilidade interétnica dos temas que veicula. Seu dialogismo político certamente contribui para catalisar a reflexividade cultural que subjaz à auto-afirmação étnica propagada pelos líderes indígenas."

(ALBERT, Bruce 1995 [2002] O ouro canibal e a queda do céu p.8)

O antropólogo aceita ser objeto da estratégia política Yanomami, inclusive se entregando à 'reeducação' que permitirá aprender o mundo do outro, no que Bruce Albert denominou posteriormente de um 'pacto etnográfico'.

\section{Uma Etnografia da sociedade de Estado, pelos Yanomami (La chute du ciel).}

O ouro canibal e a queda do céu (ALBERT 2002) já é, de alguma forma, uma leitura conceitual da nossa sociedade: ao analisar a fala de Davi Kopenawa, Bruce Albert atenta para o processo em que Davi passa de uma 'resistência especulativa', para uma 'adaptação resistente' em seu discurso, onde o primeiro momento é o da crítica, feita no seio das abordagens consistentes com o modo de pensar Yanomami, onde os napëpë aparecem como ininteligíveis, quase sub-humanos; e no segundo momento, reconhecendo a assimetria das relações políticas com o Estado nacional e a imagem que os brancos fazem de seu povo, assume uma adaptação resistente em seu discurso, onde ele já se explica como yanomami, índio que vive na floresta (urihi theri a) e expõe de forma contundente mas inteligível para os não Yanomami a leitura do momento em que viviam, com a incorporação das preocupações ambientalistas, parceiros circunstanciais da luta territorial Yanomami. E nisso, Davi capta bem uma das categorias de não Yanomami que vem a conhecer: os garimpeiros. Ele o interpreta pela estranha mística e fascínio que estes têm por um metal, uma matéria que compõe parte do 'esqueleto da terra', subproduto da hutukarari, "o céu que caiu" (voltaremos a examinar 
melhor essa explicação metafísica Yanomami). E religa mais a frente o que caracteriza os napëpë, como um povo de abundância em utensílios materiais, levando a uma formulação que tem paralelo na idéia de Marx sobre o 'fetichismo das mercadorias', sem obviamente ter lido esse autor (ALBERT 1995 [2002] p.16).

Exceto Davi Kopenawa, poucos tinham acesso a outros lugares do mundo além da realidade regional, cidades de Boa Vista e no máximo Manaus, como referências para formular uma visão mais abrangente sobre o(s) outro(s). A luta pela demarcação levou Davi ao privilégio de conhecer diversos lugares do mundo, na condição de expositor da luta de um povo da floresta. Bem assessorado a entender o contexto em que se realizava tal luta, tem sido dentre os Yanomami quem melhor conseguiu traduzir esse fenômeno que passa a se fazer presente com o contato. Davi sempre foi ouvido atentamente em seus hereamou (discursos, falas) na sua tradução sobre o mundo dos não yanomami. Por um outro lado, se Davi é tratado como uma 'autoridade' pelo seu conhecimento (e poder) sobre os brancos, quando está de visita a outras regiões às quais não mantém alianças comunitárias diretas, é tratado como 'alteridade': deve submeter-se ao sistema de trocas de utensílios (matehipë) ao qual os Yanomami mantém a relação de laços: numa frase de origem francesa, Bruce me explicou em comunicação pessoal, que "o bem substitui o laço", estando isso no fundo da ética Yanomami, tão logo um objeto é recebido em troca, ele é orgulhosamente posto a circular, experimentado por muitos outros sem um apego maior, pois o tornaria um sovina (xiimi), uma das mais desqualificadoras ofensas para um Yanomami. Esse quadro de diferenças nos dá uma noção de como as etiquetas se invertem: pedir, para um Yanomami, é um convite a uma amizade, a uma relação social amistosa, nohimouwei, no entanto no meio urbano tal atitude seria vista como um pedinte, algo deplorável aos olhos de nossa sociedade. Jose Kelly Luciani (2011) conta uma anedota semelhante nas relações entre profissionais da saúde e Yanomami da Venezuela, traduzindo os sentimentos mútuos entre médicos que consideravam os Yanomami uns 'gatunos', e os Yanomami que consideravam os profissionais de medicina uns sovinas. Até nesses detalhes, Davi tinha, internamente, uma enorme tarefa pela frente, de disseminar entre os Yanomami conhecimentos que lhes permitiriam a sobrevivência, no novo contexto, diante da sociedade de Estado.

Em “O ouro canibal e a Queda do Céu”(ALBERT 2002) já se faz presente na luta de Davi e dos Yanomami um caráter cosmológico, onde a luta não se trata de medição de forças, mas de mediação e convencimento e onde a questão principal está em projetos do que fazer 
com o mundo, num contexto em que os agenciamentos das sociedades de Estado, enquanto sociedades industriais, capitalistas, estavam levando ao aquecimento global, às mudanças climáticas, ou, na cosmovisão de Davi e dos Yanomami, à queda do céu.

\section{Esforços do PEI na construção de um conhecimento sobre o Estado}

Após a demarcação, o projeto de Davi Kopenawa foi estabelecer escolas Yanomami a partir de uma experiência piloto em sua comunidade, o Demini e posteriormente, por um intercâmbio totalmente protagonizado pelas comunidades participantes, quando alguns jovens do Toototopi foram estudar e se alfabetizar no Demini. Esse projeto se concretizou no Programa de Educação Intercultural (PEI). Eu tomei contato com o programa no seu primeiro curso de formação (2001), quando ainda trabalhava na saúde com dados epidemiológicos lançados num sistema de informações geográficas, minha competência. Fui convidado por amigos (que se tornaram colegas) a participar do curso de formação e acabei por trocar o trabalho em saúde e fui contratado para continuar a experiência. Com a equipe, já vínhamos discutindo como abordar o Estado como categoria necessária para entender nossa sociedade.

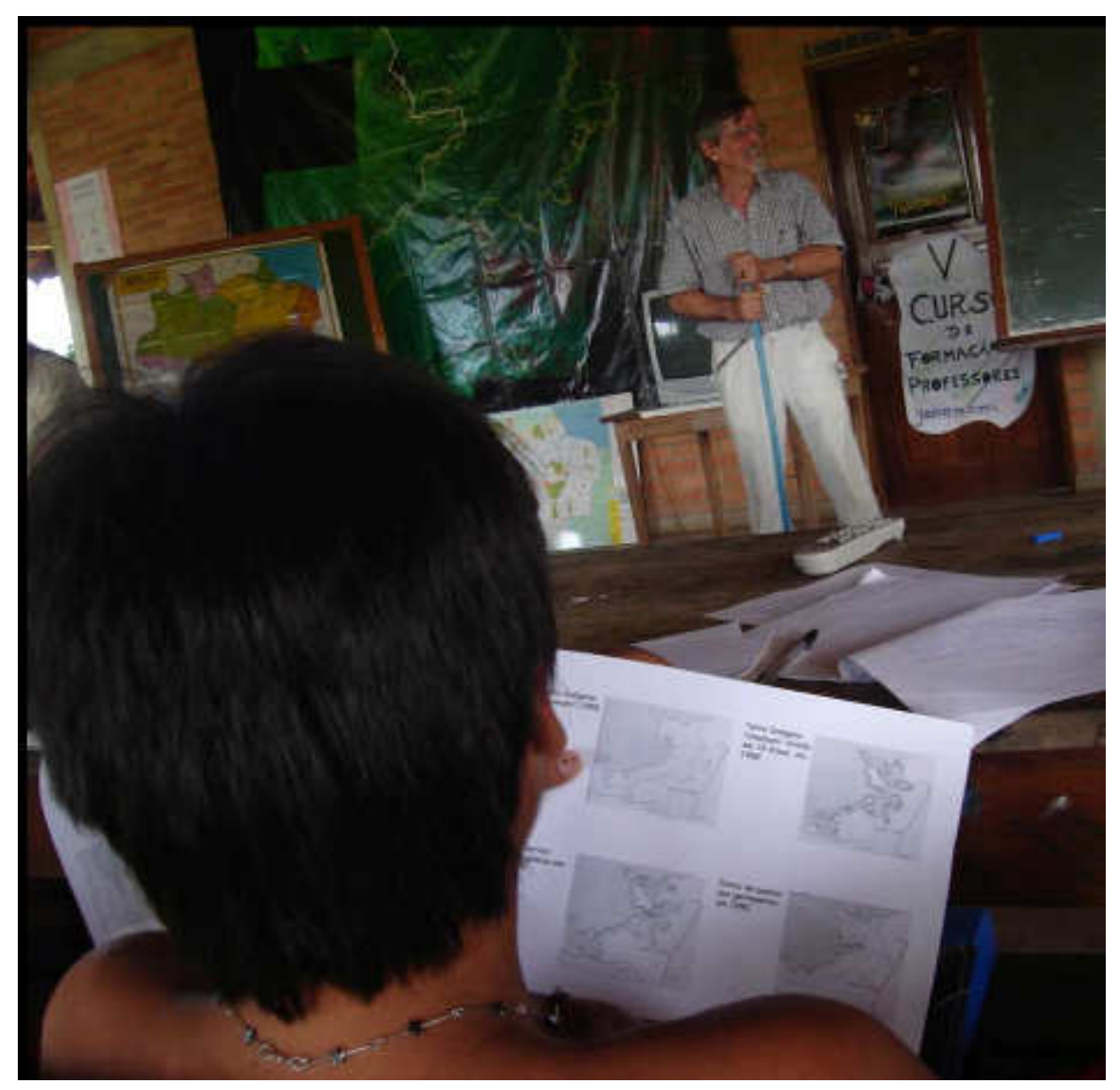

Figura 2: Yanomami observa mapa com propostas de demarcação da Terra Yanomami, enquanto Carlo Zacquini conta a História da demarcação. V curso de Formação em 2005 na Casa de cura, Hekura Yano, Boa Vista -RR 
Nosso trabalho com os professores Yanomami para decifrarem nossa organização social se deu em nove cursos de formação, mais uma série de atividades que incluíam informática e intercâmbios de língua portuguesa (CASTRO; PEREIRA, 2013); os Yanomami eram de maioria monolíngues, então. Nossas opções não eram impensadas, mas fruto de reflexões conjuntas, incluindo Davi. As ferramentas conceituais como o português e a matemática eram importantes, bem como os mapas. Descobrimos que as ferramentas tecnológicas, a computação poderia ser utilizada na própria valorização da língua, mediando os novos conhecimentos. A alfabetização e o letramento tiveram desde o início uma rede de jornais em Yanomami que comentavam problemas vivenciados nas relações com os não Yanomami napë, no atendimento à saúde, os projetos de mineração, a descoberta de garimpos, problemas com preconceitos, como o caso de uma pessoa em Boa Vista que publicou um anúncio "vendem-se filhotes de Yanomami", como se fossem cachorros e foi condenado pelo seu preconceito ${ }^{10}$. Os intercâmbios para áreas distantes, quando alguns professores eram convidados a conhecer outra situação indígena, sempre foram oportunidades para aumentarem o rol de referências externas, tanto de paisagens como de situações de contato, de pressões econômicas etc.

A cidade de Boa Vista era para a maioria dos Yanomami com quem trabalhei a referência comum de cidade. Uma cidade estrategicamente geopolítica por se tratar da capital de território federal promovido a Estado (BRASIL, 1988), na fronteira amazônica, de forte influência militar, em parte razão do nacionalismo xenofóbico disseminado na população. A população, de maioria migrante, cresceu consideravelmente após a década de 1980, quando se iniciou a busca pelos garimpos na região, devido à presença de ouro ter sido confirmada por informes do Radam (BRASIL, 1975) sobretudo nas terras indígenas. O fechamento do garimpo, com a demarcação e toda a campanha e projeto político da elite roraimense, não curou tais feridas.

Os Yanomami sentiram na pele esse preconceito e essa malícia, quando faziam suas compras de utensílios para levar para a floresta, sendo ora enganados, ora ouvindo frases como "volta pra tua terra, aqui não é lugar de índio", mesmo estando com dinheiro, diferente dos que iam por conta ou por remoção de saúde. Um grupo de garimpeiros que se entregou no Catrimani, local de nosso primeiro curso, uma senhora afirmou: "essa terra é do Brasil, não é

10 cf. jornal do Papiu, escrito em Yanomama, sobre o anúncio, mostrando indignação pelo fato: http://www.proyanomami.org.br/v0904/jornais_yanomami/paapiu/Jornal_Maloca_Papiu_05.pdf acessado em 13 de agosto de 2017 
dos estrangeiros", incluindo os índios entre 'os estrangeiros', e se arvorando a representante nata do Brasil. Tal modo de pensar era exposto como material pedagógico para compreender o pensamento existente em tais discursos.

Os preconceitos revelados nas atitudes discriminatórias perpassavam o poder público e as agências bancárias, de correios entre outras: era incrivelmente excludente que repartições públicas proibissem a entrada de calções ou de chinelos em pleno calor amazônico. Os Yanomami foram algumas vezes barrados por essa razão, independente dos direitos assegurados pela lei. Ouviram certa vez na secretaria de educação "que eram primitivos", numa tentativa de justificar a ausência de atendimento escolar público.

Tais episódios faziam da cidade um laboratório para vivenciarem algumas categorias de napëpë mais comuns, que eram então classificadas pelas suas origens profissionais, mas que guardavam diferenças de classes, essas logo percebidas, mas sem uma lógica que as estruturassem num pensamento coerente. Evidências de hierarquias, comuns no sistema médico, mas pouco permeáveis em termos de uma reflexão mais contundente. Era muito mais o 'medo ao pequeno número', disseminado por toda a sociedade, o fenômeno mais contundente. Por essa razão, ao momento em que propusemos uma imersão em língua portuguesa, adotamos um contato com os outros povos indígenas de Roraima, os Macuxi, Ingarikó, Taurepang (carib) e Wapichana (aruak) que habitam os lavrados, campos naturais do leste Roraimense, para fazerem um intercâmbio incluindo a língua portuguesa e a causa indígena, à qual poder-se-ia vincular a luta Yanomami, em sua especificidade.

Nas primeiras experiências, a percepção dos Yanomami levou a interpretações desfeitas pela própria continuidade: que os macuxi 'já eram brancos', que os campos teriam sido desmatados (era difícil imaginar, para um povo cujo universo era florestal a existência de nãofloresta natural, os lavrados). Mas uma questão central os levou a uma aproximação foi a luta dos povos indígenas em torno da homologação da Terra Indígena Raposa/Serra do Sol.

Um dos episódios mais polêmicos e emblemáticos da luta indígena nacional, uma vez que os povos indígenas de Roraima foram utilizados como argumento em corte internacional, ainda no séc XIX para garantir o território brasileiro, com quem mantinham relações comerciais amistosas, a presença indígena era interpretada como "as Muralhas dos Sertões" (FARAGE, 1991). Tal fato por si atestava a territorialidade indígena ali. Mas o poder local, o 
governo estadual, depois de todo um processo repressivo, com a tomada de consciência dos índios e a auto-demarcação efetivada em 1997, incentivou a produção de arroz ali, em nova invasão. A Figura 3 expõe o contexto dessas terras indígenas de Roraima em relação à Terra Yanomami, demonstrando a importância da TI Raposa Serra do Sol como a maior área contínua do lavrado roraimense.

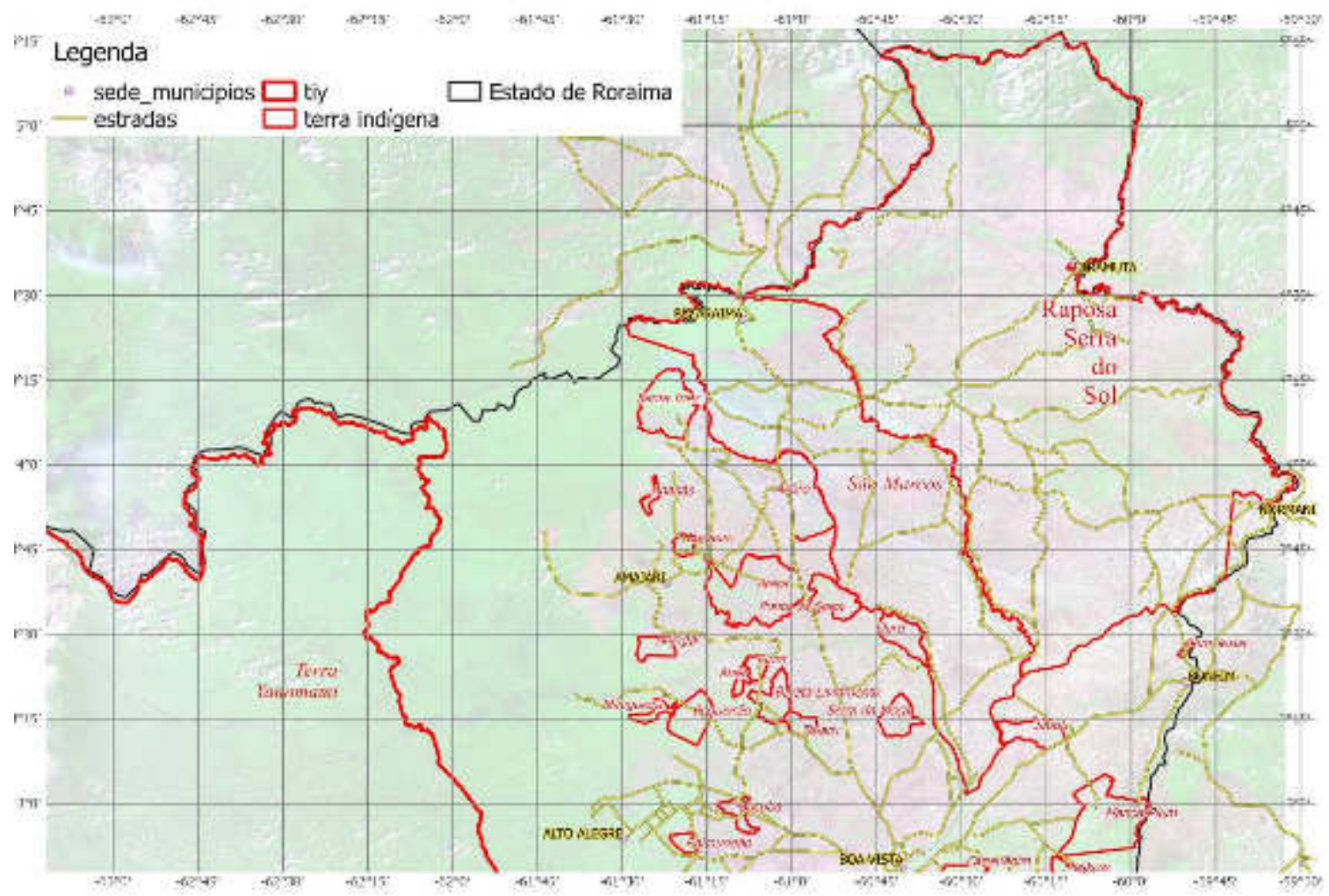

Figura 3 Mapa das Terras Indígenas do Lavrado de Roraima, campos naturais (representado por tons rosados); destaque para a Raposa/Serra do Sol (1700mil hectares), a São Marcos e a Terra Yanomami, únicas que não foram demarcadas em ilhas

Vou relatar passagens selecionadas em que o nosso esforço gerou textos interessantes, “filtrados" pela visão Yanomami, gerando uma síntese positiva nas representações sobre o mundo dos brancos. Houve muito mais, mas examinar algumas parece-me suficiente para proporcionar uma discussão dentro dos objetivos do texto. Um sobre "outros indígenas" (ai Yanomami). Um segundo sobre as leis. Tentaremos apresentar brevemente nossas ações, e um retorno na forma de texto escrito (na língua e traduzido).

\section{Maturuca hamë Macuxi pë hereamuwi thë ã oni}

Macuxipë hereamo pëha kami yanomae yamaki pree pairioma; professores yama ki pairioma Intercâmbio yama a thai tëhë yama ki pairioma. Awei Macuxi pë hereamou tëhë hapënaha thë thamahe. Macuxi pë kakii kama pë urihi pë ha pë lutamou homologação thë thaihe ihi makii presidente ani e thë urihi oni thapraimi xoa yaro kuë yaro napë e pë rukët xoa 
Kuë makii luta a homologação thë thai xiwarihe ${ }^{11}$

Nesse texto, o professor demonstra a preocupação solidária com os habitantes da Raposa Serra do Sol, adquirida no processo de intercâmbio. Isso marca um novo recorte de identidades para os Yanomami, a identificação como índios, e aos Makuxi passaram a considerá-los “ai yanomami” 'outros yanomami'. Os intercâmbios foram importantes para tomarem conhecimento também afetivo com os outros povos indígenas de Roraima. Esses novos recortes identitários, construídos pela similaridade de lutas, rompem com representações reificadas sobre os sujeitos históricos, que constroem suas próprias, lutando contra os preconceitos a eles impingidos. A supressão de direitos se dá, ora por serem primitivos - os Yanomami - ora 'porque não são mais índios' - os Makuxi (NILSSON 2011).

Raposa Serra do Sol ha homologação a kuaimixoa. Kuë yaro garimpeiros pë kua fazendeiros pë pree kua. Thëpë kua yaro arroz pë tiaremahe. Fazenda aha napëpënt arroz pë tiaihe. thi makii arroz pëha tiat tëhë ai pë nikeraihe veneno agrotoxico thëpë ãha kua fazendeiro pëni makuxi pë urihipëha arroz pë waroho mahi tiaihe. Hutukana pë pata mahi thał yarohe thë yai totihiimi. $^{12}$

Sidinei Nanari Yanomami

O mesmo professor expõe questões aprendidas com os Makuxi e aprimorou no diálogo com os assessores. Escrito para um jornal de circulação em área, usado como material de disseminação das experiências externas dos professores, para não se restringir os saberes a poucas pessoas. Aí já aparecem questões sobre os projetos conflitantes, como a diferença na forma de plantar e a indignação de não se fazer roça 'como os Yanomami'. Isso reforça a leitura de Appadurai (2009) sobre o papel dissidente das minorias em se opor ao projeto hegemônico. Observa-se também o reconhecimento do poder central e a expectativa dos Yanomami (assim como outros povos indígenas) a seu respeito: o cumprimento dos seus deveres de protege-los enquanto minorias, garantindo seus direitos de usufruto exclusivo sobre o território.

11 Sobre a reunião dos Makuxi, no Maturuca (comunidade no norte da Raposa Serra do Sol): nós professores Yanomami também participamos da reunião dos Makuxi. Participamos como professores, quando nós fizemos o intercâmbio. Na Reunião os makuxi falaram que eles ainda lutam pela terra, eles querem homologação, mas o presidente ainda não assinou o texto da terra deles, por isso os napëpë ainda entram. E portanto, eles lutam persistentemente pela homologação. (2003)

12 Na Raposa Serra do Sol ainda não há homologação. Por isso há garimpeiros e fazendeiros. Em razão disso eles, os brancos, plantam arroz na fazenda, mas quando plantam, eles misturam veneno agrotoxico é o nome dele. Os fazendeiros na floresta dos Makuxi eles plantam muito arroz. Eles fazem uma plantação tão imensa que não é positivo 
O tema dos direitos indígenas foi também trabalhado em várias oportunidades além das questões territoriais, pensando os recentes reconhecimentos estabelecidos pela Constituição Federal de 1988 (BRASIL, 1988), que, em seu artigo 232 garante a autonomia processual ao definir que um povo indígena pode ingressar na justiça sem depender da Funai. Isso na prática acaba com a tutela. A tutela foi tema de um texto do Professor Alfredo Himotona do Papiu:

Tutela thãkaki uti pithãha kua, kura?

Awei napëpënë kami yanomama yama ki pihi mohoti himai wihi ihi tutela thaha kua hapainaha yanomama yamaki ha napëpë pihikuu yanomama thëpë pihi mohoti kama yami thëpë urihipë noamamu tamoimi, yami thëpë pirio tamoimi, kama yami thëpë pihi kutamoimi, yami thëpë praha huu tamoimi, kami funai yama kiha yami yanomama thëpëa hai tamoimi, yanomama yami thëpënë documento pë thaprai taimihe, napë thãha yami yanomama thëpëa hai tamoimi, yami thëpënë Dinheiro a kotamai taimihe, incapacidade thëpë kutayoni inaha kami yanomama yama ki ha funai pihikuu kua yaro komi napëpë pihiku yutuha napëpë pihi ku mamaki hei tëhë pë pihi kuhe yati xoa,inaha kua yaro hapainaha funai pihi kuu yanomama thëpë kaki thëpë oxe yaro kami yanë yanomama yathëpë hiima pou xoa kama yami thëpë noamioimi yaro kami funai yanë yanomama thëpë noamai yaro ipa hiima yanomama thëpë inaha funai a pihi ku,kua yaro komi napëpë pihi kuu xoa hei tutela thãka kiha, kua yaro 1973 hei tutela thã, thapraremamakihi hei tëhë thã xoahe yatia xoa kami yanomama yama kiha napëpë pihi kuhe yatia xoa inaha kua yaro yanomama thëpë urihipë hami ai napëpë urihi a wariai he tëhë kami funai yama kinë herea yama aha thaprarini yanomama yama thëpë urihipë xiro noami prai inaha funai apihi kuu ai napë pata motima pëxo komi thëpë pihi ku xoa hei tutela thãha.

Awei kua hikia maprarioma

Alfredo Himotono yanomama. ${ }^{13}$

A indignação de Alfredo Yanomami, ao descobrir que era visto como um 'cachorrinho que precisa ser guiado', que nem a própria floresta teria condições de defender e que essa imagem perpassaria toda a sociedade, é uma das leituras sobre quando somos objeto de lei. $\mathrm{O}$ papel do Estado em legislar sem a participação do povo, demonstra que o poder central tem um projeto para os povos indígenas, numa abordagem autoritária.

Essa abordagem tem sido questionada com a auto-defesa dos Yanomami perante aos

13 O fato de os não indígenas considerarem a nós Yanomami como incapazes, ignorantes, se chama tutela, os não yanomami pensam em relação a nós que não somos capazes de proteger nossa terra sozinhos nem sabemos viver sozinhos, e não pensamos sozinhos, não podemos ir longe sozinhos. A Funai não nos deixa falar sozinhos por nós mesmos, não sabemos contar o dinheiro, por sermos incapazes, é assim que a Funai pensa de nós Yanomama. Por isso todos os não indígenas pensam assim. Antes os não indígenas pensavam assim mas hoje eles ainda pensam. Por isso a Funai nos considera como se fôssemos criança. Eles nos conduzem como nõs conduzimos um animal de estimação, não nos deixam soltos, e consideram que estão nos protegendo, como fosse um animal de estimação. E por isso os não indígenas continuam pensando assim sobre nós. Por isso em 1973 apesar de eles terem feito essa lei, e ela persiste até hoje. Por isso na nossa terra, quando outros não indígenas a destroem. Depois de fazer reunião conosco a Funai pensa igual os poderosos também ainda falam de tutela. 
projetos de Estado sobre eles e seus territórios. Um dos mais importantes, o projeto de mineração em terras indígenas, demonstra como funciona o sistema de poder central: estamos longe de quem decide sobre nossa própria floresta, decidir de forma diferente da vontade geral. Daqueles para quem o diálogo com o poder é quase inacessível. E um dos mecanismos para a inacessibilidade, além da distância geográfica (e do segurança na porta) está a desqualificação do discurso do outro, ao qual converge a doutrina da tutela.

\section{A criação da Hutukara Associação Yanomami}

A criação da Hutukara Associação Yanomami em 2004 foi mais um passo no projeto político de Davi Kopenawa, de defesa dos direitos dos Yanomami. Com uma equipe mais preparada para entender os discursos e representações sobre si (feitas pelo outro, sendo esse outro uma sociedade com Estado), e os recortes institucionais a lhes garantir direitos (ou lhes retirar), o diálogo e os conflitos com a sociedade de Estado tem agora um interlocutor atuante. O desafio maior é o de pactuar com os Yanomami de área, esclarecendo suas ações, difíceis de entender por quem interpreta o mundo com outros parâmetros, ao mesmo tempo em que enfrenta esse diálogo externo, mediado pela escrita.

Para dimensionar a diferença nos modos de entender, vou relatar o episódio mitológico fundador do nome da Associação Hutukara: "Hutukarari", é a entidade mítica do céu que caiu, ou seja, a origem de nossa terra atual: Nossa terra é formada por esse céu, no tempo em que os Yanomami construíram o primeiro céu, no tempo de Omama (o demiurgo Yanomami), esse céu não foi firmemente apoiado pelos mastros que o sustentavam. O céu cai, matando quase todos os Yanomami soterrados, e hoje suas costas formam a paisagem de montanhas e planícies conhecidas atualmente. Omama não morre: fica preso por entre rochas em alguma cavidade junto com sua família, outras árvores quebraram, mas o pé de cacaueiro porounahi vergou e sustentou as rochas onde Omama está. O papagaio consegue remover algumas rochas e ele alcança novamente à superfície; na superfície, Omama reconstrói o céu com esteios firmes para não cair novamente"(Davi, em comunicação pessoal em 2006). A associação tem seu nome inspirado em um episódio vivido por Omama, fundador da humanidade Yanomami, ao mesmo tempo possui a atribuição de competentemente "navegar no mundo dos brancos", uma ferramenta constituída e regrada essencialmente pelo papel.

A defesa da Terra sempre foi uma prioridade para a associação, já o era antes, pela luta pela terra contínua contra a proposta militar-estatal de fragmentar o território. O local de desintrusão dos mais importantes foi o Ajarani. Único local onde a interesse de pouquíssimos 
fazendeiros persistia não Yanomami, desde a primeira violência geográfica-estatal, a construção da BR-210 (Perimetral Norte). A Figura 4 abaixo demonstra a evolução da paisagem nessa região com intensa atividade dos pecuaristas.
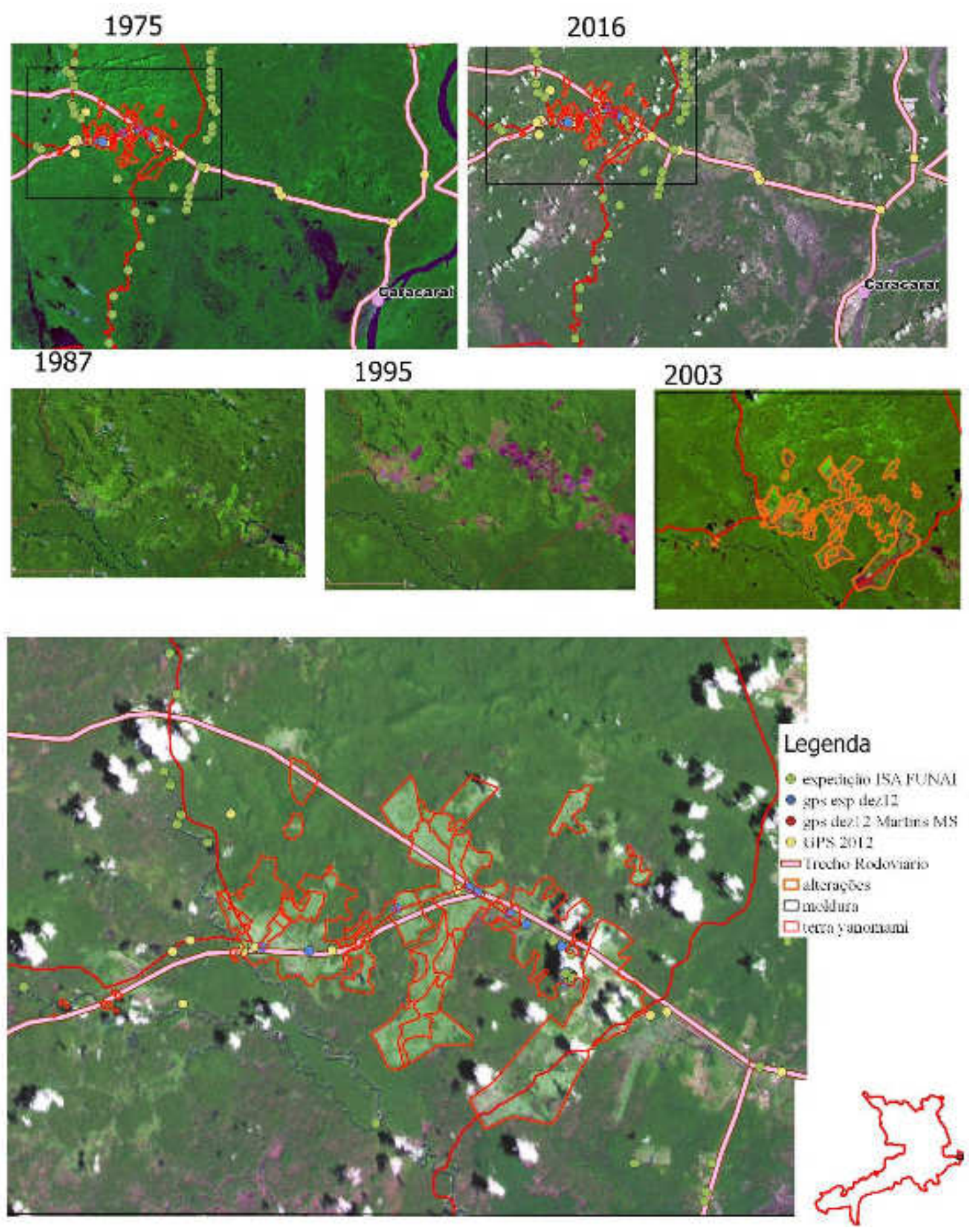

Figura 4: Terra Indígena Yanomami Ajarani: no eixo da BR 210 desmates provocados pelos pecuaristas que concentraram as terras provenientes de invasões da área demarcada. Contexto com Caracaraí e assentamentos, 1975(construção da BR210) e hoje (2016) Evolução histórica das alterações; anos de 1987, 1995, 2003 e 2016.

Transcrevo um excerto de autoria de Nadia Farage (1999), respondendo a quesitos no processo de desintrusão e que dá conta de apresentar o personagem protagonista da narrativa, e o desfecho da ação, com a argumentação que lhe embasava. 
Não foi localizada documentação no Cartório de Registro de Imóveis do município de Caracaraí quanto a estas terras. Consta no INCRA-RR solicitação para regularização fundiária, por parte de Ermilo Paludo, datada, inicialmente, de junho de 1983 (INCRA, Proc.1125/83). Verifica-se, na referida documentação, que tais terras, com área de 700 há, foram obtidas por compra feita a Walter Miranda Jr., em novembro de 1980 (INCRA, Proc.1125/83, fls.05). Feita a vistoria, o INCRA veio a propor a regularização de 143,0 ha em nome de Ermilo Paludo, ao invés dos 429,2011 ha requeridos (INCRA, Proc.1125/83, fls.10ss), para os quais emitiu contrato de promessa de compra e venda em 1983 (INCRA, Proc.1125/83, fls.30).

Em junho de 1990, Ermilo Paludo veio a requerer reconsideração da área para 450 hectares (INCRA, Proc.1125/83, fls.37), solicitação renovada em outubro daquele ano (INCRA, Proc.1125/83, apenso, fls.01). Ali, declara ocupar a referida área desde 1981 (Proc.1125/83, apenso, fls.02). O INCRA não deu prosseguimento à tramitação do processo, com a seguinte manifestação:

"Após constatarmos os trabalhos fornecidos pela FUNAI, deixamos de informar conforme o solicitado tendo em vistas que a área que abrange a posse junto a FUNAI encontra-se interditada pela Justiça, ficamos assim impossibilitados de informar com exatidão até que haja uma definição da Justiça - DF.

Em 18.02.91

José Ribamar de Souza

Ch.Sub. GT-2"

(INCRA, Proc.1125/83, fls.13)

(Farage, 1999)

Em 2007, Resta ele, o último a não sair da terra já demarcada e homologada, processo longo ao qual Davi se dedicou a vida inteira; para manter-se na terra, o famigerado fazendeiro vinha usando de subterfúgios para cooptar a população local, os Yawaripë, validos de sua condição trágica de vítimas da estrada Perimetral Norte, oferecendo-lhe uma cabeça de gado para que o aceitassem ali.

Vejamos agora um discurso de Davi Kopenawa, já após a criação da associação. Esse discurso foi proclamado em reunião pública com membros de uma comunidade na fronteira da Terra Yanomami, no único trecho em que havia invasões por fazendeiros (NILSSON, 2011), particularmente um persistente, Paludo, que se recusava a sair, diante da retirada iminente, já decidida na justiça. Davi tenta convencer aquele pessoal, cuja liderança é um velho conhecido (seus irmãos o acompanharam na saga do Watoriki, sua comunidade, nascida no antigo Km 210 da Rodovia Perimetral Norte, agregando também aos antigos Uxiu theri, Kuisi Theri) de proteger a terra e se aliar com os outros Yanomami, depois de sua liderança ter se declarado desassistido:

$$
(\text { veja tradução })^{14}
$$

14 : Essa nossa associação, não foram eles que me mandaram fazer; eu sozinho que a criei, antes eu lutei, primeiro eu lutei com os garimpeiros outros tiveram medo (cita nomes) eles não alvejaram (os inimigos) vocês sabem já, portanto, ainda há luta por fazer, a luta não acabou. Se ela não fechar a terra, na nossa floresta o 
Kami yamakint hei associação thë kakii, hei pëni (aponta para os napë) ware nosiamounimihe; kami yãmi ya thë thaprarema hapa ya lutamoma garimpeiro ya thë lutamou pariomama (...) ai thëpë kiri yaro a niaprai maomahe ai a kiriprarioma wama thë that hikiohe

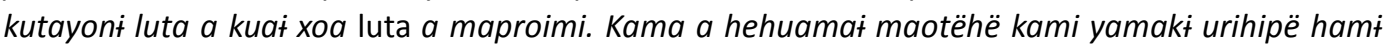
thëpë mapru. Inaha yama ki pihiku Hutukara ani wamaki nakarema encontro regional vigilância terrritório yanomami yamaki thai pihio, yamaki mamoxatio...

Federal governo federal ani urihi demarcação thaihikiprarema homologado registrado assinado governo presidente assinou, não tá garantido! por isso os brancos estão tentando... não tá garantido, esse registro da terra está na mão deles; kama ehami kama pata thëpëní registro $a$ thapraiwi a pou yarohe urihi napë ahetou xoahe. inaha napëni ahete makurahi hei yamaki

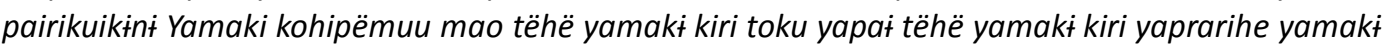

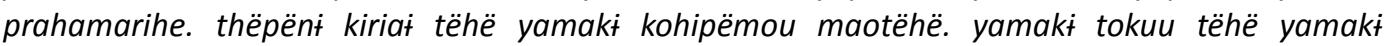
niaprarihe; thëpë kuu tëhë thëpë tirakii tëhë thi tëhë yamaki horepë ya "ma, yanomae thëpë

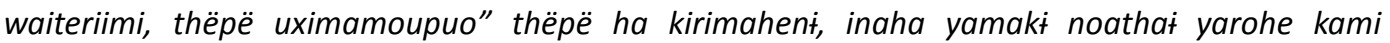
yamakini pata pëní, yamaki pata kuapënaha yamaki niyatyoma yamaki pata kirimayoma "uh, witipi thë ha patapëni napë yamaki kirimayou tha?" kama yayoa theri paxio. Yayoa napëpë Kama napë urihi Brasil inteiro thë kakii Brasil geral makii, urihi brasil urihi pata mahi makii witipii thëha yamaki urihipë hami thëpë ohotat? yamaki pihikuu. Kuwë yaro Hutukara Associação a pihikurayoma yaro, a pihi ha yawërint thit tëhë yamaki luta yama a tararema.

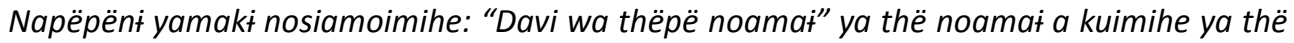
noamai tëhë thëpë pairimou yama nakał kura thëpë pairikii;

ibama pairiki; ministério público pairiki; Funai pairikii "wa thë urihi noamai" inaha ya kuu yaro thëpë huu Thëpë tokuimi makii yama a that tëhë kama pë toku huurayu tëhë thëpë hapa korayoma makii kami ya hapa xëprarihe tha?

kama hixio tëhë ya thëpë xëprai tha? kahikini xiro!

Demarcação pata pëni 1992 kuo tëhë reunião yama aha thaprarini patapëhami napë pata pëhamit, kaho wa tuteha kokini hei paludo wamaki hirimaiwi kama a that wawëto thëpë ohotai

povo se acaba. Por isso eu penso assim: a Hutukara está convidando vocês para um encontro regional de vigilância do território Yanomami, nós queremos realizar para ficar atentos(...)

O governo federal já fez a demarcação, está homologada, registrada, assinada, o governo já assinou mas não está garantido! Por isso os brancos estão tentando,... não está garantido, esse registro da terra está na mão deles, os governantes que o fizeram e detém o registro na mão, e os brancos estão próximos e da forma como estão próximos, a gente tomando a frente, se nós não formos fortes, se nós recuarmos com medo, se agente se afastar deles, se eles nos botarem medo se nós não formos fortes. Se nós fugirmos eles nos alvejam; se eles disserem, com a gente acovardada: "não esses yanomami não são valentes eles se pintam de preto à toa" depois de nos aterrorizarem, assim que eles nos ameaçarem, nós os velhos, agindo do modo como as lideranças que já flecharam, nós botamos medo neles "oh por que os velhos Yanomami estão botando medo em nós brancos?" por que eles são outros, diferentes, claro. Esses diferentes tem a terra deles que é o Brasil inteiro, uma floresta inteira o Brasil geral e apesar de o Brasil ser muito grande por que eles querem nos fazer sofrer em nossa floresta? Nós pensamos. Por isso, a Hutukara associação refletiu e se esclarecendo vimos o caminho da luta.

Os brancos não mandaram na gente: "Davi, vá proteger teu povo" isso não houve, essa ordem. Quando eu me pus a proteger o povo eles vieram do meu lado, eu convocando, eles vieram do meu lado, o Ibama se juntou, o Ministério Público se juntou, a Funai se juntou porque eu disse a eles protejam [a nossa floresta]! Se eles não fugiram quando eu fiz isso se eles fugiram e voltaram, eles me batem antes? Se eles estiverem possessos eu vou bater neles? Com a linguagem! Com a minha fala !

A demarcação, as lideranças em 1992 nós fizemos reunião lá onde é o governo deles e vocês eram jovens, esse Paludo (nome do fazendeiro) que lhes fez ouvir, ele já tinha claro, e sofrem a toa, ele tem clareza: se os velhos morrem também nós morreremos. Eu não sou criminoso, eu não sou alvejador de brancos eu só defendo a nossa terra, já que eu cresci nessa terra e me criei nessa terra, na nossa única terra yanomami para a gente viver para sempre. Dessa mesma forma se nós não tivermos nossa terra o que nós comeremos? Se eles limparem a terra se eles estragarem a terra, se essa floresta a que me refiro acabar, essa que está sendo destruída, o que o fazendeiro vai te dar? Um carro ou um avião? Se acabar a floresta onde a gente vive ali perto a gente mora, por isso vamos defender essa floresta. 
puo. kama a kãi wawëto: pata nomarayou pree yamaki nomaí. Kami criminoso ya kuaimi: kami nape niatima ya imi kami yanomae noamatima kami yamaki ya xiro paxio ipa urihiha ya patarayoma yaro,kutarenaha yamaki pirio kutarenaha demarcação terra yanomami unico yanomae yamakt piriotiwi thëpë urihi hipikema yarohe (...) yamaki nowaripouwi kurenaha tëhë urihi a maotëhë witi pi wama thë wapë? urihi a hoxiprariotëhë hei të kaki urihi thë haikiari tëhë urihi wariaiwihi wariarihetëhë fazendeiro pëni witi pei thë hipikii kami yamakiha? avião wa hipikii tha? carro a hipikii tha? yano a hipikii tha?

Urihi haikiari tëhë kami yamaki piria, ahete yamaki piria yaro kuwë yaro kami yamaki urihi yama a noamat

Davi Kopenawa em reunião em 2007 com autoridades na comunidade d o Ajarani;depois de ter ouvido as posições da comunidade

Se observarmos sua tradução, veremos várias figuras de linguagem sobre pintar-se de preto (para guerrear) e que depois Davi explica o sentido figurativo de 'bater' usando a fala. Dois aspectos políticos saltam aos olhos alí: o primeiro é que Davi deixa claro seu protagonismo, tanto na criação da associação como na proteção da terra e que os brancos o ajudam porque são chamados; e o segundo é que ele não tem nenhum poder sobre os outros Yanomami, a não ser a persuasão pela negociação, pelo convencimento.

Analisando o exposto de Davi à luz dos dois sistemas conviventes no desafio da associação: de um lado, aquele anárquico vivido entre Yanomami, e a ferramenta dos napëpë, no sentido de que já dialoga com o Estado e com expoentes da humanidade não Yanomami para produzir efeitos na sua luta. A fala de Davi reverte uma condição que é comum na relação com as sociedades de Estado: de ser ditada pelos não-Yanomami. É comum os Yanomami serem recrutados a trabalhar nas fazendas, na lida com o gado, da derrubada e na destoca. O grande estrago representado pelo Ajarani, com mais de cinco mil hectares de área contínua desmatada, foi realizado com mão de obra indígena, em grande parte. A mando dos fazendeiros, isso representa uma subordinação, ao qual só é dado ao Yanomami (assim como aos indígenas de outra região do Brasil) a possibilidade do trabalho. Possibilidade essa, tratada pelos não Yanomami como "um favor, uma ajuda". Nas palavras de Davi, aquilo que é o comum, o esperado, se reverte em uma condição diferente; conforme Davi afirma, não foram os napëpë que mandaram ele fazer associação. Foi ele quem realizou a fundação, com a ajuda dos napëpë. Aqui, Davi pontua uma diferença, de que sua idealização de uma associação para proteger a terra e a floresta tenha sido seguida pelos napëpë, não pela imposição, não por ordem, mas por convencimento, Davi conclama a participação de seus aliados utilizando-se do poder da palavra, que, como vimos acima, é o modo como também age em relação aos outros Yanomami. O Ajarani foi afinal desintrusado, saindo os últimos 
fazendeiros ali $\left(2014^{15}\right)$.

Os Yanomami mantém em suas relações uma negação do servir, do recurso de ser regido por leis escritas, normas mais poderosas que o processo político que leva ao consenso. Há uma frase um de meus colegas formulou diante das longas reuniões assembleias Yanomami: a de que em política Yanomami 'quem cala não consente'. Todos devem se pronunciar, para dizer no que concordam e no que discordam, agregando novos argumentos. Uma discordância final numa reunião pode levar a mais uma rodada de pronunciamentos. Implica em respeitar o tempo de um acordo realmente estabelecido. Disso prescinde o Estado com poder de polícia. O esforço e a energia em alcançar o consenso, a melhor solução através da negociação, tem correspondência com a energia despendida nas negociações xamânicas pelo equilíbrio do mundo (TAYLOR, 1996). A improvável formação de um Estado Yanomami, teria um caráter quase rousseauniano, se é possível mesmo detectar a 'vontade geral' (ROUSSEAU, 1762[2001]), passaria por essa dedicação que encontramos no hereamou yanomami. O posicionamento diante das instituições governamentais, de uma negociação perseverante onde se espera o cumprimento de seus deveres constitucionais para com os Yanomami (e outros indígenas por extensão) demonstra que, mais do que querer outro Estado, há uma aceitação do já existente (desde que este lhe sirva, freando os ímpetos do interesse econômico). Mas a questão que parece dificultar essa relação é o fundamento positivista das normas, onde os raciocínios são formulados a partir de uma lógica formal: uma coisa ou é, ou não é, ao ponto de Safatle (2012), baseado em Agamben (2005) considerar a possibilidade de as lutas por reconhecimento não proporem uma solução normativa, mas mesmo a sua ausência. A dificuldade para o pensamento da sociedade de Estado como constituída hoje é de admitir como legítimo qualquer discurso que fuja à formalidade da razão tal como a formulamos. Uma dificuldade de admitir a possibilidade de outras racionalidades, desqualificando-as e deslegitimando-as. Safatle critica aqui a representação incompleta do homem quando se desconsideram seus sonhos, suas pulsões, e o reduzem à razão.

\section{Conclusão}

Esse capítulo apresenta um pouco das experiências políticas dos Yanomami, desde o já

15 http://www.funai.gov.br/index.php/comunicacao/noticias/2831-desintrusao-doajarani?highlight=WyJwcm90ZVx1MDB1N1x1MDB1M28iLCJ0ZXJyaXRvcmlhbCIsInByb3RlXHUwMGU3XHUwMGUzbyB0ZXJyaXRvcmlhbCJd

http://amazonia.org.br/2013/12/mpfrr-funai-realiza-desintrus\%C3\%A3o-de-fazenda-da-regi\%C3\%A3o-do-ajaranina-terra-yanomami-em-rr/ 
contado em a Queda do Céu (KOPENAWA; ALBERT, 2015), demonstrando uma continuidade entre a montagem do programa de educação da CCPY, um projeto de Davi Kopenawa, e a criação da Hutukara onde se verifica um desafio de, nos diálogos internos, manter a busca de consenso, e na lida com a política externa, a lógica política do convencimento para angariar aliados e simpatizantes, e um enfrentamento claro dos problemas que afetam a Terra Yanomami. Evidencio haver, da mesma forma em que separaram educação escolar de educação yanomami, um discernimento sobre essas duas formas de relação política: horizontalizada entre yanomami e tratando com a alteridade, sempre pelo convencimento, consegue ajuda dos brancos para defender a sua terra. Davi é frequentemente questionado e posto a prova pelos seus pares Yanomami, especialmente de outras comunidades; tem assim esse desafio de apenas tratar horizontalmente, sem uma relação de coerção ou autoridade internamente; externamente, como é de se esperar, a Hutukara é obrigada a atuar no âmbito das políticas de Estado, cobrando a autoridade da lei que lhe garante a legitimidade de sua condição diferente; uma diferença a legitimar a manutenção de sua terra floresta. Aposta assim na verticalização da lei escrita, a subordinar a todos os da sociedade de Estado. Sztutman (2011) apresenta a potencia do pensamento clastreano como sujeito a atualizações frente à relação com o Estado. Tem sido o Estado o instrumento de salvaguarda dos Direitos indígenas e de minorias. Embora seja paradoxal quando lemos no Etnocídio (CASTRES 2003) ser o Estado sempre etnocida.

Os discursos analisados nos permitem dialogar com algumas abordagens em construção de uma antropologia reversa, onde o "nativo" analisa seu pesquisador e sua sociedade. Sobre as competências Yanomami e a criação de um corpo maior de pessoas capazes de navegar nos dois mundos, analiso nisso o papel do indigenista, daquele que aceita participar da estratégia do povo, em suas competências de tradução entre mundos. E cujas competências como educador tratará de desvendar as ferramentas e aparatos técnicos e conceituais da nossa própria sociedade; é a matemática, os equipamentos... e através desse domínio há uma etnografia às avessas, que lhe permite contato com o outro em suas socialidades tanto urbanas, em suas visitas à cidade, como no posto, na floresta, onde o auxiliar de saúde, numericamente minoritário, serve de referencia de como decifrar os brancos, de poder analisar cada mínimo sinal gestual como indicador de suas posturas frente ao outro. Nisso se esclarece a existência de uma dimensão não normativa, em que se travam cosmopolíticas com parâmetros distintos, em que o gestor de uma associação tem para si o desafio de navegar em ambas. Os Yanomami tem demonstrado competência em garantir a integridade do território 
urihi, nesse capítulo, circunscrito à questão da invasão fazendeira no Ajarani, apesar das ameaças que os cercam. Isso em grande parte, se deve a Davi traduzir o mundo dos não Yanomami sobretudo para os mais velhos, mas também incorporado aos hereamu, falas noturnas em que explica os desafios de sua luta. Toda a comunidade, o seu grupo local, está ali, ouvindo. Sua capacidade de tradução de mundos, talvez se deva a Davi ter-se primeiro metamorfoseado de branco, em aprender sua língua, visitado todos os espaços possíveis a que foi chamado, em condições tão diversas de, tanto subalternamente limpar piscinas para mais ricos, na juventude, quanto ser posteriormente aclamado por multidões de jovens interessados em suas palavras. Para depois retornar e contar aos Yanomami como é esse mundo e quais o seus perigos. Uma atitude que na minha opinião lembra a equivocação controlada que nos propõe Viveiros de Castro (2004), referindo-se ao trabalho do xamã no mundo dos espíritos xapiri, em que é necessário mergulhar no devir onça sem confundir-se com ela. Essa comparação foi feita por Jose Kelly (2005) e está no cerne do seu trabalho. Advogo aqui que Davi soube experienciar esse mergulho; e o fez tão bem que, embora nesse capítulo e no âmbito da Hutukara Associação Yanomami esteja preocupado com a terra Urihi dos Yanomami, em A Queda do Céu, Davi deixa claro que esse hábito de dividir a terra em pedaços tem a ver com a "sociedade das caixinhas" (nós, as sociedades de Estado), e tenta convencer aos napëpë da necessidade de mudar nosso modo de vida e de produção, para proteger a floresta toda, o planeta Terra por extensão.

Sustento a tese de a inteligência espacial dos Yanomami estar coerente com o observado na relação com a contra mestiçagem e a teoria de virar branco (KELLY, 2005; 2016), onde há um movimento cuja intencionalidade está na sua autonomia, num afastamento da tendência à concentração, em grande parte causada pelo posto. Nos capitulos seguintes, veremos algumas dimensões e implicações da elaboração espacial Yanomami, desde sua relação com a floresta, sua abordagem política, e estudos sobre a mobilidade revelando uma resistência a processos inerentes ao contato, como a sedentarização. 


\section{Mobilidade Yanomami e Construção da Paisagem}

\section{Introdução}

O conceito de paisagem tem sido usado indiscriminadamente em diversos trabalhos geográficos talvez pela sua polissemia, pela amplitude que o envolve. Estando no título, explicitar o entendimento para este trabalho torna-se uma obrigação. Sem alongar nos conceitos já plasmados, importa a implicação em nela reconhecer ou não o sujeito à qual ela interessa, e as relações e interações nela produzidas. Interessa também considerar se a paisagem é apenas algo externo ao sujeito, ou está também no sujeito que a vê, pensa, percebe. Se nesse capítulo há uma sobreposição entre fenômenos observáveis, enquanto relações, os povos constroem suas paisagens levando em consideração o que percebem ali, as teorias nativas de paisagem, suas cosmologias, e sobretudo as relações com outros sujeitos não-humanos (para nós), mas que podem ter significados humanos no compreender dos Yanomami. Disso se vê que o entendimento de paisagem utilizado pode implicar no conceito de ciência, de como se conhecem os fenômenos. Na nossa abordagem cosmológica da ciência ocidental, natureza e cultura, sujeito e objeto são diferenciados, sendo a natureza externa à cultura, a paisagem é vista como objeto externo dotado de características, processos e "funcionamentos" (fisiologias); em certos momentos, esse capítulo apresentará essa lógica conceitual de paisagem. Mas as dinâmicas tratadas aqui, envolvendo as ações humanas, possuem implícitas intencionalidades responsáveis por influir na produção do espaço, utilizo então o conceito de paisagem como similar ao 'meshwork' ingoldiano (INGOLD, 2011), inspirado em Lefebvre (1991), como a resultante de uma malha onde se conectam seres, através de relações e eventos que se entrecruzam. A paisagem enquanto escala de abordagem do sujeito possui essa característica de permitir um certo embaraçamento entre natureza e cultura, onde tais fronteiras se atenuam (MARIA, 2016). Ainda, almejo um terceiro uso e entendimento da paisagem, sendo a autopercepção integrada no ato de habitar pelos Yanomami, incluindo os seres existentes no seu mundo cosmológico. Como síntese dessas possibilidades, proponho dar liberdade para manusear o conceito de paisagem conforme as necessidades de cada objetivo expresso no conjunto da tese.

O conceito urihi é igualmente polissêmico, podendo significar floresta, terra, território; talvez, sendo isso uma tentativa de tradução, poderíamos subverter o conceito de território 
para "a terra a qual se pertence", pois quando utilizamos a expressão "witi pii urihi wa tha?" ou "witi pii urihi wa piria tha?" estamos perguntando 'de qual floresta você é?' Ou 'qual floresta você habita', sendo que 'piria', habitar, é a mesma palavra para deitar-se na rede, havendo novamente uma correspondência polissêmica entre ambas as traduções, e indicando o quão transitório pode ser esse local, para os yanomami, além do conceito de território como apropriação de um povo, temos um povo pertencendo àquela terra, consonante às perguntas aqui relatadas.

Temos nesse capítulo o desafio de discutir algumas práticas Yanomami com um enfoque distinto do capítulo anterior. Ao afirmar no título que os Yanomami constroem paisagem, merece ressalva: não se trata de demonstrar que plantaram a floresta amazônica, mas, a exemplo de outras sociedades ameríndias, exercem sua coexistência com os outros seres da floresta, transformando-a. Como já explícito, os processos de maior impacto na paisagem, atribuído às roças e à própria morada resultam em uma clareira a se regenerar e produzir assim uma floresta renovada e ao mesmo tempo enriquecida com novos elementos do agroecossistema e das coletas ali levadas, onde se incluem árvores e plantas permanentes. Com o devido sentimento de pertencimento à floresta, com uma experienciação de difícil tradução, objetivamos aqui colocar em questão parte do modo como a ecologia cultural vinha construindo seus argumentos, muito apegados ao determinismo, a uma primazia do meio sobre as pessoas, e uma crítica à sociobiologia com teses igualmente deterministas sobre as sociedades humanas. Convém aqui a tentativa de observar a convivência dos Yanomami como fenômenos, com uma perspectiva multidimensional; fazer da ciência uma mera predição de fatores causais seria algo empobrecedor, frente à admissão de uma simultaneidade entre êmico e ético, e transcendendo tal discussão nos permite colocar em questão nosso próprio constructo de natureza e cultura que fundamenta nossa ciência. Antes, porém, cabe aqui termos a liberdade de especular sobre o observável nas florestas habitadas pelos Yanomami, em busca de coerência.

Os Yanomami, bem como os povos indígenas, tem sido tratados teoricamente com base em ausências. A explicação sobre a relação com a floresta é exemplar: 'Os Yanomami não alteram mais a floresta porque não possuem tecnologia para tal', 'o que os move pela floresta é a escassez' são alguns dos argumentos com base numa visão reducionista de ciência ecológica. Sobre a questão dos fatores limitantes, argumento propagado pela ecologia cultural, Albert (1985) não desmente a existência de limitações, mas critica o contorsionismo 
sofismático de tentar definir o comportamento Yanomami (e de qualquer outro povo) como uma "resposta adaptativa" aos fatores limitantes. Os fatores limitantes parecem funcionar como uma abordagem econômica da vida, num reducionismo de fator único; no caso dos Yanomami, cada nova variável (infanticídio feminino, guerra) obrigava a encaixa-la como parte da equação, o que resultava explicar muito pouco. As estratégias adaptativas dos Yanomami vão muito além da guerra, implicando em usos de recursos e alternativas proteicas, alimentares, ou outras, bem como uma vida satisfatória no contexto em que materialmente vivem, melhor explicado por Sahlins (1972) em original affluent society; um debate nesses termos, em analisar e tentar explicar uma sociedade pela escassez, pela ausência, mostra-se muito mais uma explicação ideológica de sustentar alguma racionalidade em nossa própria sociedade de Estado. Ao contrário, Bruce buscou a racionalidade do sistema ritual Yanomami, explicando assim a guerra, a concepção de doença e morte, e a dinâmica intercomunitária de alianças e rivalidades dos Yanomami. Em campo, pude perceber as explicações Yanomami a respeito de mudanças de localidade, e os conflitos tinham grande relação com o dito sistema ritual. Sem negar outras explicações para a mobilidade (RAMOS, 1993).

As novas descobertas sobre a ocupação da Amazônia pré-1500 tem contribuído para esse questionamento do constructo natureza e cultura. Betty Meggers (1977) desdenhou a pujança Amazônica e propôs haver fatores limitantes à sua ocupação, essa tese então vigente foi questionada por Ana Roosevelt (1980; 1991), com base na existência pretérita de grandes sociedades por ela denominada de cacicados na região do Tapajós. Outros aportes arqueológicos trouxeram outras perspectivas, bem como a etnologia também contribuiu para modificar esse entendimento sobre a Amazônia. Uma das contribuições veio do trabalho da química Dirce Clara Kern (KERN; KÄMPF, 1989) as denominadas terras pretas de índio da Amazônia são reconhecidas como antropossolos, originados da ação agrícola humana. A etnoecologia, bem como certos elementos da agroecologia amazônica passam a ser utilizados como marcadores da dispersão humana da Amazônia; a paleopalinologia associada aos sítios de terras pretas indicam uma estratigrafia de grãos de pólen cuja abundância revela como a atividade agrícola (principalmente pólen de milho) assume sua dinâmica própria e em 1500 ela praticamente desaparece da maior parte dos sítios estudados (BUSH; SILMAN, 2007); a descoberta demonstra claramente ter havido um despovoamento (provavelmente por epidemia) considerável a partir de 1500 . Novas descobertas no campo da agroecologia, além da pupunha (CLEMENT; RIVAL et al., 2009), outras plantas passam a ser interpretadas como de necessária dispersão antrópica: a castanha da Amazônia (Bertholetia excelsa), usualmente 
possui populações concentradas em castanhais (SCOLES; GRIBEL, 2011; SCOLES; GRIBEL et al., 2011), isso denota a participação das populações ameríndias pré-1500 na distribuição dos castanhais pela floresta amazônica. Trata-se de uma reorganização teórica de grandes implicações para vários entendimentos anteriores sobre as populações ameríndias. $\mathrm{O}$ trabalho de Scoles tem inspiração no de Balée (1994), sobre os Urubu Kaapor como prováveis dispersores da Castanha da Amazônia (Bertholetia excelsa). William Balée funda a Ecologia Histórica, propondo uma releitura da História "natural" Amazônica a partir da presença humana (BALÉE; ERICKSON, 2006; BALÉE, 2013). Meu trabalho de mestrado veio a se somar a esse corpo teórico, no âmbito das ciências ecológicas. As clareiras e seu processo dinâmico de regeneração, apresentando uma sucessão de espécies muitas das quais úteis aos Yanomami definem esse processo regenerativo na forma de um distúrbio intermediário (do ponto de vista da ecologia), e também como uma obra Yanomami. Essa marca própria dos Yanomami produz sistemas específicos dentro da floresta que, veremos, tem nas suas características algumas notadas e aproveitadas pelos Yanomami. Essa condição traz a possibilidade de pensar a floresta como um locus de influência espacial humana, e cujas interferências trazem de volta à discussão sobre a coexistência humana com outros seres, compreendendo a paisagem como essa malha de relações multiespecíficas. O aproveitamento dessas características direciona a reflexão para uma intencionalidade, nessa relação de convívio com a floresta.

\section{Os Yanomami e a floresta amazônica.}

Vários conhecimentos dos Yanomami sobre a Amazônia vêm sendo reportados em obras de Lizot, Milliken \& Albert, Colchester entre outros. A obra de Milliken \& Albert (1999), a Forest People, revela uma grande quantidade de plantas e espécies, cultivadas e utilizadas a partir da coleta nas florestas, corpos d'água e capoeiras. Lizot (1980) descreveu a roça Yanomami, desde sua abertura até a regeneração, bem como sistemas de caça.

Pretendo nesse capítulo revisitar registros onde a mobilidade característica dos Yanomami lhes confere um papel de bioconstrutores da floresta que habitam, implicando em dispersão e favorecimentos de espécies vegetais, alteração de certos ambientes, podendo mesmo interferir na dinâmica de crescimento de elementos da fauna por eles utilizadas, favorecendo sua reprodução e dispersão. Vou apresentar formações ecossistêmicas oriundas de variados lugares da TIY, onde vários sistemas guardam evidências de terem sido alterados por humanos. Através de uma análise geográfica e de dados etnográficos, poderei refletir 
sobre essa idéia central de que os Yanomami constroem uma paisagem diferenciada, e que a floresta não deve ser interpretada segundo a lógica de um receptáculo natural de populações humanas, mas co-evoluiu com essa presença. Trata-se de uma investigação em caráter ainda especulativo, tais comportamentos dos Yanomami se dão sem a existência de qualquer poder central; é estruturalmente essa conformação, com a ação de vários indivíduos autônomos, que produzem a paisagem resultante, de grande movimentação em novos sítios acabando por desenhar a floresta em um mosaico de regenerações. Em minha experiência entre os Yanomami, sobretudo quando caminhando pelas florestas, registrei diversos eventos que marcam a constituição da floresta pela presença humana, evidências essas, muitas vezes discretas; pretendo apresentar esses ambientes diferenciados, com marcas de intervenção humana, associados ao conhecimento e documentação sobre o modo como vivem, pensam e agem os Yanomami, suas habilidades em lidar com a floresta e a análise geográfica, numa tentativa de sistematização. Os eventos tratados aqui são, além de localidades onde se encontram espécies com particularidades, visitas e conformações de sítios antigos de moradia, modos de distribuição de roças e cultivares, práticas relacionadas ao cultivo de roças, concentrações de espécies vegetais etc. As habilidades observadas estão relacionadas às escolhas de locais de caça, aos cuidados com roças, às habilidades nas intervenções com as espécies utilizadas e a distribuição espacial encontrada. Inicio o trabalho com casos na bacia do Alto Demini, com os Parawau, especificamente o Koherepi, reuno as redes de relações com exemplos do Alto Demini (Toototopi) e suas relações com o Alto Orinoco e Homoxi, já na bacia do Alto Mucajaí. Por fim, relato alguns conhecimentos e estratégias espaciais com roças de uma família do Auaris.

\section{Estudos de caso}

\section{Especificidade de alguns locais: concentrações de árvores}

A floresta tropical biodiversa apresenta raros agrupamentos de árvores da mesma espécie, quando encontrados sugerem ser consequência de manejo, de práticas dos grupos humanos no aproveitamento de seus frutos; informações dos Yanomami chamam atenção para a construção histórica da paisagem, a ser enfrentado com métodos etnográficos, arqueológicos, e geográficos.

As concentrações de jatobás arokohi (Hymenea courbaril) no alto de uma serra no Parawau, uma parte geográfica identificada pelos Parawau teripë como de importância histórica, por ser um dos acessos para a descida da serra de onde vieram. Nessa rota, passa-se 
próximo de uma imensa cachoeira, quando o Rio Demini adentra a baixada, num degrau final da serra, registradas nas cartografias do Brasil como Cachoeira do Tamanduá (Yaripora). Para Atapai, o ancião que me orientou, ela se chamava 'xamatua pora!' Nem todos os outros Yanomami concordavam, riam da denominação (por saberem a etimologia - cachoeira do Tamanduá, como chamavam os napëpë), mas ele contou mais sobre a região, sobre os napë que estiveram ali perto (comissão de limites, que teriam sido contatados pelos atuais habitantes da Cachoeira do Aracá). A Figura 5 apresenta um mapa retratando essa região do Alto Rio Demini, onde concentram-se alguns grupos Yanomami, e de onde se sai rumo à referida cachoeira. Na imagem é perceptível uma faixa mais clara e recortada, à oeste, representando as escarpas dessa serra.

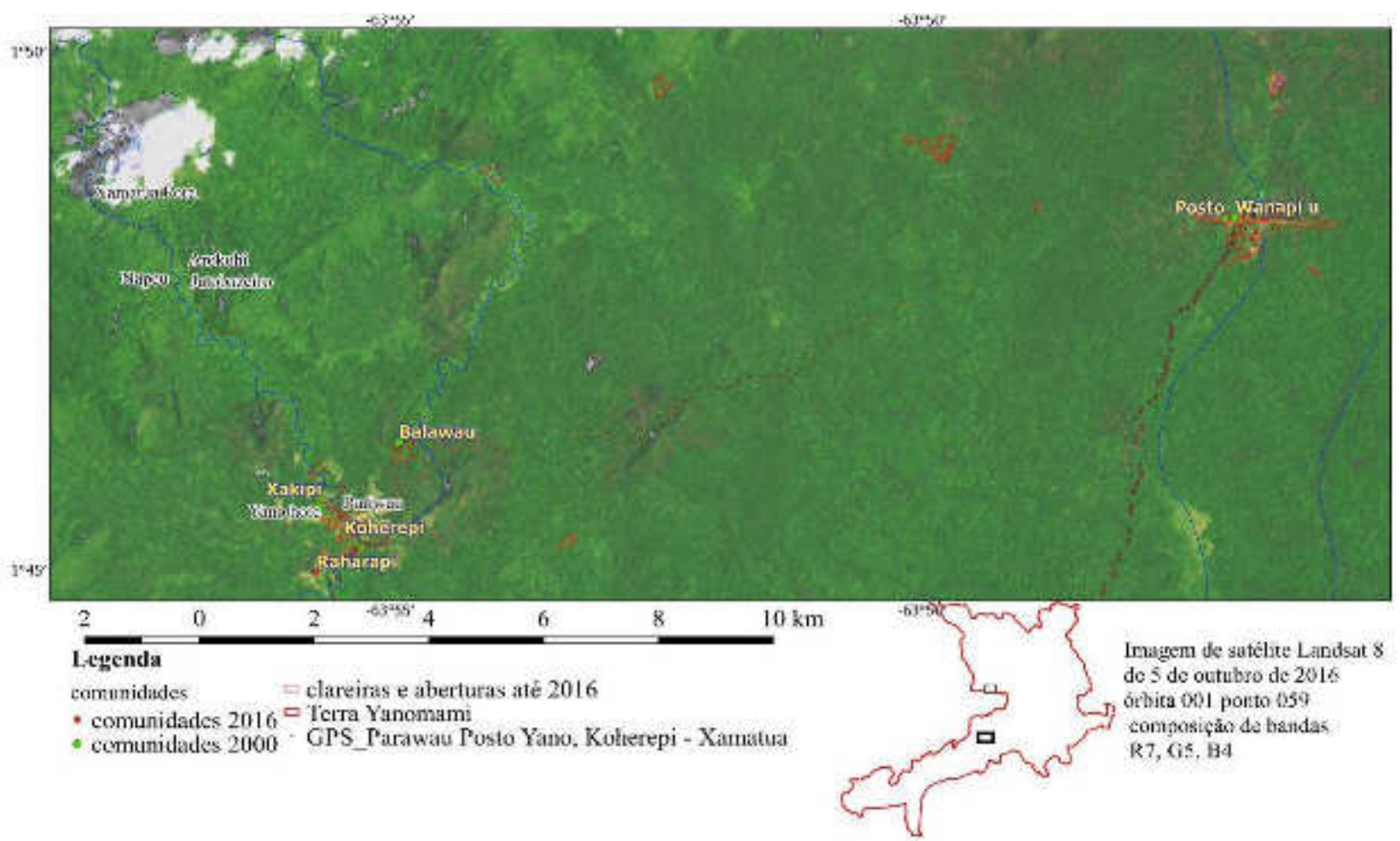

Figura 5: Mapa da região do Parawau na Terra Indígena Yanomami, incluindo as cabeceiras do Rio Demini, onde está a cachoeira "Xamatua" (Tamanduá) e em suas proximidades, as concentrações de jatobazeiros arokohi (Hymenea sp.).

No Parawau, uma região de encontro de grupos Yanomami de origem distinta, o atual Koherepi se caracteriza por agrupar três grupos formadores, que ainda mantém para si suas diferenças de origem; são eles o Koherepi, o Xakipiwei e o Xotokomapi (PEREIRA, 2007); a não unanimidade é explicável pela origem multicomunitaria e pelo fato de haver uma diferença de recorte com os mais jovens. Os jovens da idade dos professores, por já possuírem uma vivência de escola e compreenderem diferentemente a ideia de napë como exclusivo aos 'não yanomami', enquanto os anciãos tratavam outros Yanomami como napë no sentido de ‘inimigo’ (algum que não pertencessem aos co-residentes, ou aos seus aliados, estreitando os 
limites dos aliados e impondo, dentro do universo Yanomami, ainda, o conceito de alteridade).

Concentrações de árvores da mesma espécie, com um dossel de idade semelhante, mais uma proliferação de plântulas de outras idades, sugere paisagem construída, como já pude presenciar em ecossistema de cerrado com os A'uwe Xavante, contribuindo para o reconhecimento da ocupação indígena A'uwe Xavante em Wede'dze (WELCH; COIMBRA $J R$ et al., 2013). Mas tal evidência de ocupação humana se soma a uma constituição da paisagem propícia a fazer parte da história desses grupos Yanomami, os diversos grupos que se juntaram e formaram os Parawau teripë; quando os visitei, o grupo que agregou maior variedade de comunidades de origem (quatro) foi o Puriwau (na denominação do mesmo ancião morador), conhecido como Koherepi teripë. Essa região, próxima à morada em 2006, teve importância na descida da serra de muitos grupos, os Koherepi, os Xakipi, Xotokomapi. Os três grupos compuseram essa aliança com os Wanapiu e o conjunto foi o principal habitante do Posto Yano, um posto construído em 1995 com recursos internacionais de apoio à causa indígena onde essa aliança se consignou. $\mathrm{O}$ posto Yano está a 6-8 horas de caminhada do Toototopi, local de origem de Kopenawa. O local de residência mais constante e marcante dessa população fica na região do Alto Demini (Parawau), não na região do Posto Yano, servido por um pequeno curso de água (Roahikatiopëu), ali era uma moradia mais recente, onde permanece apenas o grupo Wanapiu. Entre 1995 e 2000, moraram ali esses quatro grupos e um grupo de língua yanomae os Hayasiki, em discórdia com os outros, acabando por ser uma constante relembrança de possibilidade de revanches (RAMALHO, 2008). Voltaram no início do século XXI para a região do Alto Demini que vínhamos descrevendo. Os jatobazeiros Arokohi agrupados fazem parte de uma relação mais antiga de povos indígenas e aquela região onde se localizam; onde também fôra morada de antigos, e é conhecida com diferentes nomes pelos grupos: Kapirota para uns (grupo dos Wanapiu), Parawau, para outros, e agora Puriwau para alguns...

O contexto maior dá àquela concentração de árvores um caráter especial, mesmo sem ter sido produzido nessa geração. Tais concentrações podem ter origens em variadas formas, mas essencialmente, o aproveitamento de uma coleta desse fruto, pode gerar uma expansão dessa árvore útil, à maneira como são reconhecidos os castanhais (SCOLES; GRIBEL, 2011). Os jatobazeiros eram reconhecidos pela comunidade e visitados para colheita, ou atração de caça, em passado recente. 
É plausível pensar que os Yanomami (ou outro povo anterior a eles) coletaram e consumiram os frutos de arokohi Hymenea courbaril em sua residência e que aquele adensamento de árvores da mesma espécie pode ser um sítio de moradia pretérita. Mas adensamentos podem ser oriundos de rotipë, pequenas clareiras, por vezes imperceptíveis, onde se reúne e se descansa na empresa de uma caminhada. Rotipë representa uma referência espacial de quando um local torna-se mais habitual. Há outras formas de pouso no mato, onde alguns locais gozam certa preferência, acampamentos de pernoite em longas distâncias, em geral próximo a fontes de água. Nas regiões de serra, a coleta das castanhas de seringueira branca (Micranda rossiana) momokiki, os locais onde habitualmente limpam as cascas dessa euforbiácea acabam por facilitar sua brotação concentrada nessa localidade. por ser uma planta dependente de preparo para retirar a toxicidade, os Yanomami coletam grandes quantidades de uma vez, as mulheres com seus cestos witpë mobilizam-se intensamente.

O tratamento de edibilidade retirando os venenos consite em lava-los por dias no rio, processados e armazenados em cestos sakosi (15 litros, aproximadamente) dentro da correnteza do rio. Alimentos com alto processamento como os wapu kiki nas terras baixas e o momo kiki nas serras horepë demonstram uma relação forte com o fogo pelo tempo de cozimento alternado aos banhos de rio. Permito-me especular um diálogo possível com o lançamento da neurocientista Herculano-Housel, sobre o papel do processamento dos alimentos na diferenciação da atividade cerebral dos humanos, dentre os quais está o domínio do fogo.

O domínio do fogo remete à história mítica do $\operatorname{Iwari}^{16}$, a entidade humana jacaré, casado com uma rãzinha hwrahwramari; história repetida encenada (LIZOT, 2007). Iwari é o jacaré em cuja boca guarda o fogo, o único a possui-lo, e os outros, descobrindo-o comer o alimento assado, investiram em quebrar o monopólio e eles o fazem rindo. Relaciono a historia do iwari, com um poder na forma de um monopólio um equivalente da condição de se sobrepor aos outros pela avareza. Dá por sua vez a dimensão da importância do fogo do processamento dos alimentos para a humanidade; e por extensão na produção do alimento, na roça, a dimensão fundadora da humanidade numa luta contra a avareza. Os pré humanos (uma massa indiscriminada de humanos-animais não separados) conquistam o fogo, utilizando estratagemas hilariantes e assim obrigaram ao jacaré abrir a boca. Uma sabotagem ao um,

16 Iwari é a entidade mítica do jacaré, que detém o fogo, uma coincidência curiosa com os dragões de mitologias euroasiáticas, de um réptil mítico associado aofogo. 
representado aqui pelo monopólio do fogo, impedindo a humanidade; a transformação também se deu no interior dos humanos tornarem-se mortais. Através da queima se realiza a depuração cósmica do morto, fomentando sua consumação (no reahu) ${ }^{17}$ (ALBERT 1985:417420). E através do fogo também se constrói a floresta, nas diversas clareiras, antigas roças e moradas, semeadas, enraizadas por diversas plantas relacionadas à coleta na floresta e à vida social dos yanomami. São elementos organizados por essa relação com o fogo transformador, reunindo escalas, dimensões (simbólicas, cosmológicas, cotidianas) e tornam-se indissociáveis entre si, e todos da maior significância para os Yanomami.

É comum observar sementes brotando nos locais atrás da yano residência circular, onde costuma-se depositar o lixo, resto dos processamentos de variados 'vinhos' de palmeira, caldos feitos da polpa amolecida de frutos de palmeira, dos quais o açaí maimahiu (Euterpe precatoria) é o mais famoso, mas incluem-se as abacabas hokomahiu (Oenocarpus bacaba), as patauá koanarimahiu (Oenocarpus bataua). Essas, se deixadas, podem tornar-se novas palmeiras. Isso pode, anos depois ser observado como evidência de um local de moradia. Nesses casos não se trata da presença da planta em si, mas da configuração espacial que sua presença adensada provoca.

O espaço da roça e da residência é uma área privilegiada pelo afluxo de frutos e suas sementes, trazidos nos cestos wï pë (wï - cesto, pë plural) e o repovoamento amplia a possibilidade de ali ser uma concentração de árvores de apiahi (Micropholis melinoniana) Asowasi kiki (Pseudolmedia laevis) oruxihi (Anacardium giganteum) e tantas outras variedades de frutos amazônicos presentes na alimentação humana e da fauna. A contribuição humana de sua coexistência de frutos foi tratada estatisticamente por Levis et al. (2016), demostrando uma causalidade entre a hiperdominância de espécies utilizadas pelos povos ameríndios (aos quais incluem-se o açaí e outras espécies citadas aqui como alimento, acrescido do breu branco warapakohi Protium sp, sempre úteis e presentes para os Yanomami), e o exemplo yanomami e seus frutos coexistentes, sugerem que a relação de longa data pode ser responsável pela hiperdominância. Sua utilização é um favorecimento

17 Reahu é o cerimonial final realizado por causa de um lider morto; última vez a se referirem sobre ele seus feitos, e dia ca consumação das cinzas pelos designados. Já ressaltado por Albert na narrativa dos acontecimentos, o fato de o reahu ser irredutível a "cerimônia dos mortos", significando um evento social, uma festa (Dalmonego 2015) 
pela convivência, convém pensar numa coexistência, onde o molde da intencionalidade humana indifere do encanto do fruto. O conceito de coexistência deriva da ideia de agência de outros seres vivos sobre nós, como planta companheira, trabalhado por Anna Tsing (TSING, 2015), produzindo reflexos em pesquisas de autores recentes no Brasil (CAMPOS, 2016; CARDOSO, 2016).

A parte seguinte abordará contribuições Yanomami à paisagem florestal dimensionandoa à sua lógica reticular, a das redes de alianças e sua evidência mapeável, das trilhas de interligação. Embora eu me apoie na lógica da domesticação da pupunheira, as modificações por seleção ao longo da história conjunta com populações humanas ameríndias (CLEMENT; RIVAL et al., 2009), caberia indagar se o termo domesticação é o melhor conceito, à luz da releitura proposta por Anna Tsing, onde cereais satisfatoriamente domesticaram humanos. Seguro de não encontrar similar disso na cosmologia Yanomami, onde a domesticação é parte do processo de humanização, numa lógica perspectivista (LEITE, 2013), mas, a levar essa proposta a sério, a 'cultura', as regras socias a etiqueta está para a filosofia indígena no eixo do dado, do inato,enquanto a 'natureza' é que corresponde ao eixo da transformação; e considerando a agência da planta sobre os humanos, justificaria considerar especulativamente essa abordagem.

\section{Domesticação e redes de alianças}

A rede de alianças intercomunitárias (ALBERT 1985:), central na organização social Yanomami, e no provimento das comunidades nas suas necessidades (sobretudo matrimoniais), também tem um reflexo na paisagem sobretudo pela sua espacialização mais explícita, as trilhas que interligam as comunidades e podendo gerar, segundo o mecanismo expresso acima, uma influência na constituição da floresta, por favorecer as espécies significativas.

A simples presença de uma espécie pode indicar o sítio antigo de moradia, por ser oriunda de cultivo; o caso mais notório é a pupunha rasasi (Bactris gasipaes), pesquisado por Clement, pela sua importância no estudo da dispersão das populações pela Amazônia (CLEMENT; RIVAL et al., 2009). As pupunheiras rasasi são plantadas ao redor das residências, às vezes também nas roças, sendo um indicador de moradias pretéritas. É muito comum espécies cultivadas em um sítio de moradia persistirem por décadas, e ser reconhecido por outro grupo que por ora ocupa a região. Testemunhei isso na região entre o Homoxi e as 
cabeceiras do Orinoco, já na Venezuela. Ehereximipiu era o nome do grupo que construiu casa e roças ali, tendo migrado como alternativa à ausência de condições no lado brasileiro, tomado de grotas, lagoas e cascalheiras delegadas aos moradores originários, os Yanomami. Terminado o garimpo, com a demarcação, as pistas Pedro Jacarandá, Jurubreve, Oliveira, Macarrão, Jeremias, Chimarrão, Bahiano Formiga, Pau Grosso e as cavas formaram uma faixa de destruição acompanhando o Alto Rio Mucajaí, por considerável extensão (MILLIKEN; ALBERT et al., 2002; LE TOURNEAU; ALBERT, 2010). Todas essas pistas, mais algumas ao redor, serviram ao garimpo que destruiu as cabeceiras do Rio Mucajaí, o Uxiwau(veja o capítulo 6, sobre o tema e região).

Ali, antes disso, moraram os Homoxi theripë (hoje, Yaritha/ Wiramapiu theripë), ainda tiveram outros pousos intermediários no caminho. Não significa que a região seja inabitável pela falta de recursos: os kahusiki, fruto de uma cecropiácea (Cecropia Sciadophylla) que produz infrutescências saborosas para os Yanomami, veados hayapë cruzam a região, mas não há palha yaahanaki (Geonoma sp.) para cobertura de casas, nem local com solo para sustentar boas roças. Uma das razões apontadas pelos Yanomami do Homoxi para sua mudança para Ehereximipiu, Arakititiopëu e Wahapiu, foi a presença de nëropë, que eu traduziria por fertilidade, condições de solo para se fazer roça. As roças são feitas nas encostas dos morros, já em região serrana. Nos mais variados estudos que observei a produção de roças em serra ocupa um sopé de morros, aproveitando os cones aluviais de decantação, que estabilizam o desnível e possuem solo um pouco mais profundo. É o padrão em quase todo Surucucu e Serra Parima. Mesmo sem condições satisfatórias, a ocupação no Homoxi pelos Yanomami permaneceu, em parte por manter a ocupação da terra, local realmente tradicional, onde já habitaram diversos sítios, e ainda os denominam, o Tototopi, o Apiahipiu, o Xereu, habitado após o garimpo, em rota de fuga das áreas alteradas do Alto Mucajaí (Uxiwau), para o sul (ver capítulo VI). E mesmo o persistente grupo que habitava próximo ao posto de saúde, já possuia sempre uma segunda residência 'na Venezuela'; foi, por fim, o destino da maioria, mantendo apenas a posição com o posto no Brasil, para ter assistência à saúde, acesso aos napëpë (fonte de utensílios matehipë). Dentre essas comunidades, estão a primeira, o Yaritha, já citado, e o Ehereximipiu, que eram os Uxiwau theripë; esse grupo, em sua nova moradia encontrou exemplares velhos de pupunheira Rasasipë (Bactris gasipaes), e identificaram ser dos amigos, dos Yanomami do Toototopi, cuja rota de descida se deu por ali. Foi Romão, morador do Ehereximipiu quem nos mostrou, na clareira da nova roça deles. Assim, temos uma situação em que um Yanomami ocupa um local de capoeira de antiga roça hutuwãropata (lit.: roça 
homem velho), mesmo sem ser o primeiro ocupante da localidade, a muito tempo sem presença intensa. Mas Homoxi theripë e Toototopi theripë se visitam, são aliados, apesar da surpreendente distância em que se encontram. Ambos estão no Brasil, mas separados pelas cabeceiras do Orinoco, o Harau, alguns dias de viagem. Sendo que parte dos sobreviventes de Haximu, habitam hoje o Toototopi, já com alianças matrimoniais. Haximu é um grupo comunitário que em 1993 sofreu um massacre (MARIZ-MAIA, 2001), com 16 assassinados, realizados por garimpeiros que dominavam a bacia do Alto Mucajaí (Uxiwau).

As características geográficas dos locais ocupados por esses grupos são essencialmente diferentes: enquanto o Homoxi permanece a altitudes da ordem dos $800 \mathrm{~m}$ (a.n.m), o Toototopi já se encontra em terras baixas da Bacia do Rio Demini, que vertem para o Rio Negro. No Toototopi, bem como no Demini, encontrei o uso de óleo retirado da árvores da copaíba, narauhi (Copaifera sp.), utilizada como base para pintura; sua ocorrência delimita as regiões de altas altitudes, tais como o Homoxi. Provavelmente, a copaíba utilizada para pintar meu rosto no Demini foi trocada com habitantes de Toototopi, velhos aliados, que por sua vez adquiriram de seus aliados do Homoxi e do Harau, nas terras altas dos interflúvios OrinocoRio Mucajaí (Harau- Uxiwau). Curiosamente, essa amplitude geográfica está contemplada no mito do iwari, relatado acima: ao final do mito, indignado com a apropriação do fogo, a rãzinha hwrahwramari joga-se na água e foge rio acima (yamoahuruma), amaldiçoando-os (essa rã só se encontra nas serras, em regiões encachoeiradas) enquanto o jacaré Iwari, separando-se de sua ex-cônjuge, também se atira na água rio abaixo (wereahuruma) e o jacaré é característico das terras baixas, na Amazônia.

A rede de relações revela também movimentos relacionados a fugas de epidemias, à deterioração socioambiental produzida pela atividade garimpeira, embora, mesmo nesse caso, mantenha a lógica Yanomami responsável pela dinâmica das alianças intercomunitárias (ALBERT 1985). Longe de serem aleatórias, as escolhas de lugares e as rotas assinaladas mantém vivas uma rede de relações que corroboram a idéia de um transecto, de um continuum de ocupação, aproveitando posições com características diferentes. Do ponto de vista da paisagem, as redes de relações podem ampliar parcialmente as relações benéficas às especies significativas, cuja parte originalmente florestal goza de hiperdominância no conjunto da floresta amazônica.

As trocas de favores e bens materiais implicadas nessa rede de relações se beneficiam 
das características dos espaços vividos, pois alcança os grandes rios das terras baixas, aqueles descritos como passíveis de suportarem povoações maiores (CLEMENT; DENEVAN et al., 2015), eles se incluem nas redes de relações um continuum envolvendo habitantes de tais regiões de terras baixas, bem como aqueles dos interflúvios, que a princípio caracterizariam os Yanomami, embora esses também ocupem as regiões de terras baixas. Nessas terras baixas onde habitam, no Demini e no Toototopi, observam-se indícios arqueológicos tais como oficinas líticas (desgastes em rochas em formações de pratos e outros baixo-relevos relacionados a afiar machados e outras ferramentas líticas) que os Yanomami não reconhecem como originados de seus ancestrais - provavelmente algum outro povo carib ou arawak. Se no passado a presença referia-se a outro povo, em termos de função e dinâmicas espaciais, as redes de relações hoje presentes sugerem uma certa continuidade.

Em diversos pontos das trilhas que servem historicamente aos deslocamentos nessa região há testemunhos das interferências na paisagem pelas populações ameríndias (na Figura 6 apresento um mapa com alguns desses lugares e as redes de trilhas): no atual Xiroxiropi, no sopé das serras, concentrações de cacaueiros porounahi (Theobroma cacao) indicam prováveis moradias no passado, numa rota histórica de descida para as terras baixas. Dos vários grupos que hoje habitam o Toototopi, registrei pelo menos três levas migratórias por essa faixa, que depois acompanham o curso do Paxotou (os militares e comissões de limites que mapearam a região no passado denominam esse curso de Rio Cunha Vilar).

A associação das redes de relações e intercâmbio com tais interferências na paisagem tornam este um universo rico a ser estudado. Sabe-se que os exemplares de cacaurana hemaramohi (Theobroma bicolor) são deixados nas roças, quando lá encontrados. Sua presença indica áreas propícias para roça, informação que me foi passada oralmente em duas regiões, nas serras e nas terras baixas. São mais indicativos de que há um grande conhecimento associado às escolhas de locais para roças, conforme já apontado em grande parte da literatura dedicada ao assunto (SMOLE, 1976; LIZOT, 1978; 1980; ALBERT, 1992; MILLIKEN; ALBERT, 1999). Mas há outras relações interespecíficas dos Yanomami com formações vegetais além das relacionadas à abertura de roças e são usadas para a escolha da moradia, possivelmente envolvendo relações com caça e com a importância simbólica das capoeiras antigas, uma vez depuradas da lembrança de seus mortos, ou ocupadas por grupos que não tenham vivenciado alguma lembrança de óbito. Demonstrarei no correr do trabalho, localidades de feição similar, onde a reocupação de uma clareira se dá adjacente à antiga roça 
ocupada, muito tempo depois, reforçando a ideia de retromigração. No próximo estudo, centraremos em algumas elaborações aplicadas à escolha de locais para roças, sua divisão de cultivares, em uma sociedade sanuma já a bastante tempo habitando a mesma região serrana.

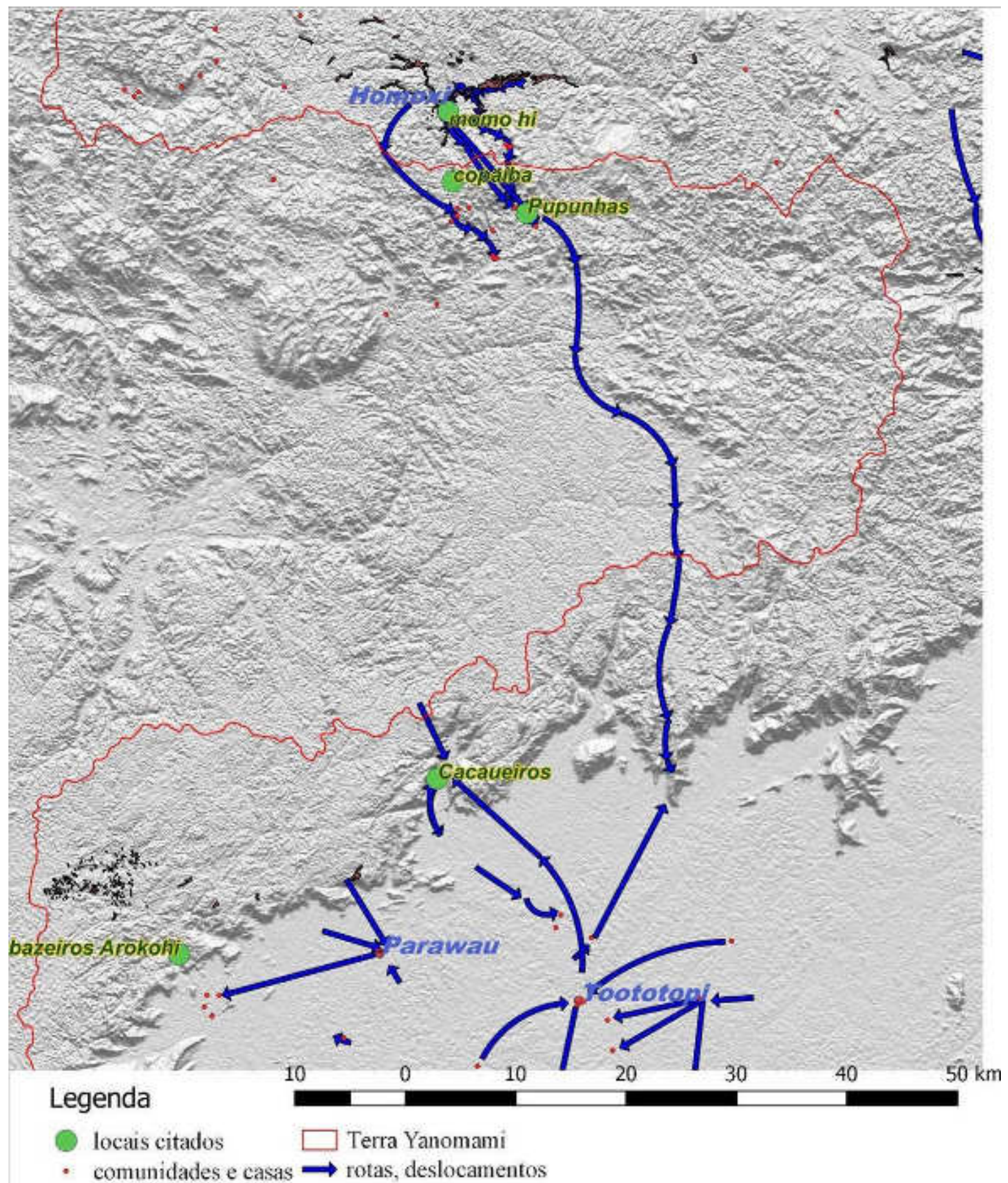

Figura 6: Mapa indicando a região com as ocorrências de árvores citadas no texto, desde o Homoxi, passando pelas cabeceiroas do Rio Orinoco, na Venezuela, e ao Toototopi e Parawau, nas terras Baixas do Amazonas Brasileiro.

\section{Awaris: Sobre fome, roças e aproveitamento territorial pelos Sanöma}

Muito se ouve, entre os sötönapö (não indígenas, não Yanomami, nem sanöma nem yekuana) que trabalham em área, pela assistência à saúde, de haver um mau aproveitamento 
territorial dos Sanöma, de suas técnicas de roça serem causadoras de fome. Alguns estudos já demonstraram, dentro do modo de vida Yanomami e Sanöma (SMOLE, 1976; LIZOT, 1978; 1980; COLCHESTER, 1982; ALBERT, 1985; 1992; MILLIKEN; ALBERT, 1999), que suas atividades econômicas são capazes de prover a proteína e os carbohidratos necessários para a sua existência. Considerando a hipótese de particularidades desse universo do Alto Rio Awaris: a) da configuração espacial de pequenas baixadas sedimentares em uma região de serras, com níveis de base da ordem dos $600 \mathrm{~m}$ de altitude, cercado por elevações rochosas maiores onde há menor biomassa e baixa disponibilidade de caça e peixes, b) a sedentarização dos Sanöma e Yekuana numa parte desses terrenos sedimentares forma uma crescente concentração populacional sem precedentes entre os Yanomami em região de serras, c) de uma interculturalidade entre os Carib Yekuana e os Sanöma yanomami, cujas diferenças em uma relação nem declaradamente belicosa nem completamente aliada geram rumores (RAMOS, 1979, 1984; JABUR, 2014); e d), de os Sanöma de Awaris se assentarem sobre terrenos já utilizados pelos Yekuana, num passado relativamente recente, poder-se-ia pensar um estudo mais detalhado sobre se essas condições são causadoras de subnutrição levando à morbidade.

Algumas pequenas pesquisas preliminares levaram a uma conclusão contrária a isso, mas numa abordagem geoespacial sem muita troca de informações com a comunidade: foi levantado o conteúdo em quantidades de espécies e de cultivares e avaliado, utilizando tecnologia GPS, a proporção no espaço de quatro roças destinadas à alimentação familiar. Foi levantada a quantidade de clareiras durante aquele mesmo período da visita (2001) para verificar se, em diversidade e em quantidade, a alimentação dessas famílias em particular, extrapolando para a região ${ }^{18}$.

A quantidade de roças não difere muito de outras partes da Terra Yanomami em serra (MILLIKEN; ALBERT, 1999) não podendo atribuir a isso diretamente o problema principal

18 Naquela época, conversando com o Mimica, (Edmilson, missionário da Meva) que convive a tempos com os Sanöma, ele informou que, a rigor não há um grande problema de subnutrição, apenas o modo de vida Sanöma, ou algum problema eventual de escassez ligado à sazonalidade climática, ou a algum problema familiar, velhos ou crianças demais numa dada distribuição familiar. Corrobora com isso o estudo de campo + sensoriamento remoto realizado. 
de fome e subnutrição. De fato, antes de julgar a situação crítica, cabe refletir com os Sanöma de Awaris com foco numa visão mais existencial dessa sociedade: uma vez colocadas novas condições de existência, novas necessidades também surgiram e trouxeram novas maneiras de os Sanöma enxergarem sua própria realidade, tendo de dar conta de explicar as alteridades até então desconhecidas (GUIMARÃES, 2005b; JABUR, 2014). Novos desejos e necessidades parecem explicar melhor as questões em curso para os Sanöma do que a condição objetiva da fome, escassez. Dentre as novas necessidades, o ambiente intercultural vem a criar a necessidade de defender seus cultivos ante a cobiça dos outros coabitantes da região. Embora sejam os Sanöma mesmo vítimas das desconfianças alheias, isso não os isenta de igualmente defender os produtos de seus trabalhos. A situação intercultural impõe incertezas sobre os vizinhos, pois as éticas de cada um se misturam; não há mais o controle social que poderia advir de uma pequena comunidade onde todos se conhecem; mesmo entre os sanöma, há diversos grupos que coabitam a região sem se considerarem como pertencentes de um mesmo grupo aliado (RAMOS, 1990).

Apresento aqui um estudo sobre a paisagem sobre a qual se desenvolve a sociedade Sanöma, e que a considera como seu locus de existência. Focarei principalmente na distribuição das roças. Os Sanöma são um subgrupo da sociedade Yanomami. Sendo os mais setentrionais dos grupos Yanomami, eles tiveram rápida expansão para o norte, na bacia do Rio Caura, Venezuela, onde mantiveram uma relação com os Yekuana, uma sociedade falante de língua Carib cohabitante dessas florestas, tanto no Brasil como na Venezuela, possuindo algumas peculiaridades em relação ao trato com o território: As roças Yekuana ocupam maior espaço e se ampliam com novas aberturas a partir da primeira clareira, já as roças sanöma são menores, ora de encosta, e podem começar novas roças em clareiras novas na floresta, ou seguir abrindo novas clareiras onde já começaram uma anterior. Os Yekuana realizam suas roças de mandioca em extensões muito maiores, pois processam seu produto em várias formas, do caxiri à farinha, sendo então toda ela colhida em uma empreitada; as roças sanöma atendem também a necessidades diárias, exceto quando da produção de beiju.

A roça Sanöma em Awaris possui maior parte sobre trechos já utilizados (hikalipata), geralmente pequenas e privilegiando as macaxeiras e mandiocas (nasisi), para obter provimento próximo, cotidiano, sem precisar caminhar para buscar nas mais distantes, produtivas e diversificadas. As clareiras identificadas em Awaris são contíguas em grande parte, chegando até as comunidades vizinhas, Mausia ao sul, e Katonau, ao norte; são 
provavelmente essas as observadas mais frequentemente pelos trabalhadores da saúde, influenciando-lhes o juízo acima relatado.

A sociedade Sanöma dessa região optou por residir próximo aos napö (Yekuana) e posteriormente os sötönapö (Não indígenas), que lhes conferiu um acesso maior aos utensílios industrializados. Não houve, com isso, alguma mudança de hábito em relação à floresta: nesse pouco tempo de estada, além dos produtos da roça, foi da floresta que vieram a maior variedade de produtos: os minhocoçu holemapö (ao que consta, aprendido com os Yekuana), coletados nos solos úmido próximo ao rio, lagartas torradas wakanani (idem), sapo soso, frutos como о lиерё, kерии (Inga sp.), as larvas de vespa kopina, diversos animais de caça, veado (hasa), mutum (paluli) enfim, uma infinidade de pequenos recursos, característicos da dieta Sanöma, compensando a pequena quantidade de pescado obtida, as piabas salaka pö que raramente ultrapassam dez centímetros...
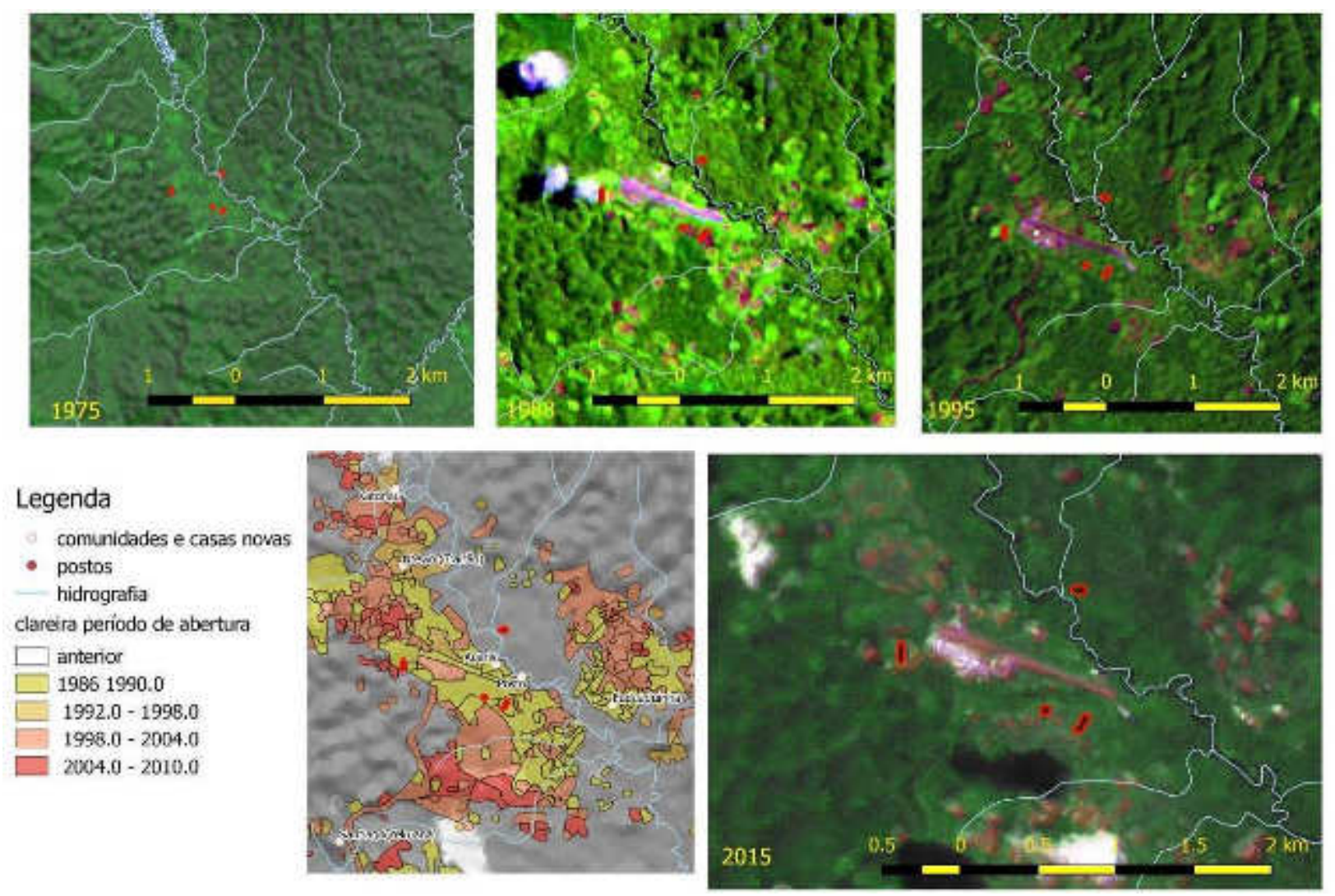

Figura 7 evolução histórica das clareiras a partir de 1975, cerca de dez anos de instalação missionária, a pista ainda de chão e os Yekuana na mesma margem do rio; imagem Landsat 1 MSS pixel de 80m. 1988, com a pista já construída e os Yekuana já em Fuduaduinha, do outro lado do rio; 1995 mostra menor desenvolvimento de roças, e a linha de transmissão para a usina hidrelétrica, construída com mão de obra indígena (ambas imagem Landsat TM5 resolução espacial de 30m.). Por fim imagem de 2015 Landsat 8 com 5m de resolução espacial, com a pista e as instalações em destaque. E o mapa resultante, com a abertura de clareiras conforme as épocas citadas.

A floresta é a fornecedora principal de recursos, os sanöma sendo detentores de particularidades em relação a outros povos amazônicos, como o uso de cogumelos (hasa 
amo), entre outros, retiradas principalmente das áreas em regeneração de antigas roças. A permanência por meio século ao lado dos missionários implicou numa menor disponibilidade de terrenos para as roças, que se ampliaram sobre onde já existiu uma comunidadade Yekuana, hoje habitante da outra margem do Rio Asikamatu (Awaris) e denominada Fuduaduinha. A Figura 7 apresenta uma sequência de mapas com a evolução de clareiras nessa região da Pista de Auaris, entre 1975 e 2015.

Os solos amazônicos, sobretudo os dessa região de serras são considerados pobres em fertilidade, mesmo a decomposição dos elementos da floresta, não permanecem integralmente no solo, por ser serra, são na maior parte das vezes carreados rio abaixo, os remansos alagáveis na estação da seca guardam mais areia e sedimentos grossos, os solos sedimentares que os Sanöma optaram por ocupar, observam-se poucos depósitos mais orgânicos. Num local onde a morfogênese e os processos sedimentares são maiores que a pedogênese, a sustentação da fertilidade agrícola se dá pela técnica de corte e queima, os Sanöma, à maneira de outros povos indígenas da Amazônia, queimam para incorporar a fertilidade da biomassa ao solo a um prazo curto, pois a um prazo mais longo - conforme assistimos agora - há um desgaste do solo só possível de ser corrigido com a recuperação florestal, e a regeneração se torna muito mais difícil quanto mais longe está o banco de sementes, o quanto maior for a clareira e mais tempo utilizado, num mosaico de roças abertas sob capoeiras de roças antigas sem florestas por perto. O entorno da pista é exemplar nisso, e se estende até comunidades seguintes, conforme afirmado acima. O estudo sobre as roças, de 2001/2002, vêm a demonstrar que as clareiras abertas não são excessivas no período, mas áreas alteradas, regenerações de roças antigas, são evidentes. A quantidade de pteridófita morumoruma siki (Pteridium acquilinum) indica a maior frequência com que esses trechos foram queimados. A área utilizada limita-se pelos solos aluviais mais planos, imprensados pelos conjuntos montanhosos da região, de solo essencialmente residual.

As áreas abertas utilizadas atualmente para plantio pelos Sanöma ou pelos Yekuana, obedecem a uma organização por família: Chileno, meu informante que aceitou esclarecer um pouco essa dinâmica de roças, possui uma roça próxima, com mandioca, para o dia a dia, outra distante, abastecendo a família com todas as outras variedades vegetais cultivadas, ainda uma outra em crescimento, que servirá para alimentação futura.

A roça distante, do outro lado do rio, tinha o objetivo de ficar mais escondida alheia a 
investidas de pessoas intencionadas em subtrair... Nela não havia Manihot, de nenhum cultivar, sendo toda dividida entre as outras espécies tradicionalmente cultivadas: milho, em grande quantidade, com alta densidade, três ou quatro variedades de inhames e taiobas, uma, inclusive com folha comestível, a dioscoreácea cará de árvores Dioscorea sp (kabölöma sikö), tabaco Nicotiana sp. (pini), milho Zea mays consumido como milho verde, grande variedade de bananeiras, plantadas misturadas entre si; foram enumeradas seis cultivares em menos de 100m²; abacaxi (sama), outras espécies comestíveis de ruderais e de regeneração, como a cucurbitácea sapo (da qual se utilizam as sementes), e a solanacea soka (semelhante a uma fruta de lobo, joá) Essa roça se encontra rio acima de sua casa, na outra margem, numa baixada sedimentar fluvial, provavelmente beneficiária das inundações sazonais do Asikamatu (Rio Awaris) que lhe fertilizam o solo.

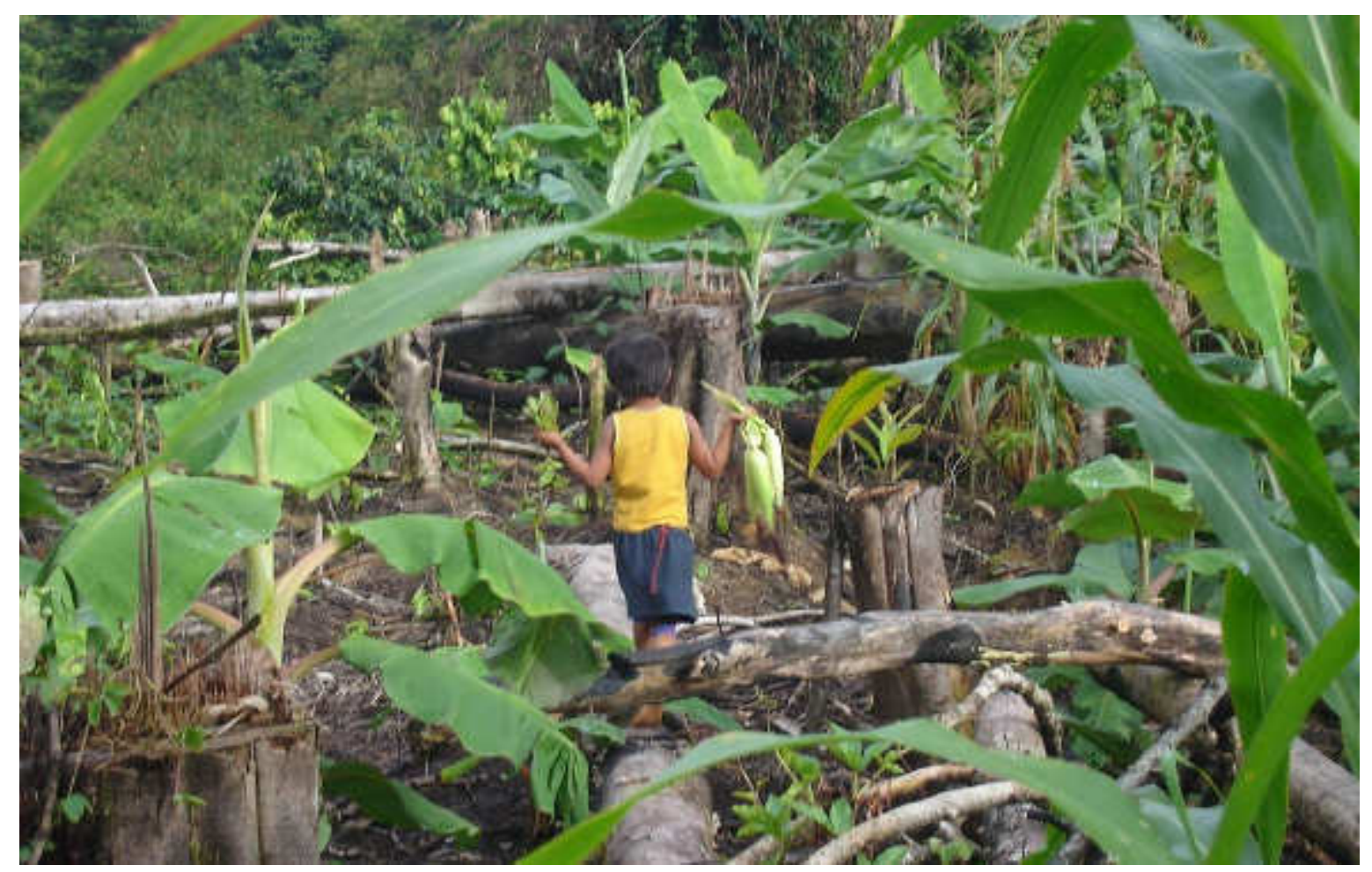

Figura 8 roça de Chileno, com seu fiho carregando milho sinomo, e tabaco pini, sobre um tronco caído. Vemos também cultivares de banana, associadas a outras plantas, imitando a diversidade da floresta.

As duas outras roças, nas adjacências da pista, têm algumas dificuldades de acesso, mas são mais vulneráveis a estranhos, portanto não há plantas mais nobres, como o abacaxi, cultivado em locais mais reservados. Segundo informações do dono, essa roça alimenta sua família, mais a família de sua irmã, com cinco filhos, e eventualmente ajuda a família de sua outra irmã, de seu pai etc. São extensas roças de mandioca, já na borda das terras planas sedimentares, ora alcançando o sopé da encosta de colinas próximas, onde, em geral os 
Sanöma evitam cultivar. A Tabela 1 apresenta uma distribuição esquemática dos cultivares encontrados nas roças estudadas.

Tabela 1: área e cultivares da roça familiar de Chileno.

\begin{tabular}{|l|l|l|}
\hline DESCRIÇÃ̃ & AREA & produtos principais \\
\hline Roça Chileno pista nasisi & 0.5902 & Mandioca macaxeira \\
\hline Roça Chileno Asikamatuu & 0.4807 & Banana, milho, tabaco, taioba, carás, abacaxi \\
\hline Roça Chileno mandioca & 0.3234 & Mandioca macaxeira nasisikö \\
\hline Roça Chileno mandioca & 0.6494 & Mandioca macaxeira nasisikö \\
\hline
\end{tabular}

Área expressa em hectares

As áreas aferidas totalizam um pouco mais de dois hectares, e tem sua conformação assim distribuída pelas razões acima descritas. Normalmente, esse conjunto supre as necessidades de carbohidratos dessas famílias, baseados no uso da Mandioca como alimento principal. A roça mais a oeste já alcança áreas cercadas de encostas, e todas as áreas na verdade se beneficiam de capoeiras oriundas da ocupação dos Yekuana desde a instalação dos missionários, em 1963 (JABUR, 2014), diverso do encontrado em outras regiões, onde se abrem áreas florestais com biomassa maior para cultivo de novas roças. Não parece haver disponibilidade dessas condições, depois de meio século de ocupação. A Figura 9 apresenta em mapa a localização das roças estudadas, perante a pista e a casa de Chilento, no centro da comunidade de Auaris.

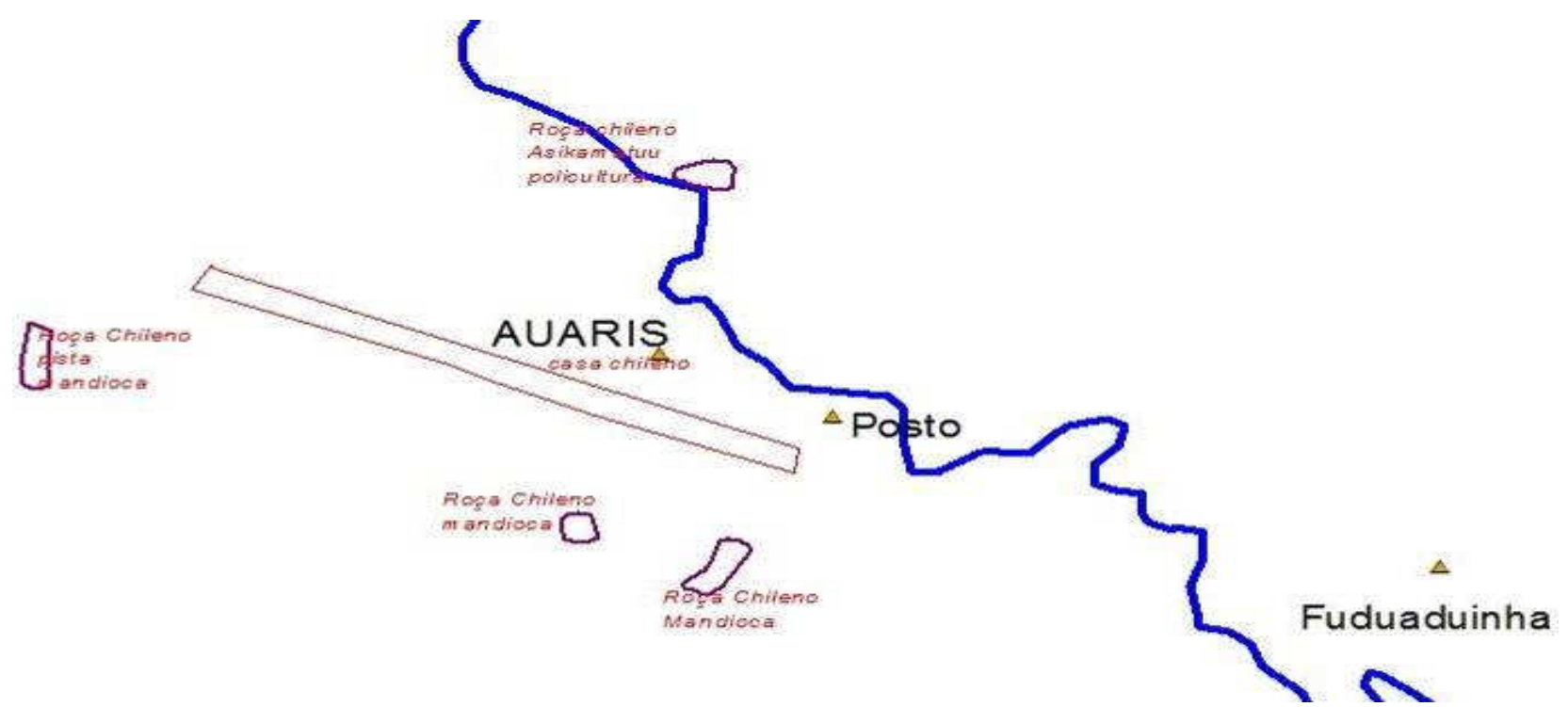

Figura 9: disposição das roças de Chileno no contexto da região de Auaris, pista de pouso e Rio Auaris (Asikamatu). A pista, com $1200 \mathrm{~m}$ de comprimento pode servir de escala.

O outro sobretrabalho implica na coleta e caça, ou seja, no uso da floresta de maneira geral. Embora um estudo desse tipo seja do maior interesse, ele não deve ser guiado pela idéia de fome, de subnutrição da população, mas de ter parâmetros sobre o suporte ambiental, cuja sobrecarga parece implicar em uma necessidade de aumento nas horas de trabalho da família. 
Avalio haver, em vez de escassez alimentar, uma demanda por produtos diferentes, que também implicam em busca de alternativas econômicas. Observei as estratégias de plantio de Chileno resolvem dois problemas ao mesmo tempo, um ecológico e geográfico, de obter alimentos próximos, ao mesmo tempo possuir plantios mais diversificados, e utilizando a mobilidade para aproveitamento da fertilidade impermanente; e outro social, de garantir certa privacidade sobre os produtos mais cobiçados.

A mandioca sendo a base alimentar dos Sanöma garante boa parte da alimentação, fazendo o papel exercido pela banana nas comunidades Yanomami das terras baixas. Sua importância é evidenciada pelos fornos para produção de farinha e sobretudo de beiju. A proximidade com os Yekuana, grande produtores de farinha, não deve ser negligenciada. Estudar a roça de uma família Sanöma parece apropriado em um local onde a definição de 'comunidade' não se atém à localização geográfica, e há maior importância do parentesco, diferente do encontrado em outras comunidades Yanomami; devemos levar isso em consideração quando tratamos de as roças estrategicamente serem mais inacessíveis.

Por fim, a discussão do processo histórico levando a uma ocupação por um tempo muito mais longo do usual nessa região, como atestam relatos da ocupação impermanente até a chegada da missão sugere mesmo haver um interesse existencial no contato, naquilo por ele proporcionado, acesso a serviços de saúde e outros bens materiais a facilitar a vida. Num contexto de sedentarização maior, parece inegável as mudanças das condições ambientais, levando a uma tolerância maior à reutilização de terrenos já anteriormente ocupados, pelo só fato de manter-se próximo dos sötönapö. Segundo depoimentos coletados por Clarisse Jabur, os Sanöma empreenderam um aumento do uso de fontes de alimentares oriundas da coleta, como os cogumelos e animais menores, cobras e anuros (JABUR 2014), pois a caça já vem escasseando desde muito (RAMOS, 1991), também aumentando a distância das caçadas coletivas. Não parece sensato tratar como consequente da limitação ambiental simples a opção dos Sanöma em permanecerem próximos à pista, quando se tem a mobilidade como mera resposta adaptativa. A opção de não ir, implica em outros rearranjos alimentares, e não deve ser entendido como sedentarismo, sendo que os Sanöma permanecem frequentando a floresta empreendendo longas caminhadas e parte deles optam por mudar para novas posições, saindo da concentração do entorno da pista, onde convivem várias comunidades, expressos pela existência de Sibs distintos (RAMOS, 1973; 1990) habitando a beira da pista, mas não se reconhecendo como uma única. Um caso recente de macromovimento, foi a ida da 
comunidade do Mausia refundando o Olomai, rio abaixo, em 2007-8 (NILSSON e FEARNSIDE 2011). Isso coloca como presente processos aqui descritos dentro do contexto da mobilidade e da construção da paisagem. Não define porém, a possibilidade de o posto e a pista de Auaris verem-se desocupados, pelo grau de atração ali implicado com a presença estrangeira sötönapö e seus desdobramentos.

\section{Considerações finais}

Nesse capítulo, apresentei exemplos das observações de campo e convivência com os Yanomami, extensivo aos Sanöma, de que há uma coexistência com a floresta em que os Yanomami aparecem como ativos construtores de características, vegetações, formações encontradas nas florestas amazônicas em que habitam. Esse processo deve ser compreendido não como um controle absoluto sobre as características do ecossistema, mas muito mais como uma coevolução em que, em certa medida, as modificações aqui reveladas são respeitosas às vocações desses ecossistemas habitados. Embora os yanomami tenham com a planta uma relação geralmente distinta com os animais, com os quais compartilham identidade através do rixia ainda conectados pela sua existência em versão animal, codependentes, com as plantas não se desconsidera sua agência, através dos xapiri (sapuli), entidades agentes cosmológicos da estabilidade do universo, e das relações nas mais variadas escalas.

Todos os exemplos aqui apresentados indicam que os distúrbios em escala intermediária produzidos pelos Yanomami tem uma temporalidade relativa, e resultam, em um ciclo maior de tempo em uma paisagem similar à 'original' (difícil admitir uma existência de original, uma vez que não há certeza se foram essas construídas sobre antigas ocupações indígenas, derivadas de outros processos similares de ocupação humana).

O papel dos Yanomami na paisagem florestal, embora tenha entre seus processos os distúrbios intermediários, não resulta em uma paisagem distoante da previsível pelas condições climáticas, físicas e pedológicas do bioma amazônico, mas sugerem mesmo um caminho comum: uma paisagem florestal com diversos elementos significativos para a presença humana.

Além da ecologia histórica, em seu mérito de visibilizar o papel das humanidades ameríndias na transformação do lugar em que vivem, proponho uma composição com Ingold (2010) e a ideia de meshwork, cuja imagem imerge a própria humanidade na teia de relações 
holográficas constituintes do sistema todo, e incluso o sistema xamânico xapirimuwi e seus seres entidades xapiripë (KOPENAWA e ALBERT 2015). Há mais de um xapiri para cada espécie significante aos yanomami, a coexistência dessas espécies tem seu representante na negociação cosmológica dos xapiripë, dando uma dimensão do quão complexo as coexistências vegetais com os yanomami são significadas no processo de promover o concerto do mundo.

A grande diversidade de elementos utilizados pelos Yanomami têm fundamento na própria diversidade inerente à floresta, e é de se imaginar que boa parte desse aproveitamento nasce de uma arguta observação, comunicada eficazmente entre os membros da sociedade. As práticas relacionadas à mobilidade tornam-se essenciais para tais efeitos prosperarem, em processos coevolutivos, onde os Yanomami compreendam a floresta como agente em constante interação. As decisões de permanecer ou criarem novas moradias nascem desse diálogo especulativo, em que saberes são construídos num treino constante de observação do meio vivido, numa percepção em que é difícil separar o que não é 'humano' (Yanomami) e o que não é 'floresta' (urihi). O recente trabalho de Reig (2013) aponta em direção semelhante, sua tese dialoga com vários autores que trataram do tema. Embora as observações aqui apresentadas não se proponham a ser conclusivas, muito mais ilustrativas, são elementos para reflexão na direção de se construir uma ecologia histórica Yanomami, sem olvidar as estratégias políticas dos Yanomami concernentes à relação intercultural cada vez mais presente e marcante que as sociedades, os Estados Nacionais impõem dos dois lados da fronteira. As relações sociais envolvidas nessa ecologia histórica apresenta a característica de não se filiar a um poder central, tendo muito mais a dissidência como estratégia de nega-lo, e as alianças intercomunitárias o modo de constituir a rede de relações que tramam a malha de trilhas pela floresta. 


\section{Posto de contato, vacina etnográfica?}

A experiência em educação para a saúde da Urihi (floresta) Saúde Yanomami:

\section{Introdução}

O posto de contato pode ser visto como um ponto metafórico e minimal do encontro intercultural das sociedades de Estado com os Yanomami; ao mesmo tempo é o resultado de um aprendizado das sociedades de Estado sobre o risco epidemiológico do contato, numa tentativa de torna-lo menos nefasto aos povos no interior do território nacional. Independente de concordância com o postulado enunciado acima, torna-se um interessante locus de análise de relações interculturais distintas das encontradas na cidade ou sob a ótica exploratória convencional.

As populações ameríndias estão sujeitas aos riscos de um choque epidemiológico, devido ao contato com agentes etiológicos aos quais ainda não possuem defesas (RIBEIRO 1956). Isso impõe a necessidade de levar assistência à saúde aos povos indígenas recém contatados, em muitos casos ampliada pela piora das condições sanitárias, ocasionadas pelas pressões sobre suas terras. As epidemias xawara assolaram os Yanomami ainda antes do contato, provocando temor de perdas populacionais. Há relatos de casos em que mesmo sem conhecer os não-yanomami napëpë, eram acometidos de doenças que afetavam uma parte da população.

As incompreensões entre as abordagens e visões cosmológicas de saúde, doença e morte entre os sujeitos envolvidos, e a necessária tradução amplia o caráter desafiante dessa tarefa. Há exemplos de resistência ao tratamento médico pela incompreensão de seus termos, também de recusa à convivência das práticas terapêuticas do sistema médico com a xamânica por motivos higienistas, sanitários entre outros (SILVEIRA, 2004). Mas há também coincidências de abordagens nos modos de agir e pensar e, mesmo sem convergirem plenamente, permitem diálogo e colaboração no tratamento, semelhante a um 'equívoco controlado’ (VIVEIROS DE CASTRO, 2004), ou um ‘equívoco produtivo’ (KELLY, 2009).

Viveiros de Castro (2004) trata das abordagens xamânicas, de entendimento de naturezas diferentes: no processo de abordar o outro mundo, o xamã mergulha nele para 
conhece-lo, praticando o "método da equivocação controlada", conforme ele denomina. O pensamento indígena não se molda ao nosso pelo simples traduzir de palavras, representando visões de naturezas e culturas distintas da nossa; Kelly (2009) sugere ser similar à atitude dos Yanomami frente ao nosso sistema lógico. Diante dessa impossibilidade de tradução plena, há uma admissão da intencionalidade, permitindo a ação colaborativa, isso correponderia a uma transposição cosmológica da equivocação controlada.

Um processo lógico similar de tradução se aplica quando observamos modos de vida distintos, quando tais diferenças se refletem nas territorialidades, constituindo um outro aspecto do desafio da assistência à saúde a povos indígenas recém contactados: as distâncias e os modos de ocupar a terra/floresta, traduzindo-se em ampla mobilidade, impõem nova dificuldade em localizar/acompanhar os povos e pessoas a serem tratados, em suas movimentações.

Os Yanomami enfrentam as situações de contato num misto de interesse e medo, conscientes das epidemias que podem lhes assolar. Houve diversas frentes de contato históricas, mas boa parte da população pode ser caracterizada como de recente contato. Considerando as experiências impactantes com a construção da Rodovia Perimetral Norte (década de 1970) e a primeira grande invasão garimpeira, entre 1986 e 1998, os postos de contato e a assistência à saúde passam a ser uma necessidade, para evitar uma catástrofe epidemiológica.

A organização de um sistema de assistência à saúde indígena é um processo recente. Em 1992 foi criado o Distrito Sanitário Indígena Yanomami (DSY), com objetivo de transformar a ação em saúde indígena de uma situação emergencial para uma estrutura institucional ${ }^{19}$. A partir de 1999, a Lei Sergio Arouca (9.836/99) permitiu às organizações não-governamentais participarem da administração do sistema de saúde. Isso garantiu o funcionamento do sistema, com a redução significativa dos níveis de malária e outras causas de morbidade na Terra Indígena Yanomami (TIY) (PITHAN 2005).

Os Yanomami têm no posto uma referência, uma atração pelos recursos ali ofertados, em termos de ferramentas, utensílios e serviços de saúde. Essa atração sempre foi

19 Funasa Fundação Nacional de Saúde. Projeto Saúde Yanomami Ministério da Saúde; 1991; 32 p. 
acompanhada simultaneamente de um grande receio, de saber serem aqueles estrangeiros os transmissores de enfermidades e potenciais causadores da morte. Gravitando entre essas duas potencialidades, os Yanomami se arriscam ao contato com o posto fixo, na busca de utensílios raros, especialmente ferramentas de metal. Notemos, de antemão, que a cobiça por essas ferramentas advém de sua utilidade dentro do habitar a floresta pelos Yanomami, por facilitar a mediação e o trabalho com a floresta, aprofundando essa experiência em vez de nega-la.

\section{Vacina etnográfica}

O Antropólogo Bruce Albert em sua tese (1985) escreveu ser o posto avançado de contato uma espécie de vacina etnográfica: ao oferecer "doses homeopáticas atenuadas" de nossa sociedade, permite aos Yanomami um primeiro exercício de antropologia reversa (Wagner 1981), exposto ao contato de partes minoritárias dessa sociedade de Estado. Os funcionários da saúde são minimamente preparados para o convívio com um povo de recente contato, sem no entanto abandonarem idéias preconcebidas sobre os povos indígenas, ora concebidos como 'primitivos, pobres, miseráveis'. Essa carga de preconceito reforça aos Yanomami perceberem aquela alteridade (ainda de forma 'amistosa') como um napë, um outro, um "contra", uma mistura de inimigo detentor de utensílios desejados e de necessários saberes biomédicos proporcionando cura e a prevenção de doença. Leiamos o escrito na Tese de Bruce Albert em 1985:

Os postos de organizações missionárias estrangeiras e da administração indigenista nacional que são interpostos entre os Yanomami e a frente pioneira durante os anos 1950 a 1970, tiveram uma influência em múltiplos níveis sobre os índios. Este impacto, se está longe de ser desprezível, permanece todavia, ao menos no Brasil, sob um mal menor e se trata de uma forma de contato atenuado. Nós estamos aqui lidando com um contato com os representantes locais de organismos adeptos a ideologias assistencialistas (crsitianismo missionário, filosofia 'comtiana' da Funai) que constitui inegavelmente a versão menos nociva do mundo "branco" na sua expressão regional sob essas latitudes.

Missões e postos indígenas tem sido, no contexto específico que nós descrevemos, como um tipo de "vacina de contato" em fornecer aos Yanomam uma experiência da sociedade nacional menos mortal e etnocida que aquelas que eles haveriam de afrontar se estivessem travados confrontados duramente às formas de violência e exploração brutal impostas por uma frente pioneira regional limitrofe unicamente guiada por seus apetites econômicos desenfreados.

Esta experiência de um "contato atenuado" deu assim a oportunidade a um certo número de comunidades de fazer (antes de serem dizimadas ou desmanteladas) uma aprendizagem do "mundo branco" que lhe é indispensável para sobreviver e lutar eficazmente contra o avanço agressivo e inelutável de uma sociedade regional marcada pela paixão pelas riquezas minerais de seu território.

Assim não é por acaso se os representantes Yanomami aos encontros regionais ou 
nacionais dos movimentos indígenas que começam a estender ao Brasil são oriundos em sua maioria de comunidades situados à proximidade de missões ou de postos da Funai.

A questão sanitária fornece um exemplo particularmente eloquente - e literal - do papel ambivalente de "vacina de contato" tido por esses estabelecimentos permanentes, missionários ou governamentais, em território Yanomami.

A assistência paramédica fornecida pelas missões e de uma forma menor pelos postos da Funai criou por exemplo uma situação de dependência extrema para os Yanomami que, sem ela, se vêem condenados a uma dizimação certa. Dependência que não seja, ao menos indiretamente, utilizada como uma forma de poder estabalecer a empresa de assimilação que constitui a racionalidade dos postos avançados da civilização.

Esta assistência uma vez baseada sobre os critérios médicos aproximativos, tende igualmente a em demasiada frequência a incitar ao sobreconsumo de medicamentos (nem um pouco apropriados, hoje), e então não somente a incrementar a dependência e a produzir efeitos perversos sobre o plano médico, mas também a desprezar todo uso de uma farmacopéia tradicional que, em certos casos ao menos, pode se mostrar mais adequado.

Malgrado esses pontos negativos que, se eles não são desprezíveis, podem ser em parte corrigíveis por um esforço de formação (que essas missões e postos são de qualquer maneira largamente demandados), esse tipo de assistência paramédica tornou possível não somente a sobrevida mas também um forte crescimento demográfico dos grupos que se puseram a se beneficiar. (ALBERT, 1985: 88-89 tradução livre minha)

A ideia de vacina etnográfica proporcionada pelo posto de saúde nos permite refletir sobre a capacidade dos Yanomami de responderem ao desafio desse diálogo com o sistema biomédico, etnograficamente se apropriando do que lhes é útil, a atenção à saúde, e se defendendo de suas práticas coloniais associadas ao biopoder e à higienização, paradoxalmente. Coloco aqui a questão desse capítulo: até então o contato com sociedades de Estado tem sido interpretado como algo inexoravelmente transformador dos modos de vida das sociedades ameríndias, porém, vários trabalhos tem demonstrado sua capacidade de resistir; a idéia de uma vacina etnográfica parece possibilitar um conhecimento do outro que lhes permita alguma defesa.

Vou buscar junto aos Yanomami as competências apreendidas, por um lado, e as percepções das atitudes dos poucos napëpë (não-yanomami) com quem convivem no posto, enquanto representantes da sociedade de Estado; enquanto pessoas criadas e escolarizadas segundo um dado modo de pensar, essas reproduzem o pensamento hegemônico de sua sociedade, salvo ter feito a devida crítica e admitir ser artífice dos Yanomami em sua luta por simetrização das relações; afirmo assim que, na sua antropologia reversa, os Yanomami descobrem e se aliam com esses potenciais tradutores. 
Nesse processo, esse trabalho evidencia a importância da aquisição de competências em operar com ferramentas, conceituais ou não, da alteridade. Em grande parte a habilidade de compreender tais conhecimentos advém, menos da sintonia de modos de compreensão e mais da ação prática de operar as ferramentas; e tal habilidade se faz por um empréstimo de atividades desenvolvidas na floresta, em seu experienciar cotidiano. Apresento atitudes, gestos e percepções desse processo pelos yanomami, além das reflexões e discursos que norteiam suas atitudes, como pensam as relações interculturais, enquanto ainda são a sociedade predominante na floresta, testando a hipótese do posto de contato como vacina etnográfica. Defendo então que esses dois aspectos das descobertas sobre o outro, sua técnica, por um lado e seu modo de pensar, revelado nas pequenas atitudes, como que uma representação fractal da sociedade de que é expoente, são necessários para compor essa primeira imagem de resistência transformadora, de ao mesmo tempo permanecer sendo, e apropriar-se de saberes exógenos, reinventando-se.

\section{A Urihi - Saúde Yanomami}

Urihi significa 'floresta' e também 'terra', em Yanomami (ALBERT 1992), e foi a denominação escolhida para a organização que prestou assistência a saúde de $63 \%$ da população da TIY de 2000 a 2003. Antes, essa mesma equipe havia realizado um programa de saúde em algumas regiões da TIY, através da Comissão Pela Criação do Parque Yanomami (CCPY). O desafio da Urihi implicava em organizar o sistema de saúde partindo de uma situação de forte epidemia: foram notificados em 1998 um total de 3.968 casos de malária. Ao final de 2000 a redução é sensível. No primeiro semestre de 2003 o total foi de 12 casos. A queda na incidência de malária, resultante da assistência da URIHI, é de $99 \%$. A mortalidade infantil foi reduzida em cerca de $65 \%$ e a redução do número de casos de tuberculose em relação à década passada é de $60 \%$. Desde 2001 não ocorreu uma só morte por malária entre os Yanomami sob responsabilidade sanitária da URIHI (dados da organização) ${ }^{20}$.

A postura de oferecer tratamento, sem imposição, contrasta com uma série de conflitos envolvendo interdições ao xamanismo (xaporimou), tratamentos não bem esclarecidos e que entravam em choque com os modos de abordagem de corpo e doença para os Yanomami, impedindo uma sinergia do processo de cura. Sinergia almejada e às vezes conquistada graças

20 Disponível em: http://www.proyanomami.org.br/v0904/index.asp?pag=noticia\&id=2542 acessado em 22 de outubro de 2017 
às coincidências que, independente de originados de diferentes modos de pensar permitiram colaboração no processo de cura. A simetrização das relações permite que ambos busquem novas abordagens teóricas para dar conta dos fenômenos proporcionados pelo contato intercultural. Os yanomami reconhecem assim, uma diferença entre suas afecções clássicas, definidas pelos seus modos de explicar a doença, das "doenças de branco" que às vezes atacam coletivamente na forma de epidemias "xawara". Na etiologia experimentada pelos Yanomami, a Xawara está relacionada à liberação de substâncias do subsolo, minérios e outras invisíveis. A abordagem reflete a capacidade do pensamento ameríndio de repensar o seu momento histórico vivido, produzindo novos conceitos sobre tais doenças. Nessas abordagens, o meio, as condições sanitárias assumem um papel na explicação da doença. As práticas de alteração do ambiente adotadas pelos não Yanomami, sobretudo a emissão de fumaças são elementos etiológicos provocadores das novas doenças (ALBERT, 2002). Embora não corresponda ao modo como concebemos a epidemiologia, a abordagem identifica o fenômeno sanitário como uma questão igualmente ambiental para identificar a etiologia da epidemia xawara.

Com a assistência permanente há maior presença em área de profissionais de saúde, nos postos e nas comunidades, inibindo a presença de garimpeiros. Após o término desse convênio em 2004, a presença de garimpeiros voltou a aumentar, contribuindo para piora da questão sanitária (DO PATEO, 2006).

O abismo conceitual existente entre os dois mundos não impede a cooperação no processo de melhora sanitária que combateu a malária com base num acordo com os Yanomami, assumindo eles o papel preponderante da busca ativa. Enquanto o aspecto pedagógico pensado pela Urihi, junto aos seus profissionais mais comprometidos, de que a autonomia dos yanomami achava aí um caminho possível, e o treinamento de microscopistas obteve êxito no combate à malária, junto aos profissionais de saúde: a época desse testemunho foi em 2000, ano em que entrei para a organização e expusemos a evolução mensal da malária em mapas, da área assistida pela Urihi.

O acordo em torno da atenção à saúde, numa situação de epidemia transcende a intenção e conta com a participação da comunidade; ao assumir importância "pedagógica" perante o fazer da saúde, focando nos Yanomami microscopistas, a organização de saúde abre espaço para uma aliança maior com os Yanomami, transformados e em "agentes de saúde/ 
microscopista"; pelo lado Yanomami, denominavam esse ato de pagar por serviços do microscopista de hiimapouwi: hiima é o animal de estimação, -pou é pegar, ter, sendo hiimapouwi o ato de fazer alguém de 'animal doméstico' esse mesmo termo vi usar para vínculos empregatícios. Tal condição estabelecia um vínculo com toda a comunidade, sobretudo com a família do microscopista escolhido; não eram poucos os mal-entendidos advindos da simultaneidade de dois sistemas: era comum ouvir falar de alguns comunitários cobrarem do microscopista Yanomami para permitir lhe furar o dedo, trazendo as relações 'comerciais' dele, para dentro das relações comunitárias, como um modo de distribuição de ganhos. Vamos comentar a habilidade dos yanomami de procurar formas de gameta, $\mathrm{o}$ plasmodium, observando sangue no microscópio. Quero especular um vínculo com habilidades desenvolvidas na experienciação da floresta. Identificar pequenas formas num campo de microscópio não era a questão mais complicada. complicado era confrontar teoricamente modos e concepção das coisas, das partes do corpo e concepções de doença...

\section{Microscopistas Yanomami no Parawau}

O Parawau foi um pólo de saúde aberto por obra do padrasto de Kopenawa, que aproximou-se politicamente de grupos a oeste do Toototopi, onde morava (PEREIRA, 2008); esses grupos falavam um dialeto distinto da língua yanomami, o Yanomamö, ou Yanomami, conhecidos como xamatari. Os xamatari admitiram habitar uma região do Roahikatiopëu, a cerca de seis horas de caminhada do Posto (ex missão) Toototopi. Os Wanapi $u$, grupo do padrasto de Davi Kopenawa, estão divididos em dois grupos, um no meio caminho do Toototopi e outro no Posto Yano, o posto em forma de casa circular yanomami, erguido do chão, servindo de base e moradia para as ações de saúde na região, à época, ainda executadas pela Comissão Pró Yanomami (CCPY). Luis Fernando Pereira (2008) relata a relação política entre os diversos grupos que o habitaram. No Parawau iniciou-se a formação de microscopistas, com a contratação de um paramédico ${ }^{21}$ para desenvolver formação:

Notícias CCPY Urgente, Data: 30 - Março - 2000

Titulo: Treinamento de microscopistas Yanomami da URIHI em nova fase

Fonte: Boletim URIHI - Saúde Yanomami, $n^{\circ} 1$

Cameron Macauley*

O programa de treinamento de microscopistas da URIHI na Área Yanomami ampliou-se (...) de modo a incluir três postos de saúde e quatro professores. Espera-se treinar 11 microscopistas durante o ano 2000, além dos cinco já formados até agora, três pela URIHI e dois pelo antigo programa de saúde da CCPY. (...) Um (...) curso já está em andamento em Balawaú.

21 ver http://www.proyanomami.org.br/v0904/index.asp?pag=noticia\&id=545; acesso em 20/04/2017 
O programa teve início em março de 1997, com o treinamento de três estudantes em Boa Vista, os quais passaram 30 dias aprendendo a diagnosticar a malária através do exame em microscópio de lâminas com esfregaços de sangue corado. Desde então, os três já foram aprovados em exame para obtenção do certificado da Fundação Nacional de Saúde (Funasa). O programa constitui uma experiência sem precedentes, já que esta é a primeira vez que pessoas da etnia yanomami, no Brasil, recebem instrução formal no setor da saúde.

Em novembro de 1998, o programa de treinamento foi reiniciado no posto de saúde de Balawaú, sob a direção do técnico Cameron Macauley, instrutor de microscopia. Durante 1999, dois outros estudantes concluíram seu treinamento e obtiveram o certificado da Funasa. Os estudantes também colaboraram com o antropólogo francês Bruce Albert na elaboração do Manual de Treinamento do Microscopista Yanomami, em português e no dialeto yanomae. O manual está sendo agora traduzido para o dialeto xamatari pelo jornalista e antropólogo Moisés Ramalho. (...)

Compromisso profissional

Depois de aprovados no exame, os estudantes comprometem-se a trabalhar durante três meses sob a supervisão de um microscopista com experiência, antes de concluírem o seu treinamento. A maioria dos microscopistas yanomami provavelmente irá trabalhar em suas comunidades de origem. Alguns, entretanto, terão que se deslocar para trabalhar em outros postos da Área Indígena Yanomami. Espera-se que os microscopistas yanomami ajudem a reduzir a incidência da malária, sem dúvida o mais grave problema de saúde da região amazônica. Além disso, desempenharão importante papel na formação de outros yanomami no diagnóstico e tratamento da malária, bem como vigilantes de saúde capazes de alertar outros profissionais baseados nos postos de saúde para a ocorrência de emergências.

* Cameron Macauley é instrutor de microscopia (2000)

Eu não participei nesse processo no Parawau citado pela notícia, a formação do microscopista Hugo, treinado por um membro da equipe, conseguiu ser aprovado no exame da Funasa/MS. Ao mesmo tempo, a equipe citada na reportagem não conseguiu aprovação de mais nenhum outro representante.

Durante o curso, também me foi relatado por profissionais de saúde presentes à época, o instrutor afirmou sobre o corpo humano ser comandado pelo cérebro, e recebeu o retruco de que o fígado o era, na concepção dos Yanomami. A compreensão do corpo humano revela-se aí uma dificuldade teórica real, tentar harmonizar formas de pensar diferentes na própria constituição do sujeito, do corpo e da vida. Mais do que um entendimento teórico, a ação prática de adquirir competência no uso do microscópio pode ser mais eficaz, considerando o contexto da necessidade de detectar a malária que eles vivenciavam como epidemia, denominada em Yanomami de hura a (em Yanomami: baço), pois a esplenomegalia, ampliação do baço, é um dos sintomas visíveis dessa doença.

Sobre o fígado ter proeminência no comando do corpo, não devemos subestimar o conhecimento implicado pelos Yanomami, pois ele encontra ressonância em resultados científicos que tem oferecido alternativas ao modo de pensar a doença: um aspecto é que a 
maior parte das drogas psicoativas depositam-se no fígado, e também as recentes descobertas das relações entre o nosso abdomen (sobretudo o intestino) e o cérebro. Há número similar de ligações nervosas no intestino e no cérebro e ambos interligados, conformando-se como extremidades de um sistema (PÓVOA, 2002). Convém supor uma simetria de importância, uma dificuldade teórica em separa-la, enquanto comandantes e comandados (para não dizer partes de um mesmo sistema).

A compreensão do corpo e sua abordagem política e divisão são diferentes em sua origem: embora os dois tenham palavras para identificar braço, perna, cabeça, o modo como os designamos pode ocultar um mal-entendido: há uma diferença de significado em cada língua, que enseja um modo de se relacionar com as 'partes do corpo': enquanto os Yanomami irão dizer 'ya poko' (eu-braço) nossa língua se refere a 'meu braço', sendo a forma utilizada pelos Yanomami impossível. Assim como impossível é a tradução literal de nossa expressão: "ipa poko" ("meu braço") não faz sentido em Yanomami e causaria repreensões alguém pronunciá-lo. Aplica-se "ipa" como "meu” quando se trata de um objeto, trocável ou não; não poderia ser uma parte do corpo que não é nem um utensílio e nem algo externo ao ser (do ponto de vista dos Yanomami) não pode ser trocado.

Todo um modelo de entendimento do corpo, quando postos em comparação podem gerar incompreensão mútua e estranhamento, embora ambos possam inadvertidamente conversar sobre os seus corpos, sem que essa diferença apareça. Mas as implicações de significação são evidentes: enquanto no nosso modo de falar, as partes do corpo se igualam ao mesmo tratamento que damos às mercadorias e utensílios e mesmo à terra, no caso do modo dos Yanomami falarem, as partes do corpo são de fato a pessoa, no sentido do pronome que a representa e a ela se refere. Mas não só: além do corpo físico há sua imagem essencial (utupë) seu alter-ego animal (rixi a), um interior (pei uиxi), e seu sopro (wixia), seu interior miami enquanto componentes da pessoa (ALBERT; GOMEZ, 1997).

Ao se buscar ensinar tendo como parâmetro o modelo biomédico, passa-se pelo modo de entender o corpo, pelo modo de entender a doença. A essa época, havia sido recém lançado o Manual etnográfico de saúde Yanomami, com enunciados úteis em várias áreas da prática biomédica, o que facilitou de sobremaneira os profissionais que a utilizavam. E ali estava clara a idéia de que o profissional oferece tratamento, em vez de impor. 
Colocar em choque os dois modelos, biomédico e o indígena pode ser uma das atitudes mais contraprodutivas no trabalho intercultural de saúde. O trabalho costuma ser uma prospecção mútua de diplomacias e de entendimentos que rendam significados para os dois. E a ação de cura prossiga, e a ação pedagógica mantenha-se recíproca nos aprendizados mútuos; esse seria uma tentativa de conciliar, modelo biomédico e xamanismo xaporimou, num pragmatismo contra epidemias xawara.

A aprovação de Hugo demonstra a importância de se pensar o método de ensino, tendo como base a habilidade: o treino em uma determinada área pressupõe que se desenvolvam habilidades relacionadas à compreensão do como fazer, para se entender conceitualmente o problema. Hugo foi igualmente o revisor yanomami do manual de malária. $\mathrm{O}$ desenvolvimento da percepção nos Yanomami tem um acurado conjunto de destrezas auditivas, visuais, perceptiva de maneira geral; com relação à visão, o treino de atenção e a acuidade visual desenvolvida permite que se enxergue um pequeno animal, um macaco ou uma ave no alto de uma árvore de 50m de altura, num emaranhado de folhas, galhos. Essa habilidade pode ser perfeitamente transposta para novos desafios, conforme afirmado acima: uma vez treinados ao uso do microscópio, sua regulação de foco e ampliação, detectar as formas de gameta num campo de uma lâmina, torna-se uma competência para os jovens microscopistas.

Os Yanomami admitem o tratamento da malária, de outras doenças, reconhecem a eficácia dos 'caroços' curadores dos napëpë, e ouvem atentamente as explicações etiológicas das doenças e parecem aceitar bem nossas preleções sobre microorganismos, invasões de nosso organismo (RAMALHO, 2008). Disso, parece ser admissível que as explicações empíricas ocidentais e a etiologia segundo a metafísica Yanomami seguem caminhos paralelos e não excludentes. Não parece haver uma refutação lógica de um sobre o outro, como se fosse obrigatório uma causa só, imersa numa única dimensão. A tolerância sobre uma realidade paralela e convivente garante aos Yanomami a lógica já detectada por Kelly (2016), em que é possível "tornar-se branco" sem deixar de ser Yanomami. A compreensão do modo de explicação da doença pela biomedicina não abala a metafísica Yanomami e sua etiologia de hekurapë, xapiripë, na forma de miniaturas humanoides de entidades sobrenaturais. Da mesma forma o tratamento biomédico não torna facultativo o xapirimou, o xamanismo capaz de curar segundo as lógicas dos Yanomami. Ele permanece uma necessidade se são identificados agentes etiológicos ligados aos xapirí. 


\section{Micropolíticas cotidianas do posto}

O exercício intercultural dessas competências para os yanomami contribui ao processo de conhecimento do outro também. Mas há uma compreensão do outro que não passa pela conquista de competências técnicas e operacionais: são aprendidas através das leituras corporais, dos lidares banais e cotidianos que se operam na convivência do posto: a vivência das práticas do outro, naquele espaço que é um enclave do estrangeiro "que precisa ser respeitado" e onde se vive conforme as regras de higiene e os protocolos do outro.

Os conflitos e a aprendizagem etnográfica com a postura dos missionários e o resultado do proselitismo religioso por eles tentado, é relatado por Davi Kopenawa em a Queda do Céu (2015: p.255-281). Ele conta, enquanto ainda era criança até a juventude, seu padrasto identificar nos missionários atitudes pouco civilizadas para os Yanomami, chegando a tornar motivo de briga, devido às incoerências da equipe e das posturas autoritárias frente ao xamanismo e os objetivos de evangelização. A postura do profissional no posto assume uma matiz diferente da retratada por Davi, mas não menos carregada de dificuldades de relação, quanto à imagem que os napëpë fazem dos Yanomami e também quanto às suas posturas quanto às coisas materiais.

Dentre as questões envolvendo apego aos elementos materiais, destaca-se o apego ao posto pelos servidores. São seu pequeno espaço, o pouco que lhe resta familiar em relação com a sede do Estado, Boa Vista, onde vivem, em sua maioria. Ali está o rádio, os equipamentos, a farmácia agregada e a despensa. Diferentemente de quem tem o alimento sempre trazido nos voos regulares quinzenais, em geral, os Yanomami tem na terra a referência principal em alimentação. Sempre há uma curiosidade etnográfica pelo alimento alienígena. Os Yanomami procederam a uma reinvenção dos nomes, macarrão chama-se horemapë, traduziria por vermes, minhocas, dada sua similaridade física. Arroz recebeu uma classificação '-xipë' enquanto o feijão recebeu '-mopë', de grão (-moku). Boi foi categorizado similar à carne de caça, claro, boi yãhi; mas lingüiça os yanomami criaram pela semelhança anatômica boi-moxi (pênis de boi). Tão logo os fardos chegam, são descarregados do avião e levados ao posto, como mantimento para a equipe de trabalho; a aparente grande quantidade de alimentos, contrasta com nossa mentalidade regida pela possibilidade da escassez. Somos levados, em nosso modo de pensar a economia, a premeditar a mínima possibilidade da falta, de os mantimentos poderem ser insuficientes. 
Mas a aceitação do alimento alienígena não é imediato: testemunhei diversas situações onde, ao serem apresentados a alimentos novos (por mim, muitas vezes) olhavam com desconfiança recusavam-se a comer e a mim, lançavam um olhar como se desconfiassem da minha humanidade; isso me remete às reflexões recentes na antropologia de Viveiros de Castro e seu perspectivismo ameríndio, também de Jose Kelly no que esse Autor se propõe a utilizar de Roy Wagner a homonímia em vez da sinonímia: para Wagner (1981) há uma torção naquilo que denominamos cultura, pois é exatamente o que é tratado pelas sociedades ameríndias como o inato, dado, mais afeito ao que chamamos de 'natureza'; a desconfiança é similar à que se apresenta em mitos: num deles, um aliado afim é convidado a colher pupunhas raxa kiki (Bactris gasipaes, uma palmeira domesticada e cultivada na roça) na roça, mas ao chegar depara-se com um pé de tucumã (palmeira selvagem, de frutos também comestíveis). O estranhamento marca a diferença do que ele chama pupunha, e põe desconfiança sobre a humanidade de quem trata a tucumã como se fosse pupunha (LEITE,2013:33), pois se trata de outra natureza, embora mantenha a mesma cultura (comer e plantar pupunha, seja lá o que isso signifique para o interlocutor). Para Kelly, um processo similar se dá no âmbito social, das relações políticas, onde, baseado em Wagner (1981), descreve a obviação utilizada pelos Yanomami na relação com os napëpë: obviar, aqui, é um método inventivo de mascarar relações, atribuindo outros significados ao seu conceito original. No caso, refere-se às transformações em napë e dos napëpë em Yanomami, na condição de possíveis aliados. No caso testemunhado por mim, no Toototopi, percebo esse tipo de procedimento para identificação crítica de potenciais aliados, dentre os profissionais de área, onde identificavam diferenças visíveis dentre aqueles que se esforçavam por falar a língua, se interessavam pela vida dos Yanomami e outros que mantinham distância e alheamento.

Ouvi de Jeremias, witipii thë kahihihou tha? Huutihipë hehuoti mothoka kua makii ${ }^{22}$ (hиu tihipë: "madeira", nesse caso, é a porta. Hehuoti, uma forma de ação contínua: está sempre trancada)... deixando claro: 'somos yanomami, não roubamos não'. Ele apontava para os nарёрё no posto, sempre trancados principalmente evitando a convivência social com os Yanomami. Não é necessário dizer que a curiosidade torna-se uma cobiça, e em franco choque com a economia racionada dos postos. 
Kelly (2011) descreveu situações semelhantes para os yanomami na Venezuela, não devo relatar casos, mas informar a semelhança dos diversos pontos de tensão entre Yanomami e os profissionais da saúde, com características similares; a organização disciplinar e as diferenças de etiqueta de praxe: sovinice (xiimamuwi) atribuída a uns, oferece o contraponto da condição de pedintes imputada pelos outros. As tensões costumam diminuir consideravelmente quando o atendimento se dá nas residências Yanomami, especialmente quando o técnico de saúde se entrega a sua condição minoritária e é capaz de se despir de suas defesas e desconfianças. É propriamente a condição exposta por Wagner (1981:29) de abandonar momentaneamente a certeza de suas convenções sociais para se permitir a compreender o outro.

Sobre o ato de sovinar, observei em representantes da nossa sociedade alguns expoentes tinham como meta buscar o bom negócio: conseguir as coisas negociando menor custo. Embora o desafio de sobrevivência implique algum bom senso na distribuição de utensílios com os Yanomami, mas a postura recorrente de conseguir as coisas com um artificio similar ao pensamento colonial de exploração da matéria prima, mas os artefatos yanomami eram essencialmente depreciados. Vi trocas de um cesto por um sabão. Uma postura, à microescala, similar ao nível de Estado, de colônia, exploração de periferia do sistema mundo. Essas pequenas atitudes os Yanomami sempre detectaram como injusto, sem necessariamente negar a troca.

Os trabalhadores de área na Terra Yanomami são em geral oriundos de Boa Vista, migrantes ou não, e consequentemente, muitos têm relações históricas com o garimpo que assolou a região na década de 1980-90. Muitos são filhos de garimpeiros, ou ex-garimpeiros, e tem no trabalho com os povos indígenas uma relação de assalariamento mais do que uma causa de motivos ideológicos, humanitários; ora tal consciência aparece, pelos motivos afetivos de relações criadas com seus pacientes/colegas. Nas relações que testemunhei, algumas pessoas mantinham uma relação afetiva com os yanomami, assumindo as trocas e os presentes, as conversas sobre os parentes, e outras questões de interesse mútuo; já outros casos, mantinham um distanciamento e sobretudo desdenhavam de vários aspectos dos Yanomami, consideravam-lhes traiçoeiros, capazes de roubar etc. Alguns que passaram pelo Homoxi julgavam que os Yanomami tinham tido envolvimento com o garimpo, tentando lhes desqualificar a crescente luta anti-garimpeira. Uma afirmação desse tipo é uma desconsideração histórica do contexto de contato nessa região, iniciada pela presença 
garimpeira antes de outra; O processo de invasão inicia-se com os garimpeiros ainda em minoria, estabelecendo relações de favores e ofertas de vantagens que logo, quando passam a ser maioria, são substituídos por uma relação de hostilidade cada vez maior, menosprezando os Yanomami, que se tornam um incômodo para a atividade garimpeira, tal como explícito por Albert (2001[1993]) quando relata o massacre de Haximu, em 1993.

Os trabalhadores dos postos de contato tem assim a oportunidade de se sensibilizar pela experiência exotizante de conviver com um povo da floresta, ou poderão simplesmente não se despirem das convenções de sua cultura, não levar tal experiência como um aprendizado sobre sua sociedade e seus interesses econômicos e coloniais. Alguns aprendem a falar a língua, dedicam-se de fato à tarefa de garantir atenção à saúde dos Yanomami no percurso de todas as posições onde possam estar os Yanomami. Foi perceptível para mim e outros analistas atentos a mudança de comportamento dos Yanomami conforme o interlocutor, numa reciprocidade em relação à forma com que são tratados. As relações eram, por exemplo, menos tensas no Posto Yano, no Parawau, um posto de arquitetura aberta em que os Yanomami respeitavam espaços de quarto, mas tinham acesso às áreas de convivência, ao mesmo tempo que equipes participaram de acordos tácitos de convivência. E variaram no Toototopi conforme a equipe e os modos como se posicionavam em relação aos seus anfitriãos. Ouvi da parte de vários profissionais de saúde mais afeitos ao convívio, ser o cotidiano 'nas malocas' mais agradáveis, onde a tensão vivida no posto (enquanto casa dos napë) se dissipava. Mas a postura era essencialmente diferente, obrigando muitas vezes a terem uma enfermagem, um espaço exclusivo da saúde mesmo nas casas Yanomami.

No aprendizado político dos Yanomami, alguns documentos demonstram uma análise sofisticada do próprio processo vivenciado do atendimento à saúde. O fim do convênio de saúde com a Urihi (2004) deixou a possibilidade de se estabelecer comparação, prontamente realizada por anciãos e jovens trabalhadores da saúde: o documento abaixo foi escrito pelos Yanomami, traduzido pelo falecido Jornalista e Historiador Luis Fernando Pereira (Wixaxina $^{23}$ e publicado pela CCPY, Comissão Pró-Yanomami ${ }^{24}$ :

23 Trad.: 'rabo de macaco cuxiú', em referência ao cabelo comprido e preso que frequentemente usava

24 disponível em: (http://www.proyanomami.org.br/boletimMail/yanoBoletim/html/Boletim_53.htm), datada de julho de 2004 e acessada em 29/05/2017; esclareço aqui que Funasa, Fundação Nacional de Saúde foi a instituição responsável pela saúde indígena desde 1991 até a criação da SESAI (Secretaria Especial de Atenção à Saúde Indígena) em 2010 
A vocês da Funasa.

Nós fizemos o que chamam de reunião, é uma tentativa de acertarmos o que está acontecendo. Como nós pensamos sobre os brancos que estão trabalhando com a nossa saúde agora? Nós não pensamos à toa, porém não temos ainda uma opinião definitiva.

Vocês da Funasa não trabalham como trabalhavam antes os da Urihi, mas nós vamos tentar corrigir isso. Os brancos da Urihi trabalhavam bem. Se estávamos com saúde aqui, eles seguiam para outra casa onde houvesse doenças, sem pressa de retornar para o posto. Era assim que eles faziam, trabalharam muito em outros lugares. Depois de curarem os outros Yanomami, somente após isso, eles retornavam para casa. Eles também detectavam doenças lá longe, entre os Maxapipiwei teri pë, era assim que eles faziam, os da Urihi.

Vocês da Funasa não fazem da mesma forma que a Urihi fazia no passado, mas nós vamos insistir para que melhorem. Se hostilizarmos os da Funasa à toa, não virão outros brancos aqui para nos curar. Por isso fizemos esta reunião, para tentarmos conscientizálos.

Se não dissermos "Ajudem-nos, vocês da Funasa", vocês não nos ajudarão, vocês não nos responderão. Talvez vocês digam "não, os Yanomami não pensam direito". Nós dizemos: "Nós não queremos que nossos filhos morram, eles já morreram demais no passado". "Não sejam preguiçosos", "vá até minha casa". Quando falarmos desta forma, vocês devem ir. Vocês da Funasa que entraram na nossa terra, não sejam preguiçosos.

Nós estamos vigiando, estamos atentos, de olho na administração de remédios. Nós estamos observando diretamente se a pneumonia acaba, se nos curam bem. Agora, se o pessoal da Funasa ficar bravo à toa, afugentar crianças e também reclamar, aí vamos ter vontade de nos livrar deles. Se não nos curarem, não será nada bom.

A Urihi trabalhava assim: eles iam para o Koherepi, para o Uxiximapiu, para o Maxapipi, para o Raharapi, para o Etewexipi. Era assim que a Urihi atuava, por isso os Yanomami ficavam realmente muito felizes. Mas a mulher da Funasa nos mandou para trabalhar para eles. As crianças estavam doentes, mas a mulher da Funasa nos fazia trabalhar. "Come peixe!". "Depois de comer, você deve curar as crianças", nós the dissemos. Se não curarem nossos filhos, não queremos trabalhar com vocês e vamos querer dizer que "a Funasa não é boa". Isso vai acontecer se nossos filhos morrerem de pneumonia ou de outras doenças. Aí, não queremos mais ter vocês da Funasa por aqui. "Vamos chamar outros brancos realmente bons", é isso que vamos dizer, se isso acontecer.

Nós também dissemos aos da Funasa que foram à nossa casa: "Vocês devem trabalhar como faziam os da Urihi até recentemente". Mas eles nos chamaram de preguiçosos quando não fomos pescar para eles, após dizerem "estou com fome".

Outro assunto. Há microscopistas entre nós, Yanomami, mas se não tiverem o que fazer, a situação vai piorar, por isso queremos voltar a atuar com a Funasa. As coisas ficarão boas quando voltarmos a trabalhar como na época da Urihi. Ainda lemos lâminas, ainda sabemos ver a malária. Nós queremos continuar a trabalhar, mas não nos dão o que fazer. Vocês também estão inativos, por isso estamos tristes.

Episódios como esse acabam por justificar o quanto um contato esclarecido e baseado nos direitos humanos favorece a sobrevivência dos Yanomami frente às ameaças do mundo 
atual, mesmo com os inconvenientes. No texto acima assinado por um grupo de Yanomami da região do Posto Yano, Parawau, fica clara a intenção de orientar os napëpë, de conscientizalos sobre o que experienciaram sobre atendimento à saúde com o trabalho da Urihi. A carta relata outra questão exposta nesse capítulo sobre o trabalho intercultural: a dificuldade de expoentes de equipes de saúde no posto com a subalternização dos Yanomami, chamados a caçar e pescar para eles; e também demonstram que não querem apenas atendimento, mas querem envolvimento, querem trabalhar juntos, serem responsáveis pela saúde e adquirirem competência nesse campo, quando falam dos microscopistas Yanomami (parte dos quais assinam a carta).

A formação dispensada aos Yanomami nos postos de contato, as primeiras lições de "mundo branco", e as consequentes intervenções no âmbito da educação intercultural os levou a se organizar e se defender através de sua organização (Hutukara Associação Yanomami), capaz de influir nos destinos das políticas públicas, utilizando meios reconhecidos pela Sociedade de Estado (NILSSON 2011). Para que tal acontecesse, foi necessário que os Yanomami vivenciassem um sistema de saúde que respeitasse, reconhecesse e contemplasse seu modo de vida e de conceber o mundo (sua cosmologia), incluindo aí o xaporimou (xamanismo) e a sua mobilidade inerente. A complexidade de problemas de seu território aparece nos depoimentos Yanomami, que elaboram progressivamente uma reflexão sobre o outro, um outro que é gerador de problemas, uma vez consciente disso, pode ser também responsável por soluções.

Os Yanomami tem um desafio de reconhecer dentre os tantos outros que lhes aparecem, aqueles que podem ser potenciais aliados. Parte dessa demanda é executada com o olhar nos olhos do outro, com um tipo de saber precisamente subjetivo, e se desenvolve numa 'ciência da alma', na admissão de uma ciência com sujeito, uma psicologia, por assim dizer, de cunho humano ao qual os Yanomami (felizmente) não incorporaram nossos métodos científicos objetivos no desenvolver dessa habilidade.

A compreensão dos processos políticos que podem ameaçar seus direitos necessita de uma vivência histórica de lutas contra as ameaças, nem sempre prefiguradas em pessoas concretamente, mas muitas vezes em papel, esse modo de os napëpë das sociedades de Estado lhes suprimirem direitos, dificultando, pelas distâncias, a possibilidade de resistência. A aliança entre Davi Kopenawa e os seus napëpë que o apoiaram e o assessoraram no embate 
com as sociedades de Estado torna-se uma necessidade; foi ela que possibilitou uma expansão das experiências de luta de Davi para outros expoentes, com os quais faz da Hutukara um instrumento para cumprir a missão de proteger sua terra. Processo educacional longo e custoso desenvolvido após a tese de Bruce Albert e a formulação do conceito de vacina etnográfica.

Os postos de saúde são a primeira possibilidade de convivência intercultural para muitos, mas a aquisição de competências para lidar com os não Yanomami depende de uma atenção maior e uma elaboração também mais complexa, conforme foi a missão do PEI em alimentar com questões do mundo dos brancos que diretamente afetam os Yanomami, com a tarefa de alertar para os perigos invisíveis que os interesses econômicos sobre as terras indígenas impõem: a constituição de 1988 (BRASIL, 1988) não garante ao subsolo o mesmo estatuto de 'direito de usufruto exclusivo' dado à terra, portanto, os povos indígenas têm lutado na arena dos papéis, nas leis, contra o projeto de mineração em terras indígenas, dentre outros (ALBERT, 1991) que também os afetam. Enquanto no caso do posto de contato, deslocar-se para longe já significa um arejamento frente às condutas dos napëpë não yanomami do posto; no caso das outras ameças elas não cessam se não há uma resposta na arena dos papéis. De certa forma, foi essa radicalização da antropologia reversa wagneriana que guiou o trabalho do PEI, sob orientação e consultoria de Bruce Albert que garantiu uma maior competência para lidar com o mundo dos brancos.

\section{Apontamentos finais}

Os Yanomami têm se mostrado interessados e envolvidos nos ensinamentos e na absorção do conhecimento e explicação tal como apresentada pelos napëpë que compõem o sistema biomédico e seus apoiadores. De maneira nenhuma, no entanto, abandonaram o seu sistema próprio de conceber o mundo vivido. Dessa forma, tais novos conhecimentos não se mostraram incompatíveis com a explicação Yanomami dos processos de enfermidade, parecendo conviver em planos distintos de abordagem (RAMALHO, 2008). De certa forma, os Yanomami estranhavam a não percepção dos aspectos xamânicos dos fenômenos patológicos pelos profissionais de sáude. Enquanto os sistemas conviveram, isso não representou um choque ao modo de pensar Yanomami. Em outras ocasiões, por exemplo quando a missão Novas Tribos do Brasil (antiga New Tribes Mission) comandava o contato no Posto Toototopi, havia uma perseguição maior ao xamanismo e às práticas xamânicas. Isso é relatado por Davi em sua Auto-biografia (KOPENAWA e ALBERT 2015). As 
incompatibilidades dentre os modos de compreensão xamânica com a religiosidade cristã implica em resistência dos Yanomami frente à empreitada proselitista. O deslocamento da missão para o Rio Demini a montante da foz do Toototopi foi uma iniciativa dos Yanomami, e foram seguidos pelos missionários. Paradoxalmente, no Novo Demini permanece habitante um dos maiores xapori dessa região. Ele, por sua vez, soube aliar a escrita, contribuição dos missionários, e o xaporimou, conforme relatado por Lidia Montanha Castro (CASTRO, 2013), na construção de um caderno de xamanismo, a ela ofertada enquanto objeto de estudo.

Utilizando habilidades já desenvolvidas na vida da floresta, os Yanomami desenvolvem competências para operar com diversos equipamentos, mas principalmente ferramentas conceituais dos brancos. Outros aprendizados se deram não tanto na forma objetiva e material das habilidades em lidar com ferramentas alienígenas, mas em perceber nos estrangeiros suas atitudes colonialistas, desdenhosas, expressas em pequenos atos, mas suficientes de sua índole e do que pensavam perante aos seus anfitriões. Entender melhor o português implicava em decifrar as intencionalidades nas falas dos napëpë, quando eram ou não ofensivos em função das incompreensões nas relações interculturais. E também perceber nas equipes aqueles mais sensíveis às especificidades dessa relação, de alguma forma demonstrando maior afeto aos seus clientes do sistema de saúde (dentre outras).

A condição de anfitriões hegemônicos e razão de existir dos postos de saúde, colocam aos Yanomami uma segurança maior em lidar com o napë $a$, inimigo no conceito, mas relação cada vez mais necessária. Tal configuração de inferioridade numérica de fato contribui a uma compreensão que leve ao fortalecimento das defesas perante a uma ameaça desproporcional que representa as sociedades de Estado perante os Yanomami e a terra à qual pertencem. Inclusive percebendo um movimento de afastamento do posto concomitante à aproximação, como um movimento de defesa aos incovenientes de uma proximidade excessiva aos napëpë. O que os Yanomami esperam dos napëpë também fica expresso na sua postura, bem como no documento aqui republicado, que os respeitem como gente e visitem cada povoamento Yanomami, saindo do posto e reconhecendo que todo profissional de saúde deve ir onde o povo está. 


\section{Mobilidade Yanomami e política intercomunitária: Acordos territoriais no Toototopi}

\section{Mobilidade Yanomami e acordos políticos no Toototopi}

Os Yanomami discutem, discursam e dialogam: obstinam-se no debate político em busca de consensos sobre as questões que possam gerar discordância. Esse capítulo foca no meu testemunho no Toototopi durante o período entre 2001 e 2006, sobre os acordos territoriais nessa época desenvolvidos, e analisa a centralidade do posto nessas discussões, por representar um espaço diferenciado para o conjunto da região. Aponta então para as soluções políticas definidas e acordadas pelos diversos grupos ali residentes.

Embora, no relato a seguir, haja um certo enaltecimento dos modos de organização dos Yanomami, é preciso ter sempre como pano de fundo os desregramentos, a indisciplina, uma desordem inerente à recusa de governo, carregado de futricas a causar estranhamento e perplexidade ao não-Yanomami criado sob as Sociedades de Estado, o napë cujo desejo de ordem e explicação característico de nossa mentalidade não consegue alcançar lógica nem explicação alguma. Nossa estranheza demonstra uma certa naturalização das formas de organização de Estado em nossa mentalidade, embora esta tenha se consolidado num período muito recente da existência da humanidade. Advogo aqui que as formas de organização descentralizadas são possíveis, ainda que impliquem um esforço teórico em observa-la como organização, quando muitas vezes ocorrem episódios de 'descontrole' sob os olhos dos nãoYanomami, acostumados ao poder central.

Episódios de conflitos no Toototopi não diferem muito dos já descritos por antropólogos para outras regiões, debatidos quanto às suas causas (CHAGNON; HAMES, 1979; HARRIS, 1984; CHAGNON, 1988; ALBERT, 1989; FERGUSON, 1989; GOOD, 1989; 1990; LIZOT; DART, 1994; FERGUSON, 1995), embora com sua dinâmica histórica própria; não se trata de uma região de conflito e inimizade endêmico. Aglutinados a partir da instalação da Missão Novas Tribos na década de 1960, os grupos de alianças intercomunitárias incluem os Hawarihipi que a Missão se agregou desde sua origem (e os acompanharam para o Novo Demini), os Sinatha theripë, os Warëpiu theripë, os Kokoiu theripë, os Maraxipora, os 
Wanapiu compartilhando a região a mais de 30 anos, acrescidos de outros grupos mais recentes, posteriores à instalação da missão, como os Paxotou e os Moheresipiu theripë (que vêm a formar o Xiroxiropiu). A representação da doença e da morte pelos Yanomami, geralmente imputadas a um inimigo, resulta em consequentes vinganças (ALBERT, 1985). Em textos posteriores, Albert alerta para a consequência de uma disjunção sanitária como a registrada em tempos de invasão garimpeira de seu território. Pois as inimizades aumentam quando há mais óbitos até o reconhecimento da etiologia da epidemia (xawara) ser imputada aos forasteiros napëpë e suas fumaças venenosas, conflagrando uma situação onde não implicaria em vingança ritual (ALBERT, 1997a). Foi o caso da famigerada "epidemia do Oswaldo" (osvaldo a wai; Oswaldo Leal fôra funcionário da Comissão de Limites, em 1943 e teve o contato com os Yanomami marcado por inimizades, tentativa de assédio culminando com a propagação), responsável por uma forte epidemia à época do contato, mas cujos óbitos não resultaram em vinganças, pois claramente reconheciam ser ele, e suas fumaças venenosas, o causador da epidemia xawara.

Albert (1985) demonstra como as alianças intercomunitárias são centrais no sistema de organização social dos Yanomami; no caso do Toototopi, um local onde esses vários grupos de origem distinta se agregam, compartilhando um mesmo território, a atualização teórica sobre o papel da alteridade parece ser central para a coexistência dos vários grupos, num fantástico entrecruzamento de caminhos e residências, como veremos nas descrições espaciais desse capítulo.

A narrativa abaixo tem relação direta com a instalação de postos de saúde na região do Toototopi e suas dinâmicas de relação interétnica, cabe lembrar de estudos que já trataram do mesmo tema em outras regiões povoadas por Yanomami (KELLY, 2011). Jose Antonio Kelly relata, para o atendimento à saúde na Venezuela, os mal-entendidos relativos ao contato com o sistema médico, onde, de um lado, os Yanomami são tratados como capazes de roubar e os médicos e profissionais da saúde como sovinas (xiimi), incapazes de estabelecer uma saudável relação de troca. A troca de utensílios materiais (matehipë ${ }^{25}$ é mediada por uma relação de

25 Não parece-me adequado associar a palavra utilizada para tais bens, matehipël matohipë à nossa idéia de mercadoria, bens de troca, já que a palavra yanomami originariamente tem relação com objetos rituais tais como as cabaças que guardam as cinzas funerárias poraaxihi etc (KOPENAWA; ALBERT, 2010). Tal associação, uma vez que são objetos úteis (utensílios), e são trocados (mercadoria) sob um regime em que sua posse não parece ser a maior importância, mas seu uso; bem distinto de nosso objetivo com mercadorias, que implica em acumulação de valores através da troca. A polissemia da palavra matehipë, aproxima-se mais de "utensílios", que melhor traduz para ambos os sentidos culturais 
alianças (ALBERT, 1985), diferentemente dos significados que lhes atribuímos como mercadorias.

O Toototopi tem sido caracterizado recentemente e em boa parte das situações testemunhadas por mim como um lugar onde o desentendimento entre equipe de saúde e parte das populações yanomami eram frequentes, com acusações mútuas e desconfianças recíprocas. Nesse contexto, era comum ouvir os velhos anciãos, as lideranças reconhecidas dos Yanomami, os pata thëpë lamentarem de eles aconselharem os jovens, mas esses, muitas vezes, desobedecerem. Relatar a capacidade de organização dos Yanomami em busca de uma maior equidade territorial de acesso ao posto deve ter como pano de fundo as ressalvas acima e considerar que o resultado, além de provisório, não se parece em nada com nosso modelo de ordem (claro está que nosso modelo também não corresponde ao nosso cotidiano!).

\section{Reunião: deliberação e efetividade}

No Toototopi, testemunhei uma reunião, um hereamu, em que algumas discussões sobre as ocupações yanomami, os assentamentos em relação à proximidade do posto, tido como fornecedor de serviços que resultam em acesso a utensílios matihipë e outras vantagens. A reunião originou-se das constantes queixas relacionadas ao atendimento à saúde, em que a visita ao posto implicava em dificuldades com alimentação, dentre outras. Havia uma consideração entre os grupos que se utilizavam do posto de que alguns eram privilegiados por estarem próximos, por se beneficiarem da presença dos napëpë como fonte de utensílios; isso era de certa forma visto como uma apropriação. Lembro-me de várias situações em que os yanomami se referem aos napëpë como propriedade, "o meu napë"... daí se depreende a importância de se estar próximo do posto.

Durante essa reunião decidiu-se por todos se manterem distantes do posto. A maioria nesse momento já havia se distanciado, eram os mais próximos: a) o grupo Apiahiki, originário do Sinatha, junto com os Piau, desde quando se separaram, no Rapahiki; b) o Kokoiu em 2002 havia sido trocado por duas casas na beira do Rio Wayahanau (denominação Yanomami do Rio Toototopi), o Rasasi, e o Kaxitao, dada a falta de água do pequeno riacho Kokoiu, e mesmo o Pia u, bem maior, onde já moraram. A decisão dessa reunião foi de providenciar, cada grupo, provisões para quando fossem ao posto de saúde ter uma casa de apoio próxima ao posto ou ao rio e outro ponto longe, representando a atual moradia de cada um. 
A movimentação de aproximação ou distanciamento do posto foi negociada então nessa época (2003) e demonstra habilidade política na negociação entre grupos comunitários numa região geográfica compartilhada; partindo dos problemas enfrentados quando a atenção a saúde os obriga a visitar o posto. Numa reunião Yanomami, 'quem cala, não consente', no sentido de que: uma vez chegado a uma consonância de opiniões mais ou menos claras nos discursos, mesmo que com divergências, todos opinarão sobre a proposta, em acordo ou não. Caso haja discordância ao final dos pronunciamentos, a discussão volta aos primeiros, numa busca por um consenso o mais abrangente. Essa proposta passou por isso, incluindo mulheres que discursaram como todos os homens pata thëpë, vários por comunidade. Houve reafirmação da oposição a qualquer invasão por não Yanomami, e as ameaças eram conhecidas deles que sofreram o trauma do garimpo, também foi tema, com todos protestando contra o PL de mineração em terras indígenas (PL 1610/1996), à época iminente no Congresso. Assuntos de peso como este foram esclarecidos em toda a comunidade.

A maturidade de as discussões territoriais logo alcançarem um acordo sugere o quanto a discussão política de fatores relevantes às suas vidas favorece a convivência intercomunitária. Tal capacidade de negociação se mostra evidente em outras circunstâncias, quando analisados os discursos como os diálogos cerimoniais de Wayamu, realizados em reahu ou em ocasiões como assembleias (KELLY, 2015). Nas cerimônias de reahu, como um todo, transparecem relações de tensão e de busca de sua resolução, sempre combinadas com os demais aspectos da vida, os encontros matrimoniais, as cumplicidades das alianças frente a inimizades, todas essas negociações convergindo para uma convivência real entre aliados, em frequente negociação. Nesse caso, tratava-se, não apenas de dividir a mesma região, mas igualmente os mesmos napëpë.

Após essa reunião, estive no Toototopi por mais vezes, especialmente 2005-06. Nesse ano, a configuração espacial incluía um conjunto de segundas residências, antes inexistentes: uma, construída pelos habitantes do Piau, ocupava uma localidade do outro lado do rio, bem próxima ao posto, próximo a uma localidade outrora ocupada pelos atuais Maraxipora, e depois pelos Xiroxiropi. Ali permaneciam os Piau, quando próximos do posto. Outros como os Wanapiu, que residiam, à época a três horas e meia do posto, construíram um conjunto de 
tapiris naanahip $\ddot{e}^{26}$ nas capoeiras que circundam a pista de pouso, com uma roça de Manihot sp. hutusiki. Foi uma mulher Yanomami quem me alertou para a relação entre aquela nova casa e a decisão ocorrida naquela reunião de 2003. Os Yanomami haviam se posto em movimento por detectarem problemas que poderiam ser assim resolvidos.

Considerando as dificuldades de se implementar roças, casas e estruturas para comunidades de populações em torno de cem pessoas, era de se esperar que essa decisão fosse uma conversa sem grandes consequências, daquelas em que se constata um problema, sem tanto empenho na efetivação das ações para resolve-lo. Porém, já no ano seguinte à reunião, a situação já se encontrava desenhada, com as casas e roças próximas ao posto já construídas.

Em 2006, quando os Yanomami organizaram um curso de formação no posto do Toototopi, com nossa participação nas questões pedagógicas, presenciamos reunião na casa nova do Piau 'do outro lado do Rio Toototopi' (Wayahanau pikatureha como se referiam a ela), os Yanomami se diziam 'moradores' dali, haviam se mudado; perguntei sobre o Piau (com esse nome devido a ser à margem do homônimo afluente do Rio Toototopi), se eles haviam abandonado 'jogado fora' e responderam não, estavam momentaneamente residindo ali, próximo ao rio principal da região. Num ano podem morar em uma casa, no ano seguinte voltando à posição anterior. Uma pessoa desavisada poderia supor se tratar de uma mudança de residência de fato, ainda podendo concluir erroneamente, através de um momento da história, que se tratava de um processo de atração provocado pelo posto. Vejamos o depoimento de Enio Mayanawa, à época professor do Piau, sobre o contexto em 2005:

Hekura yano Boa Vista, 01 de junho de 2005

Awei kami ya noa pree weemu pihio, awei hapënaha thë waisipë, kuai kami yamakiha escola a totihi kua makure ai yamaki huai xiwaripru mahi kuë yaro kamiriha thë xaari mahiimi, komi yamaki yai kuo tëhë thë yai xaari, ai urihihami yamaki huai piyëkuu tëhë thë yai hoximi

Kami yamaki komi xaari kuotëhë kamiriha thë xaari, ai urihihami yamaki huu piyëkuu tëhë thë xiro hoximi mahi, kami yamaki pirio poaowiha thë pëha waromu kunaha thë xiro xaari.o

Kaxitaõ hami ai yamaki pirio pihio, inaha kuë yaro thë waisipë hoximaa, posto ahetehami

26 tapiri é um termo oriundo do tupi nhengatu, que refere-se a pequenas cabanas de palha para pernoites temporários. Passou a ser usado para naanahi, termo Yanomami que representa algo similar, mas nem sempre: quando se vai construir uma nova yano, a residência circular Yanomami, seja pela mudança de local, ou pela deterioração da primeira, são feitos naanahipë em que os co-residentes habitam, até a definitiva construção da yano 
yamakika kutaiwi yamaki xiro mii kutai puo, yamaki yai pirio pihioimi, porimoxitëhë yamaki xiro kutai puo, kami yamaki mau upë wehe pru tëhë, posto aheteha yamaki yai pirio mahioimi, inaha thë kua makure kaxitaõ hami ai yamaki xerekea yaro thë xiro waisipë hoximaa, kami yamaki escolapë hoximaimi, escola a yai totihi kua, kami yanomae yamaki xiro hoximaai, Piau hami 2 yano kipë kuamakure mori escola akua, tha yamaki komi estudamu, yamaki piria ahete yaro, iht thë totihi makii kami yamaki xiro waisipë huai tikoo.

Inaha kuë yaro kamiha thë waisipënë aipë, awei piau hami kami yamaki piria xoa, ai urihi hami yamaki huimi, awei kami yamaki thë kuaiwi ya thë ã thai pihioma, kuë yaro hoyamaki thë $\tilde{a}$ kua kami ai yamaki waisipë totihipru maowi yathë ã wawëmai pihioma, awei inaha kure ya thë $\tilde{a}$ wëai pihioma thë ã mahikiprarioma. ${ }^{27}$

Enio Mayanawa Yanomami

A carta versa sobre esse mesmo momento político no Toototopi, demonstra de como a escola era localizada sempre próximo às comunidades. Demonstra principalmente a reflexão sobre o posto, sobre habitar próximo a uma região já por demais utilizada, e que ainda oferece motivo para discórdias, pela cobiça que os napëpë despertavam; a postura dos Piau theri sempre foi de manter uma distância dessas cobiças, expresso nessa carta do professor.

Ocorre que o Piau e sua região permanece como um dos mais importantes pontos de morada da região, tendo sido inclusive o palco da devolução do sangue ali colhido e levado para universidades e centros de pesquisa norte-americanos e lá permaneceram até a intervenção em favor de sua volta, para passar pelos devidos cuidados funerários (ALBERT, 2003; DINIZ, 2007). O já histórico terreno do Piau permanece com uma população importante, possui hoje uma pista, inexistente naquele tempo,vinculado ao sistema de assistência à saúde (Sesai); essa segunda residência que me refiro aqui, hoje já não existe, tornou-se desnecessária com o descentramento que culminou com a construção da pista

27 Eu também gostaria de comentar, está um pouco assim: para nós, apesar de a escola estar bem, outros de nós tem andado por aí sem muita razão, por isso, para mim não está nada certo, se todos nós comparecermos, é que estará correto, se formos constantemente para outra floresta uma após a outra não será positivo.

Se todos nós fizermos o certo, para mim será melhor, se formos para outros lugares seguidamente é que será muito ruim, nós morarmos por aí divididos, se eles tivessem chegado seria o correto. Outros de nós querem viver no Kaxitao, o que é um pouco ruim, por a gente ficar próximo demais do posto, nós não podemos ficar à toa, nós não queremos morar aí apenas a toa, se nossa fonte de água secar, perto do posto nós não vamos morar demais, e porque alguns de nós querem se dividir e morar no Kaxitao é que é um pouco ruim, nossas escolas não estão ruins, temos uma boa escola, nós Yanomae é que estamos atrapalhando, no Pìau existem duas casas grandes, mas apenas uma escola e lá nós todos estudamos juntos, pois nós moramos próximos, e isso é legal, mas as pessoas continuam por aí a toa, sem razão. Por isso me parece que estão virando outros, sim, nós ainda vivemos no Piau, nós não vamos a outro lugar, sim, eu queria falar do nosso jeito de fazer, por isso sobre o fato de alguns de nós não estarem com as atitudes aprumadas eu queria esclarecer, e eu já alertei, por fim. 


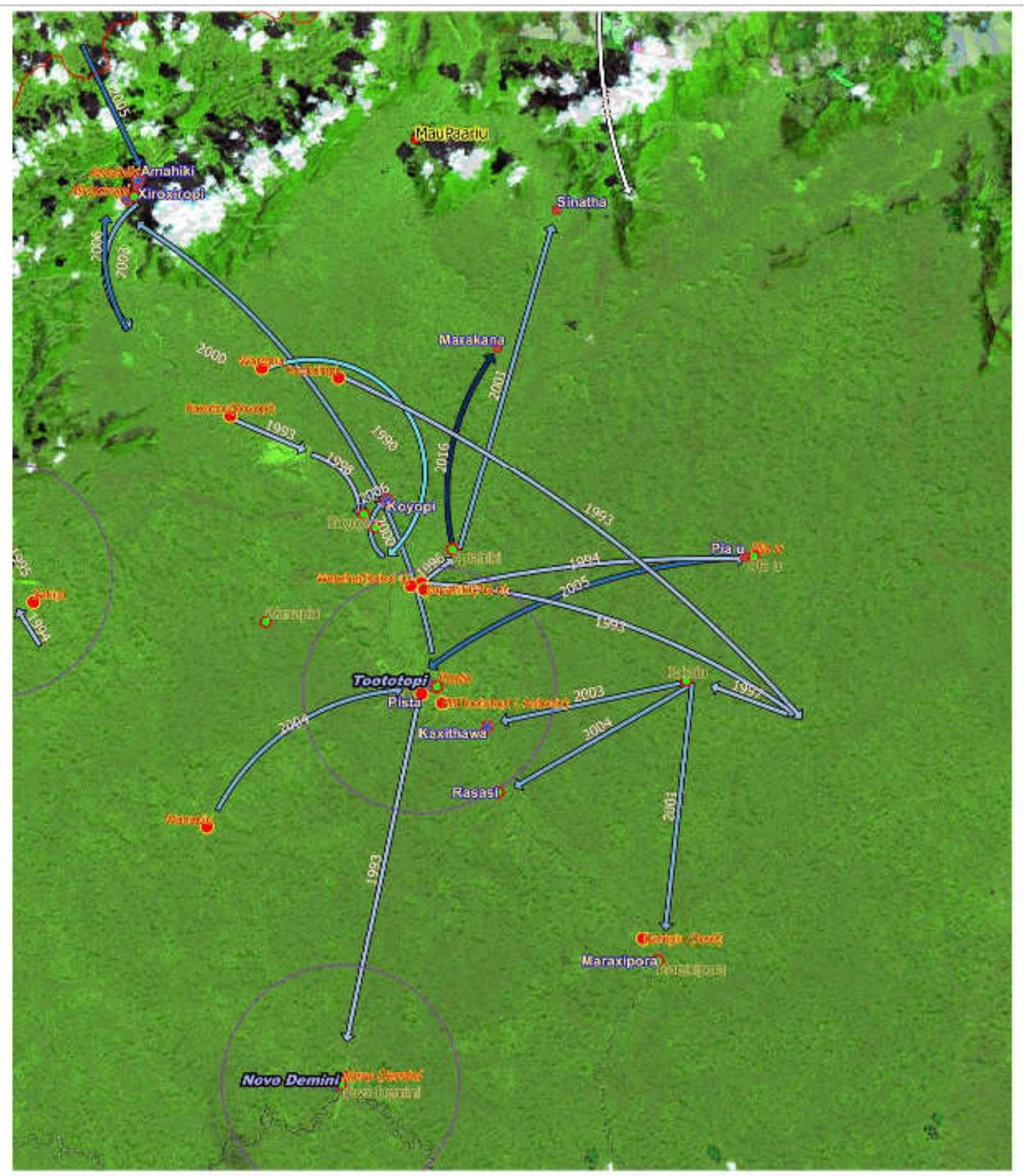

\section{Legenda}
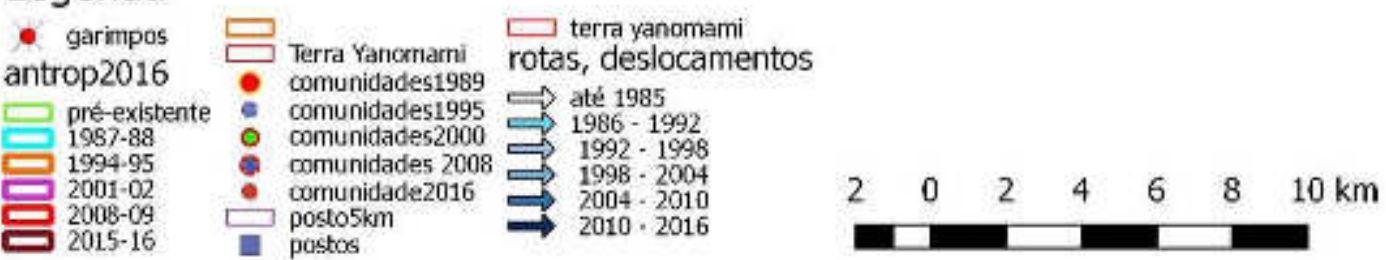

Figura 10: mapa das movimentações no Toototopi dentre 1987 e 2009, com as localidades citadas no texto. Os nomes duplicados indicam a permanência do grupo no mesmo local durante mais de uma temporada de análise. E sobre as setas está indicado o ano aproximado da mudança. 
A Figura 10 apresenta um mapa com a espacialização de trajetórias descritas nesse trabalho. Note ali o Piau já descrito, mas veremos que a sua origem, num curso menor em relação à calha principal tem relação a um descentramento ocorrido em 1993 em diante.

\section{Maupaariu: evento marcante}

No início dos anos 1990, a invasão garimpeira alcança as cabeceiras dessa bacia, num braço do Wayahanau, denominado Maupaariu. Nessa localidade, próxima à serra, os garimpeiros construíram pista de pouso e a atividade minerária já havia poluído toda a calha principal, mudando a turbidez da água, sua potabilidade. Tido como evento menor, e considerado um evento improvável, diante de outras invasões maciças, o garimpo na região do Toototopi foi datado, restrito apenas ao início dos anos 1990, mas resultou na consciência sobre os perigos dessa atividade para as condições sanitárias e provocou um esforço que reconfigurou a distribuição das habitações no Toototopi.

Reproduzo aqui o relato de Gonçalo, do Wanapiu, dando conta da surpresa de encontrar garimpeiros numa região que se acreditava isenta deles, atraídos em sua maioria para o alto da Serra Parima e adjacências, ao norte. O texto é resultado de uma aula na escola de sua comunidade em 2005, na residência secundária construída nas capoeiras da antiga missão, à época do acordo territorial relatado acima (ainda em 2003).

Hapa o tëhë wayahana u ora hamë marakanã hamë garimpeiro pë ni waroho kuoma, mau Paari u ha hapa kiama. Inaha kua yaro garimpeiro pëni mau wariaremahe. maquinário pëni mau yai hoyapramahe prahai hamë kua yaro mau waiu kakii yai maprarioma u wehepramaremahe yayua hamë u hoyakemahe kasiki hamë yokota pë xiro payukurayoma.

Marakanã aha wayahana u kasi ha pista a thapomahe. thapoma makihi Wayahana u harani Waiu ha ai pista a thaakõkemahe tharani hehupë hamë waiu yamowi hamë garimpeiro pë kiai yamohayoma

hehuhamë mau pë pree hoyama Inaha thë thama yarohe mau yai haikiarema. $u$ mapramaremahe.

Roahikatiopë uharani peri yoha yanomae thëpë rooma yaro kama pë ni garimpeiropë taaremahe thi tëhë yanomae thë pë noa thayoma. thi tëhë impacto ambiental yama thë thapranimi yaro garimpeiro pë noamamahe. Yanikini garimpeiro pë orayoma waroho kuprarioma yaro thëpë xuhurumoma missonário pë ha thë ã wëaxoakemahe thi tëhë missonário napë kipë huxoaoma. kipë huxoaowi urihiha garimpeiro kuo tëhë kipë warokema.

Roahikatiopë u harani garimpeiro pë kopema Toototopi ha pista aha thë pë kuoma. thëpë kuowi missionárioni avião aha nakarini thëpë kõoruhuruma. thi tëhë missionárioni yanomae pata thëpë ha makarini thëpëha kokapramarini thëpë hereamuma thi tëhë Toototopiha garimpeiro pë kopema yaro mokawa a tëremahe garimpeiro pë ha thëpë hereamuma: "Ipa urihi wama thë xamimarema yaro wamaki rukëmaikõo pihioimi ipa wama thë urihi warianomai" pë yai noathamahe. ${ }^{28}$

28 No passado, no alto rio Toototopi (Wayahanau), no Marakanã, muitos garimpeiros estiveram ali, trabalharam no Maupaariu. Portanto, os garimpeiros poluíram a água. Os maquinários fizeram a água jorrar para 
Conversando com outros velhos do Toototopi sobre a história, soube que o primeiro garimpeiro avistado na trilha do Roahikatëopëu (onde hoje está instalado o Posto Yano) chamava-se Andrada, fez amizade com alguns jovens hiya pë e maiores pata pë; similar ao que relata Gonçalo, não houve hostilidade no primeiro momento, quando ainda não conheciam o poder destrutivo da atividade que pretendia esse estrangeiro. A compreensão política não é imediata, mas fruto de um aprendizado. Se hoje os Yanomami do Toototopi firmemente rechaçam o garimpo, isso foi fruto de um amadurecimento de ideias. No Toototopi um evento catalizou as descobertas sobre o estranho mundo pós contato: foi a presença de um filho da casa com vivência maior do mundo externo, Davi Kopenawa com vinte e poucos anos. Os Yanomami mantinham relação com os napëpë missionários, e ao garimpo tratava-se do desafio de compreenderem essa outra categoria de napëpë.

Davi conta ter auxiliado essa descoberta, quando da instalação do garimpo em Maupaariu. Já engajado na luta contra o garimpo em toda Terra Yanomami, o Toototopi se mostrava pouco atraente, por ser basicamente uma terra de sedimentos e alguns afloramentos do Escudo das Guianas. A notícia da proliferação da atividade na bacia surpreendeu a todos. Davi já havia presenciado em outras regiões o resultado da atividade para a terra e a desagregação social consequente. O principal fluxo nefasto viria pela água; e quase todos os grupos residiam usufruindo diretamente do Wayahanau, à exceção dos Warëpiu, grupo ligado ao Paxotou $^{29}$, sendo as duas áreas mais povoadas o Rapahiki e o povo agregado à missão. Davi conversou com as principais lideranças patapë sobre os perigos em vista.

longe e por isso o pequeno curso de água secou, eles secaramessa água jogando-a para outro lugar. Nas margens, ficaram lagoas, apenas.

No Marakanã, na beira do Wayahanau eles colocaram pista de pouso. Mas dali fizeram outra pista num local menor, à beira da serra, subindo um riachinho, e os garimpeiros foram trabalhar riacho acima e ali também fizeram a aágua jorrar, e por terem feito isso eles acabaramcom a água.

Vindos do Roahikatëopëu, os yanomami sentaram-se a beira do caminho e então avistaram o garimpeiro e se pusaream a discutir: mas nós não conhecíamos o impacto ambiental, e por isso defendemos os garimpeiros. Aos poucos os garimpeiros cresceram em número e se tornaram muitos. Isso entristeceu o povo e foram falar com os missionários; então dois missionários se dirigiram aos garimpeiros, na floresta onde estavam.

Vindos do Roahikatëopëu, os garimpeiros alcançaram o Toototopi. Depois de os missionários chamarem um avião eles embarcaram e foram embora. E então despois de os missionários chamarem do maiores, juntou-os e debateram o assunto: contaram que quando os garimpeiros chegaram eles pegaram armas dos garimpeiros e a eles disseram: “a nossa floresta vocês poluíram, por isso nós não queremos deixar vocês entrarem, não estraguem a nossa floresta!", eles disseram.

29 conhecido como Cunha Vilar em homenagem ao militar que participara da comissão de fronteiras e morrera em decorrência de afecções ali acometidas 
Pra cima das montanhas tem um igarapé que se chama maupaariu; Eles entraram garimpeiro aí fizeram pista depois começaram garimpar e sujou nosso rio único que passa no toototopi nesse tempo eu estava lutando e aí eu fiquei preocupado porque eles estavam pegando peixe bêbado na água contaminada pelo mercúrio garimpeiro usa mercúrio mata peixe e nós estava lá embaixo. Eu não gostei rio sujo eu lembrei por mim, agora eu sou um rapazinho já sei que não quero acontecer morrer outra vez por causa de garimpo como aconteceu na chegada na comissão de limites no Marakanã agora eu sou rapaz, estou lutando eu falei para os patapata é melhor sair daqui para outro rio: pra Demini. vocês Demini theri pode mudar.

Aí eu falei também com Fialho e finado meu tio (...) ele foi pro Kokoiu e ele entendeu: 'tá bom vou ficar, lá o rio tá sujo realmente [para] nossa sobrevivência, melhor mudar'. O rio estava assim amarelado. Aí eu falei com Luixi, Roque eu disse: vcs vão ficar no Piau, no verão o Piau é pequeno mas depois ele fica cheio .

Aconteceu isso essa minha preocupação, não é dele não.

Eu não gostava também que missionario proibia xamanismo por que o costume é nosso: quando eu era pequeno eu ficava caladinho quando eu cresci eu falei "vcs querem ajudar ajude a nós vcs ficam proibindo xapiri, é costume nosso", aí eles respeitaram o meu xoapë (tio, sogro) finado. Eles foram lá pro Novo Demini então nós vamos mudar pra lá vcs mudam pra Novo Demini lá tem peixe não tem garimpo. Fizeram casa lá, fizeram roçado lá. Aí os missionários não quis ficar sozinho aí foram atrás deles.

(Depoimento de Davi Kopenawa, 31 de outubro de 2017, em Florianópolis)

Observando registros da história de ocupação, povoamento e mobilidade do Toototopi (NILSSON; FEARNSIDE, 2011) em 21 anos eles mudaram de casa várias vezes, se dividindo e se juntando. Esse conjunto de pontos são sítios ainda hoje visitados. O arranjo histórico atual se reproduz no passado havendo uma política territorial em relação aos outros (napëpë). Em 1991, um grupo grande dos habitantes mais próximos do posto se deslocou, convidados por Davi Kopenawa na época; a Missão Novas Tribos do Brasil, New Tribes Mission acabou por acompanha-los. Esse grupo passou a habitar as margens do Rio Demini, passando a denominar-se "Novo Demini". Note aqui a importância no depoimento de Davi para o protagonismo dos habitantes do Toototopi, os Hawarihi theri (povo da castanheira, atuais Novo Demini) ao afirmar a iniciativa de terem eles se mudado e apenas após, a missão te-los seguido.

Os habitantes do Piau mudaram-se do Rapahiki após se separarem dos hoje habitantes do Apiahiki ainda no ano de 1994, quando também deixaram de morar no rio principal da região, o Wayahanau (Rio Toototopi). O surto garimpeiro e suas consequências sanitárias e ambientais obrigaram ao afastamento da calha principal da Bacia do Tootototopi de outros grupos, como os Wetehei, próximo do Rapahiki e os atuais Maraxipora, próximo da missão (originando o Kokoiu) e do Wanapiu, habitantes de próximo da missão. É dessa época o maior surto de malária dessa região. 
Em 2003, o Kokoiu já havia sido abandonado (enquanto moradia), pela escassez de água no período das secas, tentou-se inclusive a perfuração de poço sem sucesso. Os ex Kokoi u theripë se dividiram em um conjunto de casas, dentre elas, duas próximas ao posto (Rasasi e Kaxitao, menos de uma hora, permitindo a volta no mesmo dia.). Os Maraxipora já estavam separados do Kokoiu muito antes. Antigos residentes das proximidades da missão evangélica, do outro lado do rio (bem onde fizeram a casa do Piau), os Maraxipora mantinham a memória dessa convivência. Utilizavam também o Kokoiu como segunda residência e próximo do ano 2000, quando as novas roças já estavam produzindo, construíram a casa no baixo Waiahanau, na chamada Cachoeira do Cojubim (Maraxipora).

Junto à sua reafirmação como grupo distinto em relação ao Kokoiu, a mudança para rio abaixo tinha um objetivo relacionado ao comércio com os não yanomami, descendo a última corredeira maior do Rio Toototopi, estão já a pouco caminho da desembocadura do Toototopi no Rio Demini, a três ou quatro dias de Barcelos. Em 2004 já possuíam um galpão e uma casa de farinha, para produção e venda na cidade; a primeira empreitada no entanto, levou a uma decepção, pois o apurado com a venda das sacas de farinha mal pagou a viagem, na verdade, tendo o preposto da Funai ajudado com a gasolina da volta. Essa ilusão do comércio de produtos pouco ou nada processados são uma reprodução da lógica do Brasil colônia, e não tem resistido muito à experiência real do comércio na cidade.

No entanto, esse é o movimento incentivado pelos aliados da missão Novas Tribos, hoje residindo em um sítio próximo a Barcelos. Parte dos habitantes do Novo Demini desceram um pouco mais o Rio Demini, formando o Xihopi (local com muita formiga tucandeira xiho), já com pista de pouso e estrutura invejável. Tal movimento trouxe na esteira outros grupos, como o Geraldo, que havia mudado com a família para um afluente da margem direita do Demini, formando o Maxakapi; ali recentemente mudaram-se os remanescentes do Rasasi, após uma briga. E também na foz do Mapulau encontra-se alguns remanescentes do Demini, atual residência de Davi Kopenawa, incluindo aí seu filho Dario Kopenawa (atual diretor da Hutukara Associação Yanomami), junto com seu sogro e família.

Os grupos que habitavam o Paxotou não precisaram se deslocar pela perda de qualidade da água diretamente pela presença do garimpo em 1993. O Paxotou desagua próximo ao Rapahiki sítio outrora compartilhado por alguns grupos populacionais, correspondendo ao Kokoiu, Apiahiki/Sinatha, Piau. A maioria das movimentações estão associadas a óbitos de 
lideranças importantes. Embora o Paxotou não tenha sido afetado como foi o Wayahanau, os Warëpiu thëripë sempre se ressentiram do fato de os missionários não se deslocarem muito pela região, restringindo sua ação ao posto; com isso, não prestavam assistência à saúde a essas comunidades, frequentemente acometidas por enfermidades. Vieram a morar exatamente na outra margem onde há a confluência com as águas afetadas no garimpo. Ali conheci em 2001 duas pequenas casas, poucas famílias, o Koyopi e o Okarasipi O movimento acompanhou o Paxotou (conhecido como Cunha Villar, em homenagem a um militar que contraiu doença tropical na região) e hoje habitam próximo ao Warëpiu, dentre os dois cursos principais da bacia do Toototopi, tendo se movimentado para lá novamente por causa de um óbito de liderança. Óbitos também foram a causa de mudança para o Kokoiu, antes no Rio Piau e antes ainda, no Pookoxipi, onde permaneceram menos de um ano, em função de um óbito de um xapiri. Esses fatos corroboram a tese de Albert (1985) sobre o espaço político Yanomami. Está na concepção de doença e morte a motivação principal das ações Yanomami. O fato de tudo relacionado ao morto precisar ser destruido para não haver nada dele na memória do grupo, põe em destruição a própria residência e local de moradia, trocado por outro.

\section{A segunda residência na experiência Yanomami}

Pratica-se a segunda residência muito tempo antes a essa reunião, como um processo transitório de troca de casas, ou como residência alternativa deliberada, em que as especulações sobre iniciar um novo ponto de ocupação na floresta, podem resultar na ocupação simultânea de mais de um lugar. Algumas casas que agregam populações maiores, muitas vezes certos grupos familiares internos se destacam construindo um conjunto novo de roça, residência ou apenas um acampamento de waimì huu que se torna mais frequente. Está associado à escolha que certos lugares gozam como privilegiados e específicos em relação a outros. Um que havemos de abordar futuramente são as capoeiras, as regenerações de roças antigas, por formarem um sistema único, com sua história e com a espontaneidade de processos regeneracionais, numa quase resposta aos distúrbios provocados a muito tempo, seguido de seu enriquecimento com espécies pioneiras, seleção das pré-existentes, e manejo durante os anos sequentes. E aquilo que chamamos 'abandono' está longe de ter o significado atribuído segundo nossos parâmetros: primeiro, pelo interesse geopolítico de lhes ocupar a terra, esse conceito do abandono pareceria pertinente à mentalidade colonizadora. Segundo, ele de fato não corresponde ao que se sucede: em vários casos períodos de até vinte anos foram detectados até que a área voltasse a ter um uso mais frequente. Como isso se dá, sem 
que seja apropriado por um grupo vizinho e isso cause litígio, parece evidente: há um respeito e reconhecimento intrínseco da territorialidade do outro, cujos kanasipë (no sentido de obra, de resultado do trabalho de..., mas também resquícios, restos, evidências dessa ocupação) poderiam ser ocupados por outrem mediante consentimentos. Observei, por ocasião de um henimou (grande caçada que antecede o cerimonial do reahu, em homenagem a um morto), que Toto e o grupo do Apiahiki havia concedido aos caçadores do Koyopi, grupo vizinho, de realizarem a caçada na região do Maupaariu, de alguma forma ligada à memória histórica do Apiahiki; a área está em regeneração, desde o fim das incursões garimpeiras no Toototopi. É uma área similar a uma roça velha (hutu wãropata), com áreas em regeneração; sua escolha enquanto local privilegiado de atração de caça corrobora a nossa suspeita de serem lugares diferenciados. Por isso mesmo, estão inseridos em um estatuto de territorialidade, relacionada a um ou mais grupos.

A obra de uma capoeira parece ter valor similar à de uma roça propriamente. Ter ali o resultado do trabalho de um grupo, com sua história depositada, merece ser respeitado pelos outros. E cultivado pelo grupo, que ali permanece utilizando. No meu tempo de trabalho, testemunhei a dissolução do Kokoiu, que por sua vez já havia migrado da beira do Piau, lugar que abandonaram pelo Kokoiu. No Kokoiu a falta de água parece ter sido determinante para seu fim; anos depois, quando a população já havia formado as comunidades do Rasasi, Kaxitao e Maraxipora (cujos principais pata thëpë possuem origens diferentes), eu presenciei revisitas para coleta de mamão rokoari (Carica papaya), rihuari moku, uma caricácea (Jacaratia digitata, jacaratiá) de onde se retira uma apreciada lagarta de besouro do caule, dentre outros produtos. Há uma continuidade de uso do sítio antigo, nesse caso, pelos seus exresidentes.

O fato de hoje o grupo do Apiahiki retornar rio acima, tendo como pouso secundário o Sinatha (pehethëha) e recriar o Marakana, próximo à foz do Maupaariu reafirma uma movimentação retromigratória, quase pendular, de reocupação de adjacências de locais já previamente utilizados, alterados por uma ação pretérita, ao que parece valorizada como residência potencial. A segunda residência pode marcar uma memória territorial para o grupo, motivo de ponderação ao demandar o futuro sítio de moradia.

A lógica de pousos secundários, ora mais frequentes e mais trabalhados, advém da possibilidade de usufruir melhor uma região florestal maior através da rede de trilhas deles 
derivadas (ALBERT; LE TOURNEAU, 2007). Concomitantemente, podemos identificar motivação social na intencionalidade da mudança, e de servir de alternativa de fuga a algum constrangimento que venha a surgir no local atual de moradia; vale considerar que a experiência xamânica na vida da comunidade é algo bastante presente e tem por objetivo uma espécie de "manejo do mundo", de negociação cosmopolítica (TAYLOR, 1996) sempre carregada de transformações potenciais aos quais é necessário intervir. Desta forma, a mobilidade implica uma possibilidade em vista, como se o habitar não fosse na verdade o núcleo onde se mora, mas toda uma constelação florestal por onde faz sua trajetória, visto em perspectiva histórica.

Se as segundas residências são estratégia corrente e anterior ao acordo territorial aqui relatado, a novidade aqui fica pela reflexão em relação ao posto e a essa necessidade de mediar a proximidade dos napëpë como questão de equidade mínima dentre os grupos que compartilham a região, entrecruzada pelas trilhas e pontos de moradia, aos quais não houve impeditivos para a reocupação de um sítio por um grupo distinto daquele que o ocupara anteriomente; como vimos por várias vezes, tal como a segunda residência do Piau, próxima ao posto está sobre as antigas clareiras do grupo que hoje habita o Maraxipora. E se os grupos gravitavam muito mais próximos da antiga missão, a maioria ocupando terras a um raio de cinco quilômetros de distânca, hoje estão mais espalhados de determinam as proximidades da missão como território de usufruto comum. $\mathrm{O}$ afastamento deliberado da comunidades de próximo do posto parece corresponder a um menor encantamento pelo que os estrangeiros podem proporcionar, pois vêm carregados de outros problemas e sua necessária mediação política.

\section{Sinatha e Xiroxiropii}

Descrevo aqui dois exemplos de uso de segundas residências nos processos de mobilidade no Toototopi. onde discuto as evidências de as novas ocupações serem feitas nas adjacências das "hutu wãro pata" ("roça homem velho"), as antigas regenerações advindas de roças e moradas antigas. esses dois vales definem pontos antigos de passagem onde os Yanomami desceram a serra nessa região para se instalar no Toototopi. São sítios nas maiores distâncias do posto; ao seu norte imediato estão as serras a separar das cabeceiras do Orinoco na Venezuela.

Hoje habitando regiões distintas do Toototopi, os Apiahiki e Piau theri são antigos 
Sinatha theri. Enquanto o Apiahiki situa-se à beira do Rio Waiahanau (o Toototopi) a montante do Posto e antiga missão, o Piau era uma das comunidades mais distantes, e concentrava maior população (tinha 89 pessoas quando no Apiahiki tinha 55) e boa parte das memorias vivas da velha comunidade, anciãos mais velhos, exceto o próprio Totô e alguns outros que permaneceram no Apiahiki. Ambas as clareiras demonstram um tempo de permanência razoável, mas com possibilidades de ausentarem-se dos lugares principais de moradia, ou seja, utilizando-se de outras residências alternativas. O Piau hoje possui pista e constitui um subpólo do Toototopi, com mais de 100 habitantes, uma tendência a permanecerem mais tempo no local, apesar das condições de distância da calha principal, em um pequeno curso de água intermitente; nos tempos de seca mais acentuados, em geral em janeiro e fevereiro o igarapé seca e é necessário cavar cacimbas no seu leito.

Nos relatórios e em textos sobre a região do Toototopi eu havia lido sobre os antigos Sinatha theri e tive muita curiosidade sobre onde seria esse lugar, Sinatha, onde os Yanomami com quem eu convivia haviam morado, ao ponto de o povo ainda hoje se autoidentificar Sinatha theri, povo do Sinatha. Eu consultava sobre como seria esse lugar, com meus anfitriões. Numa dessas conversas, Totô anunciou seu plano de me levar a conhecer, estávamos no Koyopi, uma pequena casa no Paxotou, participando de uma festa de beber mingau de banana koraha $u$, sem maiores cerimônias, um reahumoupuo ${ }^{30}$.

Toto, Kurika e Adilson me levaram, utilizando como abrigo a casa nova do povo do Apiahiki, Sinatha pëhethëhami, uma yano (residência circular, roundhouse) de telhado único (uma água, vertendo para fora do círculo). De lá saímos em direção à serra onde fica a antiga moradia Sinatha e hutuwãropata chegamos subindo pelo curso dágua, em rochas do cristalino e encachoeirado. Num dado ponto, Toto observa uma água rasa, e afirma que está uxixi (remexido, turvo). para mim estava igual. e que aquilo era obra de queixadas... Pouco acima, encontramos a parte do curso dágua (Sinatha $u$ ) que participava da vida cotidiana dos Sinatha: o local de banho, local de coletar água, e enfim, a própria localidade da yano, identificada pelas árvores à volta e dentro de onde ela esteve, no passado, hoje há um ingá sp. krepu uhi, com DAP $>1 \mathrm{~m}$. pouco adiante mostrou-me árvores mais antigas que existiam na borda da roça, visível da yano.

30 Reahu é o nome dado à principal cerimônia relacionada a um óbito; quando se consomem as cinzas mortuárias oferecidas com mingau de banana korahau; mas é possível o uso do termo acrescido de puo, que significa “à toa, sem razão”. Reahumupuo fazer festa a toa; beber mingau em comunhão. 


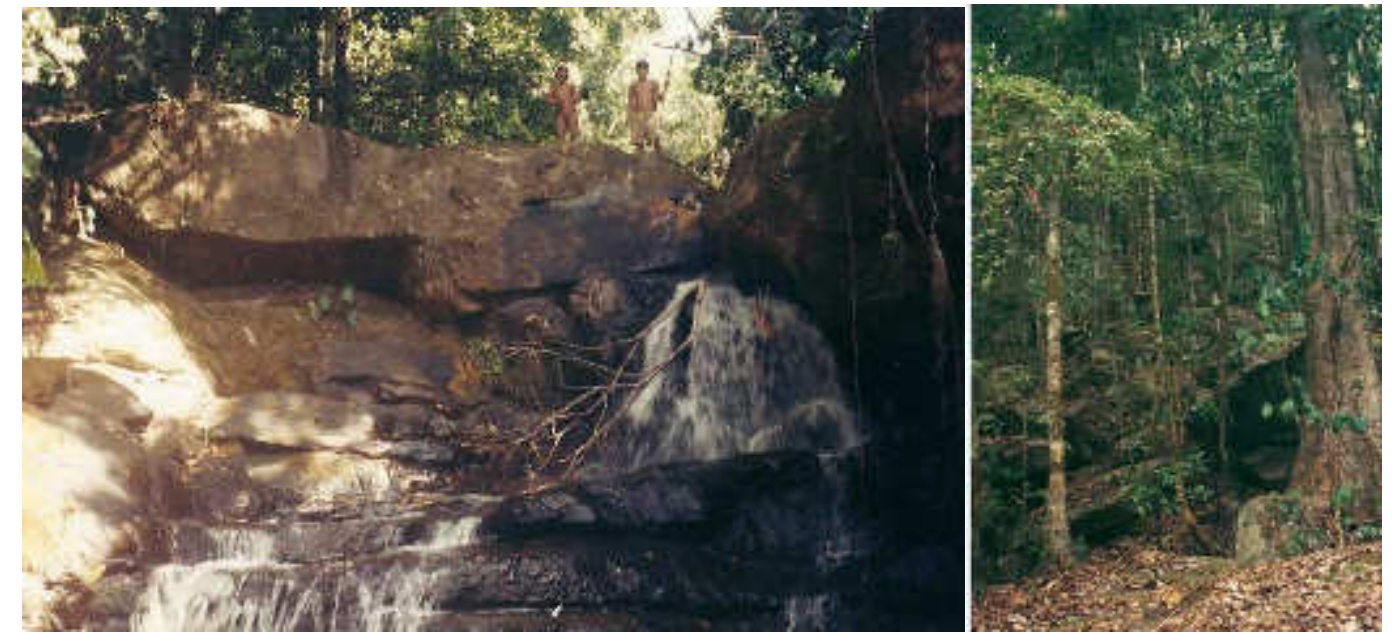

Figura 11: dois aspectos da região do Sinatha, a primeira a queda d'água logo a jusante do antigo sítio da comunidade e a segunda, a cena da entrada da comunidade pelo caminho de acesso à água.

Observando as árvores do local, não se percebe uma diferença tão grande da floresta circundante, apenas alguns pakovazais (uma musácea percebida como indicadora de onde as plantas da roça viscejam mais). E o sítio realmente indica algumas especificidades, em relação ao acesso à água, à observação de quem chega ali pela via da água, e uma certa área de solos de sopé em uma região predominantemente serrana e rochosa. Naquele dia, o professor Adilson, originário do Hwaximu e a muito radicado nessa comunidade caçou um queixada, espécie que vinha ficando raro àquela época e associado à invasão garimpeira. E totô contou ser ali um lugar frequente de caças fartas, de presença de animais maiores. Era um lugar saudoso do ponto de vista da alimentação. Sabe-se, essa é uma questão fundamental, como veremos nos discursos de Barbosa, liderança do Xiroxiropi, e também na literatura recente que relata a importância e o medo da fome, principalmente para os povos das serras (MARTIN, 2016).

A localidade onde era o Sinatha (local de muitas nascentes, seria uma tradução aproximada) ocupa uma pequena serra, prolongamento do maciço que se eleva ao norte do Toototopi, em direção às cabeceiras do Orinoco. Rota migratória de descida, essa localidade foi uma das mais longas ocupações, segundo os seus ex-habitantes. Davi conta em sua biografia uma festa reahu com o povo do Sinatha, e em outros momentos também. Sua importância é demonstrada também por ser o local escolhido para uma segunda residência dos Apiahiki.

Que razão os fazem hoje voltar para próximo de onde já moraram? Seria mesmo algum tipo de apego a tal lugar ou alguma outra questão invisível? num primeiro trabalho 
(NILSSON e FEARNSIDE 2011) exploramos os efeitos na floresta causados por esse tipo de migração; de forma abrangente, porém deixando os estudos de caso das mais variadas populações da TIY ainda a ser pesquisado. neste texto investigo a respeito do movimento retromigratório, explorando o caso dessas duas comunidades do Toototopi, tanto quanto a possíveis benefícios à ecologia da caça desses lugares. e concluo que as capoeiras advindas de antigas moradas, são um tipo de ecossistema específico, onde a presença humana beneficia processos de renovação da floresta, em uma escala conveniente à atração de fauna, ao aparecimento de espécies de crescimento rápido que dominam a clareira, e servem de alimento para uma determinada fauna, porque frutificam em abundância. Além da caça, com várias espécies atraídas, outras fontes alimentares aparecem, como os cogumelos, pequenos animais. Entretanto, não é possível resumir a isso a razão dessa escolha.

Há um aspecto de manejo, onde a floresta é fornecedora das farturas que tornam a vida interessante, mas também há aspectos sociais; nas viagens a essas localidades testemunha-se uma descontração maior, um riso mais fácil dos que ali se estabalecem por um tempo; Bruce Albert já havia informalmente me dito que essas ocasiões são momentos em que se descarrega um pouco as tensões relacionadas ao convívio denso na residência principal. E as modificações ambientais que se fazem nessas áreas, são muito menores que as da residência principal, com suas ampliações anuais de clareiras. Quando visitei o Sinatha, as roças ocupavam um pequeno jardim de nasisiki (Manihot esculenta), e a imagem recente parece indicar um cultivo menor ainda. As relações são em grande parte voltadas para a mata, e a um distanciamento de outros Yanomami, pois essa área está bem distante de outra comunidade.

Em 2016 para 17, uma localidade mais próxima do Sinatha tornou-se residência do grupo do Apiahiki não se sabe por quanto tempo, mas estão lá a uma temporada, com abertura de clareiras, redenominado Marakanã (nome de uma velha comunidade, citada por Davi em sua infância, onde morou junto a Toto). Um aspecto positivo para o grupo é o aumento da disponibilidade de caça, por estarem em uma situação distante; mas atribuir uma ação mecânica e determinística, pelo fato de se ter demonstrado em trabalhos a depleção local de caça sofrida por um agrupamento residente, parece um pouco precipitado. São muitas ações envolvendo a caça e objeto de profundas reflexões xamânicas (Yarori, as entidades xamânicas da fauna hoje consituinte da alimentação yanomami, são diversas e parte de uma realidade cosmopolítica complexa). E presenciei episódios sobre encontros com animais onde os Yanomami deliberadamente não caçavam. Nessa caminhada relatada aqui, Adilson, o 
professor presenciou um mutum paari ao chão, andando, e não atirou sua flecha, caminhando com naturalidade. Ao lhe perguntar, disse ser aquela uma fêmea com filhotes, ela se expõe para desviar a atenção em relação às crias. Em conversa com ecólogos, confirmaram ser esse o comportamento dessa espécie. Há uma clara intencionalidade de garantir proliferação da espécie, frente ao imediatismo da refeição.

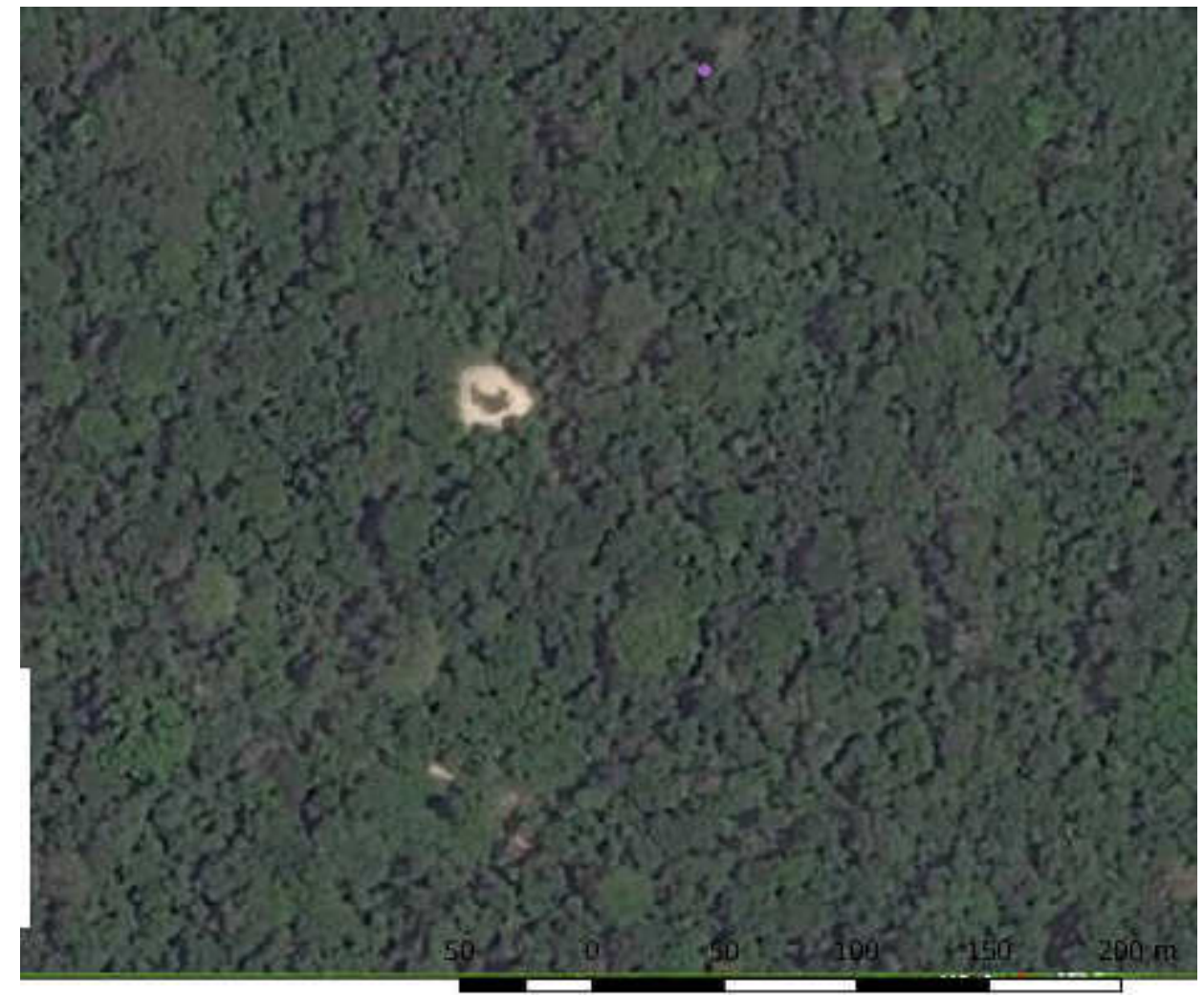

Figura 12: Sinatha, segunda residência dos Apiahiki theri, a cerca de $4 \mathrm{~km}$ da antiga moradia que os denominavam. Outrora cercado de roças, hoje encontra-se cercado de áreas regeneradas. A construção é uma habitação coletiva redonda, com palha de ubim paahanakí (Geonoma guianensis) e abertura no pátio central, e vertendo suas águas para fora.

A aparente condição de não controle, dada pela dispersão da caça na floresta pode ser uma escolha pois garante a liberdade de procriação das mais variadas espécies, diferente de nossa necessidade de controle sobre a produção, no nosso caso nitidamente associado a nós pela domesticação. Ora, a opção de não domesticar, descrita por Descola (1998) tem consonância com o pensamento xamânico. E não parece fora de controle nem entra em um registro de escassez, mas de presença na floresta, ainda que incerta e dependendo da habilidade em encontra-la.

O Xiroxiropi origina-se de uma das últimas levas de Yanomami adentrando o Brasil, sobretudo em função de alianças intercomunitárias com os grupos do Toototopi que viabilizaram o acesso à Atenção à Saúde. moraram originalmente próximos ao posto, e 
mudaram-se definitivamente para a atual posíção à época de minha chegada ao Toototopi em 2001. O grupo recebeu apoio/apoiou (de) habitantes do Toototobi que eram originários de Haximu, também na Venezuela durante suas visitas no Brasil. Desde que iniciaram morada no Brasil, fixaram-se originalmente próximo ao posto, numa clareira ainda hoje existente, tomada de um emaranhado de vegetação. A proximidade com outras comunidades (ali, a questão de uma hora, moravam mais três comunidades) levou a intrigas que os fizeram abrir novas roças no Xiroxiropi. De lá abriram uma roça de apoio no caminho para lá (Iwapi u), mas não chegaram a se mudar para lá.

A localidade de morada do Xiroxiropi está em um anfiteatro aberto na serra pelo Xiroxiropi $u$, curso d'água formador do Paxotou (Rio Cunha Vilar, na carta do IBGE/ DSG) e no sopé da serra, ainda em terreno relativamente plano. logo acima, encontram-se as primeiras quedas de água em leito rochoso. Essa localidade foi ponto de acesso de diversos grupos que hoje residem no Toototopi, desde que desceram das serras onde se encontram as cabeceiras do Orinoco, o Hara u. A clareira de roças ocupava, em 2001 estritamente a área interna ao anfiteatro, o que permitiu observar a cobertura vegetal das áreas circunvizinhas.

As áreas circunvizinhas à instalação da comunidade apresentavam algumas concentrações de espécies vegetais úteis, das quais eu destaco uma concentração de pés de cacau (porounahi), relativamente extensa. Era local onde as crianças e jovens buscavam frutos. Indicava claramente uma origem humana, tanto pelo agrupamento de espécimes, quanto pela situação, em um local com especificidades, enquanto sítio de moradia. Ali já fôra habitação de outros grupos. A escolha do local pelos Xiroxiropi theripë levou em consideração essa localidade, e a intenção de ocupa-la por um tempo mais longo.

Em um discurso noturno, Barbosa (liderança do Xiroxiropi*) afirmava a gratidão com a nova situação, ao relatar os diversos lugares que havia habitado no passado, em função de ser rechaçado por diversas vezes, pela inimizade e antipatia de outras comunidades vizinhas, pela perda de "esteios" da casa (referência a pessoas falecidas).

Disso se nota que, embora a mobilidade seja algo desejável para os Yanomami, não significa que a possibilidade de uma moradia fixa e segura não seja igualmente desejável. Tempo de permanência em um lugar é motivo também de felicidade. Não se trata de ver na mobilidade um parâmetro, mas perceber que a dinâmica de movimentações e mudanças 
residenciais entra igualmente nesse processo, se colocando como possibilidade para as ponderações do grupo, em ocasiões em que essa decisão possa ser pertinente. Reproduzo um longo trecho do depoimento por ele historiar a trajetória do atual Xiroxiropi, e se consideram Moheresipitheri.

Hapenaha... kami ya kakii hapenaha hwaya ya kuma: Kuma yaro, hwaya tirakiwi ya thëã hwai: Hapa horepëha, pata thëpë piriouwi: Yareyakapë parikiha, Ipa pëni thë taaiwi; tharani, mamoxatiopë thë taa kõoiwi, tharani, kami ya mii (...). yaretha koõtëhë...kõowi, tharani pata thëpë komi yatotoarioma. Yatotoariwi, thi tëhë, kami ya kakii thi tëhë, porapiuhami ya kõkema; patathëpë komiha nomarini, ihł tëhë hwaya yama hwarini, kihami pata thëpë pirimouwi, kami ya kakii, Porapii yaha kuikunt kami ya wawërayoma; thi tëhë kami ya wawërayuwi, ya pihi moyamirayoma; waisipë ya oxe mahioma makii ihł ya wawërayoma; ihi tëhë ya moyamirayoma ya oxe mahi makii. thi tëhë ya kõkiwi (...), hapa taarema ya thë tarini, (...) ya rama huu tamorini. ihitëhë kami yani hwaya noa xarirał xoaoma. kami yani hwaya ya noa xarirat xoama: awei, inaha thë kua noa yaro hwei urihi kakii, Kihami pata thëpë pirimouwi ya taaimaoma; maki tha ya pihi homoparini, Inaha thë kua noa yaro inaha pata thëpëni hereã thëã tanoahe.

tha ya ku xoaoma. kuma yaro, wãroho komi uku kutaopënaha ya yokit tararema. yoki napë ramahuu xoaoma. thi urihiha ya pihi ha thë kunimi; ya pihiha thë kuu kupere, thi tëhë ya patakema. tha ya patahikinit, ya pihiha kupere; morimori thë xiro, tha ya patakema; ihami ya

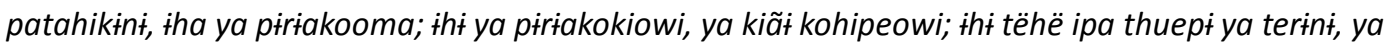
yapaakokii, okarasikateopëu ha, ya pihi yai homoparioma; ya pihiha yai homoparint, ya pihi

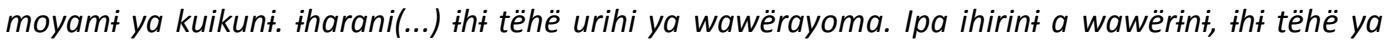
yatotoikini, Moheresipiha ya pihi patahomoparioma; kami a pihi pree pata homoparioma; tha Moheresipiha xawara yai kuakõprarini, thami, xawara yama a pree marayu, ipa xoa ya e pree marayu; kami ya kaakii hwaya marayu yami ya parini, thi tëhë waisipë ya piria, Kõoparioma. (...) xawara a yai kuakoprari ni, wayu koaiwi.. koatwi...

Quem prantou a quem plantou a ka kii: Marco. () komi patahea ximirint hwaya awei inaha thë kua noa yaro pata thëpë

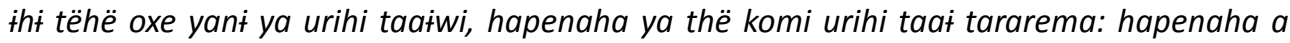
kuma, komi urihi tararema: Orapiu; usisimau; uxixiu; Taraipoko xakipiu; kasipiu; moramahiu; momihiki u; hawarikohipiu; Pahanaki u; Manakariu Poramahiukatiopëu. tha ya patarini, Poramahiukatiopëu ha, thi ya ramahuu tamoimi; tharani, ya moko kokiwi, ora prat (...) ya hapatarini, ya moko kepariowi , ya marini, (...) Ya urihi taariwi, ipa moko hwaiwi, Pihi homopu tariwi, ya Kõakokiwi, a maru. Ipa ihiru kua ya tapouwi, Ihiru kua haromai; (...)kua hirini taapetayou. Kua yaro, Kami ya yopë taai; taai yaro, Uhanapiu; Xamau kahikiu; ukahipiu; Xamaukahipiu; Torapiu, wakaraxiporomanou; Karikaripou; põyariyarimapiu, hwaya piu; iwapiu; ihi tëhë komi urihi taarema; yai pata ya nikere. taarini, hwamahuuwi thë kuparioma; oxe o tëhë, hwamahuuwi thë maoma. ai urihi taaihikioma yaro, komi ipa oxe ya thëpë ya e yemakamai, hepara Aweita ya yëmakamai, ipa tee ya yëmakamai, ipa ihiri ya yemakamat. hapenaha thë urihi kuoma noa : (...) Amahipiu, wereheu, (...) Hixiarapou; maamakioteopëu; maamapiu. tha, maamapiuha komi thëpë kãe xëyoma. thëpë xeyuwi, komi thëpë taarema (...xorieni? xori enio?) ihi tëhë, komi ya taarini, (...)ihi tëhë pata ya thëpë watu xoawi kami ya kuparioma; komi akaakii urihi komi kutarenaha(...)momihiki thëã kãe kua, Ai urihi hwetuhami: wanapiu, watuparimasikatiopëu (); tha urihi taai tararema. Thë uku pai kõowi, mahukihami paikõowi, yopë taarema. inaha urihipë kua; kuoma makure, urihi takohuruma. Hapa thë urihi taa+wi. Ya thëpë urihi takohuruma(...)

Hwei urihi kaaki, pihikuma makii,urihi tëanomi, tëanomi, ma: hwei urihi kakii ya peximaimi ya pihiku yaro heami komi thëã ya kurayoma.

hapenaha ya ukukuai, hayumaiwi uku kua: Iwapiu, Paapiu, momihiki, (...) wereopëu (...)inaha u kua. makinahipiu, inaha upë kuoma (...); inaha urihipë kuoma

ya pihi yai moyamakema; hweitëhë ya pihi yai homoparioma. hwei escola hamł a kupario tiitëhë, xori Keni ware a nakał hëami yatotoowi, ya thë urihi taarema yaro. heami ya pihihomopou, hweitëhë kami ya waroo yaro, tihuaiparioma. Kuwë yaro ipa oxe ya thëpë yemakamat. (...) ipa hwaya hayumaiwi, hapënaha mauku kuoma; Hei mau maa këpuwei (...) 
OsimaXatiopëu; Aropë napë pata u; tharani, (..)Nakaiapiuu; tharani, pahanaki u, ipa xoa e hwaya a pirikema. ihitëhë a pihi yai homoparint thi tëhë a warokema; aha waroikint, kami ya kaakii (...) kami ya wawëmarini, yahaki kuoxoaparioma: Gilvan, aweita, Adriano, malu kami ya barbosa [16:00]...

inaha yamakł kua; kua yaro, ipa urihi kua; urihi taat yapamu hapenaha thë urihi kua:

nakaiapiu; yaipuximu;puruawanou(...) koai, moramahiki; moramahiki parikiha patathëpë yai pirioma. Hapa, yano prauku patathëpë yai komi hiraainothare; (...)tharani kami ya pihiha hwant wawëmarini yaparini, ya thë urihi tararema; kihami urihipë yamaki yai pirtoma, patatëpë хё; yamaki xëparioma; thuëa noaha, yamaki xëparioma! thëpë kuuwi, ya thëpëã that. (...) kohiu; (inaha thë kuataa kura? Se pergunta) mokuramayarikiu pata thëpë warëkiki yapaiwi; pata thëpë pirimouwi, kupaiwi, napë hami huuwi; inaha thë kua yaro, ya patamou; patamou yaro ya thë urihipë kohipë toa hweitëhë; oxë mahi makii ya patamou, komi thë urihi kaki ya... ya thë urihipë kohipë toat, inaha të kua; inaha pata thëpë urihipë kua; inaha patathëpë yai taaiwi kami ya kakii, mori a patarini hea; mori a pata hëa. A pata urihi raromaiwi, thi xë oraruwi oxe ahami ipa hwaya patarima kãe kua. kua yaro komi kutarenaha, ya thë urihi taaiwi, ya hwaama huupëhami urihipë taaiwi, Manakariuhami pata thëpë hapa pirioma, Hapakaxiuha pata thëpë hapa pirioma.

Hapenaha urihi thë kua: thëpë pirikema, thëpë pirikiowi, ai thëpë Kuremiha ai thëpë piria; Komokosipiha hapa pata ipa thëpë yai pirioma; pirioma makii, hweitëhë, yanomami ipa thëpë mii: Ipa pata thëpë yai maprarioma; Kuwë yaro, Komokosipiiha pata thëpë piriowi ipa hwaya kãe piriowi yaro, yamaki komi nomarayoma yaro, ya thë kõo taimi. Taimi yaro, urihi ha xarirai; kami ya, yai pata oupetayupëha Mamoxatiopëu ha, ya pihi moyamekema; moyamekema makii, ai Yanomami waitheri mahiowi thëni, yama thë kãe horepë ya kuikint motao a kuikuni, yamaki

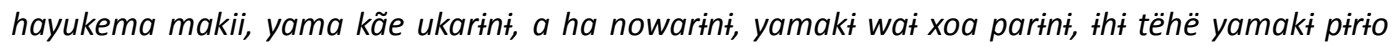
xoakema, pirio yanikini, kohipë xoakema ya thë urihi hapa taarema iht ya kohipë tararioma (...)iharani yaro ya tharema; ya thariwi, ya temi kupariowi, Ya hiriprat maraopë; xitipari maraopëha, ya pihimoyamekema. Ya kãe pikathëu kotaoma; ya yapaakokiowi, Penehe kua, ya piriakokema; Ipa thuë pi ya kuparioma; a ha kuparini, ya poma makii ... Kuakokiwi(...) Ipa ihiria $W^{*}$ a hetemou koki tha parawau kokiwi, a ximinapëowi, thi tëhë ya wawëxoarayoma. Okarasikatëopëuha ya thë yai kohipë taarema ya thë urihipë ha taarint, tharant ya pirio kõo yai kohipëxoakema; Kohipekëma makii, Waiwai a pëi kuikint, yaniki tete mahi kuoma makii, ihi tëhë waithëri ya piria kõpariowi, ya paikõpariowi, ya kokema; kua kokema; yanopëha yano kua kõikinit, xoarayoma. ai yano a that kõomai heãmi ya kurayoma ai yano ya thaikõowi thë kuaimi; ya pihikuu ha kuikini thapoma makii, thapoma makii, Kua xoarayu; Kuo xoarayoma yaro, Inaha thë urihi thathëi kua yaro, hwei thë urihi kakii, yapaaiwi thë mii. Komi kohipë kokema. Inaha thë kua. urihi ya pihi moyami hoyathikirema yaro, kua yaro Ya pihi moyami huraa hikirayoma yaro porepë ohotaai pihioimi, Urihi hoyat hikirema yaro, ya peximaimi. Ai thëpë urihi pouxoahe urihi pouwi, urihi peximaimahiowi, Urihi thapouxoahe ${ }^{31}$

31 Antes, meu pai contou, por isso, o seu trajeto eu vou contar: Antes, na serra, os velhos viviam: Na frente de Yareyakapë (baixada dos peixes 'piabas'), os meus, a avistavam e em seguida fixaram os olhos lá e [foram viver] novamente lá onde avistavam; eu ainda não existia(...) Quando voltaram a Yaretha (lugar das Baixadas) em seguida, os anciãos e lideranças todos desceram [a serra]. Tendo descido, então, eu, no Porapiu (rio com muitas cachoeiras), eu nasci; depois que os velhos já haviam morrido, meu pai me contou, sobre as moradas dos anciãos.Nasci no Porapiu e então eu passei a me esclarecer; e assim, eu me tornei sabedor, apesar de muito pequeno. Então, eu saía para caçar, eu aprendi com meu pai. Sim, por isso, essas florestas de que eu falo, onde os anciãos haviam morado, eu não havia visto; mas de lá eu fui ensinado, com os velhos relembrando desses lugares em discursos.

(...) Muitos, quase todos os caminhos existentes,(yoki = rede de trilhas) eu os vi. E ainda os caminhos para caçar. Nessa floresta eu não havia pensado, somente aos poucos, um pouco eu já havia crescido e depois de já ter crescido, ali fomos morar de novo e lá eu voltando a morar eu trabalhei fortemente, e eu tendo conhecido minha mulher, voltei lá em Okarasikatëopëu (água da palmeira inajá caída, apoiada sobre as margens), aí sim eu me tornei consciente. E sábio. E então eu abri a floresta e então eu descendo no Moheresipi, Eu então me dei conta; lá no Moheresipi voltando a haver epidemias, nós perdemos muitos, meu sogro eu perdi, meu pai eu perdi, eu seguindo em frente sozinho, mais um pouco eu permaneci morando ali de novo. Voltando de novo a ter epidemias, e então a bebida de remédio eu bebi, bebi, quem plantou esse remédio foi Marcos (huraasi); por isso os anciãos ficaram no Okarasikateopëu.

E então, ainda jovem eu conheci muitas florestas, e antes de mais nada, todas as florestas que eu conheci:Orapiu (rio de muitas cabeceiras), Usisimau , Uxixiu = água turva, remexida; Taraipoko Xakipiu ; Kasipiu = água de muitas margens; Moramahiu= árvore burserácea(Dacryodes peruviana); Momihiki u (água de muitas árvores sapotáceas momihi) Hawarikohikiu (água da castanheira dura) Pahanaki u (água da palmeira Geonoma sp. (ubim de folhas usadas para cobrir casas)) Manakariu (Awiuximou...)+ Moramahiukatiopëu (Árvore do moramahi (Dacryodes peruviana) suspenso sobre as margens) Ali eu fui crescendo, no Moramahi katiopëu. Mas até ali eu não caçava, mas então em seguida, veio a minha [filha] moça, depois de eu ter crescido, a gente subiu, com o nascimento de minha filha, enquanto eu conhecia as florestas, quando 
O discurso de Barbosa consiste em uma grande trajetória, dentre lugares onde moraram, lugares onde tentaram, onde passaram e onde visitaram. Autobiográfico, seu povo anda, luta, morre, sob a cronologia de sua própria vida, do tempo em que era criança, em que perdeu o pai, em que não possuía ainda mulher, o tempo de casado, os filhos, até chegar no Toototopi e decidirem pelo Xiroxiropi, onde estão a mais de quinze anos.

\section{Durante sua estada em outras florestas, os casos mais relatados são de conflitos, lugares}

eu retornei ela estava magra. O meu menino eu cuidei, curei o menino. Fomos indo, progressivamente conhecer lá longe, embaixo, por isso os caminhos eu conheço; pois já os vi: Uhanapiu, Xamaukahikiu, Ukahipiu, karikaripou, Torapiu, Poyariyarimapiu, Iwapiu (água do jacaré) (sequencia de nomes de locais de moradia); e então, todas as florestas nós fomos conhecer, muita variedade de tipos, olhando quando passei a sair para visitar; quando eu era jovem eu não visitava, outras florestas eu já havia olhado, por isso eu quero contar a todos os jovens eu quero contar, ao meu irmão, a minha filha, ao meu filho, todas essas florestas é que existiam: (...)Amahipiu (água onde ha muitas árvores de cerne duro amahi Elizabetha leiogyne), Wereheu (água do papagaio), (...) Maamaki (local das pedras) Arapou; Maamakioteopëu (muitas pedras caídas) Maamapiu (água do local com muitas pedras). No Maamapiu, todo mundo se bateu, e a se baterem, todos perceberam, e eu vendo todos, então eu convenci aos pata e me tornei. Todas as quais eu falo, todas as florestas, o Momihiki também, do outro lado da floresta o Wanapiu (água onde há muitos bambus wana), Watuparimasikatiopëu; ali eu descobri essa floresta. E dessas água nós voltamos, a pé nós voltamos, conhecendo os caminhos, assim temos essas florestas; mas tinhamos, pois abandonamos essas florestas. Antes, eu conhecendo essas florestas são florestas abandonadas.

Essas florestas às quais me refiro, apesar de pensar nelas, eu não me aproprio delas, não as tive, não, essas florestas de que falo eu não quero, eu penso, pois aqui, tudo eu já disse.

Portanto eu possuindo essas fontes de água, eu passo pelas águas. Iwapiu, Paapiu, Momihiki, (...) Wereopëu (...)essas são algumas águas. Makinahipiu (água onde há muitas árvores makinahi), eram águas que tínhamos. Assim, sobre essas águas que tínhamos eu me tornei consciente; hoje em me lembrei, quando na escola eu disse pela primeira vez, o meu cunhado Keni me chamou aqui em baixo, por eu ter conhecido essas florestas. Aqui, eu me lembro hoje estamos todos juntos, antes eu havia sofrido. Por isso aos meus jovens eu aconselho. Meu pai tendo passado, antes por vários rios que haviam, essa água da chuva que caiu Osimaxateopëu, Aropë Napë patau e em seguida, Nakaiapiu, e em seguida, Pahanakiu o pai do meu sogro havia morado um pouco. Por isso, eu tendo lembrado direito disso, agora nós chegamos onde estamos, e depois de alcançarmos essa ponto, eu que lhes falo, eu tendo claro, nós sobrevivemos Gilvan, Aweita, Adriano, Malu, eu, Barbosa, assim somos nós. Por nós existirmos, nossa floresta também existe. voltando a conhecer, essas são as florestas que temos: Nakaiapiu, Yaipuxiu, Puruwanou, Moramahiki; na frente do Moramahiki os anciãos realmente moraram. Antes, para uma ampla casa, os anciãos nos guiaram; em seguida, depois de eu falar e me conscientizar novamente, voltando, eu realmente descobri essa floresta; nessas florestas nós realmente moramos, junto com os anciãos, nós batemos em todos, por causa de mulheres, nós brigamos! por eles terem dito, eu os conheço. Kohiu, Mokuramayahikiu os anciãos perseguiram os porcões queixadas; foi morada dos velhos, lugar de estada, para onde se dirigiram; por isso, eu cresci, me tornei liderança; por isso, eu hoje detenho essa floresta, hoje; apesar de muito jovem eu me tornei liderança, de todas essas florestas que eu falo, eu mantenho firmemente, é assim que é. Assim é que existem as florestas dos anciãos, as florestas que os mais velhos realmente conheceram. Eu, que vos falo, um só líder sobrou; apenas um líder sobrou. O florescimento de uma grande floresta, essa também floresce quando era criança o irmão mais velho do meu pai também tem. Por isso todas as florestas que conheço eu fui visitar, para conhece-las. No Manakariu os velhos moraram, no início, no Hapakaxiu (água das panelas de barro) os velhos também moraram, antes.

Foram essas as florestas que existiam: No Pahanaki o pessoal morou por um tempo, enquanto moravam, um outro pessoal morava no Juremi; Komokosipi foi o lugar que o meu pessoal realmente morou. Mas apesar de ter morado, hoje não há ninguém lá, do meu povo. O meu povo realmente acabou ali; por isso, no Komokosipi, onde moraram o pessoal antigo, o meu pai também morou, e por a gente ter morrido todo mundo, eu não volto lá. Por recusar-me, eu retorno para a floresta: eu, firmemente cresci no Mamoxatiopëu, eu me tornei um pouco inteligente, mas haviam outros yanomami severamente bravos, nós nos tornamos pacíficos, não quisemos brigar (..). Apesar de nós termos passado, de nós termos nos retirado, ao passarmos próximos, fomos desafiados ainda,e então nós ainda moramos um pouco; morando vagarosamente, anda nos mantivemos firmemente. Foi uma floresta que conheci, essa que eu firmemente, por todos os lados, conheci. Em seguida eu atingi caça, e por ter caçado eu me tornei saudável, e mais esperto, eu também atravessei a água de volta, e voltando, havia tabaco, eu voltei a morar lá; minha mulher eu conheci, ela aparecendo, eu a tive, mas meu filho se perdeu de novo, lá no Parawau, ela estando grávida, e então eu me esclareci. Eu firmemente vi o Okarasikateopëu (a água do inaja deitado sobre as margens), e tendo conhecido essa floresta, então eu voltei a morar, ainda; me firmei ali, mas de novo vieram doenças, e paesar de ter passado muito tempo, então me tornei belicoso novamente. Eu voltei para a residência, permaneci; sobre fazer uma nova residência eu disse: não vou fazer uma casa nova. Depois de ter pensado, eu mantive e mantive essa casa, e ela perdurou, assim numa floresta madura, mas nessa floresta não voltarei. Todos firmemente concluimos essa floresta nós já jogamos fora, sabiamente, já decidi terminar, pois não quero sofrer delirando, já joguei essa floresta fora e não a quero. Outros a querem, ainda a querem muito, por isso mantém essa floresta. 
onde foram rechaçados, de epidemias e morte, de escassez, da insegurança frente a outros, antipáticos à sua proximidade, e de caçadas, de saídas para brigas. Num dado momento ressalta que aquela floresta ele não quer regressar, ele já morou lá mas já não a reconhece, pela perda de parentes. Central em motivar uma repulsa a um lugar, o óbito é o elemento marcante a definir a mudança. Não o único. Muda-se por não ser desejado, evitando esse trauma maior. Muda-se por falta de caça, de alimento, de a roça não produzir ali; mas o modo como trata a imensa lista de lugares visitados, conhecidos, participantes dessa rede de trilhas, não é de desconhecimento, mas de um conhecimento em que sua sabedoria, nascida da experienciação, aponta para as decisões a tomar, sobre ficar ou não ficar. Aponta para uma elaboração nessa decisão. Quando claramente decide não voltar a ocupar uma floresta onde já viveu por muito tempo, isso se dá pelos sinais ali presentes, pela lembrança das perdas ali vividas. Assim, como em vários momentos do discurso, afirma a reocupação de um lugar. Isso, veremos, parece ser central nas práticas dos Yanomami, as florestas conhecidas e tornadas capoeiras pelo seu uso no passado, parecem manter um atrativo de lugar diferenciado. Talvez pelo conhecimento aferido, pela familiaridade vivenciada, talvez pelas próprias condições criadas de uma história de vida ali; o viver novamente ali (piriakokiwi) é uma prática evidente em vários grupos pesquisados.

A experienciação da floresta como modo de conhece-la é deliberadamente valorizada, quando diz, em algumas passagens, 'eu fui para conhecer'. Importa aqui compreender o conhecimento da floresta não como algo dado, mas experienciado, deliberadamente, como processo de reconhecimento dos lugares por onde anda; há uma prospecção em busca das florestas possíveis para morar, onde contam as características da floresta bem como a presença ou ausência de outros moradores.

A territorialidade também está implícita nas palavras de Barbosa, quando afirma sobre as florestas dispensadas, onde já moraram e não devem retornar: quando afirma ao final do texto de outros ali morarem e apreciarem aquela floresta por eles já abandonadas, sem ressentimento e sem conflito, indica uma territorialidade delimitada no tempo, onde o abandono não resta apego ao fato de ser por outros utilizada.

Outro aspecto do discurso de Barbosa, não diretamente relacionado à mobilidade, mas não menos importante nessas questões refere-se à sua própria liderança; a perda prematura do pai resultou em sua condição de líder precoce: 'apesar de jovem tornei-me um líder' ('oxe ya 
makii ya patarayoma', na língua Yanomami sugere um paradoxo: apesar de pequeno eu virei grande'). A condição de lider, mais do que desejo do próprio e detentor de privilégios, está nessa capacidade de predizer, de decidir sobre o melhor futuro para a comunidade, diante das incertezas nas diversas alternativas de cada situação. Não a toa, a condição de realizar um hereamou, um patamou, um discurso noturno opinando sobre a situação do grupo, numa perspectiva histórica como essa, já o torna alguém com um raciocínio de líder, de uma pessoa com visão de sua história. A apresentação de tantos lugares conhecidos, de tantas moradas pretéritas é, no raciocínio exposto, um elogio à situação presente (ao tempo do discurso), em que conseguem firmar um sítio como de moradia próspera.

Desde 2001, quando os conheci, recém instalados no anfiteatro por onde o Paxothou alcança as terras baixas e colinas do Toototopi, os Xiroxiropi theri permanecem como moradores dessa mesma região, ainda agregando outro povo, os Amahipiu theri, formados pelos oriundos do Xirahi (braço da cabeceira do Harau/Orinoco) e os Hixipraopë, ambos nas serras das cabeceiras do Orinoco. Como moradores definitivos, desde 2005. Com cerca de 17 anos na mesma localidade, já com pista de pouso, a permanência num mesmo local é igualmente valorizada e desejada, o quanto haja condição para a sustentação nesse local. A quantidade de locais percorridos indica uma prospecção considerável em busca de um lugar para ficar. E novamente se aponta para o posto, para a possibilidade de acesso aos napëpë, não Yanomami, como um aspecto valorizado.

Quando em 2001 decidiram morar ali, o distanciamento do posto e das disputas e intrigas decorrentes da presença dos vários grupos pareciam motivar mais do que a presença napë; no entanto, havia a segurança de serem visitados pelas equipes de saúde (ver capítulo3). Tal distância e alheamento das disputas deram a esse grupo uma tranquilidade perceptível a quem os visitava, com suas roças extensas sobre as terras baixas do anfiteatro entre serras; e as serras à volta permaneciam como um refúgio para a caça. Por um outro lado, nunca ficaram de fora das discussões políticas da região, dispostos à participação.

Enquanto o Xiroxiropi não se mudou à época do acordo territorial, não buscou construir algum pouso próximo ao posto, havia uma certeza de manter-se sob assistência, mesmo a 22 km de distância; mantiveram por algum tempo, uma segunda residência, o Iwapiu, a apenas uma hora e meia da residência principal.. O Apiahiki, povo do Sinatha, em 2017 iniciou o processo de retorno à proximidade da serra como moradia de fato. O segundo pouso 
estabelecido no Sinatha está agora menos distante. Em ambos os casos, o que se observa, e especulo aqui a intencionalidade, é um afastamento deliberado do posto, enquanto local de disputa entre grupos aliados, porém diferenciados entre si. O distanciamento, no entanto não significa uma 'fuga ao contato', como um desejo tardio de se tornar aliado. Paradoxalmente, foi a segurança, conversada e esclarecida de estar no Brasil e assim garantir direito à atenção à saúde que lhes facultou distanciar sem perder os napëpë em suas qualidades.

As decisões políticas sobre o habitar, vistas a partir de um sujeito ou da rede de alianças e novas gentes agregadas aos primeiro habitantes do Toototopi nos remete a Ingold (2000, 2010) naquilo em que este reforça a concepção de habitar como objeto central de seu aporte teórico. E tem como imagem a 'meshwork', numa malha de relações e encontros a desenhar caminhos produzir memórias e estabelecer sentido para a existência própria dos sujeitos.

\section{Posto em reflexão, problema e oportunidade}

Cabe aqui avaliar o processo de mobilidade em resposta ao estabelecimento do posto, tentando dar conta das estratégias deliberadas e também do entendimento do posto como local diferenciado: as instalação dos napëpë, com o posto e sua pista de pouso compõem uma novidade de recursos e possibilidades em relação ao resto da floresta. Um local diferenciado e cobiçado, que não tem origem na ação de nenhuma comunidade; diferente da missão que ali se estabeleceu anos antes, a partir do encontro e acordo com um dos grupos Yanomami, que portanto se apropriavam daqueles napëpë, gerando um diferencial de poder político e acesso a utensílios cobiçados (ao mesmo tempo em que se viam pressionados a deixar práticas importantes do grupo), o posto de saúde se colocou como de acesso público e indiferenciado, sendo os napëpë disputados pelas formas de convencimento e negociação individuais dos Yanomami. Isso parece uma diferença sutil, mas implica em ter outra ética, de equidistância política e espacial, e marcar as alianças com modos mais sutis de relação, sem uma apropriação explícita.

Se num primeiro momento, o vetor de mobilidade gira em torno de estar próximo do posto, num segundo, também se faz importante estar longe, evitando assim a sorte de problemas que advém desse contato, ao mesmo tempo cobiçado e temido. O higienismo dos napëpë, as discriminações e regras excessivas, bem como os efeitos colaterais da concentração num mesmo espaço, com problemas socioterritoriais, desconfianças mútuas, e ecológicos com a diminuição da disponibilidade de caça e outros recursos, são motivos para 
esse processo de afastamento; os Yanomami parecem ter resolvido com tal estratégia, formalizada também nessa reunião, de possuir as duas residências concomitantes.

No caso dos problemas de caráter social, eu testemunhei alguns, e soube de outros: o que relato aqui, foi o estopim para a saída do povo que hoje é o Xiroxiropi de próximo do posto, nas capoeiras do caminho entre o posto e o Apiahiki. O que se conta, tanto de um lado como de outro é que as acusações de 'roubo' de mulheres pelos jovens dessa comunidade causavam discordâncias e atritos constantes. A mudança para o Xiroxiropiu, a mais de sete horas de caminhada do posto, no sopé da serra resolveu esse problema.

No caso do problema de ordem ecológica, o Toototopi convive já a algum tempo com os efeitos da instalação da missão nesse mesmo local: as capoeiras do entorno do posto somam em torno de 96 hectares, com uma recuperação lenta desde que foi aberta (antes de 1987); toda a parte entre o posto e a pista, a cerca de vinte minutos de caminhada, hoje se encontra nessas condições, pouco aproveitável para abertura de roças, sem recursos de extrativismo e afetando a fauna, em grande parte; lembro-me de um curso de formação realizado ali, em que um caçador de anta xama (Tapirus terrestris), perseguiu por dias uma anta que ali vivia, e ela era realmente pequena para o que se conhece desse animal. As hipóteses levantadas para o fato lembravam que ela já havia sido perseguida em outra ocasião e escapado, tendo sido ferida de flecha, em região não letal (a anta caçada tinha marca dessa ferida), mas contava também o fato de estar habitando um local alterado. Capoeiras costumam ser ricas em certos recursos, com maior frutificação, com espécies que não ocorrem em outros locais de florestas mais coesas, mas no caso de uma capoeira sobre-explorada como essa, poderia representar certa diferença. Toda essa argumentação objetivava explicar tal condição daquela presa. E todos tinham claro que há muito não apareciam antas tão próximas do posto, e já fazia um certo tempo o afastamento do posto como residência, desde que a missão evangélica havia mudado para o Novo Demini. As evidências indicam que a região do entorno do posto sofre de depleção de fauna, tal como indicado pela bibliografia dedicada ao tema, com métodos das ciências naturais (PERES, 2000; AQUINO; BODMER et al., 2001; JEROZOLIMSKI; PERES, 2003; BODMER; ROBINSON, 2004; PUERTAS; BODMER, 2004). A estratégia de manter residências afastadas do posto se viu acertada nos aspectos de qualidade das roças, bem como de caça, que melhora bem quando se muda para locais menos explorados. A partir dos acordos, todos passaram a ter pelo menos uma opção de pouso longe do posto, que deixou de ser um ponto de concentração populacional e cobiça (na verdade, a maioria já possuía). 
Embora a reunião pudesse ser anotada como um marco, essa ética em relação ao posto de saúde já vinha acontecendo desde a saída da missão, e ninguém se considerava "dono dos napëpë", como de alguma forma ocorria com os missionários. Os missionários tinham um grupo mais próximo e havia os periféricos, sobretudo pela posição daqueles que se mantinham próximos ao posto. O Toototopi tem uma população muito politizada, pois já experienciaram sobre (e com) os napëpë, além de possuirem Davi Kopenawa dentre os filhos dali, resultando em boas aulas sobre o mundo não Yanomami.

O acordo de 2003 se deu sob um modo de execução da atenção à saúde em que ficava clara e assegurada a presença das equipes de saúde onde quer que os Yanomami estivessem, pois essa era a política da organização responsável naquele momento, a Urihi Saúde Yanomami, trabalhando sob o conceito de assistência permanente, e não baseada exclusivamente no posto de saúde, tinha como referência fazer o atendimento nas residências, onde fossem (FRANCISCO; OLIVEIRA, 1996). Por mais de uma ocasião testemunhei a Médica Deise Alves Francisco, coordenadora da organização, pronunciar que os Yanomami poderiam se mudar para onde fosse, dentro do Brasil, que era obrigação da saúde atendê-los. A primeira vez que a ouvi, foi durante o Conselho de Saúde do ano de 2000, primeiro ano de minha experiência entre os Yanomami, e um dos primeiros conselhos a ser o mais abrangente possível. A segurança propocionada pela presença de equipe de saúde, se fazia necessária sobretudo pela experiência de constantes epidemias xawara que assolaram os Yanomami durante os anos da década de 1990. O treino de microscopistas Yanomami foi pensado para proporcionar mais segurança no trânsito entre seus diversos sítios, nem sempre acompanhados de napëpë. Assim como as escolas, que acompanham as comunidades, reservando ao posto alguma ação centralizada, curso ou treinamento com professores externos.

Em resumo, os acordos políticos entre os diversos grupos do Toototopi, dentre os mais antigos habitantes, do tempo da missão e os posteriores demonstram que a mobilidade é realizada segundo estratégias deliberadas, baseada nos diversos elementos que compõem o universo político, geográfico e cosmológico Yanomami. Nesse universo de elementos em reflexão inclui-se, certamente, a presença do outro, da alteridade, representada primeiro aqui pela sociedade de Estado, implicando numa diferenciação hierárquica de seus membros, atitude refutada pela política Yanomami. 
Do ponto de vista espacial, o Estado, a homogeneização e a formação de um poder verticalizado implica na centralidade de um lugar. Percebendo a iminência dessa centralidade na presença alienígena por diferenciar seu espaço de ocupação, o posto, essa condição é então posta em debate e são buscados dispositivos de neutraliza-lo, como outra atualização decorrente dessa mesma postura. Se podemos considerar como deliberado, fruto de reflexão na tomada de decisões, devemos ter esse entendimento para o processo geral de mobilidade, a mobilidade tem para os Yanomami uma ciência condutora; nossas informações indicam haver aí um componente de recusa a uma subsunção a uma autoridade. Incluindo aí os aspectos xamânicos e cosmológicos, a postura é muito mais de negociação entre partes.

Diferentemente da análise convencional (fatores classificados como 'ambientais', 'ecológicos' de um lado, fatores classificados como 'sociais' do outro, fruto das relações entre humanos), não há como inferir pensamento similar na análise Yanomami, rica em figuras e indiferenciações de fatores, numa complexa cosmologia que ora indiferencia humano de não humano, ora apresenta entidades sobrenaturais que temos pouco acesso ao seu universo. É mais verossímil descrever o processo a partir de uma intencionalidade onde os fatores (sociais, ambientais) estão num mesmo nível de importância, levando a uma quase indiferenciação; ambiental ou social não aparece como um dilema, podendo ser pensado muito mais como um híbrido constante (LATOUR, 1994).

A dinâmica de relações intercomunitárias, atualizada para uma situação de contato com os não Yanomami, define uma nova condição histórica para os Yanomami do Toototopi e mesmo transcendendo a região e seus grupos habitantes. O contato com o mundo do garimpo é mais nefasto e demolidor das condições sanitárias e ambientais. Isso se deu no caso do Maupaariu, obrigando as comunidades da calha principal, afetada pela poluição das cabeceiras, a mudarem-se para cursos de água menor, mas foi bem mais marcante no já emblemático caso do Hwaximu. Com o massacre, ocorrido no alto da serra num afluente do Orinoco, a maioria da população dessa comunidade se abrigou no Toototopi, inicialmente no Paxotou e depois fazendo dali o novo lar, criando alianças com várias das comunidades.

Depois do massacre e da vinda dos sobreviventes ao Toototopi, apenas um grupo retornou à beira do Orinoco (Harau). Para superar o episódio traumático, os Hwaximou integraram-se à vida do Toototopi, apoiando-se nessas alianças, e passaram a ser reconhecidos como da região. Alguns tornaram-se professores e trabalharam conosco. Um episódio recente, 
no entanto abalou a relação de aliança com um grupo, quando numa briga, fundada em acusações de furto de roças terminou com um integrante do Rasasi atacando e levando a óbito um remanescente dos Hwaximu, então residente no Wanapiu. Os habitantes do Rasasi foragiram para um afluente do Rio Demini, próximo da foz do Mapulau, o Maxakapi. Os parentes da vítima, agora, encontram-se a mais de $100 \mathrm{~km}$ de distância, e conjeturando sobre um desejo de vingança, esbarram em tal distanciamento físico. Se será efetuada a vingança ou não, está aqui conflagrada a situação dentro do modelo descrito por Albert (1985).

A experiência curta, marcada no tempo com o garimpo de Maupaariu mostrou a repulsa dos Yanomami frente à situação sanitária criada pelo garimpo: se num primeiro momento o garimpo obrigou os grupos a se movimentarem em busca de água limpa, é a postura de recusar essa convivência de exigir a expulsão dos invasores que melhor define a atuação dos Yanomami do Toototopi; tal repulsa demonstra a consciência maior de refutar mesmo o projeto de lei de mineração, figura abstrata, só possível de ser conhecida através de rede de aliados que lhes auxiliam a traduzir o mundo estranho dos napë e das sociedades de Estado. Da consciência prática dos efeitos do garimpo para sua recusa enquanto ideia, enquanto possibilidade legal a atingir sua terra e a de outros povos indígenas.

A instalação da missão e do posto criou uma condição diferenciada para a localidade, potencialmente um centro, à imagem metafórica do Estado Nacional; a atitude frente à possibilidade dessa centralidade cobiçada é o que temos a compreender dos Yanomami, postura alcançada num processo de reflexão frente ao novo, e levando a relativiza-lo, recusando sua condição de centro, para um descentramento a ter na floresta enquanto espaço amplo a definição das possibilidades múltiplas de dispersão e estruturação de redes de relações. Visto assim, o Toototopi permite observar uma rede de alianças e mesmo relações hostis mesmo com a iminência de um espaço diferenciado poder levar a uma concentração. Embora a disposição das pistas significar uma condição de novos centros, no Piau, no Xiroxiropi e no Xihopi, além das pre-existentes do Toototopi e Novo Demini, tal concentração não resiste a uma observação cotidiana, onde a floresta exerce um convite maior à dispersão e espalhamento, modo necessário de experienciação para os Yanomami, frente ao que ela oferece. Configura-se assim uma imagem que evita a centralização, revelando uma postura política onde as concentrações de poder dispersam, distribuído pelos grupos, ao compartilharem o território, estruturando a rede de trilhas intercomunitária. 


\section{Mobilidade Yanomami no Marauiá: o caminhar como 'Ethos'.}

\section{Introdução}

Esse capítulo relata e discute uma expedição na região do Marauiá, realizada com base nas pesquisas de mobilidade e as relações com habilidades de caça de seus habitantes. A preocupação central está em compreender as relações espaciais entre novas e velhas ocupações, entre relações históricas com o território e as circunstâncias da implantação do sistema de saúde, quando se estabelece de fato o contato permanente para além da Missão (restrito ao seu entorno) e do Baixo Marauiá (com acesso frequente à sede municipal de Santa Isabel do Rio Negro), estendendo-se à maioria das comunidades. Após a organização do sistema de saúde, por volta de 1996-2000, várias movimentações e novas cisões residenciais se verificaram, causando certa incompreensão, por parte das equipes de saúde, exigindo readequações nos planejamentos. O elemento principal a ser estudado e discutido aqui é uma tensão beira-centro, na linguagem regional aplicada à proximidade da calha dos rios navegáveis (beira) e os sítios remotos (centro).

Na maioria dos casos, os Yanomami habitavam locais afastados da calha navegável, tida, no passado, como uma barreira, tendo sido convencidos a se mudarem para próximo, onde poderiam ser atendidos pelas equipes de saúde. A nova configuração parecia, em 2000, ainda estável, mas foi novamente alterada por movimentações em grande parte de retomada de antigos sítios, fora do eixo navegável, no correr da primeira década do novo milênio. Mantiveram sólida relação com a floresta, mesmo adquirindo novas tecnologias, acesso a embarcações de pequeno porte e armas de fogo, utilizam grande extensão florestal, alcançada mediante dias de caminhada, eventualmente. Desenvolvem estratégias de uso territorial ainda pouco descritas; uma dessas são os pousos secundários, ou segundas residências. Embora seja provavelmente anterior à instalação dos postos de saúde, parece ter sido adaptada frente às novas relações do contato, quando os Yanomami gostariam de obter os bens e serviços da sociedade nacional (utensílios matohipë, serviços de educação e saúde etc.), sem perder as vantagens que a mobilidade territorial lhes proporciona. Alguns desses movimentos retornam ao sopé da serra, território ancestral da maioria, levando a especular sua importância enquanto local histórico. 
A relação dos Yanomami com a floresta foi discutida no passado partindo de premissas reducionistas, e relacionavam eventos ecológicos como causa primária dos deslocamentos; o escasseamento de caça em função do tempo de morada foi objeto de estudo de diversos autores, tanto em relação aos Yanomami (COLCHESTER, 1982; GOOD, 1989) quanto a outros povos (PERES, 2000; JEROZOLIMSKI; PERES, 2003).

Antes de abordar a inserção de um povo (os Yanomami) a um mundo dado (a floresta amazônica), é preciso considerar a possibilidade da interação maior produzir alterações na floresta; tal hipótese vem ganhando espaço por diversos trabalhos em que se evidenciam a participação humana na distribuição de espécies, tais como palmeiras (CLEMENT; RIVAL et al., 2009), castanhas (SCOLES; GRIBEL, 2011); também em profundas transformações em solos tropicais, uma vez antropizados são conhecidos como terra preta antropogênica (PETERSEN; NEVES et al., 2001). Outras possibilidades de interação ainda são pouco estudadas, pela complexidade implicada; as relações com conhecimentos da ecologia dos animais de caça e os possíveis manejos e práticas advindos desses conhecimentos sugerem possibilidades de pesquisa onde as relações atuais dos povos indígenas podem revelar novas interpretações para a ecologia histórica (CLEMENT; DENEVAN et al., 2015). Os Yanomami utilizam-se da mobilidade com a intencionalidade de renovação, de utilizar uma nova área territorial. Dessa forma, o dito "uso tradicional" se caracteriza menos pela imemorialidade da relação com o meio, mas pelo modo como habitam e descobrem inventivamente os novos lugares habitados.

A ciência etnográfica tem enfrentado um novo esforço de reinterpretação em seus estudos, com abordagens em que a relação com o meio, da forma como é concebida pelo povo que ali vive, nem sempre envolvem a dualidade natureza e cultura, divisão fundamental de nossa interpretação (LATOUR, 1994; DESCOLA; PALSSON, 1996), podendo mesmo empregar outras formas de agência para o que consideramos natureza. As soluções propostas por diversas representações do pensamento ameríndio, mesmo com as dificuldades de compreende-lo plenamente, atribuem significância na explicação do mundo vivido, vivenciado. Esforços baseados na teoria da percepção tem sido uma das possibilidades (INGOLD, 2000) implicando em perceber uma trama na qual o modo como construímos a paisagem também nos molda, concomintantemente (INGOLD, 2004). Numa abordagem baseada no desenvolvimento de habilidades em lidar e perceber o meio, os caçadores devem perceber sinais tênues aos quais não estamos treinados a priori, e o desenvolvimento de tais 
habilidades, embora complexos e detalhados, nem sempre passam por um registro e uma codificação precisa. Quando observamos a anatomia e o posicionamento dos Yanomami na floresta, e como identificam qual espécie está presente logo à frente antes mesmo que detectemos qualquer sinal ou vestígio, significa que não apenas a observação, mas o olfato, a audição estão integrados para tal percepção. Isso se faz essencial, pois animais diferentes implicam em estratégias diferentes de abate, variando desde a ponta da flecha até o modo como se fará o cercamento ou a aproximação.

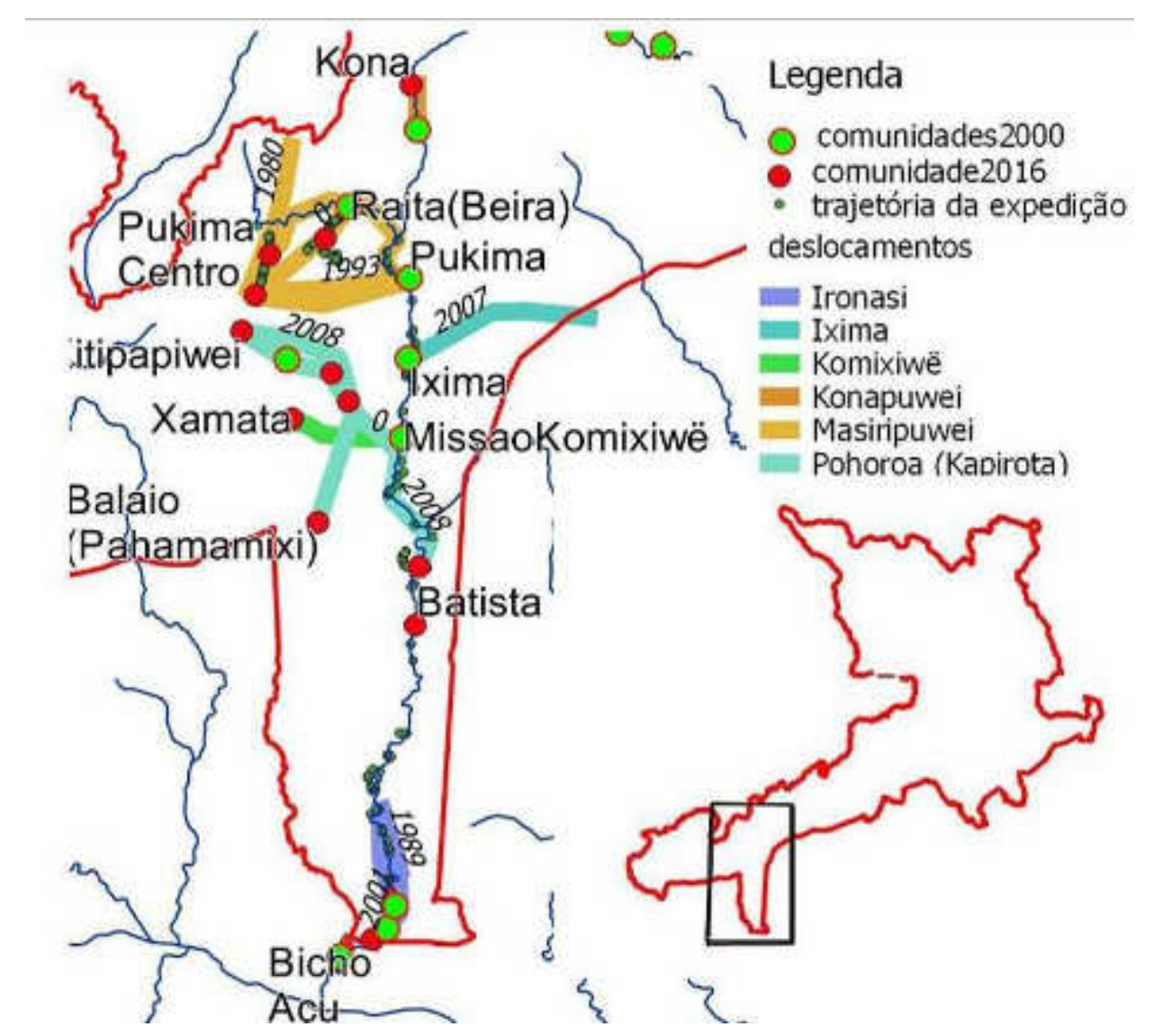
trajetórias.

Figura 13: Marauiá movimento dos principais grupos habitantes, Os anos de deslocamento acompanham as

O Rio Marauiá é um afluente da margem norte do Rio Negro, no médio curso, escoa águas da serra do Imeri (nas franjas do sul dos Maciços Parima e Neblina) e desagua já no hemisfério sul. Suas águas são classificadas como "brancas" segundo a população regional e Sioli (1991). A presença dos Yanomami é registrada pelo menos desde o início do século passado. O contato permanente se deu através, principalmente, da missão religiosa que se instalou em seu médio curso em 1962 (LAUDATO, 1998). As atuais comunidades possuem históricos diferentes quanto à localização de suas habitações, uso ou não de pousos secundários e população residente. Parte disso será relatado aqui, a partir dos depoimentos 
históricos ouvidos. O mapa da Figura 13 apresenta movimentos dos grupos habitantes.

O trabalho de campo foi realizado no período entre 11 de fevereiro a $1^{\circ}$ de março de 2009; percorremos o Rio Marauiá e afluente de cabeceira, e nos detivemos mais em quatro comunidades: Bicho Açu, Tabuleiro, Raita e Yariwei. Foram percorridas trilhas e anotadas informações dos acompanhantes. Relatos a respeito de caçadas pretéritas, e as caçadas atuais foram colhidos nos percursos de trilha, Foram treinados dois agentes agroflorestais a operarem GPS em caminhos habituais, anotar locais de caçada. Seis aparelhos receptores GPS Garmin, modelos similares, alta sensibilidade para coleta de pontos na floresta.

Os resultados do estudo evidenciam habilidades na percepção e nas estratégias de caça, destacam a produção do espaço, relatando alguns meios em espaços novos, ainda por explorar e abrir e espaços territoriais antigos, já conhecidos e retomando-os para o uso. Põe em questão as atividades econômicas a que são convencidos pelos interlocutores da sociedade de mercado monetário, incluindo fibras extraídas da floresta, a carvão. Para serem vendidos a baixo preço no mercado das pequenas cidades do Alto Rio Negro. Uso como critério nessa abordagem o conceito de colonialismo, e seu uso na exploração de matéria prima; viável pelo valor ínfimo atribuído ao trabalho Yanomami. Várias tentativas de inserção econômica dos Yanomami carregam um cunho colonial; principalmente quando se trata de explorar matéria prima pura e simplesmente; o caso mais clássico, em grande parte responsável por endemias tropicais foi o Padauiri, onde criou-se uma dinâmica de migrar para o Baixo Padauiri, e todos agrupados, colherem piaçava por uma temporada; essa condição foi propícia para uma malária endêmica, toda vez que o processo acontecia. O caso do Marauiá parece ter menor escala, mas afeta os grupos mais recém-chegados, os Konapiwei teri.

Demonstra também não haver o problema da escassez protéica tal como atribuído pelos estudos da ecologia cultural. Os motivos da mobilidade indicam ter mais relação com as questões sociais intra- e intercomunitárias, bem como o acesso à sociedade dos napëpë, que tem na navegabilidade fluvial sua via principal. Diante dessa pressão pela sedentarização, se num primeiro momento pareciam ter aceitado pacificamente a opção por instalar-se na beira do rio, mantiveram porém a estrutura de dupla residência como alternativa, e a mobilidade permanece pelas trilhas da floresta, onde exercem suas habilidades de percepção e atividades. 


\section{Relato do trabalho de campo}

Nesse relato será narrado o trabalho realizado e os dados coletados. Ao final, serão apresentados os "croquis", os mapas com as rotas de todas as trilhas percorridas pela equipe. A equipe saiu de Santa Isabel do Rio Negro no dia 11 de fevereiro numa voadeira. Iniciamos com um motor de maior potência, $25 \mathrm{cc}$, trocado por um de menor para adentrar rios menores $(15 \mathrm{cc})$.

\section{Bicho Açu}

No Bicho Açu, o Agente Agroflorestal Sabá foi treinado no manuseio do GPS e acompanhou parte do trabalho. Sabá mostrou-se envolvido e hábil, tendo aprendido a esperar a procura de satélites, quando o GPS consegue aferir a localização inicial, a observar o mapa e finalmente a marcar posições, nominando os pontos conforme seu interesse. Também atribuiu símbolos convencionados. Sabá, reconhecidamente bom caçador, se propôs a mostrar locais onde sai para caçar, navegando rio acima até o Irapajé, antigo local de moradia (em 2000, estavam com essa casa ainda ativa) de onde sai para as trilhas. O local está mais distante da aglomeração humana, deve possuir mais caça.

O Bicho Açu é a comunidade com mais contato com a cidade de Santa Isabel, pois está a apenas duas horas de voadeira. Atraídos pelo que o mundo não indígena pode oferecer de produtos industrializados, chegaram a morar durante um período de alguns meses (desde novembro de 2008) numa ilha, numa comunidade ribeirinha do Rio Negro. A história dos Ironasi teripë remonta a descida do rio nessa busca do contato, das ferramentas que os Yanomami precisavam. Renato, liderança do grupo, conta de relações com alguns comerciantes da cidade, com sitiantes para quem alguns já trabalharam no passado. O local onde habitam hoje está nos limites da terra, e foi um local de contato, de trocas comerciais. Junto à comunidade está o posto da Funai, o posto de saúde e a escola. Os professores Yanomami mantém as aulas em Yanomami; mas há forte pressão da língua portuguesa, uma vez que a relação com a cidade é feita em português. No passado recente habitaram várias localidades do Rio Marauiá acima, dentre eles Irapajé, Bicho Mirim (2000) Apuí, Coatá (1989) e, embora estando na posição atual a algum tempo, veremos que esses lugares permanecem sendo visitados pelos Ironasi teripë. A figura 14 indica a trajetória desse grupo em tempos recentes, tendo ocupado vários sítios, todos na beira. Atualmente residem na conjunção extrema do rio e os limites da terra. 


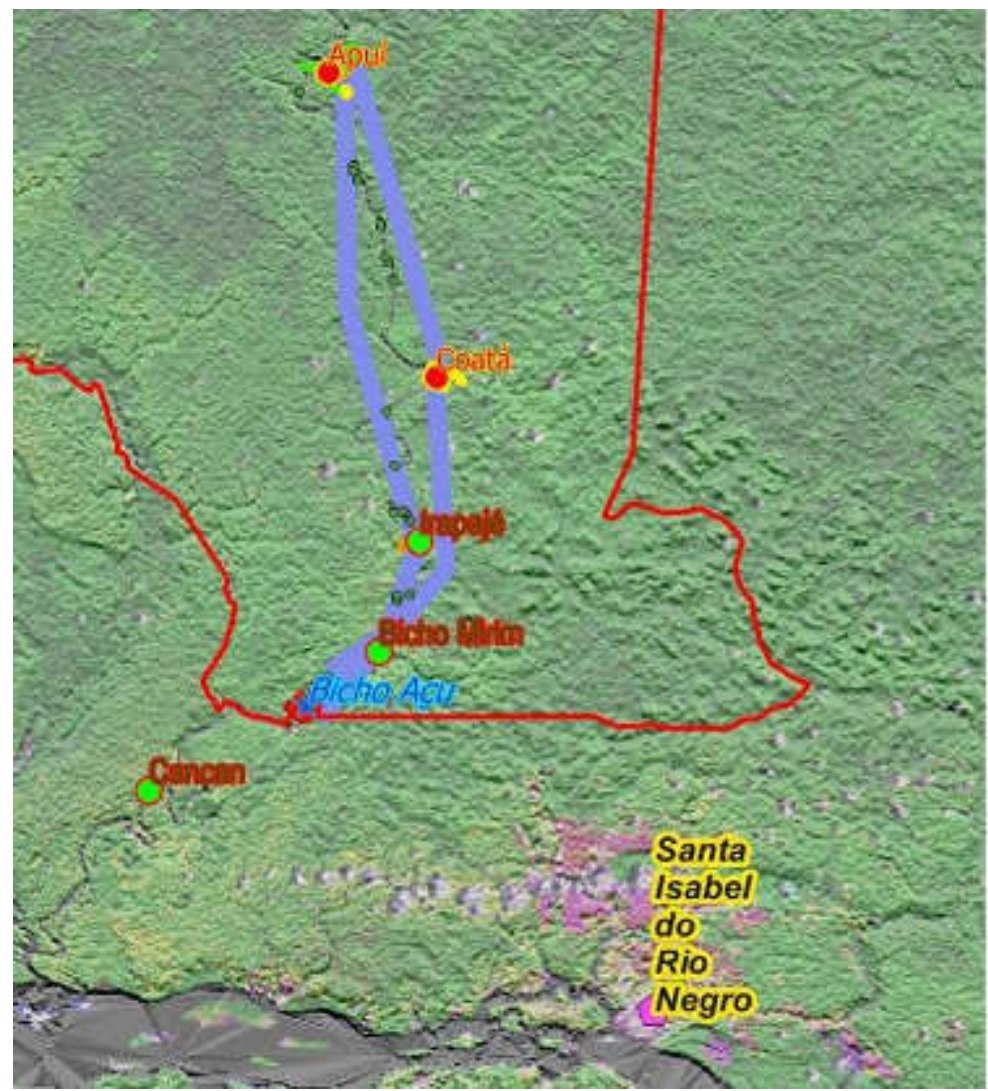

\section{Legenda}

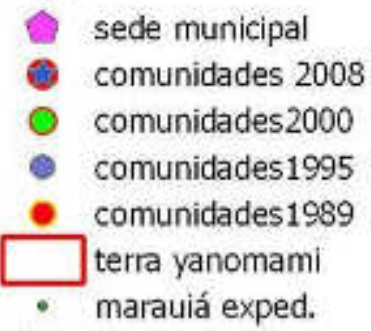

Figura 14: Rio Marauiá mostrando as moradas do povo Ironasi teripë; ao sul da imagem, o Rio Negro, e a cidade de Santa Isabel da do Rio Negro, demonstrando o quão próximo da morada atual, Bicho Açu.

Sabá escolheu a trilha que terminava numa pequena lagoa na floresta, na caminhada com uso do GPS. Averiguando posteriormente os pontos, essa localização está na divisa ou já do lado de fora da Terra Yanomami. O objetivo dele foi mostrar que, residindo próximo aos limites da terra indígena (menos de uma hora de caminhada), os Ironasi teri vivem um constante risco de invasão e efeitos da pressão por caça e recursos de seus vizinhos. Sozinho, Sabá coletou pontos da região do Irapajé, onde moraram anteriormente, uma área privilegiada de caça.

\section{Tabuleiro}

Rio acima, três cachoeiras nos separam de todas as outras comunidades, já no hemisfério norte (Bicho Açu é a única comunidade Yanomami no hemisfério sul), pernoitamos em Baraturi; um pequeno pouso à beira de um afluente de águas negras do Rio Marauiá. Cardumes de peixes se aproveitavam do encontro de águas, provavelmente com algum recurso alimentício. De manhã recebemos a visita de jovens pescadores do Tabuleiro, nosso próximo destino. Eles justamente pescaram grande quantidade de peixes (maroha), aracus (Leporinus Friderici), no caso. 


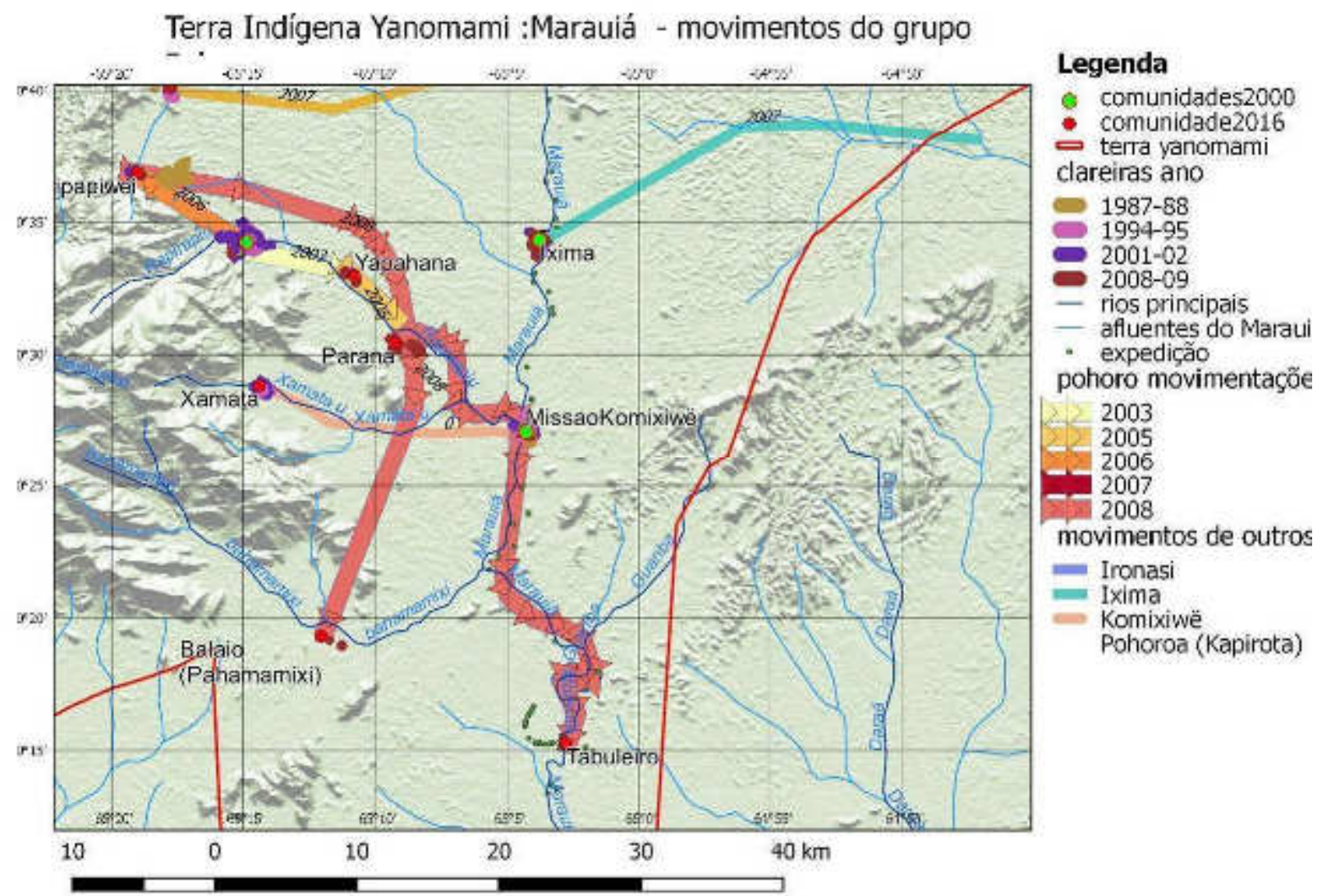

Figura 15 Terra Indígena Yanomami rotas e movimentos no tempo do grupo Pohoroa; aí se registram algumas separações e movimento pendular de Xitipapuei e Pohoro

A comunidade do Tabuleiro é um desmembramento do Pohoroa, que no início desse milênio foi a mais populosa da Terra Yanomami, com mais de 500 pessoas. O mapa da figura 15 apresenta as trajetórias resultantes do decentramento do Pohoro a, inclusive a do Tabuleiro. Dentre 2003 e 2008, originariamente no Pohoro, surgem seis novos sítios com outras roças. Foi a comunidade que mais se distanciou, mais de $48 \mathrm{~km}$, na direção sul, rio abaixo.

Segundo conversas com a atual principal liderança (përíamo), do Tabuleiro, Tiago, os motivos da mudança foram desavenças e intrigas com outros moradores do Pohoroa, mas deixando claro que a região, estando muito povoada, facilitava tais desavenças. Pohoroa fica no médio curso do Rapirapi, afluente do Marauiá, que conflui com o Xamata u, ambos navegáveis. Já o Tabuleiro, ainda em moradia provisória, fica numa barranca do Marauiá. Segundo seu përiamo Tiago, adotaram um estilo de produção mais coletivo, onde não há roças individuais, e onde há caçadas e pescarias cujos produtos são igualmente coletivos (mutirão, em suas palavras). Observamos ainda caçadas familiares, também. Pouco antes da comunidade, há duas roças na beira do Marauiá de pessoas relacionadas, Eduardo, pai de Samuel, Jorge, Tiago e Lourenço, e outra de Jorge. Não há certeza se no futuro virarão moradia de algum deles. 
Durante a reunião no Tabuleiro, expliquei o trabalho em Yanomae (a língua Yanomami de leste, denominada Waika, pelos meus anfitriãos) isso me valeu o apelido Waika. Contei de meu trabalho no Toototopi e em outros lugares da TIY, e da proposta era de verificar o papel da sedentarização para a floresta, daí o interesse numa comunidade recém mudada. A fala foi retraduzida para o Yanomami (de oeste, xamatari), discutido, debatido e autorizado; designaram Nilton para aprender GPS (o Professor não podia e o agroflorestal não estava) e Patrício seria o caçador.

Seguimos para o oeste, onde cruzamos algumas vezes um igarapé de água escura, avermelhada, denominado Iyëma (algo como "cor de sangue", numa tradução livre). Com diversas observações de evidências de animais, fezes de anta, frutos mordidos e bicados por animais, a trilha, nova, ainda em abertura se apresentava farta de caça. De fato, às dez horas, identificaram um bando de quatis (Nasua nasua) yaruxe: mesmo antes de avista-los, os Yanomami já conversavam entre si que se tratava desse animal e organizavam a estratégia de caça. Os dois ajudantes se puseram a cercar o bando e leva-lo onde Patrício estava escondido com a arma. Com a estratégia de caça, de conduzir o animal para a condição de alvo, os Yanomami desenvolvem criativamente habilidades de conduzir processos no micromundo da floresta, onde não há horizontes, mas uma conjunção de seres, dos quais as árvores são os mais destacados, e isso nos produz uma experiência sensorial para vários sentidos ao mesmo tempo, por estarmos envolvidos. As habilidades espaciais Yanomami são similares em escalas diferentes, do mesmo jeito que os jovens acompanhantes do caçador cercaram um lado para levar o bando ao outro, num plano da escala da habitação, a morada yanomami é um evento para a floresta, com a algazarra das crianças, presença de gente e animais de estimação, isso tende a ser repulsivo para a caça, e impele a fauna para sentido radial contrário; um pouso de caça à frente na trilha, a uma certa distância, causará um diferencial de presença de caça. Depois disso seguimos pela trilha, atravessando varias vezes pequenos cursos de água, a chegando a uma vegetação mais aberta em solo arenoso, uma campinarana. Trata-se de uma grande área de árvores menores, mais finas e mais baixas, de solo mais arenoso, existentes em todo o sul da calha do Marauiá. A trilha termina ainda na campinarana, em um pequeno curso de água (continuação do Iyëma, acima). Normalmente, ecólogos atribuem às áreas de contato entre sistemas uma área preferencial para a presença animal, sobretudo por agregar as características dos dois sistemas. 
Os Pohoroa teri habitavam na década de 1980 as terras baixas no sopé da serra, a oeste das cabeceiras do Rapirapiu, onde está o atual Pohoroa; foi para próximo dessas clareiras antigas onde dividiram o Xitipapiwei, agregando um grande contingente; interessante notar como a escolha se deu num processo retromigratório, similar ao observado no Pukima. Porém, segundo informam, houve muitas intrigas e acabaram por se dividir novamente. A figura 15, acima, apresenta o processo de reassentamentos do grupo, cindindo em povoamentos menores. Há um sentido de atração pela calha principal, por facilidade de acesso, com as crescentes relações, mas tampouco é um movimento único; há um freio, e há movimentos de afastamento.

Concomitante à comunidade do Tabuleiro, também se mudou outros remanescentes do Xitipapiwei, e fundaram a comunidade do 'Balaio', nome de um Igarapé cuja foz é um pouco acima no Marauiá. Em Yanomami, esse igarapé se chama Pahamamixipł̇wei (pahamamixi = balaio, ou palha para fazer balaio). Ainda tentam abrir uma trilha por terra para tal comunidade, desde o Tabuleiro, pelas relações de amizade. Perguntei aos moradores do Tabuleiro se já tinham nome em Yanomami, ou se iriam se restringir à denominação napë; informaram a intenção de denominar Mrakatahupiwei, ou algo assim, pelo fato de haver uma praia no rio, à frente da comunidade, essa palavra significa areia, depósito de areia, praia. Comentei também esse dilema quanto a 'Balaio', que têm se imposto como nome para os napëpë, sem o esforço de se afirmar um nome em Yanomami.

O Tabuleiro, enquanto sítio de morada é um lugar promissor, por estar na beira do rio. Tendo eles acesso crescente a recursos financeiros, utilizam mais a via fluvial motorizada. Isso tem se ampliado nessa e em outras regiões da Terra Yanomami. Exemplo disso é o novo barco comprado para a bacia do Rio Demini. Mazurek (2000), estudando os Waimiri Atroari aponta o acesso a transporte por embarcação motorizada como uma forma de acessar maior área e mais recursos pressionando menos o entorno da comunidade. Não existem mais estudos comparando a nova opção tecnológica como melhor ou pior quanto à depleção dos recursos de caça. Mas ela implica em maior dependência de combustível. No caso dessa comunidade, parece haver uma confiança no assalariamento dos professores, irmãos da liderança, para suprir essa necessidade.

Com os caminhos em abertura, a exploração da floresta, criando caminhos poriyoyo, há um processo de conhecer o lugar: mais do que considerar uma dada floresta como 
previamente conhecida, é a prática de prospectar o meio, de conhece-lo à sua maneira, que imprime uma territorialidade, mais do que a definição de monumentos, patrimônios naturais, as localidades se produzem associadas ao seu vivenciar, sempre usando mais do que a visão. $\mathrm{Na}$ região do tabuleiro, uma especificidade notada na floresta, é a imensa área de campinarana a cercar-lhe, um ecossistema amazônico em que há uma floresta menor, mais aberta, em solos diferentes, característicos; os Yanomami referiram-se a uma floresta mais aberta. A presença dessa campinarana parece estar ligada à drenagem e dificuldade de drenagem, deixando uma camada de umidade subsuperficial (lençol freático raso, a pouca profundidade da superfície); os Yanomami usufruem do contato entre as duas formações, a floresta e a campinarana, onde diversos animais igualmente adotam uma preferência.

Missão Sagrada Família do Marauiá. Fizemos reunião para contarmos sobre o trabalho, embora a comunidade do Komixiwë (os moradores da proximidade da missão) não seja foco desse trabalho. Os atuais habitantes de próximo da missão, são os antigos Karaw $\ddot{\boldsymbol{e}}$ teri, grupo contatado na origem da missão desde 1962. Eles possuem um local de pouso secundário, o Xamata $\boldsymbol{u}$. Antiga morada e pouso alternativo, trata-se de uma região mais próxima à serra, ao oeste, e que foi muito utilizada desde 2000. Uma senhora veio me contar que iriam para lá, me convidando para conhecer o Xamata $u$, mas não foi possível nessa viagem. No mesmo mapa da Figura 15 a missão, o Komixiwë e o Xamatá aparecem, entrecruzados com as rotas migratórias do grupo do Pohoro.

No Ixima, realizamos uma reunião para discutir uma questão prática relacionada à história recente desse grupo: O Ixima teve grande importância política desde a implantação da Secoya. Esse grupo, no entanto não possui nenhum pouso alternativo. No ano de 2008 eles se esforçaram em ocupar uma nova floresta, em função de uma crise com pessoas do Bicho Açu. Eles foram para a região do Rio Preto, a leste do Rio Marauiá, e terminaram por sair dos limites da terra demarcada, ficando em contato com piaçabeiros ali residentes, vulneráveis a toda sorte de exploração, pois estavam em condição de não proprietários, de favor em terra alheia, obrigados a trabalhar e mal conseguiram juntar recursos para alcançar os objetivos de obter pertences (transporte). A reunião redundou em esclarecer as posições e opiniões emitidas em função do episódio, pois, foi a partir de uma incursão de Paulo Welker que os Ixima teri se convenceram a voltar para sua habitação atual, mas sem desistir de criar novo pouso alternativo em uma região histórica de ocupação e presença no passado. Durante a reunião houve uma discussão sobre a forma e os objetivos de uma mudança como essa: 
Carlito (përiamo, lider atual da comunidade) pontuou que não pretendiam se mudar para morar na cidade, mas para conseguir mesmo um novo pouso, e acesso a outra floresta, bem como a possibilidade de conseguir recursos dos não índios através de um outro contato. Sugeri a ele que planejasse uma nova ocupação a distância percorrível em um dia, para as cabeceiras do Rio Preto, para aí sim, alcançar posições mais distantes. Isso os tornaria menos frágeis caso precisassem voltar para o Ixima, em busca de recursos. O relatório institucional da Secoya (Serviço e Cooperação com o Povo Yanomami) de 2009 relata da seguinte forma a experiência:

famílias do Ixima resolveram investir em uma moradia alternativa, onde, segundo eles, a terra seria melhor para plantar, daria o tempo para as roças do Ixima crescerem e ficariam livres da malária do tipo falciparum. No entanto, após um ano e do retorno para o Ixima, um grupo de 96 pessoas resolveu, em meados de julho de 2009, permanecer definitivamente na comunidade ribeirinha de Águas Vivas, no rio Preto, afluente do Padauiri. Essa decisão, na opinião da Secoya, trará muitos problemas aos Iximaweteri, uma vez que todos os homens trabalham na extração da piaçaba, não dispõem de tempo para cultivar suas roças, adquirem produtos industrializados em cantinas mantidas por patrões piaçabeiros, além de estarem fora dos limites da terra indígena. ${ }^{32}$

A preocupação reside na perda da autonomia, pois o Direito do usufruto territorial não se dá fora dos limites da terra, além de se submeterem a relações exploratórias convencionais, onde interessa a mão de obra indígena, desvalorizada e em condições similares à atuação colonial, de extração de matéria prima, sem agregação alguma de valor cultural. À época da reunião, estavam empenhados em produzir farinha, em garantir a reestruturação de sua residência no Ixima, de formato circular e separada em pequenas unidades familiares. No Marauiá inteiro observa-se essa estruturação de residências familiares independentes, mas mantendo a forma circular com o pátio central xapono aberto. Atrás das casas, do lado de fora do círculo, estão plantadas as pupunheiras e outras espécies de uso. No caso do Ixima, chamou a atenção o plantio de indivíduos jovens de Pararo, espécie leguminosa (Anadenanthera $s p$. fabaceae) de cujas sementes se faz o rapé utilizado para o xaporimou (xamanismo). normalmente as sementes são coletadas de espécimes nativos encontrados na floresta; afinal, trata-se de uma árvore de crescimento lento, cuja frutificação demora alguns anos para ocorrer; o plantio denota a intenção de presença prolongada nessa localidade.

No Pukima, à beira do Rio Marauiá, havia apenas alguns jovens, pernoitaram na sala de educação. Eles mostraram a xapono circular ainda vazia, com marcas de queixadas, visitas de

32 Relatório institucional SECOYA 2009 - disponível em:

http://www.secoya.org.br/index.php?option $=$ com_rubberdoc\& $\&$ view=category\&id=33\%3Ainstitucional\& $\underline{\text { Itemid }=30}$ acesso em: 18 de agosto de 2017 
onças (havia fezes e pegadas) e o mato ocupando o centro da habitação; o porte da vegetação indicava um tempo prolongado sem ocupação, de pelo menos seis meses. Os Pukima teri estavam em sua casa no Pukima (centro) e denominam essa floresta à beira do Marauiá de Ukuxita. Trata-se de uma segunda residência, pois originalmente habitavam o Pukima, próximo à serra. Em 2007 grupo se subdividiu em Pukima e Yariwei (conhecido pela saúde como Pukima Cachoeira), e sua casa original, próxima à serra passou a ser utilizada pelos dois grupos. Hoje eles se auto denominariam Ukuxita teri. Estavam todos voltando de um reahu no Pukima. A caminhada, com toda a população, leva alguns dias.

\section{Raita}

O Pukimapiwei é um rio menor, formador do Marauiá, junto com o Kona u. Subimos para o Raita 'Beira', onde há o posto de saúde instalado. Lá, encontramos a casa quase vazia, exceto Jovino, o agente de saúde e dois outros. Fomos ao Raita (centro) conversar com a comunidade sobre o trabalho a cerca de duas horas e meia. Jovino demonstrou interesse no trabalho e no GPS; sua atuação, tendo entendido o propósito do projeto, foi crucial para a comunidade se esclarecer, concordar e a apoia-lo. Os discursos de apoio foram claros em afirmar sobre a importância do projeto. Nesse mesmo dia saimos para a primeira caminhada, com o apoio do Professor Daniel: ele se dispôs a aprender e operar o GPS. O fez com presteza durante o trabalho. A primeira caminhada registrada foi a do trajeto entre o posto, na beira, e o Raita, onde estão instalados atualmente. Segundo as informações dos comunitários, ali, por muito tempo era a morada deles, foram convencidos a se mudarem para a beira do rio a fim de terem assistência à saúde, em 1993. Com a nova residência, não abandonaram a velha casa, retomando-a como moradia principal, desde 2007. A comunidade goza de um território bastante conhecido e utilizado, sem significar escasseamento visível dos recursos, talvez por utilizarem alternadamente ambas como residência e por esse território alcançar trilhas também utilizadas por outros grupos, a uma boa distância da comunidade.

A primeira trilha seguiu ao oeste, e virou ao sul, alcançando o caminho entre o Ukuxita e o Pukima, e terminando no Xoexoeta $u$, pequeno igarapé. Com um pequeno suprimento de farinha de pupunha (a pupunha é ralada, peneirada e seca do mesmo jeito que se faz com a farinha de mandioca), há uma prática de prospecção de recursos na floresta, em que o retorno difere da ida; no caso aqui testemunhado, os Yanomami saem do Raita em direção à trilha de ligação entre o Pukima e o Ukuxita (Ukuxita këyo); saímos da trilha (paohuru) num pequeno curso d'água (Irosirukëopë), subindo uma colina até o Iwata $u$, pequeno curso por onde 
caminhamos em seu leito (era tempo de seca). Seguimos assim por duas colinas, até encontrarmos um local com evidências de uso dos Yanomami, e a seguir uma trilha reconhecida. Nesse trecho, nos alimentamos de frutos de uma sapotácea, (horoweto kiki) e voltamos pela trilha. Nesse dia, uma queixada foi caçada na trilha entre o Pukima e o Ukuxita, um pouco à frente de onde a largamos. Essa prática do paouhuruwei permite explorar locais com características diversas, tais como leitos secos dos igarapés e o que eles podem oferecer, bem como caminhar por outras trilhas e localidades, que podem conter recursos específicos. Para se orientar em situações fora de trilha, os Yanomami atentam para a direção onde vão, e sabem o percurso dos igarapés; não demora a encontrarem marcas de ocupação e uso, pouco mais a frente. Após esse momento, retorna-se por outra trilha diferente.

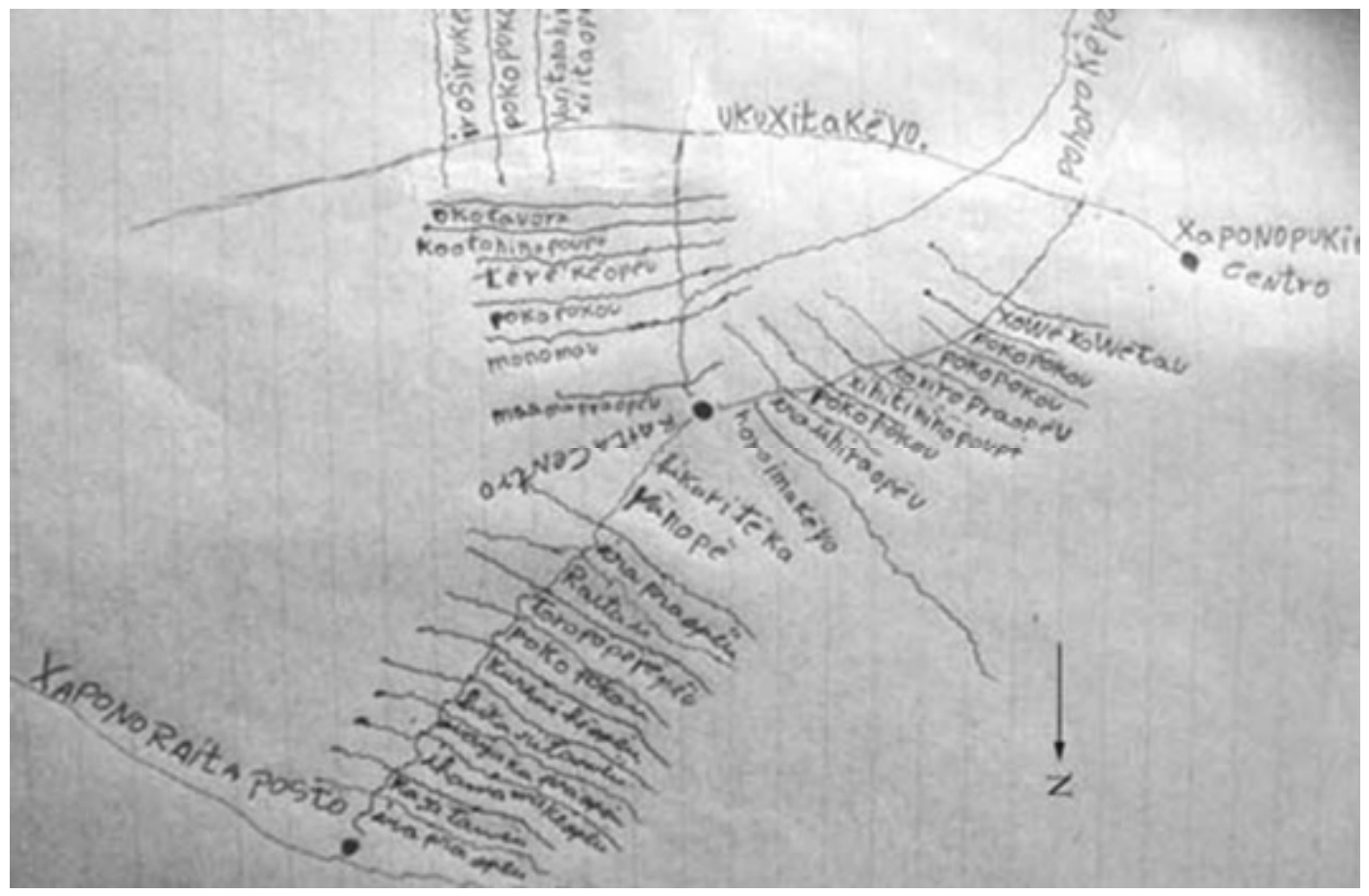

Figura 16: Fac-símile de mapa desenhado a mão por Daniel, Professor do Raita, sobre a região e os acessos utilizados para caça e procura de alimentos, sendo opções de caminhos.

Quando colocamos no mapa a rede de trilhas e veredas com leito seco de igarapés, percebemos que o paouhuruwei (ato de caminhar para além das trilhas bem definidas) permite um adensamento na exploração territorial. Daniel desenhou um croqui com auxílio de alguns moradores, com as trilhas de recursos, especialmente aquelas que acompanham cursos de água, pois além de procurarem caça, têm à disposição vários recursos aquáticos (Figura 16). Registrou-se assim, uma rede dendrítica de trilhas, com muitas opções de trajetos, devido às trilhas secundárias associadas a cursos de água cruzarem várias das trilhas radiais, interligando-as. 
Foram caminhadas seis trilhas do Raita, mais duas na região do posto e a ligação entre ambas. foram registrados algumas caças e muitos rastros identificados pelos Yanomami. Os principais vestígios de animais foram pegadas, fezes, frutos comidos e cursos de água revirados. Todos esses tipos foram notados nas trilhas, indicando a presença de antas, queixadas, tucanos, araras etc.

\section{Yariwei}

Yariwei. O canal fluvial é estreito, um pequeno braço do rio, a esquerda, com margens altas (barrancos) e bons trechos com corredeiras. Na noite anterior, obtivemos notícias sobre um menino, filho do professor que estava doente lá. A reunião mobilizou a comunidade vizinha, e fomos, mesmo sob a iminência de um óbito. O menino de fato veio a falecer, mas os Yariwei teripë pediram para ficarmos. Adriano, filho de Candinho, velha liderança que eu já conhecia de conselho de saúde em 2000, é atualmente quem representa politicamente a comunidade. Fizemos a reunião e nos dividimos em três grupos de caminhada. Segui com o agroflorestal Alberto para o Pukima (Centro), enquanto Paulo e Eder faziam trilhas em outras direções, uma para a serra, outra para o leste, a caminho do Raita e do Ukuxita. No dia 24 de fevereiro, a proposta era realizar cada um uma pequena trilha, voltando às 12 horas. Bento localizou um grupo de queixadas às dez, e caçou duas (mais um filhote), de forma que atrasamos a saída.

O Pukima, antiga residência quando esse povo, ainda uno, alcança as terras baixas, no sopé da serra de onde vieram, é exemplar para um aspecto que venho afirmando, quando os Yanomami desenvolvem um movimento pendular, de retromigração, a reocupação se dá nas adjacências da velha roça em regeneração. O mesmo desenho observado no Xitipapuwei, enquanto reocupação do velho Pohoro, antes de essa comunidade fixar-se no Rapirapiu. No Pukima, mantiveram a casa na mesma posição pre-existente em 1987; a condição de habitação coletiva xapono compartilhada entre as duas comunidades dela derivada sugere a valorização e os consensos em manterem, ambos, a espacialidade de uma floresta historicamente ocupada.

O Yariwei desmembrou-se do Pukima, vindo a habitar essa borda de serra, bem menos explorada. As razões da mudança foram explícitas quanto ao espaço de caça: se saíam para caçar, encontravam gente de outros grupos, concluindo estarem próximos demais para encontrar animais maiores. De fato, a região onde se encontram agora (desde 2007) é farta de 
caça. As trilhas estão ainda em abertura, vários caminhos são trilhados pela primeira vez. Isso significa que o mapa não contém a densidade de trilhas verificado no Raita. Seria possível encontrar uma maior densidade também no Pukima, onde já viveram por um tempo prolongado, e no Ukuxita. Ali, as informações referem-se a direções principais e alguns caminhos que os velhos conhecem. No trajeto de volta deparamos ainda com um bando de queixadas atravessando o rio, denotando a volta da abundância desses animais e a fartura de animais passíveis de caça dessa região.

\section{Discussões}

Durante todas as reuniões, a minha fala apresentava uma certa provocação: contava a eles a hipótese protéica da ecologia cultural, de que os napëpë consideram a motivação para a movimentação dos Yanomami é a falta de caça, provocada pela sua própria ocupação. Eles responderam à provocação informando não haver falta de caça para eles, passaram a enumerar a presença exuberante de caça, e que isso tinha a ver com o modo como caçavam, pois mantinham a floresta, a casa dos animais; em alguns casos reclamaram dos não Yanomami, dos garimpeiros. Nas caminhadas, demonstraram não ter dificuldade de encontrar, identificar e abater a caça necessária para eles. Embora seja essa uma hipótese já questionada por outros autores, coloca-la em questão para os Yanomami, empreende uma dupla finalidade: informar aos Yanomami o que uma parte dos napëpë atribuem como objeto de estudo (o determinismo de uma escassez protéica sobre um povo) e obter respostas da parte deles. A indignação das respostas trazem à tona a resposta de Albert (1985: 46):

(...)Nous ne nions en aucune façon l'existence de contraintes écologico-économiques complexes à l'ouvre dans les sociétés amazoniennes interfluviales, nous pensons q'elles s'exercent d'une part negativament (en définissant un ensemble de impossibilités et non de déterminismes culturels (...) et d'autre part à travers des cadres culturels (économiques, socio-politiques, symboliques) doté d'efficacité propre et qui en infléchissent constamment l'actualisation spécifique au sein de chaque société concrète.

Não se trata de negar a existência de limitações, impossibilidades, mas de perceber que soluções culturais com eficácia própria são desenvolvidas e constantemente atualizadas.

Quando os yanomami começaram a enaltecer suas obras de caça, uma ecologia da fauna apareceu, com citações dos animais caçados, e que se perseveram; afirmava como certeza, ao demonstrar a variedade de animais abatidos, garantem certa segurança, mas sugere algum mecanismo para a fauna, mesmo localmente, manter populações estáveis; isso considerando a característica da caça, incerta, dispersa... 
A existência dos pousos secundários e da utilização de mais de um sítio para alcançar recursos de caça, pela sua característica grande dispersão e mobilidade é uma ação deliberada para se relacionar com a condição imposta pela dispersão. $O$ pouso secundário parece repetir em outra escala o observado na caçada ao bando de yaruxe quatis com o cercamento deliberado conduzindo a fauna para outra posição; ele se repete na forma de um pólo expulsor e um atrator, onde se prepara a emboscada; no caso os pousos secundários tem essa característica, de se encontrar uma área renovada de vida silvestre, mas, igualmente, de se ter a comunidade habitada frequentemente como pólo expulsor e as capoeiras antigas onde estão os pousos alternativos como pólo receptor da fauna.

Os dados e descrições refletem as diferenças entre as comunidades, quanto ao tempo em que convivem com o lugar; o Raita possui uma densa malha de trilhas entrecortadas por pequenos cursos de água, ihurupë por onde se pode percorrer; por dentro dos cursos intermitentes, em seu leito tem-se um verdadeiro trajeto de passagem, sempre com possibilidades de alimentos a se coletar; diferentemente, no Tabuleiro se assiste em 2008 um processo de abertura de trilhas que ao tempo de hoje devem ter se multiplicado; testemunhar o processo em seu início de descoberta, frente a um processo de conhecimento pleno de uma dada região de uso, permite abordar e perceber as diferenças entre os momentos da ocupação.

No Bicho Açu, houve clareza de que ali próximo ao atual ponto de moradia, há uma deterioração de recursos de fauna maior em função da competição com os vizinhos não índios, que caçam nas proximidades. Seu local principal de caça no entanto, está mais acima no rio, Irapajé onde antes moraram. O uso de embarcações amplia consideravelmente o seu território de uso. Situação semelhante foi relatada para os Waimiri Atroari (MAZUREK; TEMEHE et al., 2000).

Dentre os movimentos registrados, dois demonstraram clara intencionalidade de aproximação com as sociedades de mercado, o já citado caso do Bicho Açu, e o Ixima, que retornou às cabeceiras do Rio Preto para se aproximar de grupos extrativistas além fronteiras da Terra Yanomami. Essa foi a percepção de trabalhadores na assistência aos Yanomami daquela época, e de outros Yanomami, num julgamento sobre 'virar branco'. não é desprezível a força de atração que nossa sociedade exerce, sobretudo enfeitiçados pelo acesso aos matohipë (utensílios). Mesmo o distante Kona, foram vistos descendo com grande quantidade 
de fibras vegetais do cipó titica, Heteropsis sp. (masikiki), por eles utilizadas para fazerem várias cestarias, wï pë, xotehe-...mas no caso, vendido em rolos brutos, e sem valor agregado. Incentivado por funcionários da Funai, numa visão integracionista, inspirada na velha política comteana de renda indígena do SPI. Em outras regiões isso provocou desastres como o surto de malária no Padauiri na concentração junto com outros trabalhadores para colheita de fibras; alega o então funcionário da Funai da época que "eles queriam uma canoa", por essa razão foram agenciados a trabalhar dessa forma. tal concentração e as condições insalubres em que permaneceram produziu um dos maiores surtos de malária dos Padauiri Teripë. no Toototopi, um morador do Novo Demini propôs a produção de carvão para vender em Barcelos; em todos os casos em comum há de se tornarem experiências predatórias tais como o foram as experiências de renda indígena em tempos de SPI. Exemplos pelo Brasil demonstram uma visão arcaica sobre as necessidades indígenas, obrigados a entrar em nossa sociedade na condição de trabalhadores braçais.

Os Yanomami do Alto Marauiá adotam um sistema de dupla residência com características próprias: ambas desenvolvem um movimento pendular de longe e perto da beira do rio e se interiorizam para lugares de onde já vieram. No entanto, a localidade recriada não se sobrepõe à antiga clareira hikariteka suwëpata: esta não é alterada com novas roças mas é valorizada em busca de diversos elementos da antiga roça, bem como os novos que se sucedem, a partir das próprias forças regenerativas da floresta amazônica, cogumelos, animais, pequenas caças. As capoeiras abandonadas são lugares privilegiados em concentrar caça, pois tem uma dinâmica de crescimento e florescimento diferentes; a chamada produtividade primaria, em ecologia, é percebida pelos seus ocupantes; igualmente, a densidade de vegetação, sua estrutura muiitas vezes emaranhada (hixikiwë) provê abrigo para acasalamento e ninho.

Essas duas polaridades, definidas segundo a espacialidade napë de 'beira' e 'centro', são frequentadas numa dinâmica digna de nota: há circulação de pessoas o ano inteiro, ora apenas um grupo se desloca e lá permanece, visitas, pernoites, temporadas... embora eu não tenha buscado um termo dos Yanomami para conceitua-los, a própria prática parece indicar que não se trata exatamente das definições napë de centro e beira: os pólos definem sim um distanciamento dos postos de saúde, do contato com os não Yanomami. mas a ida a essas localidades, o Xitipapiwei, para o Pohoro, o Xamatá para os Komixiwë (Karawe), o Pukima (que os napëpë denominam 'Pukima centro') é utilizado pelos Ukuxita (que os napëpë 
denominam Pukima beira) e pelos Yariwei; no momento anterior a 2009, a situação era um tanto diferente: para a consciência do pessoal da saúde, havia só o Pukima, e ficava na beira do Marauiá; esse povo que se auto-denomina Pukima, se separou do grupo do Raita, e desde então se separou em duas comunidades atuais: o Yariwei e os Ukuxita. Os Yanomami nunca chamaram aquela beira do Rio Marauiá de Pukima, Pukima Teri eram eles, onde quer que estivessem. Pukima, realmente, é uma localidade ao sopé de serra, já nas terras baixas da bacia do Alto Marauiá, onde justamente efetivaram a descida da serra do Xamatá, de onde vieram em rotas que religam às serras na Venezuela. Há uma ligação com suas roças antigas hikaritëka suwëpata ("roça mulher velha"), e seu espaço é particularmente valorizado, em sua nova configuração; as novas clareiras são criadas nas adjacências da capoeira formada da roça velha, onde se inicia um novo ciclo de derrubadas em expansão ou em série, movimento que encontra descrição na literatura pei komosi e pei heaka (o 'traseiro' e a 'cabeça' da roça)(ALBERT 1985:20). Mas as roças viabilizam a presença/ retorno a essa floresta, com todos os significados acumulados nesse convívio. uma malha de significados mais denso do que numa nova floresta sem o mesmo vínculo histórico.

Nesse processo pendular, o novo e o velho assumem seus papéis de ora inovar, descobrir ou inventar novas localidades, criadas num processo de distúrbio (clareira), seguida por uma sere sucessional de ecossistemas e suas características, circundados por florestas cada vez mais singularizadas, pela definição de nomes, características, fatos históricos...Não é o uso recorrente de um lugar, tal como um monumento, que traduz a tradicionalidade Yanomami, mas o seu modo de descobrir o meio, de investigar e usar uma floresta recém ocupada também carrega uma conotação de tradicionalidade. Reig (2013) observa isso em seus estudos sobre os Yanomami de Shitari, na Venezuela. um exemplo que percebo disso foime dado nas caminhadas pela comunidade do Tabuleiro, recém criada, ainda instalada de forma provisória, e a abertura de novas trilhas feitas durante o próprio ato de caçar. Enquanto me explicava o que estava vendo, contava que ali ainda não havia caminho para várias outras comunidades daquela margem do rio. e que era o desafio dele abrir esses caminhos, enquanto andasse reconhecendo a terra, enfim aquilo que nos referimos como 'caçasse'.

A beira, enquanto espaço privilegiado da interculturalidade, cumpre o papel de pólo de acesso, onde se busca o novo, e na outra polaridade desenvolvem-se outros processos, muito mais relacionados às práticas executadas com frequência, por uma floresta conhecida. Foge a essa regra o Pohoro, cuja "beira" está num rio interno, de menor porte, o Rapirapiu, e agrega 
um contingente considerável para um assentamento Yanomami. já tendo tido mais de 300 pessoas (ver figura 15). Albert $(1985 ; 1992)$ considera a população média de uma comunidade Yanomami 50-60 pessoas. Tal desproporcionalidade até a pouco tempo atrás se desmanchou com a ida de parte do povo para o Tabuleiro, outra para Yapahana, outra ainda para Xitipapiwei. Desses tres, apenas o Tabuleiro se deslocou para próximo da calha principal. O Yapahana permanece no mesmo Rapirapiu, a jusante, e o Xitipapiwei está mais distante, nas encostas da serra.

Percebemos a sedentarização como consequência do contato, sendo que boa parte dos profissionais em saúde tem expectativa dessa situação de fato, mas processos históricos são mais complexos e esse trabalho descreve uma situação diversa, incluindo lugares com tendência a sedentarização em função de postos de contato, voltarem a ter uma dinâmica populacional e espacial maior. Isso já vinha sendo apontado por Nilsson \& Fearnside (2011), cujos movimentos registrados indicavam que a tendência de sedentarização relacionada à beira do rio era rompida por dois movimentos: o das segundas residências, ainda incompreensíveis aos profissionais de saúde que ali atuavam, e uma nova onda de deslocamentos e casas novas, descritas nesse trabalho com maior detalhe. Um reavivamento da mobilidade residencial e das divisões coloca um novo parâmetro para os Yanomami: em breve eles se identificarão com seus co-residentes (yahiteripë), mais do que o passado recente, que os designava com base nas residências então existentes. Suas novas casas terão como território ou uma área previamente conhecida, ou por ainda explorar, incluindo aí a abertura de caminhos (poriyo-yo) para outras residências.

O desenho espacial das mobilidades entrelaçadas dos diversos grupos multicomunitários possui características de rede, talvez malha, no caso do Marauiá, o cruzamento entre caminhos do Pukima/Ukuxita/yariwei com o território percorrido pelos Raita teripë; mais ao sul o estouro populacional do Pohoro, primeiro se dividindo em Xitipapiwei, Yapahana, e a recém estabelecida Tabuleiro (Mrakatahupiwei?). O Rapirapi u possui diversos pontos de ocupação histórica; o Pohoroa é uma reaproximação de um assentamento (hikari suwë pata) antigo, histórico; as pendularidades encontradas foram objeto de especulações diversas, entre polos (maior ou menor acesso ao exterior), relações com a caça, todas mediadas pelos Yanomami, com sua inteligência espacial específica e atenta à 'linguagem' da floresta. Tais especulações merecem novos estudos de caso, além do que foi relatado aqui; seja como for, devemos reconhecer a contribuição teórica de Ingold (2010), 
tanto em recuperar o conceito lefebvriano de Meshwork, como na percepção do envolvimento humano nessa teia, malha de nós e relações extensivas. Temos nesse texto um repertório de situações de estabelecimento da moradia, incluindo tempos de moradas recentes e longos, com ou sem segundas moradias, movimentos diversos onde pudemos evidenciar algumas recorrências registradas, tais como o movimento pendular de maneira geral, e sua disposição com relação à capoeira gerada por ocupações pretéritas, não reocupando-as, mas visitando-as.

O estudo indica haver uma ação deliberada em escolher residir nas adjacências de um pouso antigo, pois ali se forma um sistema único, e com aportes de elementos significativos, como atrativos de fauna e peculiaridades para os Yanomami (e para fauna). Apresenta então suas implicações para o corpo teórico advindo de estudos arqueológicos sobre a ocupação da Amazônia, de uma participação mais proeminente das populações humanas amerindias pre colombianas na construção da paisagem. Os Yanomami exemplificam esse processo vivo, com a mobilidade representando um elemento importante de sua Ecologia Histórica. Como questão relacionada ao posto, ao pólo de aproximação da sociedade não indígena, representado aqui pela "beira", aqueles lugares cujo acesso fluvial é o maior determinante, temos que esse movimento também desempenha um papel de manter presente e atuante na lógica Yanomami, de afastar-se e aproximar-se das sociedades não Yanomami. O desafio de lidar com a nova situação de contato intercultural implicou em inovações no uso do espaço territorial, o uso de novas tecnologias, como o barco, as armas de fogo foram incorporadas, depois de conhecidas e desvendados seus funcionamentos; a capacidade de convencimento dos novos parceiros também rendeu algumas vantagens a uns, sem necessariamente responder a expectativa de sedentarização por parte destes. Para isso, a criatividade espacial implicou no uso de uma prática corrente, relacionada à mobilidade, mas respondendo a um novo contexto, o de proximidade e afastamento do posto (pólo de aproximação não Yanomami) refletindo sobre o recente trabalho de Kelly (2016) em que a antimestiçagem é utilizada como um modo de "transformar-se" no outro, sem deixar de ser o mesmo, pode-se fazer uma analogia espacial a essa lógica, em que a mobilidade no sentido pendular responde a esses dois pólos sem abdica-los. À prática espacial de ocupação de novos territórios, os Yanomami desenvolveram habilidades, envolvendo uma configuração perceptiva onde os fenômenos são detectados pelo conjunto de sentidos, sem prevalência de algum. Com isso, abordamos aspectos da chamada 'ocupação tradicional' muito mais pelo modo como ocupam e percebem, e menos por vincular-se a uma dada terra, por conter esta algum monumento. 


\section{Do Particular ao Articular: Yanomami do Homoxi frente às florestas degradadas pela corrida do ouro (1987-1998 e 2013- presente)}

\section{Introdução:}

O contato intercultural foi bastante traumático quando a corrida do ouro foi a protagonista pelo lado não Yanomami. Invariavelmente, a presença dos garimpeiros provocou choques epidemiológicos, desestruturação social e resultou numa alteração das condições sanitárias e ecológicas das regiões afetadas. Grande parte das invasões garimpeiras se concentrou em áreas da Serra Parima. A Serra Parima é um imenso planalto que chega a mais de $1200 \mathrm{~m}$ de altitude, e onde existem diversas comunidades Yanomami, formando variados grupos de aliança intercomunitária. O Homoxi, localizado nas cabeceiras do Rio Mucajaí é a região mais extensamente afetada pela presença garimpeira; ali viviam dois grupos populacionais Yanomami, um constituído de duas comunidades, e outro unificado. Entre 1988 e 2002, boa parte dessas populações migrou para as cabeceiras do Orinoco, em função das dificuldades causadas pelo garimpo. Apesar de tudo, sempre houve um grupo de pessoas que permaneceram na região degradada, os Tirei theripë. O objetivo desse capítulo é identificar o contexto dessa escolha, frente ao modo de vida Yanomami, utilizando-se de uma análise geográfica das transformações na paisagem através do tempo; o aporte etnográfico da minha experiência ali baliza e auxilia a compreensão do observado com as imagens orbitais. Primeiro analisaremos o efeito do garimpo sobre o Homoxi, Alto Rio Mucajaí, no Brasil. Em seguida as trajetórias dos grupos e as paisagens resultantes, muitas já na Venezuela, na Bacia do Alto Orinoco. Analisamos então o contexto que leva o pequeno grupo a permanecer no Brasil, próximo ao posto, na paisagem afetada pelo garimpo; utilizo dado etnográficos de minhas visitas entre 2002 e 2005.

As imagens de satélite são imagens coloridas com falsa-cor, a partir da reflectância captada por três bandas do espectro eletromagnético (bandas 3=azul, 4= verde e 5=vermelho). A vegetação florestal aparece em verde mais escuro, as áreas alteradas, mas com vegetação, áreas de roça ou vegetação de menor biomassa aparecem com verde mais claro e as áreas abertas, cascalheiras de garimpo, roças novas com solo exposto aparecem em rosa, ou lilás, ainda podendo se identificar nuvens em branco, sombras de nuvens ou de relevo em preto, e lagos, espelhos de água cristalino (em preto, também) ou de água turva, barrenta (em azul). 


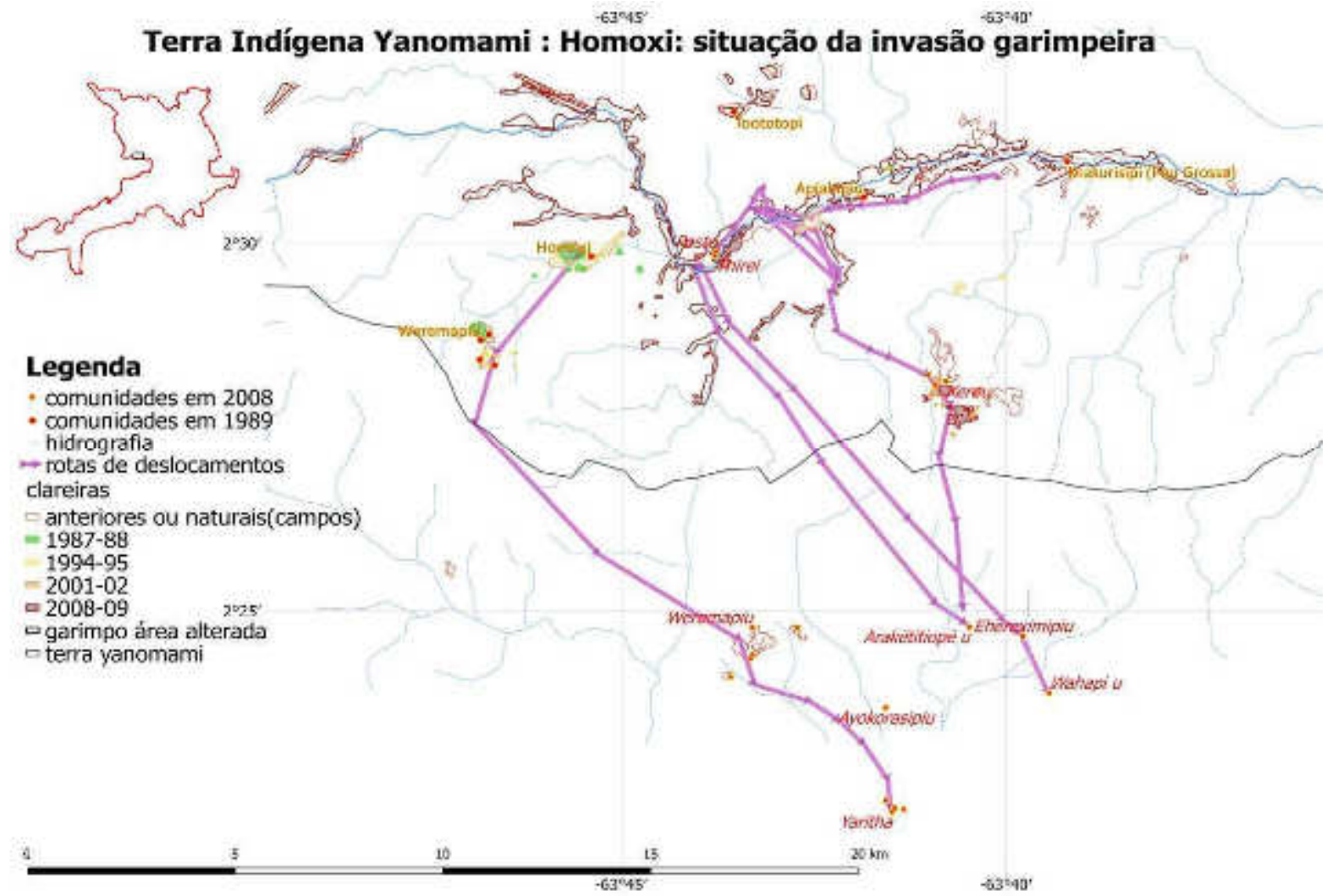

Figura 17: Mapa da região do Alto Mucajaí, Homoxi, e as trajetórias migratórias de suas populações

\section{Trilhas nos escombros}

Homoxi

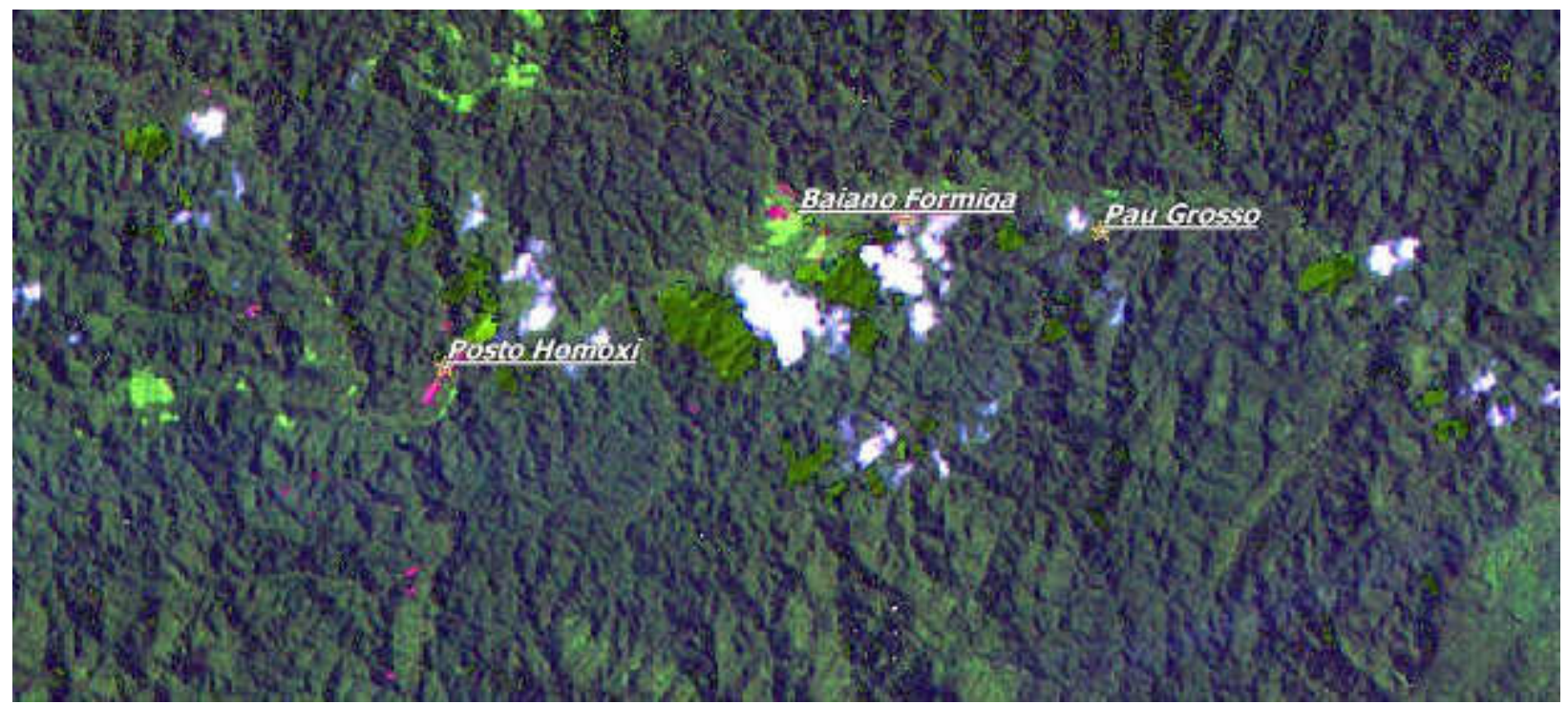

Figura 18: imagem de satélite Landsat 5 TM de 1988 com a região do Homoxi, cabeceiras do Rio Mucajaí

Em 1988 vivia-se o auge do garimpo na TIY (RICARDO, 1991; MACMILLAN, 1995); no Homoxi já havia algumas pistas, a partir da "grota do Tarzan": a primeira a ser construída foi a pista Malária (ALBERT; LE TOURNEAU, 2005), $700 \mathrm{~m}$ de comprimento, a 
oeste da identificada como "Jeremias (Funai)"33. Além dessa, é visível na imagem de 1988 a Pista Baiano Formiga e outras alterações, pois atrai mais garimpeiros e se mostra muito mais dinâmica, nesse momento.

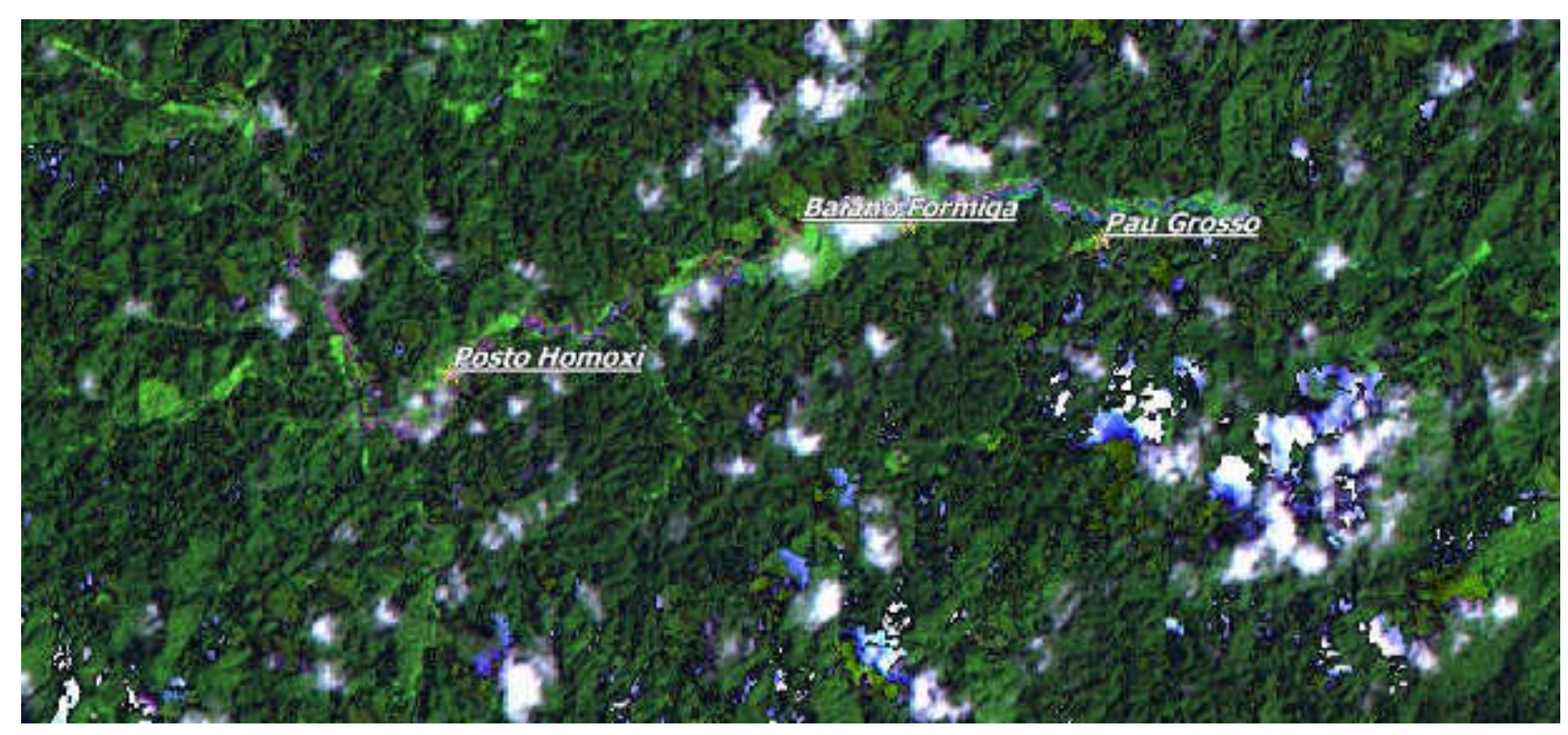

Figura 19: imagem de satélite Landsat 5 TM de 1993 com a região do Homoxi, cabeceiras do Rio Mucajaí.

Na imagem de 1993, após a homologação em terra contínua (1992), houve a explosão de pistas de pouso em várias regiões da Terra Yanomami, o Homoxi aparece como o local de maior degradação ambiental da TIY, sendo o Rio Uxiwau, (Alto Mucajaí) apresenta-se todo escavado e coberto por diversas cascalheiras sem cobertura vegetal. Além da pista Jeremias, já estabelecida, estão visíveis a as Pistas Macarrão e Malária, a oeste; a pista Julio do Blefe não aparece na imagem, mas foi aberta sobre as antigas roças do Homoxiu, grupo que hoje habita o Yaritha.

A jusante da Pista Jeremias, as margens do Rio Mucajaí foram transformadas em cascalheiras e lagoas, onde estão construídas as pistas Chimarrão, Paraná, Baiano Formiga e Pau Grosso. Todas se distinguem no conjunto de áreas afetadas, já sem floresta, beirando o curso do Alto Mucajaí e afluentes. Nesse momento histórico, a relação dos Yanomami com os garimpeiros assume a hegemonia dos segundos. Os Yanomami ora residentes no Tototopi, pequeno curso de água que deságua próximo ao fim da Pista Jeremias, negociam com os garimpeiros o respeito à bacia desse curso, para que lhes restem água potável, havendo grotas por toda parte. Os Yanomami se vêem confinados numa "reserva" em seu próprio território.

33 embora ela só tenha se tornado pista oficial muito mais tarde, com a instalação do posto da Funai (1998) e posteriormente o posto de saúde (2000) 


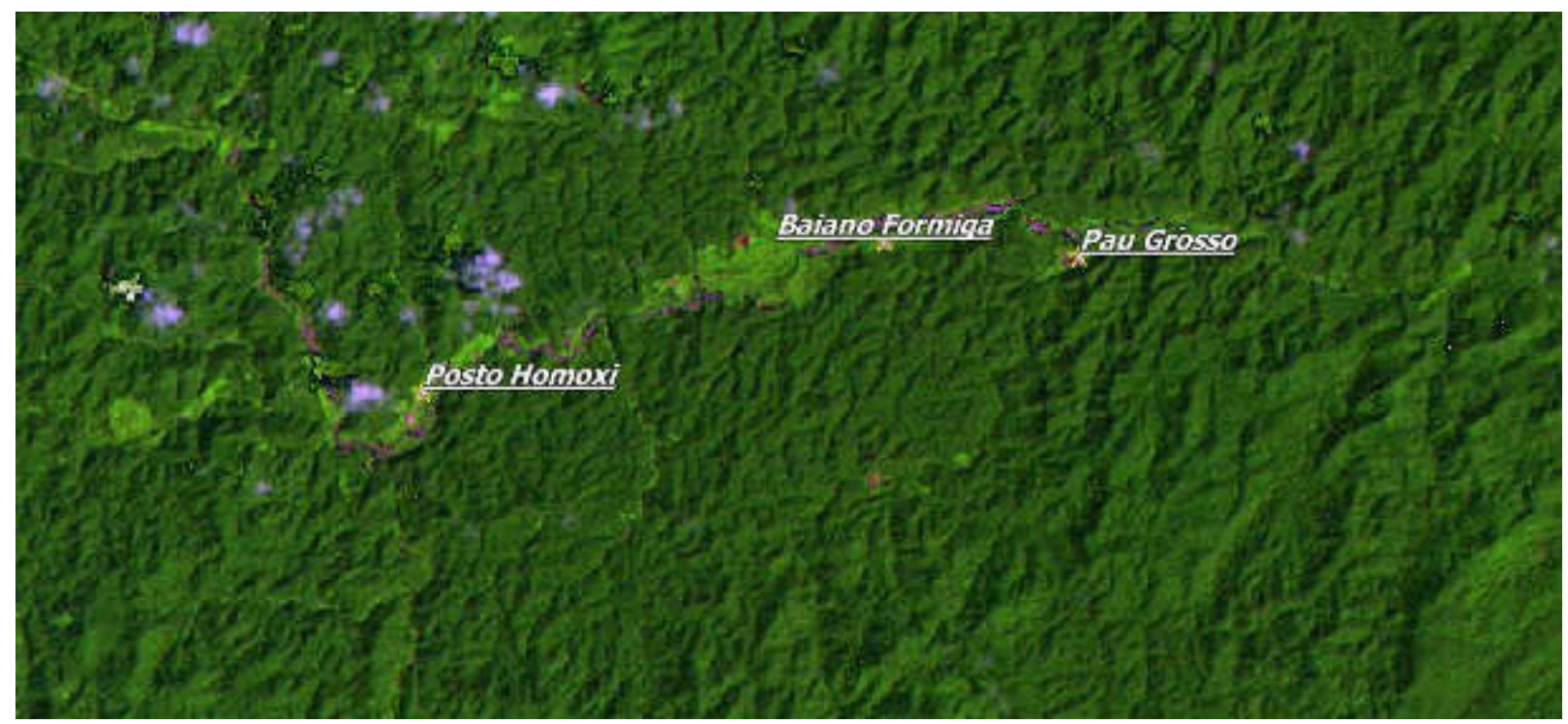

Figura 20 imagem de satélite Landsat 5 TM de 1994 com a região do Homoxi, cabeceiras do Rio Mucajaí.

Na imagem de 1994, já há pistas destruídas, mas Pau Grosso, Baiano Formiga estão plenamente ativas e as lagoas resultantes da atividade são visíveis em toda extensão dos cursos.. Os Yanomami do atual Xereu recorreram ao Apiahipiu para fugirem da onda destruidora da corrida do ouro; Bruce Albert $(2002,2004)$ indica esse momento como uma imersão no mundo do garimpo, onde os Yanomami não têm mais escolha e os garimpeiros pouco necessitam negociar com os donos da terra, pois já são maioria. A desorganização sanitária, social e ambiental já se consolida, com fortes índices de malária e gripe.

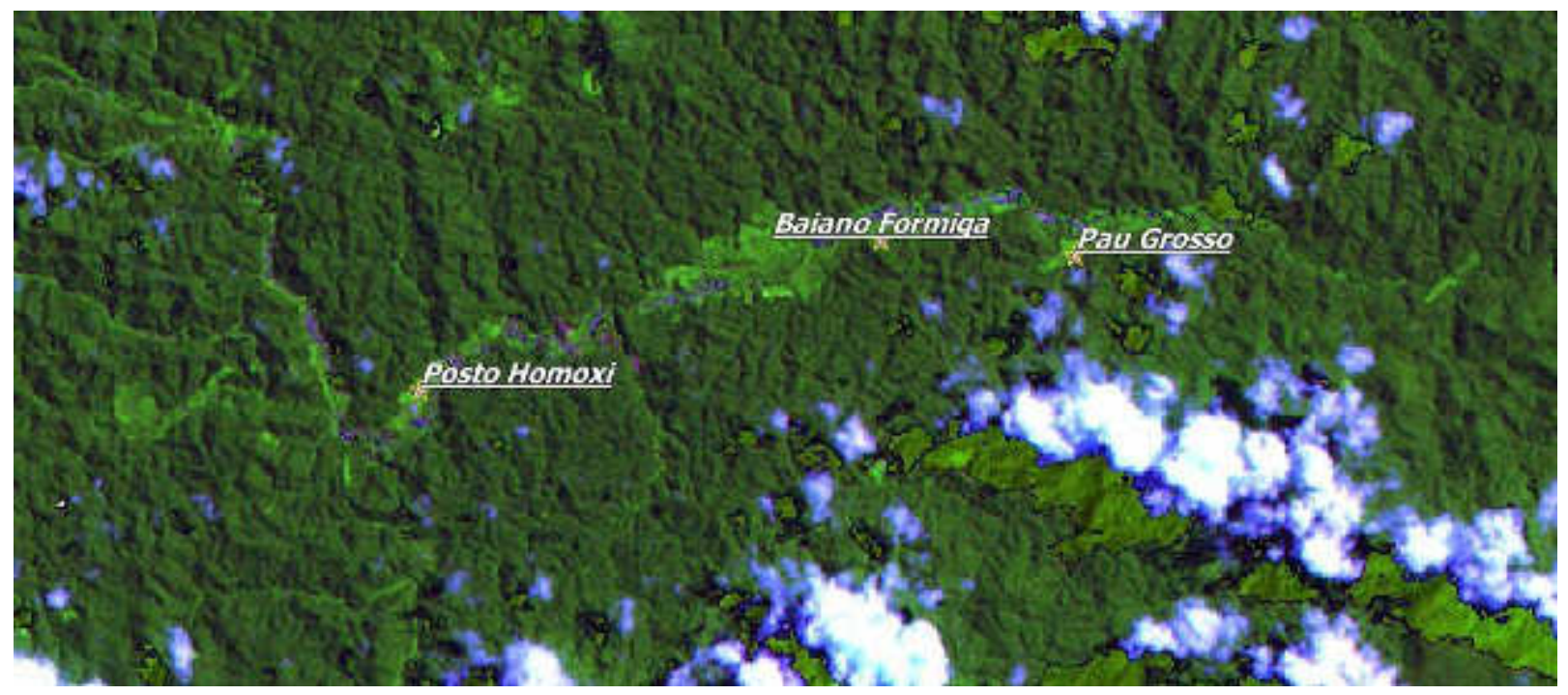

Figura 21 imagem de satélite Landsat 5 TM de 1996 com a região do Homoxi, cabeceiras do Rio Mucajaí.

Em julho de 1996, embora o garimpo reflua na maior parte das regiões da TIY, no Homoxi ele ainda se encontra em atividade; em 1998 são retirados os últimos garimpeiros ativos nas pistas Pau Grosso e Baiano Formiga. Na imagem, são nítidas atividades em grotas 
próximas às pistas do Chimarrão, do Macarrão, Pau Grosso e Baiano Formiga.

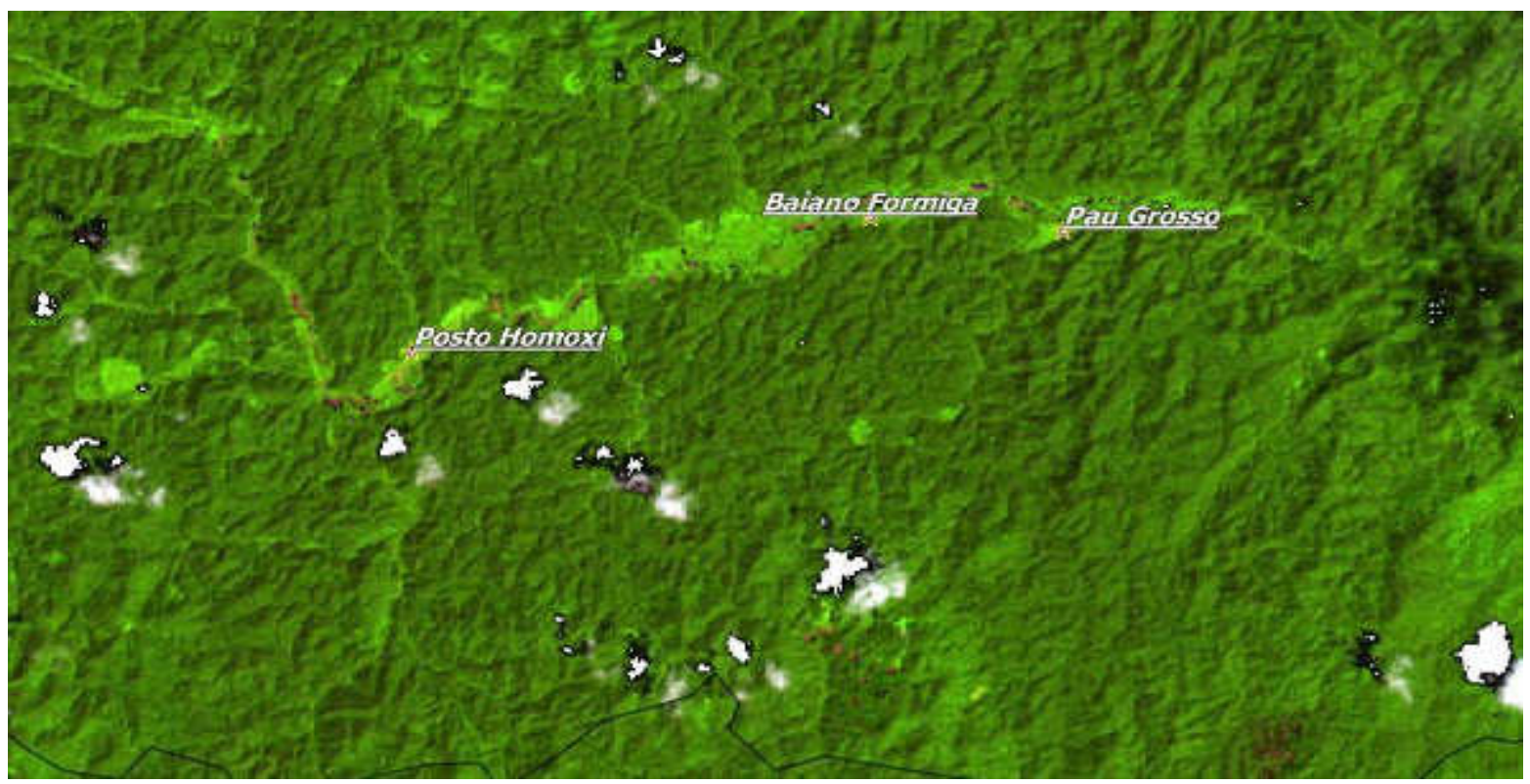

Figura 22 :imagem de satélite Landsat 5 TM de 1999 com a região do Homoxi, cabeceiras do Rio Mucajaí.

Em 1999 as atividades de garimpo praticamente cessam na região mas ainda tarda a recuperar a degradação por ela causada. As lagoas ainda aparentes, a vegetação alterada e a desorganização social impedia a reconstrução das roças na região. A Funasa está instalada a partir da Pista Baiano Formiga, e logo se mudaria para a Jeremias.

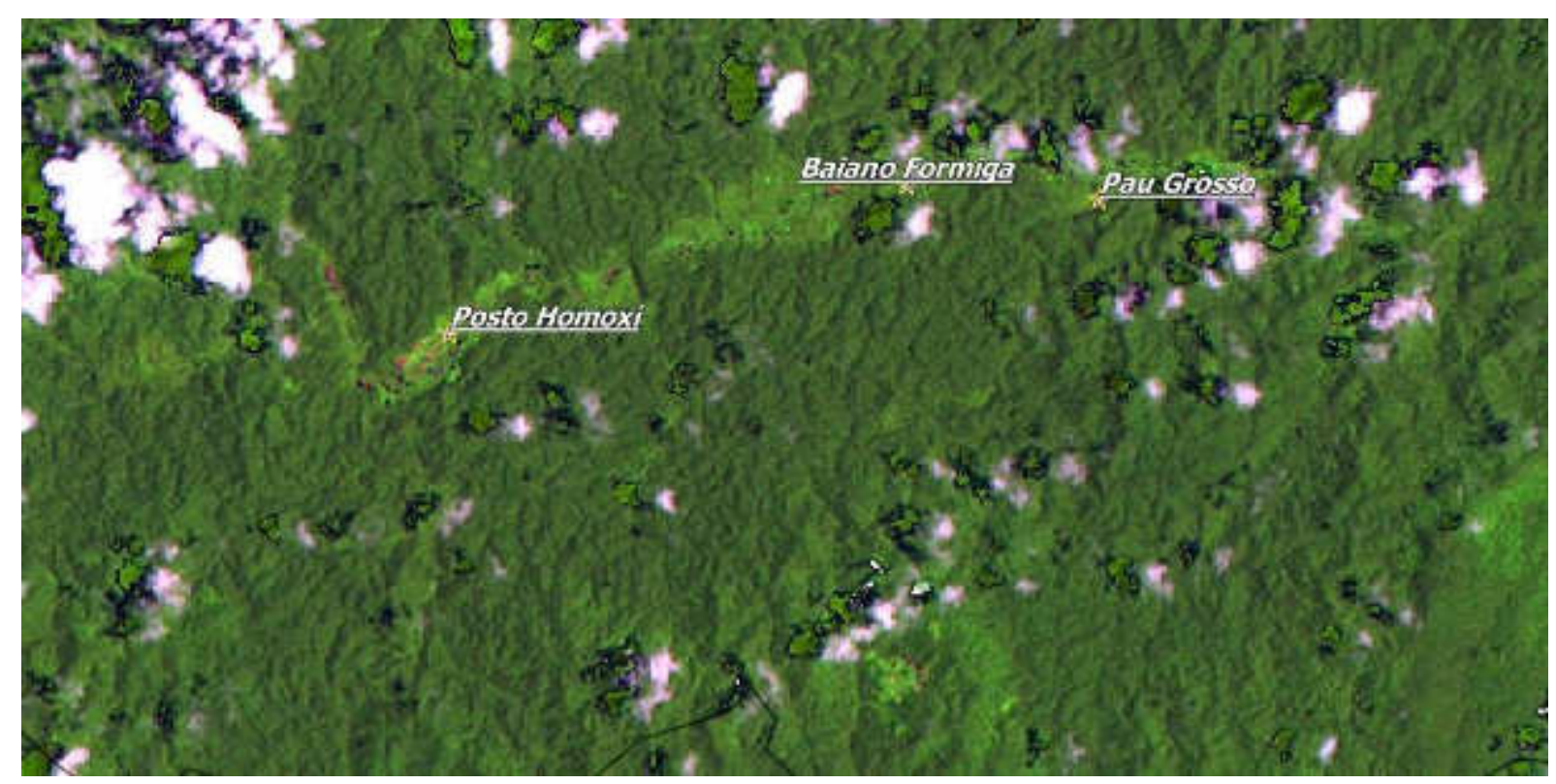

Figura 23.:imagem de satélite Landsat 5 TM de 2008 com a região do Homoxi, cabeceiras do Rio Mucajaí.

Em 2008 temos o mais extenso período de recuperação no Homoxi, já praticamente dez anos sem garimpo, tendo tido a experiência inovadora em educação e saúde na primeira metade da década, a paisagem demonstra tal renovação, incluindo bosques homogêneos de 
kahusiki (Cecropia sp), árvore de frutos comestíveis e atrativos para fauna, e presença de momokiki, frutos da euforbiácea momohi, (Micrantha rossiana) cujas sementes são apreciadas pelos Yanomami. Nesse tempo, houve uma melhora das condições sanitárias, seguida de uma desorganização do sistema de saúde, a partir de 2004; com isso, os Yanomami aumentam sua autonomia em relação aos napëpë, ao pessoal da saúde. Boa parte deles possuíam habitações e roças na Venezuela, ora como segunda residência, ou como principal, visitando menos o posto. Se no início dessa década, já prevalecia um incentivo de promover a saúde com maior presença nas comunidades, a instabilização dos serviços de saúde, a partir de 2004, os Yanomami de Homoxi passam a permanecer mais tempo nas suas casas na região do Hayathau. Mas a desestruturação da saúde resulta num esvaziamento da presença do Estado na região, levando a uma possibilidade de nova invasão que vem a se concretizar, ano a ano culminando com 2016, retratado por imagem do período (Figura 24):

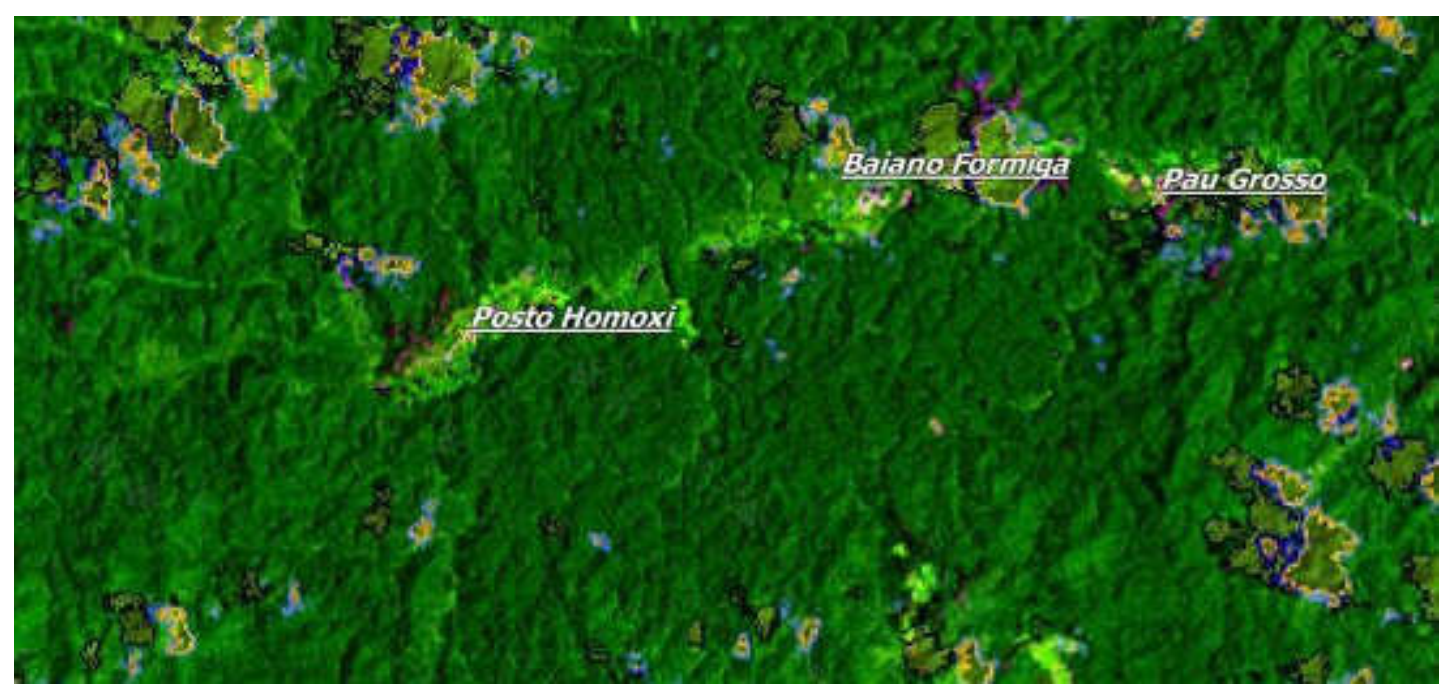

Figura 24:imagem de satélite Landsat 5 TM de 2016 com a região do Homoxi, cabeceiras do Rio Mucajaí.

Essa é a situação atual mostrada na imagem de outubro de 2016: o posto apresenta-se estável, apesar de algumas colinas próximas terem sofrido alterações, provavelmente no início do ano. Observam-se muitas alterações no entorno das pistas Baiano Formiga e Pau Grosso: na região das cascalheiras que margeiam o curso, várias clareiras indicando atividade, e nos morros mais próximos, há alteração também com raleamento da vegetação.

O garimpo voltou a ocupar um lugar de destaque nas relações do Homoxi, e certamente acirrará conflitos com os Yanomami dali, embora possuam casas alternativas na bacia do Alto Orinoco. Em vários momentos de minha convivência ouvi discursos expressando indignação e incompreensão sobre as razões que levavam esses forasteiros a recolherem pedras do chão removendo todo o resto que não aproveitavam e deixando tudo, 
agua e terra, imprestáveis.

Diversos foram os movimentos migratórios que tiveram como motivo direto ou indireto o garimpo. E conflitos abertos pelo fato de estarem tais invasores destruindo as condições sanitárias da floresta. A seguir farei o mesmo tipo de análise aqui focada nos garimpos indicando a mobilidade Yanomami e o desenvolvimento de suas roças e locais de moradia dos três grupos: Tirei, Xereu e Yaritha.

\section{Homoxi/ Yaritha}

Analisaremos a trajetória dos Homoxi Theripë (povo do Homoxi) até sua posição atual no Yaritha e busca compreender as implicações do garimpo nessa migração. Os Homoxi são um grupo atualmente com cerca de 190 Yanomami habitando a Venezuela. Em 1986 eles habitavam a região homônima. Os Yanomami dessa comunidade sempre se posicionaram críticos ao garimpo e, veremos, boa parte das mudanças de residência foram relacionadas à fuga do garimpo e perda das condições sanitárias para habitação.

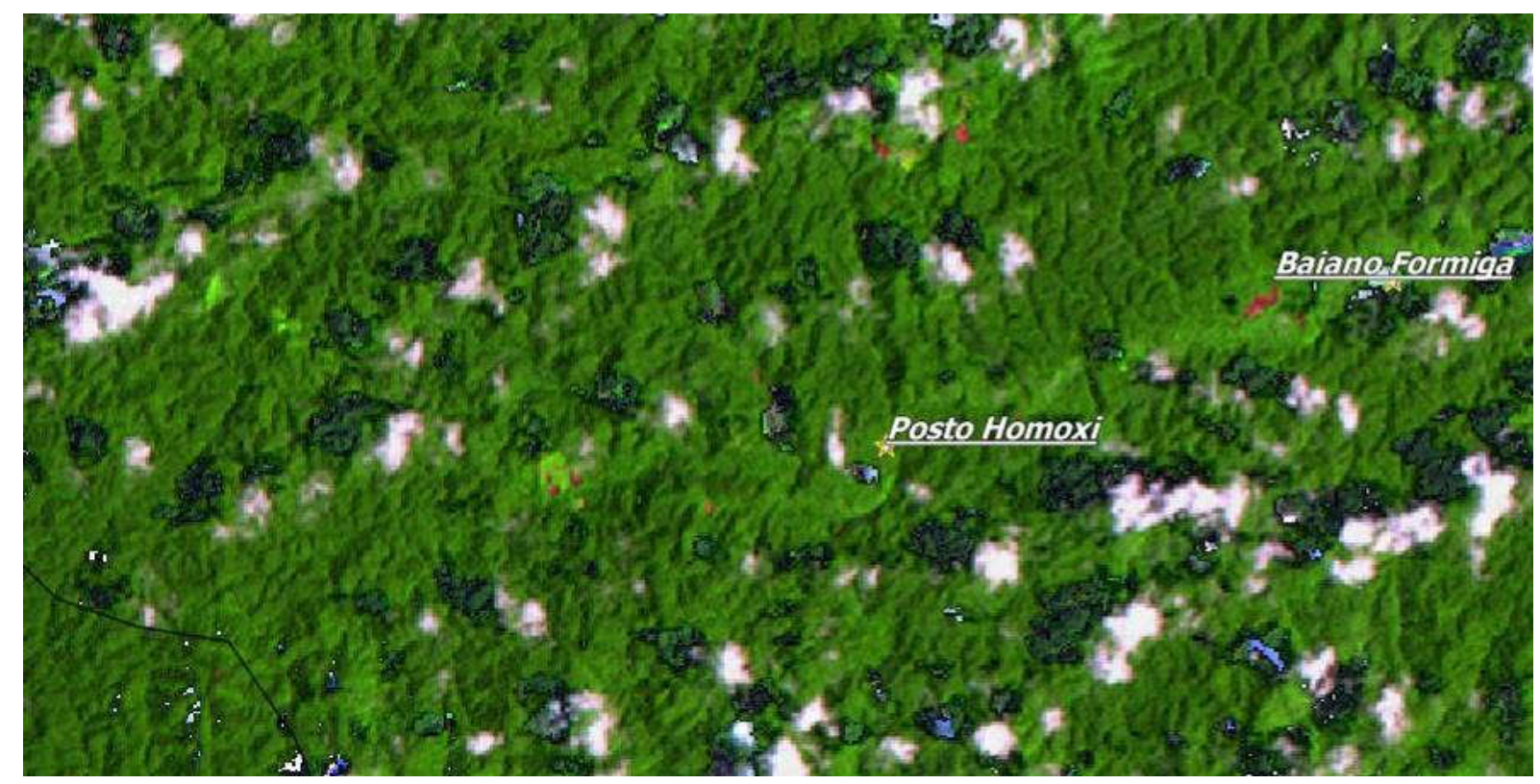

Figura 25: :imagem de satélite Landsat 5 TM de 1986 com a região do Homoxi, cabeceiras do Rio Mucajaí.

A imagem de fevereiro de 1986 (Figura 26) mostra a clareira dos Homoxi, com duas roças novas (dois pequenos pontos vermelhos na mancha verde-claro, à esquerda da imagem) numa extensão das roças velhas, capoeiras e outras em produção. Além das clareiras abertas, mais outra em nova posição na floresta, ao leste da clareira principal. Ao redor, não há pistas abertas (a imagem foca na atual posição da pista do Jeremias) . 
Na imagem de agosto de 1988, a clareira já não está mais habitada, a região ocupada pela presença garimpeira em vários focos: a Pista do Jeremias já aberta, várias clareiras de grotas, associadas ao uso das pistas, que permitiram a intensificação da circulação de pessoas; no caso do Homoxi, os garimpeiros prospectavam e exploravam ouro e cassiterita. Vemos, ao sul dessa imagem, a nova clareira aberta pelos Homoxi Theripë, em região mais montanhosa, quase na fronteira com a Venezuela. Importante lembrar que a localização desse sítio impõe condições mais adversas à produção de roças, menos planas.

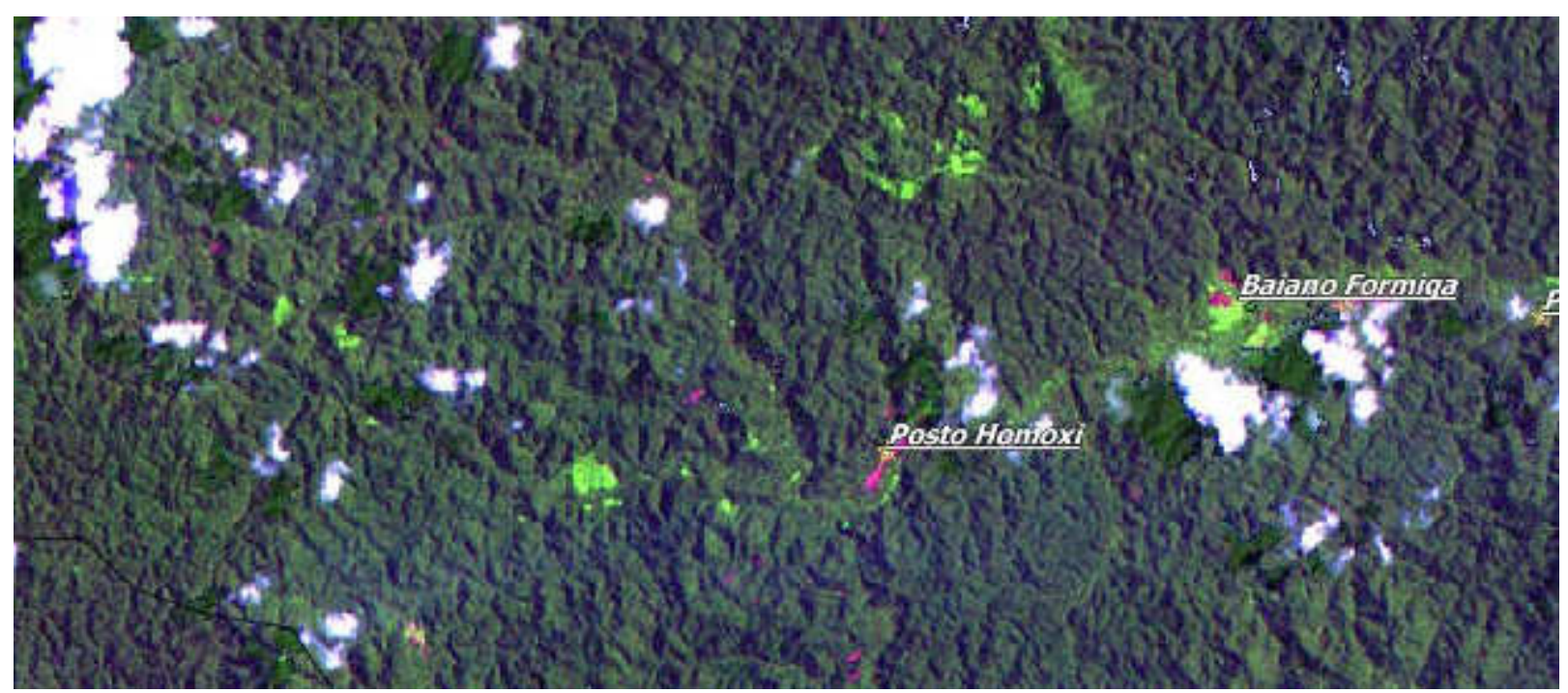

Figura 26: imagem de satélite Landsat 5 TM de 1988 com a região do Homoxi, cabeceiras do Rio Mucajaí.

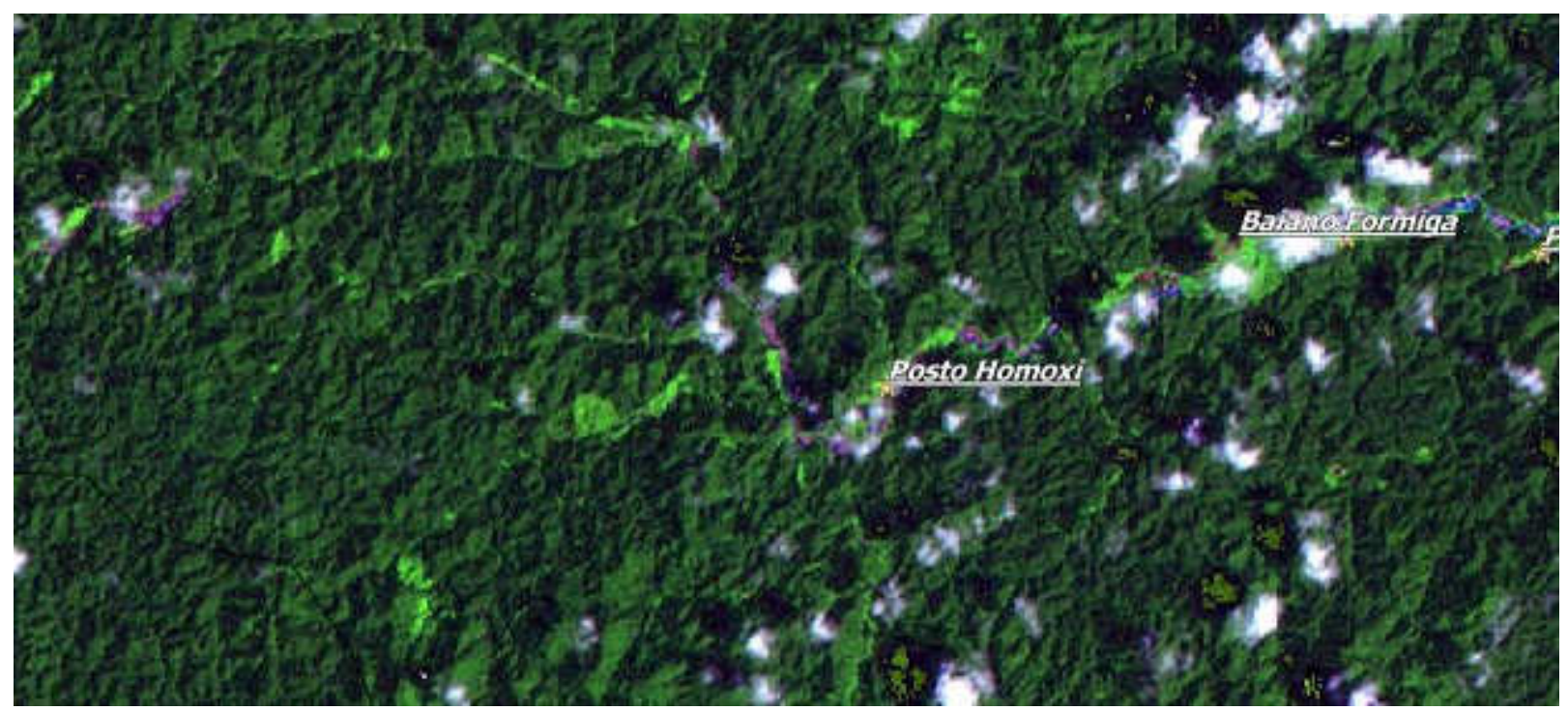

Figura 27: imagem de satélite Landsat 5 TM de 1993 com a região do Homoxi, cabeceiras do Rio Mucajaí.

A imagem de 1993 (Figura 27), a antiga morada dos Homoxi, foi transformada na pista "Jurubreve" (Julio do Blefe), aberta a motosserra sobre o sítio de capoeiras (hutu wãropata) dos Homoxi Theripë; um finado ex-morador foi ao local surpreendeu-se com a pista ali onde era sua antiga residência. O local tornara-se inabitável: restos de garimpo por toda parte; 
cascalheiras, galões de combustível, tambores, restos de máquina e um avião caído. Simultaneamente, o grupo do Homoxi já possuía uma roça próximo à fronteira venezuelana. Ali, abriram mais duas clareiras, uma no caminho (à esquerda, oeste) e outra no lugar onde permaneceriam mais tempo, no Wiramapiu (à direita, leste).

A imagem da Figura 28 (1993, também) mostra o Wiramapiu em uma região de alto de serra, cerca de $1600 \mathrm{~m}$. de altitude, e tendo poucas terras menos inclinadas para cultivo. Tais terras em situação de topo de morro foram e são ocupadas até hoje, com renovação de roças, mas em 1999 (Figura 29) eles já haviam iniciado a abertura de um novo sítio que seria a moradia principal deles nos anos subsequentes. Em 1999 a clareira do Yaritha em processo de abertura está visível ao sul da imagem. O Wiramapiu permanece ativo. Os dois sítios se tornarão concomitantes, como pouso alternativo da outra. Mesmo com o paulatino crescimento do Yaritha, o Wiramapiu mantém suas casas e ainda útil e visitado.

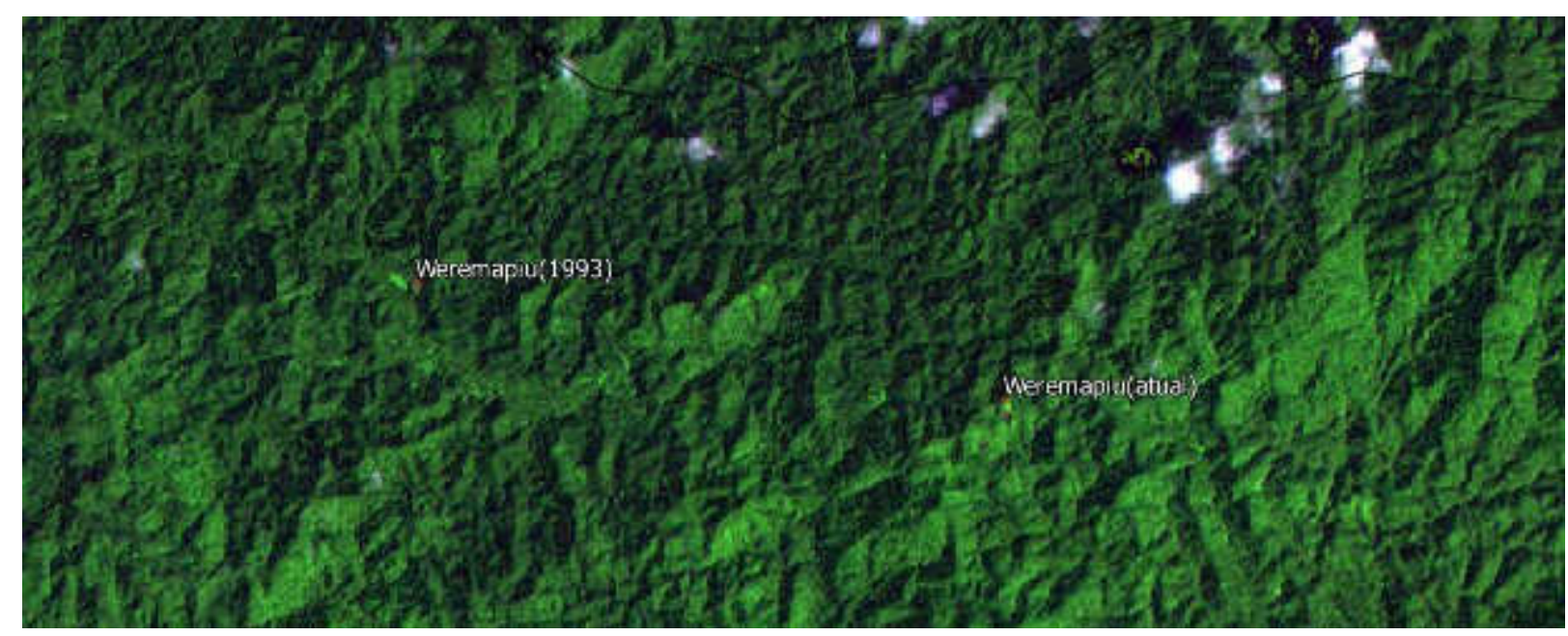

Figura 28 imagem de satélite Landsat 5 TM de 1993 com a região do Homoxi, Brasil e fronteira com a Bacia do Rio Orinoco, Venezuela.

Em 2008 (Figura 30) as duas clareiras permanecem utilizadas pelos Yanomami. Ali já surge a casa do Menininho, Ayokorasipiu mas não se mantém por muito tempo, e o Yaritha permanece residência principal do grupo, mesmo após a morte de uma liderança famosa, pois não foi interpretada como ataque externo. As roças ativas dos Tirei/Xereu theripë, Arakititiopëu, Wahapiu e Ehereximipiu, mantém intensa atividade, os dois grupos habitam a Venezuela, enquanto retratamos uma recuperação ambiental da parte afetada pelo garimpo, na parte brasileira do Homoxi. 


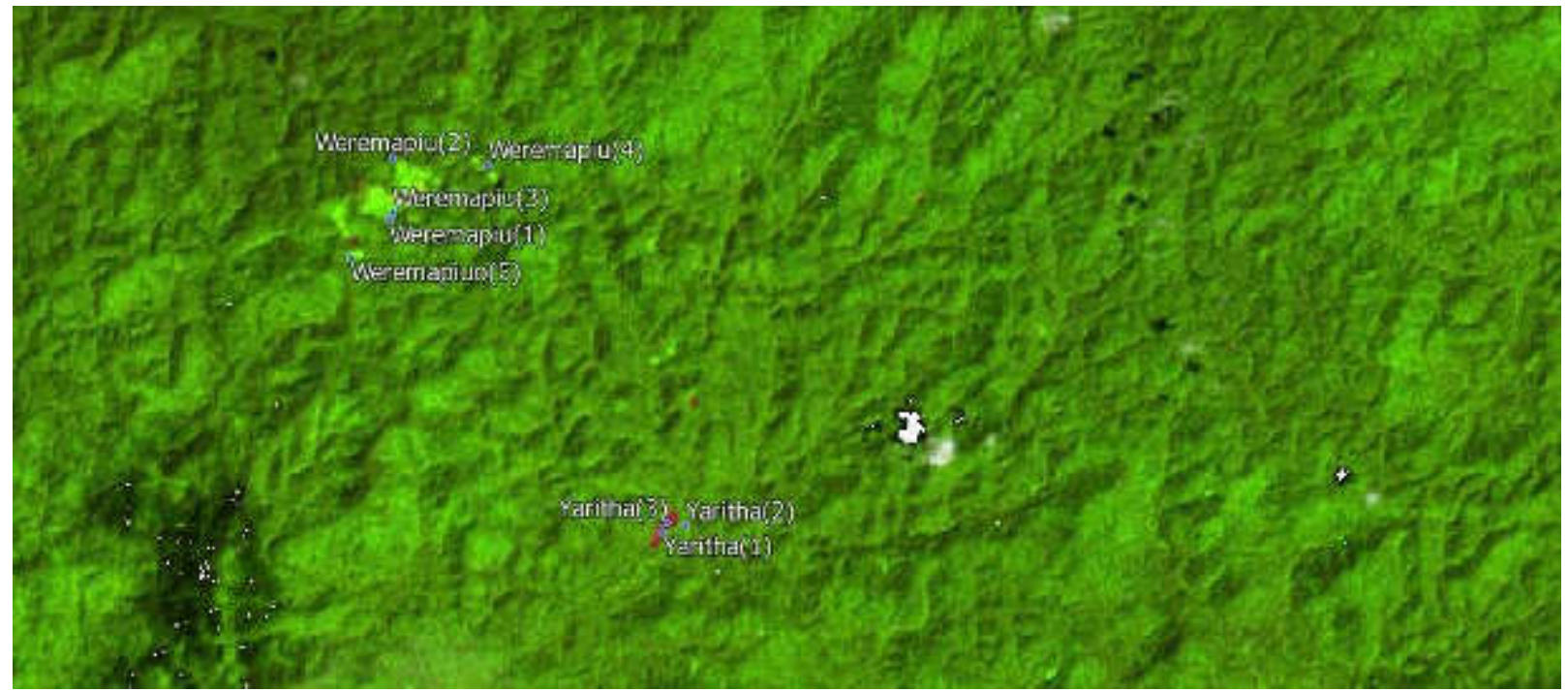

Figura 29: imagem de satélite Landsat 5 TM de 1999 com a região do Homoxi, na Bacia do Rio Orinoco, Venezuela

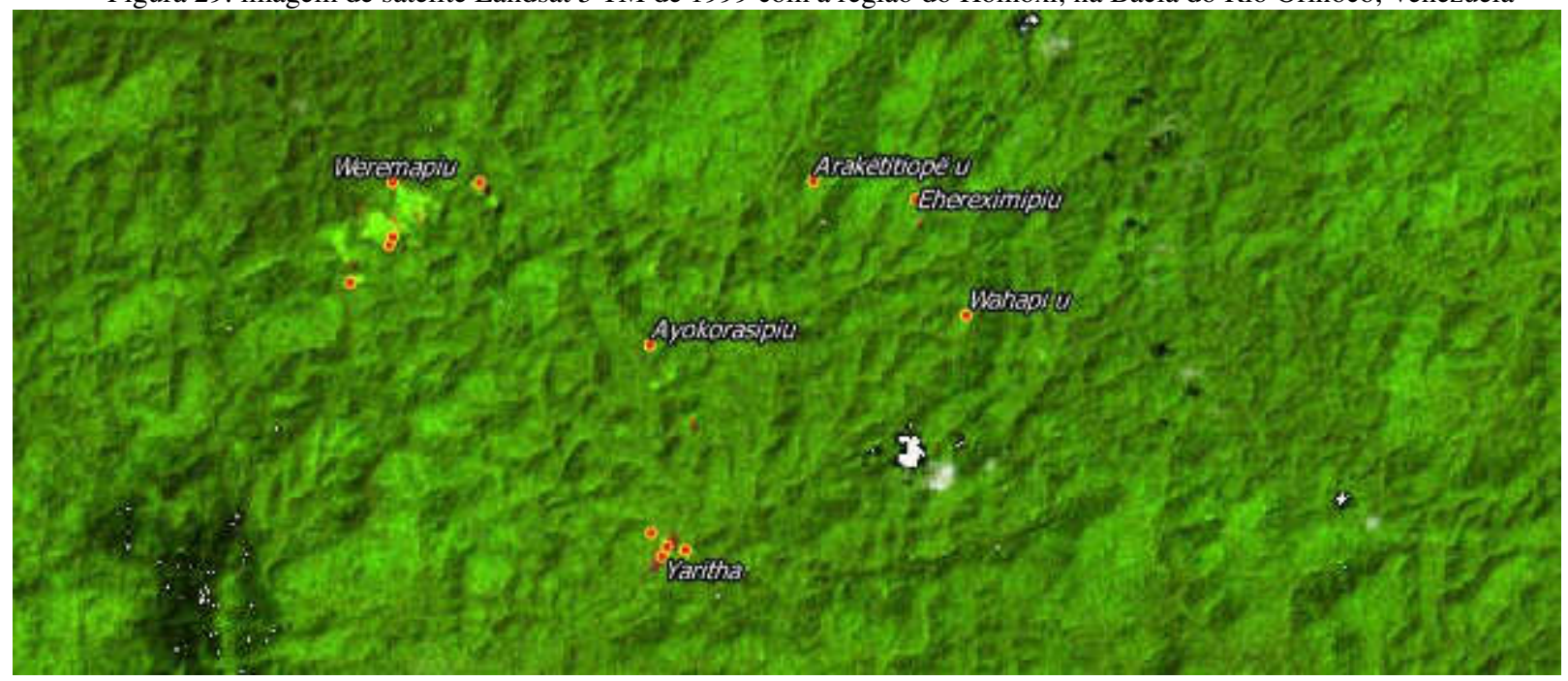

Figura 30: imagem de satélite Landsat 5 TM de 2008 com a região do Homoxi, na Bacia do Rio Orinoco, Venezuela.

Na imagem de 2016, o Wiramapiu ainda permanece ocupado e com roças hoje, mas que a morada principal dos antigos Homoxi Theri tornou-se o Yaritha, ao sul. Yaritha (local com muitas baixadas, com terras planas) fica na bacia do Hayathau, um afluente do Ruapëu em uma região de colinas intermediárias. Suas roças se ampliaram desde sua abertura em 1999. Ali se encontravam quatro casas comunitárias (yano): a principal, a de Menininho, a de Ceará e a de Paulo; permanecem, com uma profusão de roças em abertura e produção. Há porém um fenômeno de raleamento da vegetação nos topos de morro, coincidindo com um época em que houve uma forte seca, associada a incêndios florestais pela TIY. 


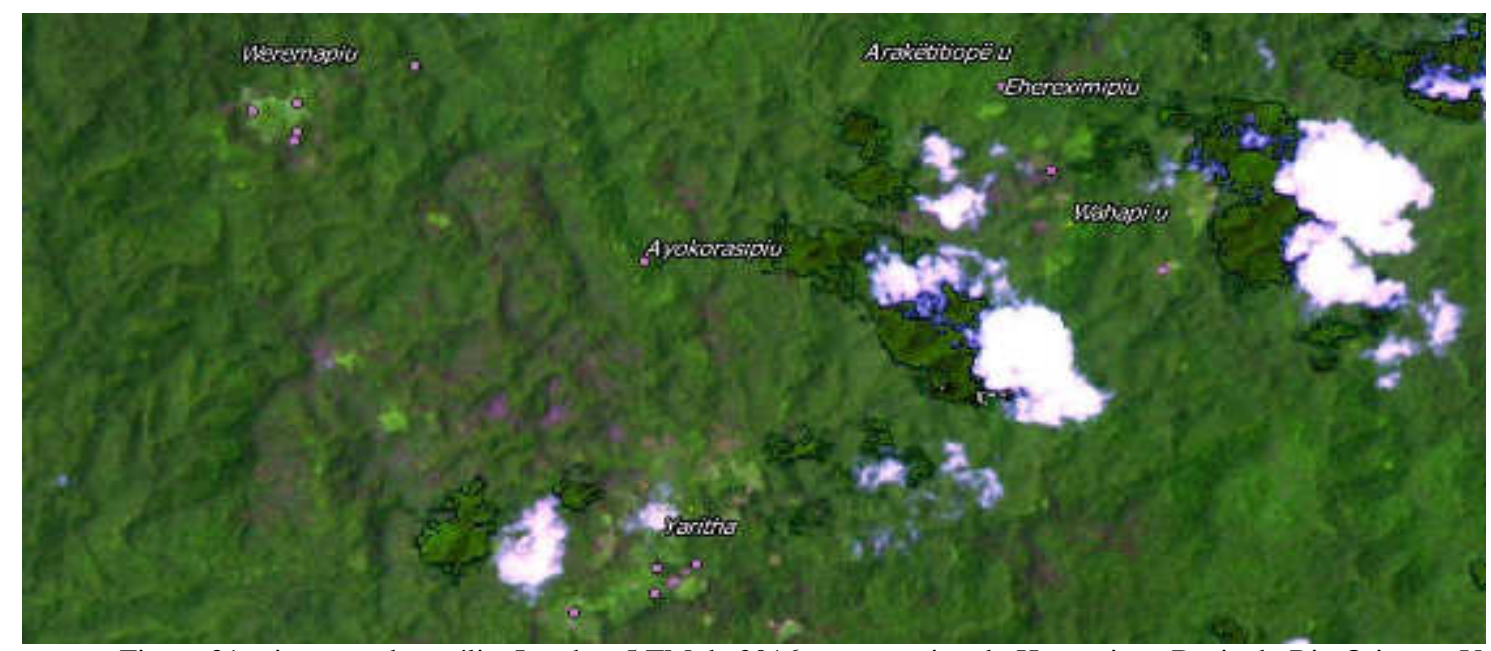

Figura 31: : imagem de satélite Landsat 5 TM de 2016 com a região do Homoxi, na Bacia do Rio Orinoco, Venezuela

A trajetória dos Homoxi/Yaritha Theripë demonstra que boa parte de sua mobilidade teve como objetivo a fuga das condições sanitárias e sociais criadas pelo garimpo, afirmado por eles com clareza. E quando eles encontram uma bacia hidrográfica isenta de garimpo e com terras adequadas ao cultivo e à vida, permanecem ali a um tempo muito maior, apesar das dificuldades com a atenção à saúde. As migrações das décadas de 1980-1990, especialmente em 1988, quando abandonam o Homoxi u, e em 1993, com a ida ao Wiramapiu demonstram que o afastamento da região do Rio Uxiwau era inevitável para o grupo. A insatisfação com a presença garimpeira foi claramente afirmada em vários momentos em que convivi com os Homoxi theripë. Sempre relataram esse período como de dificuldades criadas pela escassez de certos recursos. E acabaram por garantir para si a busca de uma localidade em condições de reconstruir as habitações perdidas para a degradação ambiental. Dentre tais condições, puderam abrir novas roças a cada ano, com sua habitual diversidade agrícola, caminhar pelas florestas circunvizinhas, manter as visitações dos outros grupos aliados, incluindo os Tirei Theripë, os vizinhos do posto nas terras impactadas pelo garimpo.

\section{Tirei e Xereu}

Os grupos do Tirei e Xereu correspondiam, em 2000 a 160 pessoas, divididas nas duas comunidades; o Tirei, optara por viver ao lado da pista Jeremias, próximo ao posto de saúde. O Xereu já habitava a essa época o igarapé homônimo, distanciando-se da calha principal do Uxiwau, afetada pela atividade garimpeira. Em 2002 me informaram que as roças plantadas na Venezuela estavam produzindo; a maioria deles, tanto do Xereu como do Tirei, participavam das três roças abertas que viriam a se tornar as comunidades de Ehereximipiu (Romão, Carlussi) Wahapiu (Garcia, Renato ) e Arakitititopëu (Bauro, Loro). Um pequeno grupo decidiu manter-se no posto, com cerca de 16 pessoas. O que levou esse grupo a essa 
escolha? Como teria sido pensado? Uma decisão de não acompanhar aliados co-residentes, primeira vista parecia ser isolada, uma particularidade. Os Tirei theripë mantinham no entanto as relações de aliança com os outros grupos do Homoxi, visitavam em reuniões de arihimou (em que se preparam bebidas alcoólicas fermentadas a base de mandioca) e levavam materiais de trocas adquiridos no posto. Mantinham seu uso territorial, com coletas de lagartas, de caranguejo e camarões, de larvas de cupim e de frutas e castanhas, como o Kahusiki (Cecropia sp.) e o momo kiki (Micrandra rossiana) a primeira, decorrência das enormes capoeiras formadas em pistas de pouso abandonadas e a segunda uma semente de uma euforbiácea que requer um preparo para torna-la comestível. Torna-se interessante pensar sua decisão como articulada ao conjunto do povo do Homoxi.

O Хеreu encontra-se em uma floresta menos afetada pelo garimpo; após terem morado no Apiahipiu, um afluente alterado do Uxiwau, basicamente com leito de cascalheiras, subiram os morros até encontrarem a confluência de dois cursos, inspirando o nome (Xere- = dividir, Xereu $=$ ponto em que as águas se dividem). O relevo não corresponde ao preferencial para ocupação, pois os morros são íngremes e os vales estreitos, isso obriga a fazer as roças em topo ou encosta, e as casas ocupam o topo de morro. No Xereu, a situação geográfica de um curso encaixado e curvo lhes garantiu certa privacidade e foi-me dito ser essa a intenção, buscavam uma área isenta dos malefícios do garimpo. Um depoimento de João, pata de uma das casas do Xereu revela esse processo de aproximação seguida de repulsa, indignação com o garimpo:

Hapa o tëhë kihami yama kł pirimou kuimał yama ki Tireiha (não o atual local da comunidade do Tirei, mas aquele próximo de onde hoje é o Xitei) yamaki pree pirioma kami ya xo, ipa pata thëpë xo yamaki pirioma. Yama ki pirioni hu koimaiwi, Thothotopi yamaki piriomou koimawii yama ki piriokoni yama ki xoa a ka kii hei urihiha kihi Pothomatha yama ki piriokõwi ihi kõo wei garimpeiro waroho ma...hi! hu xoaoma. Uxua uha, inaha thë kua yaro, hapa o tëhë yamaki waroho mahioma makii yama ki maprarioma yama ki yai maprarioma yama ki tahiapë yamaki pakarai xoaprarioma. Thë urihipë reanapë xoaoma Homoxi thë ãha hiraiwihiha yamaki pirioma. Tirei hami hapa pirioma, kuprarioma Pothomatha, Thothotopi, Mukaxai, yami mahi, Pata

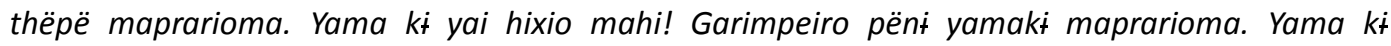
maprarioma. Garimpeiro pëni yamaki wariaremahe. thi tëhë thë urihi proke yama a taarema. Garimpeiro a yai mohoti mahi, garimpeiro peximaimi, yamaki yai hixio mahi xoa. Hapa yamaki nohimamahe "amigo" yamaki thama. wamotima thëpë hipimahe, arroz pë hipimahe, cartucho pë hipimahe, gravador a hipimahe, poo a, Sandália, Kami ya totihi yama pihikuma makii, napë yama pë peximaimi mahi. Hei tëhë ya hixio mahi ipa ya thëpë. ${ }^{34}$

34 Antigamente, quando a gente morava lá no Tirei, nós morávamos juntos, eu, os meus anciãos; dali, nós viemos para o Thototopi, e dali ainda voltamos para o Pothomatha e lá naquela floresta do pothomatha, já havia muitos garimpeiros! Nós seguimos então e no Uxuau (Rio Mucajaí), e sendo assim, se nós éramos muitos antigamente nós nos acabamos, nós quase terminamos e nos dividimos ainda, nossa floresta ficou quase sem gente essa que chamamos de Homoxi, onde nós vivemos. No Tirei nós vivemos, Pothomatha Thothotopi , 
João Xereu Theri, em janeiro de 2003

Se num primeiro momento os garimpeiros se fazem de amigos, sua atividade deixa claro o preço de tal generosidade; a destruição do equilíbrio sanitário e ambiental resulta em necessária mudança, em busca de lugar mais conservado. Desde a água limpa, sem lagoas que facilitem a proliferação de mosquitos, e com a floresta povoada de animais, são condições a se buscar numa região caracterizada por uma dificuldade maior de caça, pela condição de serras, sobre solos residuais, pouco profundos, a floresta de menor porte, em consequência.

Em região de serras, as caminhadas são dificultadas pelas subidas e descidas; a disponibilidade de caça é menor que nas terras baixas. No Xereu presenciei uma intervenção xamânica, um xapirimou, cujo objetivo era atrair a caça para uma fonte de alimentos onde um dos caçadores havia feito um abrigo de espera, totalmente coberto de palha, onde o animal não veria seu predador, que observa através da palha o animal se alimentar. A presa seria um mutum ou um tucano que vinha se alimentando dos frutos caídos de uma árvore na floresta. Durante a noite inteira, uma cena com dois xapiri kipë dominavam o interior de uma casa redonda, envolvendo gritos, encenação subindo ao alto do mastro principal da casa, e representavam à sua forma a cena da aparição da presa. Segundo conversei com o caçador, o xapirimou fôra encomendado porque, tendo ele observado a dias o hábito do animal, e montado o abrigo de espera, faltava ainda o animal ser atraído novamente para o local, debaixo daquela árvore.

Awei hapinaha kami yamakini yama thë thaiha pamarërimakiha mayapapë iyai ha taarini ihi tëhë xapuri thëpëha yamaki ã hai xowa hapinaha yamaki kuuxowa. Awei xapuri wamakini ipa pririmakiha mayapa wa pë kemaki, inaha kama e pë kuutëhë mayapa pë nakaihe xapurithëpëni ${ }^{35}$ Professor Amazonas, com base em explicação do xapuri, 2003

Tendo respeito pela elaboração político-territorial dos Yanomami, não se tratava de um vício como pudesse supor os profissionais da saúde. Tratava-se de uma decisão deliberada e melhor explicada compreendendo uma articulação política com os outros aliados que

Mucajaí, sozinho demais, pois os velhos morreram. Nós ficamos indignados, os garimpeiros acabaram conosco, acabaram mesmo! Eles estragaram conosco! E assim nós vimos a floresta vazia. Esses garimpeiros são muito ignorantes, nós estamos indignados, não queremos garimpeiro aqui! Antes eles nos fizeram de amigos, "amigo", diziam, deram comida, arroz, cartucho, gravador, calção, sandália, "eles são legais" a gente pensou, mas hoje não queremos esses napëpë, hoje eu estou muito indignado pelo meu povo.

35 Sim da seguinte forma nós fazemos quando montamos uma tocaia (um abrigo de caça)e depois de os tucanos terem avistado, nós falamos para os xapuri, ainda,e é assim que falamos ainda: sim, vocês xapuri faça cair o tucano na minha armadilha (meu esconderijo de caça ao lado de uma frutífera) e assim como ele diz os xapuri chamam os tucanos. 
produziram as roças na Venezuela. A ocupação de um espaço junto aos napë, enquanto fonte de objetos preciosos e de uma aliança, de proteção à saúde, se tratava de algo fundamental para a segurança dos Yanomami. As dificuldades de ocupar um espaço deteriorado sugeriam que isso fosse feito por um grupo menor. E esse grupo passou a fazer o trabalho de obter ferramentas e outros utensílios para todas as famílias aliadas, que eram solicitadas e logo fluiam para a rede de alianças dos Yanomami. Por sua vez, os habitantes de Venezuela forneciam condições de vida melhores para o povo do posto, sobretudo com produtos da roça, atestando a relação de reciprocidade.

A mobilidade diária torna-se uma ferramenta na busca de alimentos e recursos, numa paisagem transformada pela ação garimpeira. Baseado no sistema de alianças intercomunitárias, mas se colocando como uma comunidade relativamente autônoma, os habitantes do Tirei assumem os dois lados dessa condição, da articular com outros grupos e de garantir subsistência num sistema transformado. A substituição de recursos extintos a curta distância, como a palmeira paahanaki (Geonoma sp.) usada na cobertura de casas e encontrada normalmente nas formações sedimentares fluviais. Parte da cobertura das casas era de lonas encontradas do garimpo, ou de telhas de metal das casas demolidas de postos de contato antigos. $\mathrm{Na}$ busca de alimentos em áreas transformadas pode significar longas distâncias, no caso de alguns recursos florestais. Como o acesso ao naraupë (Copaifera sp), encontrada em área de altitude; os tirei theripë trocam com os habitantes da serra. Isso não difere tanto de processos anteriores de obtenção de alimentos, indicando que os Tirei mantiveram similar domínio sobre o território em novas condições.

A caça de veados haya pë (Mazama sp) se dá com certa frequência próximo ao posto, nas áreas abertas. Correr atrás de veado era cena comum na região da própria pista de pouso, muitas vezes com sucesso. Num dado momento exclamei que ali deveria ser o rio Hayathau, nome do rio que verte para o Orinoco e banha as casas do Yaritha, afinal ali havia muitos veados. Os moradores explicaram que os veados ali caçados tinham origem na região de Hayathau, por isso o nome estar associado àquela microbacia. Assim, temos que a fauna da região da pista de pouso, afetada pelo garimpo se beneficia da presença da floresta no Alto Orinoco, a cerca de cinco horas de caminhada. Os hayapë se deslocam e vêm viver na bacia do Uxiwau, com sua condição modificada de áreas abertas em plena floresta. 


\section{Waipë: inimizades intercomunitárias no Homoxi}

Os conflitos intercomunitários estão relacionados com a ocorrência de óbito, imputada a outro Yanomami, de quem os parentes do morto devem vinga-lo (ALBERT 1985). A vingança pode se dar de uma expedição, ou de alguma forma simbólica. Embora descreva a partir das terras baixas da bacia do Catrimani e entorno, encontramos no Homoxi a mesma configuração descrita. Vamos nos ater a alguns episódios ocorridos de um desses conflitos, vividos no Homoxi e o modo como os Yanomami se sentiam. Além de testar o alcance da descrição etnográfica de Bruce Albert, esse texto objetiva apresentar uma perspectiva diferente de enfrentar as situações de avaliar perigos, onde o estranhamento entre mundo Yanomami e não Yanomami se revela. Pretendo oferecer mais um depoimento, partindo de experiências etnográficas com os Yanomami do Homoxi, da ineficiência em não reconhecer os sistemas rituais como reais, uma postura reducionista em ciência. São eles em última instância os determinantes das circunstâncias em que os humores dos Yanomami, suas decisões e posturas e hábitos só podem ser explicados conhecendo-se toda a representação ritual e o sistema simbólico (ALBERT 1985).

Vou apresentar alguns episódios vivenciados no Homoxi revelando o quão presente estão as dinâmicas associadas à guerra, às inimizades entre grupos de Yanomami. Historiando um pouco, o grupo do Tirei/Xereu mantinha a anos uma guerra com os Haxiu theripë, muito próximos até o período do garimpo. Eles eram dois grupos em aliança no tempo em que os Haxiu moravam no Kuremi. Desde o garimpo e intrigas relacionadas aos utensílios matehipë, entraram em conflitos levando a baixas dos dois lados; esse caso foi relatado, ao fim do período de guerras por Rogério do Pateo e Silvia Pellegrino (2003), quando, através de gravações em vídeo promoveram a comunicação entre ambos, dispostos ao fim da guerra.

Minhas anotações de campo são do período seguinte a isso, em 2002 a 2005, quando vivencio as preocupações com inimizades com os Yopopeki, com o Yarakapiu (em menor grau) e sobretudo com o Okomou, vizinhos aos Haxiu, com este permanecendo neutro no conflito. Os Okomouu formaram, no correr do tempo alianças de Therekëpou $^{36}$, como veremos. A espacialização desses grupos à época estão expostos no mapa da Figura 32. A presença de grupos inimigos (waipë) em quase todas as direções dá uma dimensão de como a presença waipë delimita o espaço de circulação do Homoxi, lembrando a ausência dos Toxahipiu a leste, também tratados como inimigos reais.

36 Antigos moradores do Koxexinapë 


\section{Legenda}

- comunidades em 2008 hidrografia

clareiras

$\square$ anteriores ou naturais(campos)
$\square 1987-88$
$\square 1994-95$
$\square 2001-02$
$\square 2008-09$
$\square$ garimpo área alterada
$\square$ Terra Yanomami
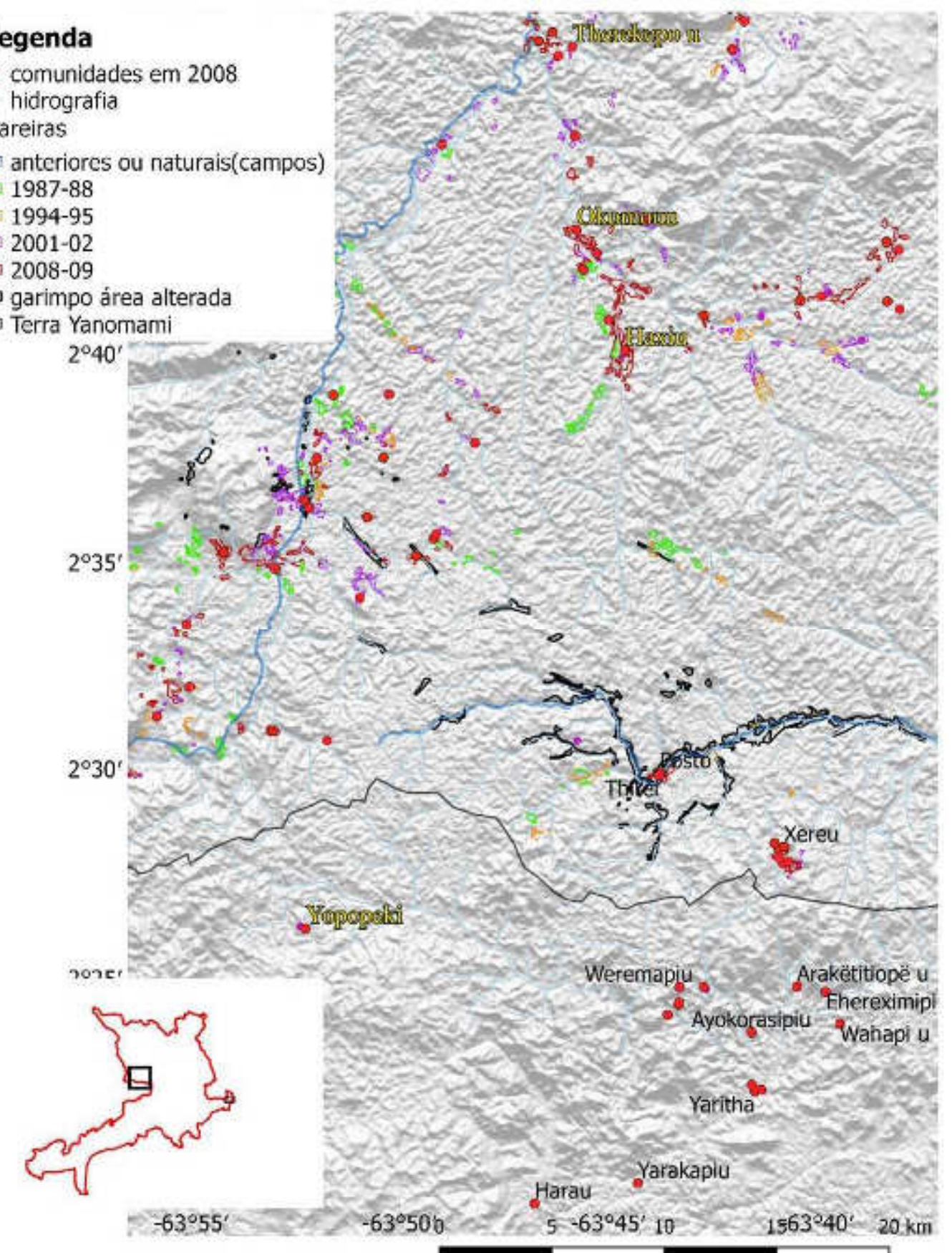

Figura 32: Mapa da região do Homoxi e suas habitações na Venezuela, indicando com nome em amarelo as comunidades com as quais mantinha relações de inimizades entre 2002-2005

Relatarei alguns episódios, extraídos dos relatórios e anotações de campo, durante meu trabalho de acompanhamento das escolas do Homoxi, pelo Programa de Educação Intercultural da CCPY. O propósito é fornecer um mínimo de sensação dos humores vivenciados, e perceber a congruência da descrição de Bruce Albert sobre as dinâmicas sociais dentre os Yanomami; os textos são editados, mas busquei manter minhas dúvidas e ignorâncias para refletir a situação psicológica vivida. 
A mobilidade se vê condicionada às inimizades e alianças dentre os Yanomami, ora impelindo à mudança por fuga ou morte de alguém, ora impedindo a saída, pela insegurança de se andar, sob risco de emboscadas. Não se faz possível pensar a mobilidade em moldes exclusivamente ambientais, sendo necessário sempre entender a dinâmica social dos conflitos e das relações entre grupos Yanomami, fundamentado no seu sistema ritual. Tal como afirma Albert, não se trata de negar a existência de fatores limitantes, mas de entender como fazem os Yanomami em sua particularidade, com sua lógica própria e sua organização social sempre dotado de alguma eficácia (ALBERT 1985:46).

2002: Maranhão se recusa a ir ao Yarakapiu pelo risco de ser emboscado. O conflito envolvia originalmente o Tirei e Xereu(Pothomatha), de um lado, antagonizando com Yopopeki e este aliado dos Yarakapiu, até então neutro, na querela. Os Yarakapiu haviam recém visitado o posto e solicitaram ajuda, com a emissão de gente da saúde:

No fim da tarde chega Maranhão, foragido das ameaças de Manuel; ele deveria ter ido ao Yarakapiu, acompanhado do Ildarkson, porque ele não fala a língua. O Maranhão disse que os meninos do Yarakapiu (em visita ao posto) o ameaçaram de morte, pois haveriam Yopopeki theripë lá. Realmente, o tratamento dado aos meninos do Yarakapiu não foi dos melhores no posto, fizeram um verdadeiro saque à comida deles, quando ainda estava cozinhando. No outro dia, comeram escondidos dentro do posto. Já Manuel o acusou a preguiça do Maranhão como culpada, enxotando-o. Difícil saber a verdade, mas estou propenso a defender o Maranhão, a entender as inimizades e relações yanomami como algo importante para se avaliar uma situação, sobretudo porque Ildarkson não teve problemas lá, pois o Simão, liderança do Yarakapiu, fala português.

Maurice Tomioka Nilsson, relatório de campo de 2002

O texto deixa clara minha ignorância, à época, sobre conflitos intercomunitários: Maranhão, do Tirei, decide baseado em questões que estão longe da capacidade de interpretação da equipe de saúde, representada por Manuel e Ildarkson. Ele tem como parâmetro relações intercomunitárias a justificar sua decisão, mas não a vê respeitada; mesmo sem compreender exatamente a gravidade da situação, coube-me respeita-la. Cronologicamente, as inimizades com Yopopeki se entrecruzam com episódios relacionados aos conflitos com Okomou, posteriores; manterei a ordem cronológica nas narrativas, deixando os esclarecimentos conforme eles aparecerem.

2003 Acidente: Morte da mãe de Rogerio. Este evento, uma fatalidade, desencadeia uma série de outros, como veremos; no entanto, no texto, atento apenas para consequências imediatas, tais como o fim das aulas, minha aproximação com as crianças, pois elas se mantiveram bem dispostas e brincalhonas. 
No dia 25 de agosto mais um dia de coleta combinado, mas ainda de manhã um acidente interrompe a rotina: vê algumas mulheres, chamando para nós socorrermos uma senhora em quem havia caído um pau bem grande, conforme o relato. Atravessando o Uxiwa u e mais alguns minutos de caminhada pela trilha que leva ao Xereu, num entroncamento à direita, lá encontramos, já bastante debilitada a vítima, nos colos do filho Rogério que chora desconsoladamente.

Não se passaram mais de vinte minutos entre esse primeiro encontro e o resgate, com ela no posto, já bastante debilitada, as tentativas de reabilitá-la, impossível encontrar uma veia para Ihe injetar soro, evitar a muita perda de sangue, o resfriamento contínuo do corpo, o choro contínuo das mulheres e crianças em volta, as conversas com o médico André, em Auaris, e ela se foi. Um pau cai na floresta, sobre a mulher que passa. Lembrar que a floresta onde ela estava era alterada e essa malha de raízes talvez não a sustentasse é tarde. A árvore caiu e mudou o rumo desse trabalho de campo. Agora estão todos tristes, lá na casa Yano chorando, já outros foram convocados para avisar os parentes, no Xereu, usar o rádio no dia seguinte.

Embora um óbito seja sempre motivo de consternação, as interpretações podem variar consideravelmente, e isso muda muito mais do que a tristeza imediata ao episódio; no relato está clara a causa do óbito, os ferimentos e hemorragia decorrentes da árvore caída sobre ela, enquanto o grupo de Yanomami coletavam momokiki, sementes da seringueira branca, num dia como outro. Embora a floresta degradada ofereça aos transeuntes os "paus de viúva" (como diz a população regional), árvores ainda em pé mas com sua estrutura e raízes comprometidas, prontas a cair, em nossa interpretação, claramente temos aí um episódio 'natural', uma fatalidade dotada de azares, inevitáveis, onde só nos resta aceitar. A máxima revolta seria com o garimpo causador de tal desestruturação da mata; no entanto, não é como foi pensado aqui pelos Yanomami. Uma morte será sempre causada por outro Yanomami, mistério a ser desvendado pelos Xapuri, a partir das evidências.

O episódio narrado desencadeia uma guerra com o Okomou; em 2004 eu retorno ao Homoxi, e em visita ao Xereu, encontro Makureba, do Tirei, nitidamente escondido na escura casa de João, em formato de cone, fechado até em cima. Minha rede está ao lado da sua; encadeamos uma conversa, eu relato a estranheza de encontra-lo ali, e ele explica com uma frase: 'você sabe, né?', como se soubéssemos de fato o modo de pensar Yanomami (aprendi sobre isso na leitura da tese de Bruce Albert). Makureba estava em unokai, como Albert explica em sua tese, 'com a marca', ou seja, ele havia emboscado e flechado uma mulher do Okomou e por isso estava 'marcado'. Ainda cheio de interrogações, não havia relacionado os episódios que testemunhei; ele me disse: vc sabe, lembra quando eles mataram uma nossa?, Deixou claro ser aquele episódio; dentro de minha concepção da 'causa natural', o infortúnio de a árvore ter caído, afirmei, ele retrucando ser feitiçaria de rastro, quando pegam um pouco de terra da pegada da pessoa e ali preparam o feitiço. E como sabiam ser o Okomou? Já 
haviam visto o quão eles rondavam suas roças, evidências claras, rastros atestavam sua intencionalidade.

Tal lógica, diferente demais de nossa, guiava os atos dos dois lados, de modo que em 2005 eu o encontrei na Casa do Índio, em Boa Vista, com a ferida de flecha que lhe infligiram as costas, à beira da lagoa no fim da pista do Jeremias, onde ele pescava. Era provavelmente julgado morto pelos inimigos; ali estava, expressão tranquila, sorridente; ninguém sabia sua identidade ali. Havia cumprido o dever ritual. Suas mulheres não estavam mais com o rosto lacrimejado de preto, da fuligem das fogueiras, como é mister à mulher yanomami em luto (Machado 2016).

A situação belicosa, no entanto, apresenta um cotidiano um tanto alimentado pela iminência de uma emboscada, cuidados são tomados, não andar sozinho etc. Sem no entanto isso significar uma situação de pavor: a naturalidade, um cotidiano bem humorado, e tratando a situação como um estado, parte da vida a seguir. A iminência constante afeta as decisões, como vemos nessa situação envolvendo Maranhão novamente:

A filha de Maranhão, Lucia se acidenta e se fere, caindo de uma árvore. O caso, grave, foi objeto de séria discussão no dia seguinte, devido à grande resistência de Maranhão em aceitar a hipótese de remoção em pleno reahu. Ir a Boa Vista, nem pensar. Ele teria de ir ao Posto aguardar a aeronave, e significaria ficar sozinho diante de inimigos potenciais como os Okomouu, que já os havia agredido recentemente. O dia terminou sem solução e à noite Maranhão propôs a ida de Chiquinho, primo de Lucia para acompanha-lo. Como ela não aceitou ir sem os pais, foi a família, o cesto wïa e a auxiliar, experiente, já no dia 22 de março, depois de no dia anterior os Yanomami terem aberto uma clareira para o pouso do helicóptero.

Maurice Tomioka Nilsson Relatório de 2004

De fato, os Okomou andaram aparecendo no posto do Homoxi, enquanto só havia a equipe de saúde; essa, se surpreendeu com a juventude dos expedicionários; No mesmo relatório, relato a volta dos Tirei para próximo do posto, e uma prática rotineira dos Yanomami ali: o treino de arco e flecha, realizado com seriedade, mas em clima eufórico.

2004, 1 de abril: A chegada do vôo vem com o anúncio de que os Okomouu Theripë, acompanhados de mais outras comunidades, perfazendo mais de trinta homens já saíram em direção ao Xere u. E a notícia nova é a existência entre eles de armas de branco. Senti a obrigação de avisar os mais velhos da situação. João, meu pata amigo no Xereu, pediu-me informações e eu pude confirmar que a notícia era verdade. Daí pra frente, de maneira ou de outra, os dias serão marcados pelos preparativos de um possível combate, ou emboscada. A história que se conta, é que após a morte da mulher que havia sido flechada pelos pothomatha theripë, muito tempo depois, houve uma pressão constante na casa dos Okomou para virem vingar essa morte. Ainda, no meio de uma festa, onde foram convidados os Thorekëpou theripë, da região do Koxexinapë, um pata toma mingau de banana koraha upë e depois em sessões de xaporimou ingere maxara $a$ (outro nome da Yakoana, o pó inspirado para realizado xapurimou)e vem a falecer na rede. Atribuem a morte a feitiçaria dos Tirei e esse grupo se torna aliado na guerra. 
Outra notícia da expedição dos Okomou, e relatando a aliança com outros povos do entorno da Serra de Surucucu. Ao compreender o contexto atual das revanches podem conter elementos pós contato, tais como armas alienígenas napëpë.

As armas de fogo, apontadas por do Pateo (2006) como uma combinação perigosa com os antagonismos intercomunitários Yanomami, entram aqui como elemento perturbador vindo de longe; o temor é o conflito fugir de seus enquadramentos rituais, pois como aponta Do Pateo, a partir da entrada das armas pela via da colaboração com o garimpo, em regiões distantes do Homoxi, amplia-se seu uso nos homicídios relacionados a conflitos intercomunitários. Em conversa, uma velha liderança do Homoxi apontava sua preocupação, tendo ele um defeito congênito de mobilidade, demonstrava com um jogo de corpo que, quando o ataque é de flecha, existe oportunidade de desviar-se delas, diferente da arma de fogo; o tom bem humorado aponta ao mesmo tempo para os condicionantes rituais da guerra Yanomami, em pouco podendo se comparar às produzidas pelas sociedades de Estado, apesar da homonímia. O relatório evidencia novamente uma morte que seria interpretada diferentemente por nossa cosmologia como 'natural', ser imputada aos Tirei e Xereu, a ampliar rivalidades, com grupos aos quais os Tirei classificariam como tanomai thëpë, gente não conhecida, sem contato direto, dadas as distâncias.

Na volta do Xereu, chegamos tarde, pois as mulheres se propuseram a dormir no caminho, e os homens retardaram ao máximo a caminhada, com várias paradas. A principal, no alto final antes de se chegar ao Apiahipi $u$, curso de água da antiga morada dos Xereu, próximo à desembocadura no Uxiuau. Nesse ponto fizeram um alvo, durante cerca de vinte minutos preparando o caule de uma musácea para ser flechado. Foi cerca de uma hora de treino, com muitos retornos de flechas e novas tentativas, indicando o clima na região: conforme relatos de alguns, em conversas de rede, ao pé do fogo, alguns guerreiros Yanomami daqui foram vingar a tentativa de assassinato de uma mulher, a Xirlei, que sobreviveu, sendo que a morte de um Tirei theri na pista, não havia sido vingada. O medo de Maranhão em voltar ao posto sozinho não era em vão; ele me questionou bastante, se iríamos leva-lo ao Surucucu (antagônicos ao povo daqui), dei garantias, lembrando ser seu amigo, estava entre os dele, e se algo ocorresse a ele eu também corria perigo, pois os outros tirariam satisfação.

Os treinos de flecha se intensificam num belo espetáculo,com as gritalheiras ao acertarem os alvos. Deliciosa brincadeira para um ingênuo que não sabe do que se trata. 85 flechas atiradas várias vezes.

O clima psicológico de um ataque iminente parece me afetar mais que aos anfitriãos em guerra; esses riem, enquanto cheguei a me aconselhar com colegas de equipe, mais experientes, eles lembram que boa parte dessas expedições fracassam, há um clima de incerteza também por parte deles; os aliados se debatem, uns propõem voltar. Mas a iminência é real, meus anfitriãos tomam seus cuidados e permanecem rindo, enquanto atitude do viver. 
Encadeado ao conflito com Okomou, há uma reavivação dos antagonismos com os Yopopeki, resultando em 2005 na morte de um participante do movimento escolar, nosso amigo, morador do Xereu e filho de um xapuri importante. Antes de isso acontecer, o último evento relacionado a esse antagonismo fôra a não ida do Maranhão ao Yarakapiu, relatado acima. Em 2004 o Xereu saíra em waimihuu, quando um grande grupo acampa na floresta por um tempo prolongado, caçando e coletandopareciam antever o conflito. Em 2005, escrevo:

A única presença Yanomami foi acontecer no dia 11 de maio, em que João e outros do Xereu vieram comunicar a queima de sua casa no Xereu, quando estavam na floresta.

O episódio de Maranhão voltando ao posto, largando o auxiliar Ildarkson no meio do caminho ao Yaritha, ao saber da presença de Yoopeki (ou Yopopeki) theripë em visita aos Yaritha. Ainda alguma conjetura das alianças, a serem esclarecidas: hipótese mais provável: os Tirei/Pothomatha theripë convocam os Yaritha para uma aliança de guerra. Motivos: o Paraná já foi casado com uma Yaritha, Adão também é casado com uma mãe daquela comunidade (Maria). Há indícios de que os Yaritha foram também vítima de um ataque às mulheres, na casa de Menininho, ainda não confirmado. Já vem acontecendo um processo de inimizade e desavenças entre os Yaritha e os Harau, atingindo, ao que parece, também os Yarakapiu, de quem já foram mais aliados

Maurice Tomioka Nilsson, relatório de 2005

Uma inimizade antiga, desde 2002 pelo menos, reaparece em conflito, provavelmente por algum óbito entre os Yopopeki, interpretado como obra de alguma intervenção xamânica dos Xereu. Os Yopopeki são habitantes da Bacia do Orinoco, nas altas serras da divisa com o Brasil, ao oeste das casas aqui relatadas. Eram atendidos pela equipe de saúde do Xitei, esporadicamente, por habitarem o outro lado da fronteira. A distância entre eventos permite uma noção do quão espaçado eles podem ser, o quão esporádica são as manifestações dessa inimizade duradoura. Minha última entrada para o Homoxi foi essa de 2005, prejudicada pela profusão de conflitos e os desencontros comigo, como profissional da educação.

Uma situação de guerra conflagrada transtorna bastante os trabalhos, mas também são consideráveis os problemas advindos das pequenas antipatias entre povos e ruídos nas relações entre Yanomami, com acusações e suspeitas constantes sobre quem não é da própria casa (yahitheri); vou relatar dois eventos a demonstrar tais condicionantes:

O Amazonas passava mal e foi tratado pelo Garcia, xapori do Xereu que the disse ter sido envenenamento por Arawari a causa de seu mal estar. Contou que, por ser de fora (ele é do Kunemari), exceto as pessoas da escola, os outros não gostam dele. Dias depois, numa caminhada pela roça, as mulheres que andavam conosco o proibiram de ir a um dado ponto e ele voltou a repetir que as pessoas daqui não gostavam dele por ser de fora.

Pairava sobre o professor uma condição de inveja, sendo de fora, em vez de filho de uma liderança a assumir o cargo. Ali já residente e adotado, ele e o irmão Xiquinho 
encontravam na escola um refúgio. Considerando a lógica de alianças e as possíveis categorizações, conforme Albert (1985), os co-residentes, mas não parentes, não aliados de sangue estão sempre sujeitos a desconfianças e acusações de feitiçaria, um tipo de feitiço utilizado dentro do universo de aliados, muitas vezes. A escola por sua vez tinha esse propósito de estimular intercâmbio, naquilo que faz crescer o conhecimento intercomunitário; no caso, havia o interesse e a proposta de 'alavancar a escola', com a ida de dois estudantes do Homoxi para o Toototopi, como já havia acontecido antes.

À noite, Tiririka escreveu no computador que "não quer ir mais ao Toototopi, pois Afonso teria sido envenenado com feitiçaria de rastro e quase teria morrido",

A feitiçaria de rastro (ver ALBERT 1985, pp.268-273), a mesma teria sido utilizada no caso relatado acima, da mulher morta pela queda da árvore. O Toototopi aparece como um local obscuro e de intenções não necessariamente amigáveis, apesar de velhos aliados, se foram capazes de envenenar ao jovem; conforme Albert, trata-se de uma feitiçaria utilizada contra aliados, também, ainda mais distantes como o são os do Homoxi, no alto da serra, com os das terras baixas.

Um último tipo de conflito cabe relatar: as inimizades e antipatias cotidianas, as quais dei alguns exemplos, podem se estender, em algum grau às relações com alteridades, com os napëpë, em função do que se espera deles. 2004 foi o ano em que houve mudanças na saúde, com a saída definitiva da Urihi- Saúde Yanomami (ver capítulo 3), a organização de saúde que reduziu os índices de malária e morbidade nos locais em que trabalhou, isso provocou uma sensível piora na atenção à saúde, verificável na qualidade de dados, paulatinamente mais obscuros, e na percepção dos Yanomami, menos eficientes. O fato de terem vivido um atendimento realmente eficaz, lhes permitiu julgar o funcionamento do sistema depois das mudanças.

No Homoxi, os Yanomami do Xereu recusaram-se por um tempo a receber equipe de saúde, não havia mais posto médico ali (era uma farmácia feito uma residência Yanomami teto de palha de Geonoma sp, yaahanaki), e estavam indignados com a perda de duas crianças em tempo muito curto, com grande sensação de negligência ou inexperiência médica. A perda de uma vida Yanomami se traduz nos parentes em raiva; a raiva (hixio) é o sentimento a ser aplacado pelas vinganças. Numa das raras vezes em que a morte não é imputada a outro Yanomami, o fôra à negligência médica, e o pai da criança estava com raiva da equipe de saúde e por extensão aos napëpë, indistintamente estávamos eu e o Professor 
(Oriundo de outra comunidade, o Haxiu, e apenas residente ali) em uma das casas do Yaritha:

O professor me chamou de lado e explicou que nós não poderíamos continuar ali na casa do Ceará, pois a mãe deles (do Ceará) tem criado intrigas enfraquecendo seu poder na casa, e soldado - que acaba de perder um filho - depois de ter ido ao posto, com eles atribuindo a responsabilidade ao atendimento médico ${ }^{37}$ - ficou com raiva de todos os napë, e perguntou ao Gaucho se "poderia rachar minha cabeça". Gaucho insistentemente explicou que eu não era da FNS, mas da CCPY, que eu ajudava nas coisas, lembrando as temporadas que fiquei em sua casa, mas eles pediram então para eu me retirar da casa.

Outras manifestações desse tipo pulularam nessa época conturbada da troca da gestão de saúde desestruturando um trabalho, com base em apadrinhamentos políticos e interesses alheios à saúde indígena. Mas convém apresentar um outro lado, resultante da condição de ter conhecido um atendimento mais consistente e uma vez percebendo a deterioração desse sistema, partem para uma autonomia maior na área médica; ali aprendi em duas oportunidades, algumas soluções para problemas recorrentes:

feridas que Haioma, jovem filho de Menininho teve nas costas, formando bolhas com um ponto preto, com possíveis diagnósticos de fungo, ou outro ataque externo; lembravam bem as marcas deixadas pela urtiga e pelo cansanção, mas não coçavam, ardiam muito; a recomendação da Auxiliar de Saúde Adonilde, foi de lavar os ferimentos e em seguida passou permanganato de potássio, para desinfecção local. Ora, este não era caso de internação e ele não poderia continuar o tratamento dessa forma. Assim, uma vez retornando à sua casa, procurou o irmão mais velho, Henaxi, que Ihe passou omanama axiki, uma seiva da Couma macrocarpa, árvore já descrita em Milliken/Albert(1999). Em pouco tempo a ferida cicatrizou, secando.

Hoje, são conhecidos os efeitos cicatrizantes de algumas seivas/ látex de árvores amazônicas, incluem-se a Couma e a Hevea. Outro caso refere-se a queimaduras, relativamente comuns já que vivem à proximidade de fogueiras; tal episódio revela os malentendidos dentre equipe médica e Yanomami, e se passa com o Xereu, decidido a não depender do sistema médico. Sobretudo a aceitar as constantes remoções para a cidade, conforme acabou por acontecer nesse novo modelo de atenção à saúde.:

O segundo caso, tratava-se de uma queimadura, numa criança de colo, filho de Xuxa e Sandra (Xereu). O pé da criança havia encostado na panela de água fervente, deixando toda a pele da parte superior do pé colada na panela, uma exposição que ia dos dedos até quase as canelas. A profissional Lucidalva, ao ver o pé untado em uma massa preta, julgou que os dedos não se descolariam, e conversou com o médico Sidinei, que foi convencido da necessidade de hidratar a criança, para evitar febre e perda de líquido na parte exposta; e se possível, remoção. As divergências começaram aí, pois a hidratação teria de ser por via endovenosa; os pais relutaram em aceitar uma segunda chance de "furar" a criança, de encontrar uma veia, pois a primeira foi mal sucedida. Causa estranhamento aos Yanomami essa prática médica. Sandra fugiu com a criança. A questão da remoção, foi um pouco mais complexa, pois Xuxa, com dor de dente, queria ser removido. Chegou a propor ir sem a criança, afirmou ter convencido a sua esposa a ir, e depois ser desmentido por ela, dadas as recomendações do Cláudio Cravatô (Yanomami), pois

37 Segundo informações pesquisadas no diário de posto, essa criança teria dado entrada no posto no dia 6 de setembro, tendo piorado no dia 8, expelindo vermes, e com dificuldade de respiração, foi para o oxigênio e já em estado grave teria sido levado de volta para "a Venezuela", onde teria falecido. 
teve diarréia na casa do índio. Ao alarde médico de que a criança poderia vir a ter conseqüências, eles afirmaram categoricamente que os dedos da criança não estavam comprometidos, e em breve se descolariam e que a pomada de siiriamasiki (Vismia guianensis) garantiria a cura da sua pele. Um discurso de tal forma convincente, apoiado por vários pata lideranças presentes, que eu pedi para repetir o nome do remédio, uma pomada preta feita a base de pedaços de casca dessa árvore. De fato poucos dias depois a criança já apresentava melhora, tendo seus dedinhos se descolado no dia em que a Auxiliar retornou a Boa Vista. O episódio confirma o registrado em livro e artigos (Albert/Milliken 1999, 1996), mas o fato de a medicina tradicional Yanomami ser praticada justifica o registro, pois no atual contexto de saúde pública indígena no Brasil e na Venezuela, isto tem servido como resposta à excessiva medicalização.

Conforme o retrato de época exposto no relatório, não está na atitude do profissional a questão, mas no próprio protocolo médico, pouco harmonizado com as opções reais existentes na floresta, pouco dialogando com ela e pouco tentando se fazer entendida num contexto intercultural. Procedimentos como 'furar' sofrem resistência das mães e crianças, sobretudo, bem como as remoções, quando o paciente pode passar uma longa estada fora do convívio da comunidade e da floresta. Recusar-se à remoção lhes poupava de incertezas e convívios com um mundo contaminado, mas dependia de apresentar uma solução à queimadura e às feridas das costas do jovem; a eficácia farmacológica Yanomami ajuda a resolver os mal-entendidos entre equipe médica e eles; uma consciente e elaborada resposta com atos e compreensão teórica e micropolítica, na condição de sujeitos do processo.

A autonomia experimentada pelos Yanomami inclui uma confiança em seus próprios sistemas e soluções. Dessas, todas encadeadas, resolver problemas de saúde, de ataques xamânicos e mover-se fazem parte de uma malha de habilidades contidas no habitar, implicando numa totalidade. Mover-se por uma floresta, experienciando-a em seus elementos a encontar árvores de onde se retira a cura para certos males, como queimadura e feridas, ou outros muito mais sutis à nossa percepção; o remédio por eles conhecido viabiliza a permanência; se há uma em que apresenta-se uma concordância de diagnóstico está a condição sanitária da floresta, rapidamente percebida pelos Yanomami, ao custo de óbitos e morbidades e pelas medições caras à nossa ciência dura; por meios distintos alcança-se uma concordância na percepção dos fenômenos.

\section{Apontamentos Finais}

As condições alteradas de florestas não tornaram o Homoxi menos valorizado do ponto de vista dos seus habitantes resilientes. Para eles, deu-se uma nova condição atrativa, relacionada ao que o posto proporciona, e mantém assim, uma estratégia eficiente de 
aproveitar tais benefícios ao mesmo tempo em que a maior parte do povo vive alheio à degradação, só recorrendo ao posto por motivo de saúde. Mesmo a saúde não se tornou uma questão de dependência, na visão dos Yanomami: na piora do atendimento, com a saída da Urihi, em 2004, os Yanomami do Homoxi demonstraram se utilizar de soluções melhores do que as apresentadas pelos profissionais do posto: uma criança com queimaduras teve suas feridas cobertas com a resina da Couma sp. Operema axihi, que é hoje reconhecida como cicatrizante.

A polissemia do termo urihi (floresta, mas também terra, território) pode aqui assumir uma de suas acepções com maior profundidade: a de território, parece se destacar, definindose para os Yanomami do Homoxi como um lugar para ser ocupado por eles, independente de sua condição, como ipa urihi (minha floresta), mesmo quando o ambiente florestal já não justificaria utiliza-lo para definir a formação vegetal, não mais florestal. As degradações pelos garimpeiros não lhe tiraram o caráter político de sua ocupação, mesmo tendo alterado sua ecologia ao ponto de exigir adaptações para realizá-la. O quão deprimente possa ser cobrir a casa com lonas e telhas de zinco, na aparência, não desfaz a dignidade de garantir a apropriação do território de morada.

Os conflitos intercomunitários determinam boa parte das movimentações, e podem ser acirrados pelas relações com os não Yanomami, tanto com os garimpeiros, por causarem mortes gerando posteriormente vinganças, com potenciais novas mortes, como com a saúde, quando não corresponde às expectativas, caindo em descrédito e gerando mais conflitos. Deixamos claro, em trabalho recém publicado, as consequências demográficas para a falta de assistência e desorganização sanitária (NILSSON; FEARNSIDE, 2017), apresentando faixas etárias em que a população se viu com mais óbitos e menos nascimentos.

Cabe reconhecer a dívida que o Estado Nacional tem em permitir a deterioração de uma terra indígena pela exploração mineral. A reparação necessária começa por manter a terra protegida. Os recentes novos episódios de garimpagem na região do Homoxi indicam a pouca dignidade que tem sido corrente no trato com os povos indígenas, no caso do Homoxi novamente ameaçados pela atividade ilegal que os têm prejudicado. 


\section{Yanomami isolados: A inteligência geográfica dos Moxihatetema com base em técnicas de sensoriamento remoto}

\section{Introdução}

O isolamento voluntário de populações indígenas (GOW, 2011) era tratado por outros termos, como não contatados (uncontacted) e só recentemente recebeu esse conceito, que tem a virtude de reconhecer o isolamento, não como uma vicissitude, como eventualidade, do tipo 'ainda não os encontramos', mas uma ação consciente de quem evita o contato, como sujeito da ação; Em 2009, Telma Monteiro publica em seu blog uma matéria sobre uma expedição próximo das Usinas do Rio madeira, Santo Antonio e Jirau, em que se utiliza do conceito (VAZ; COELHO et al., 2013). Ele possui a virtude de reconhecer a livre determinação dos povos, e abriu caminho para que as políticas de Estado a respeitem, adotando práticas de não contato; isso foi efetivado como prática desde 1987, mas como política pública mais recentemente, com a incorporação da convenção OIT 169 e o direito de livre determinação, dentro da Funai com a criação da Coordenação Geral de Indios Isolados e de Recente Contato (CGIRC). O foco está na recusa deliberada do contato, onde a população é protagonista de seu isolamento. Essa é a opção de um grupo Yanomami, conhecido como moxihatetemapë por seus ex-vizinhos, recusam o contato, demonstrando se tratar de uma intencionalidade. Em 2011, a Survival International divulgou a existência de um grupo Yanomami isolado (não contatados) e 'desconhecido' no Brasil. Davi Kopenawa Yanomami os havia avistado em sobrevôo, reavivando uma referência antiga e motivando a Funai a criar a "Frente de Proteção Etnoambiental Yanomami”, sob comando de José Carlos Meirelles, à época. Em função da notícia, Bruce Albert me consultou se seria possível localiza-los e avaliar, por sensoriamento remoto as condições em que se encontravam; parte desse capítulo é originado desse trabalho. Partindo do conhecimento de sua existência desde os anos 1970, Albert e Oliveira (2011) propuseram o tema "novos isolados ou antigos resistentes?", sugerindo o conceito de resistência ao contato e trazendo uma outra perspectiva sobre sua existência. O que historiam, está em consonância com Azanha e Otavio (2010): nem sempre a decisão de não contato foi a primeira; vários povos decidem-se por isolar-se, após uma experiência insatisfatória com a alteridade.

Os Moxihatetemapë eram conhecidos de seus vizinhos, nos anos 1970-80, eles 
realizavam expedições a essa comunidade, com reputação belicosa. Os Uxiu theripë, grupo que habitou o Rio Lobo D'almada e que vieram a formar o núcleo central do Demini Watoriki, comunidade atual do Davi, realizavam esse tipo de expedição e traziam objetos da cultura material desse grupo. Durante a década de 1990, não se teve notícias e julgou-se que esse grupo haveria desaparecido, provavelmente sucumbido às epidemias trazidas pela invasão garimpeira. (comunicação pessoal de Bruce Albert). Os Moxihatetema são possivelmente um grupo de filiação linguística Yaroami, uma das subdivisões da Família linguística Yanomami (FERREIRA; GOMEZ et al., 2010; FERREIRA, 2011). Seu nome lhe foi atribuído pelo grupo do Demini, de onde se sabe parte do conhecimento sobre eles; referese ao modo como suspendem o penis (moxi-) pelo prepúcio, mantendo-o entre dois cordões entrelaçados (hatetea) . A postura política do grupo, de recusa ao contato sugere também uma experiência não satisfatória com as alteridades circunvizinhas, lembrando terem os Yaroami sido as principais vítimas da construção da Perimetral Norte, a BR-210, quando, de mais de vinte comunidades no Rio Ajarani, restaram apenas duas; mas outros eventos traumáticos podem ter motivado a decisão, provavelmente com garimpeiros.

As recentes notícias de sua existência trouxeram esperança e preocupação de um grupo não contatado, sem assistência à saúde pudesse estar em perigo diante da nova invasão garimpeira que se instala atualmente na Terra Indígena Yanomami. A possibilidade de contágio no caso de um contato, assim como possíveis ataques de grupos rivais poderiam facilmente alterar o quadro atual de sobrevivência às ameaças.

Sua localização incerta é consequência da alta mobilidade que caracteriza os Yanomami ainda hoje (NILSSON e FEARNSIDE, 2011) sendo ela usada como estratégia para recusar o contato com os não-yanomami e com os Yanomami de outras comunidades. Aferir a localização precisa dos Moxihatetema atualmente é importante para se pensar estratégias de proteção a eles, cuja condição de isolados os coloca em uma situação de fragilidade, possivelmente não possuindo defesas imunológicas contra microorganismos em caso de eventual contato com outros humanos. A possibilidade de um contato inesperado se amplia a medida que estão em uma região da Terra Yanomami frequentemente invadida por garimpeiros ilegais e não muito distantes de vizinhos Yanomami, que podem lhes atribuir intenções maléficas e implicar em uma ação não amistosa contra eles.

A localização da comunidade Moxihatetema em 2011 já foi confirmada por fontes 
Yanomami e por sobrevoos. A pedido de Bruce Albert, por ocasião da redação de seu artigo citado acima, executei a pesquisa com base em sensoriamento remoto, tentando dar conta de localiza-la. Objetivava caracterizar o grupo em questão em relação à ocupação territorial, imaginando especulativamente a base territorial de sua existência, num contexto geográfico de cercamento e cerceamento pelas condições de ocupação e vizinhança em que se encontram. Além dessa parca base material, pretendo especular sobre sua intencionalidade. Esse conceito, emprestado da fenomenologia de Husserl, implica em abordar a existência do grupo de um ponto de vista de ciência humana, incerta e especulativa em certo sentido, mas em busca de reconhecimento das subjetividades, partindo da premissa de haver uma intencionalidade em seus atos espaço-territoriais, e a possibilidade de interpretar as movimentações detectadas por sensoriamento remoto dentro desse quadro.

A questão que se põe nesse capítulo está relacionada às escolhas por eles impetradas, frente à sua sobrevivência, ao devir Yanomami e sobretudo à situação histórico-geográfica por que passa a região em que vivem, sobretudo aqui pautada pela recusa ao contato. Nessa escolha (se temos a premissa de assim defini-la), há uma direção pela autonomia, por manter seu destino auto-determinado. Numa rara condição de socialidade, onde se espera que participem da rede de relações com outros Yanomami, admitindo aliarem-se a algum vizinho, os Moxihatetema assumem assim uma peculiaridade de recusa e resistência à formação de alianças, ou cujos aliados são ignorados.

O uso de sensoriamento remoto, a ideia de registrar num banco de dados trajetórias, evidências dos povos isolados do Brasil constitui um paradoxo, onde o Estado, através da Funai, com o objetivo de cumprir sua atribuição de salvaguarda dessas populações, utiliza-se desses instrumentos. O paradoxo está na aparente violência de 'encontrar quem não quer ser encontrado', pois o objetivo está em sua sobrevivência. Vou primeiro apresentar os resultados da pesquisa de 2011, inédita, seguido de uma arguição sobre a questão da recusa ao contato e o uso da mobilidade como forma de efetivar essa recusa como uma forma de resistência.

\section{Material e métodos}

A Terra Indígena Yanomami possui 9,6 milhões de hectares, e os Moxihatetema tem seu espaço de circulação definido pelas bacias do Alto Catrimani (década de 1980), Alto Apiau (final da década de 1980) médio Catrimani e ao sul do Rio Mucajaí. Utilizando-se de imagens 
de satélite de anos consecutivos, sob interpretação visual, foi investigada a alteração na paisagem de ano para ano, de forma a descobrir a evolução da paisagem correspondente a roças e clareiras nos últimos anos. Utilizando sensoriamento remoto numa interpretação artesanal de imagens de satélite (NILSSON e FEARNSIDE 2011) desenvolvemos um trabalho permitindo a exclusão de outras áreas semelhantes e definir os padrões de roças e mobilidade produzidas pelos Yanomami nessa região. Para esse trabalho utilizamos imagens Landsat 5 de 2007, 2008, 2009 e 2011, e Landsat 8 de 2014 a 2017, de forma a companhar a evolução da paisagem. A mesma região foi coberta por imagens mais antigas, dando conta da inexistência de qualquer vestígio de ocupação humana perceptível nessa localidade (órbitaponto 233-058). Verificada posição atual provável da comunidade, foi feita uma análise geográfica do sítio, permitindo verificar o estado atual do grupo, população estimada e área de roças por ano e uma análise geográfica da situação abordando os riscos que a comunidade corre, em função da proximidade de eventos e populações. A população foi estimada de maneira indireta, através da análise do incremento médio anual, cujos parâmetros para comunidades Yanomami foram estudados anteriormente (ALBERT; LE TOURNEAU, 2007; NILSSON; FEARNSIDE, 2011). O histórico de deslocamento dessa comunidade foi aferido por interpretação de imagens de satélite em busca de sítios anteriores de moradia e suas respectivas clareiras.

\section{Resultados}

Foi localizada uma única localidade que parece corresponder ao objetivo desse trabalho, com coordenadas decimais $\mathrm{N} 2.53^{\circ}$ e W 62.77 . Abaixo a sequência de imagens demonstrando as alterações da paisagem no trecho em questão (Figuras 1-5): notar nas duas primeiras imagens, de 1988 e 1995, a inexistência de qualquer vestígio, ou alteração na floresta, apenas aparecendo em 2007 até 2009; nessas imagens é possível detectar equenos pontos róseos, indicando aberturas, distúrbios, clareiras com padrões bem similares aos encontrados em outras ocupações Yanomami. Numa região com serras, com relevo cristalino, há ali três clareiras numa extensão maior de áreas outrora abertas, com regenerações e roças já em produção. 


\section{$15-12-1988$}

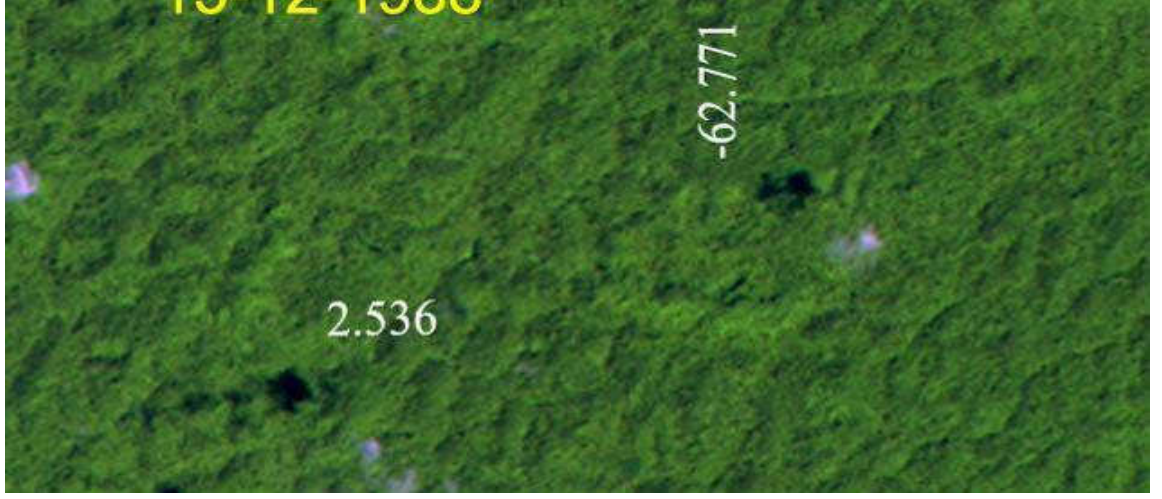
ocupação.

Figura 33: Localidade atualmente ocupada pelos Moxihatetema em 1988, demonstrando ausência de qualquer

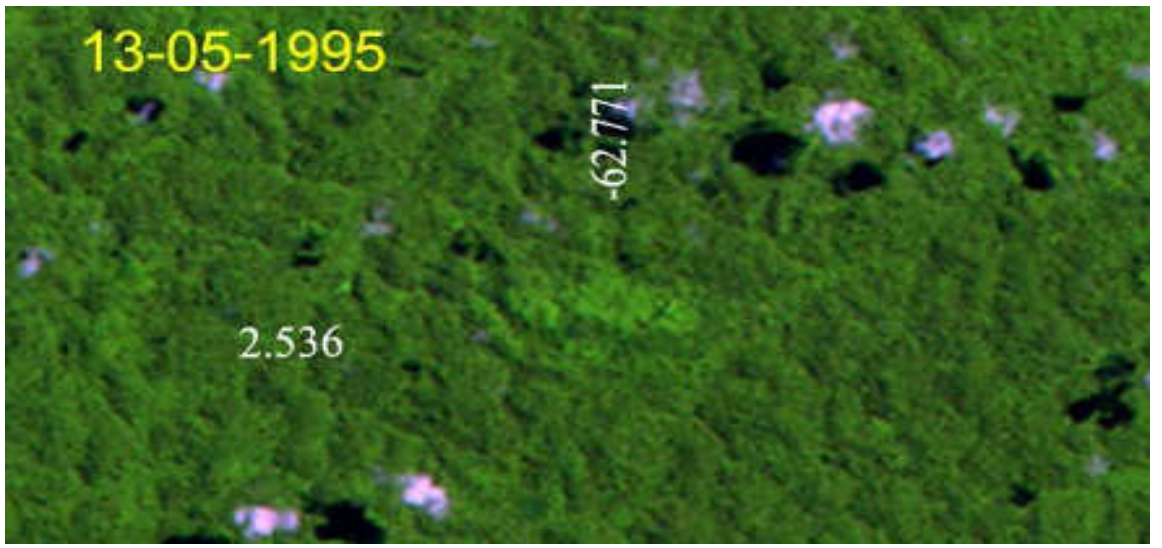

Figura 34: Imagem de 1995 demonstrando não haver ocupação na mesma área.

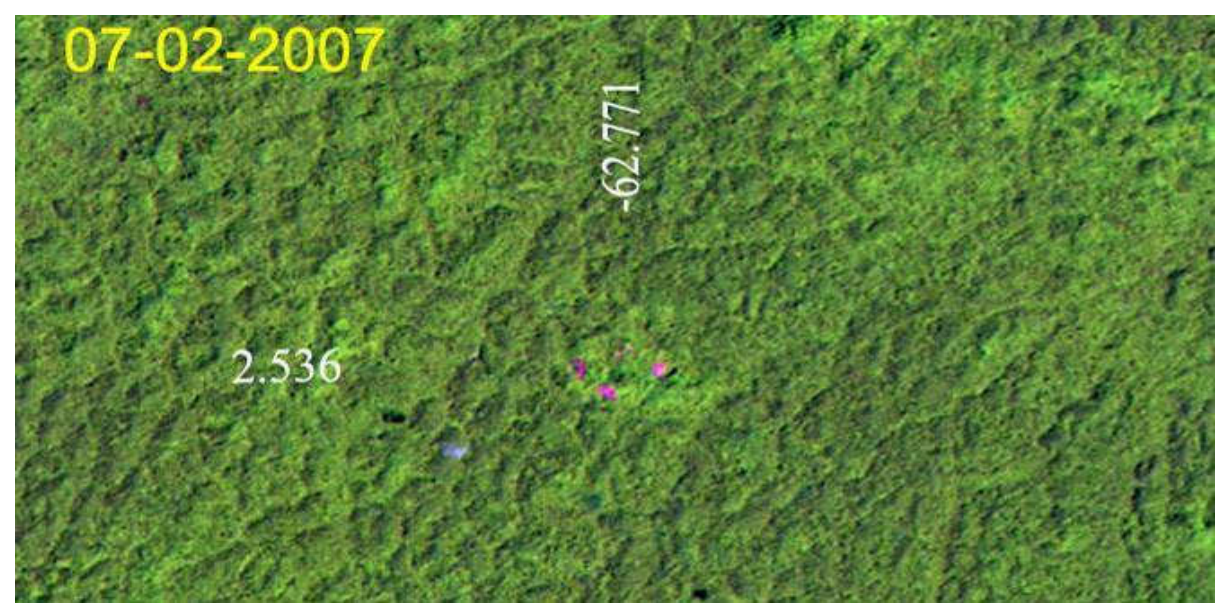

Figura 35: Imagem Landsat de fevereiro de 2007. época de abertura de roças (período de secas) cobrindo a mesma area das figuras anteriores: note o conjunto de clareiras indicando a abertura de roças na localidade. 


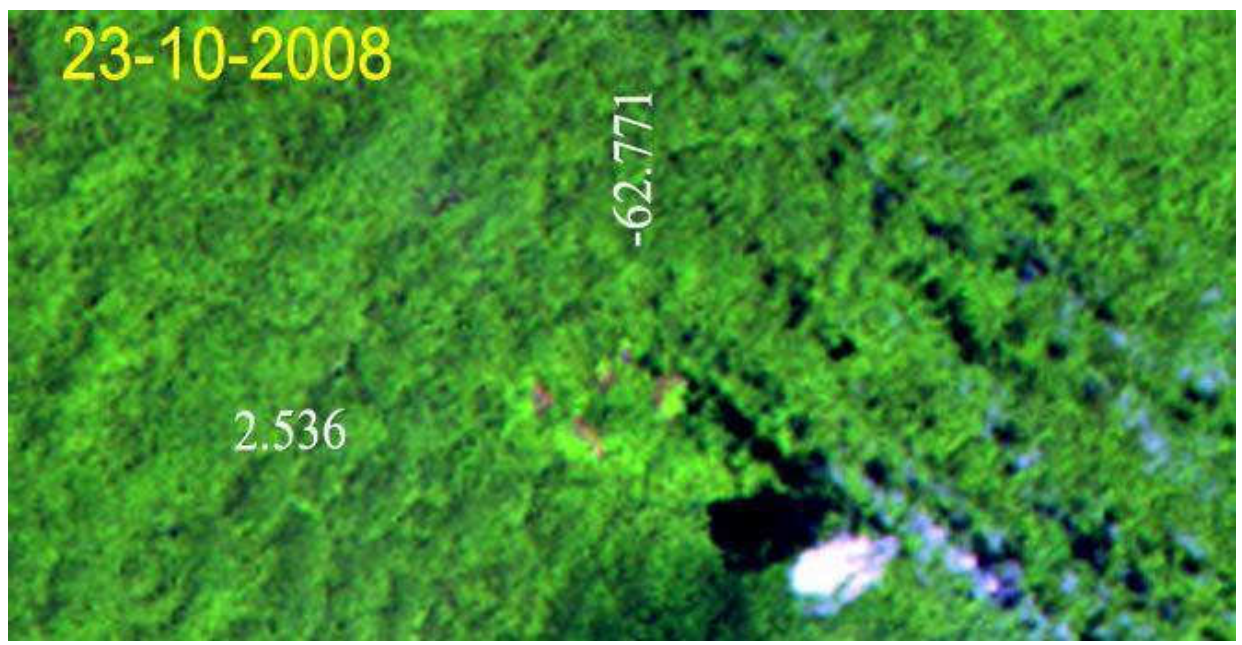

Figura 36 Evolução da paisagem alterada de clareiras, com a área em produção e novas pequenas aberturas, como continuidade do processo de produção de roças em outubro de 2008. Nuvens atravessam a imagem em direção noroeste sudeste, mais uma nuvem e sua sombra.

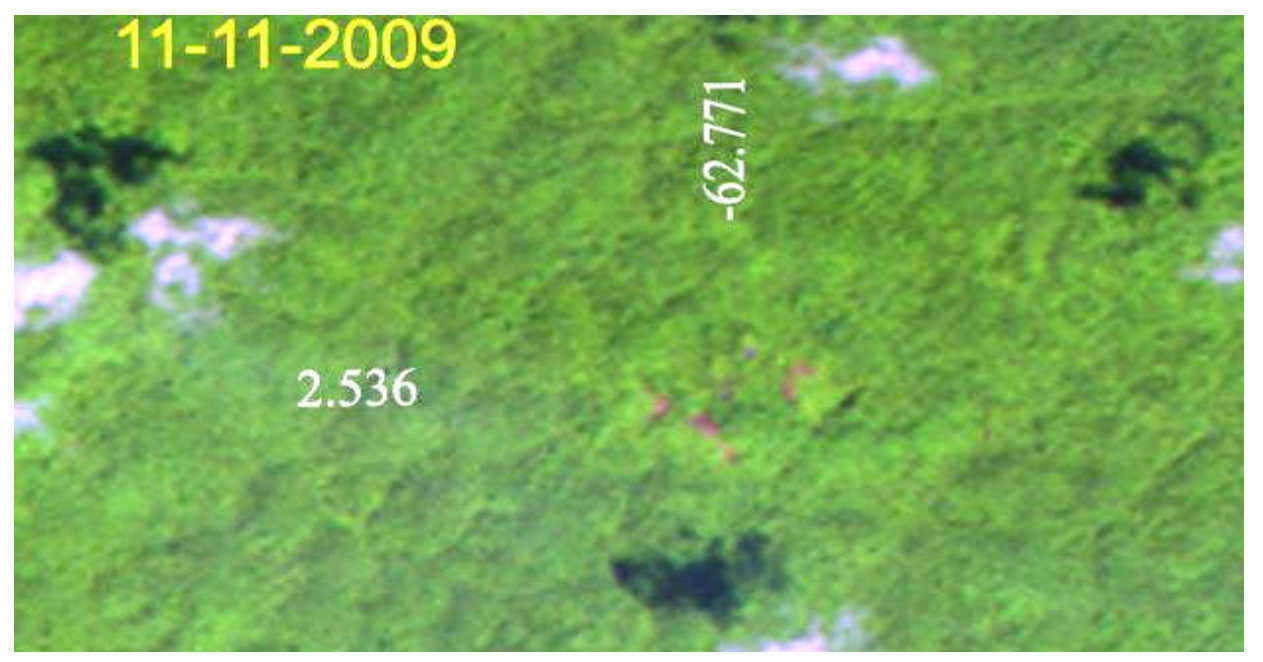

Figura 37 Imagem Landsat de 2009, a mesma localidade apresenta as roças já maduras, novas aberturas e uma pequena clareira a nordeste que corresponde à localização da então casa dos Moxihatetema.

A evolução da paisagem indicada nas imagens permite afirmar que a comunidade se instalou nesse local por volta de 2004 abrindo aproximadamente 1.66 hectare, abrindo quase anualmente novas roças. Em 2007 há três clareiras abertas concomitantemente, informação que nos permite especular sobre a organização interna das famílias, pois nos anos seguintes, delas se expandem as novas clareiras, de forma radial à moradia. As mesmas se encontravam maduras em 2011.

A área de clareiras abertas em 2011 é compatível com a de uma comunidade média Yanomami, de cerca de 60 indivíduos, em sete anos de morada e é compatível com a foto divulgada pela International Survival (Iramari 2011), que indica um conjunto habitacional com 15 ou 16 unidades familiares. As clareiras apresentaram roças e trechos em regeneração e estão divididas em quatro blocos, perceptíveis nas imagens de satélite em 2011. A progressão 
da área de roças indica alguma regularidade, com uma área aberta maior em 2008. Entre 2004 e 2011 os Moxihatetema acumularam mais de 30 hectares de clareiras, nem todas ocupadas por roças conforme evidenciado nas fotos divulgadas.

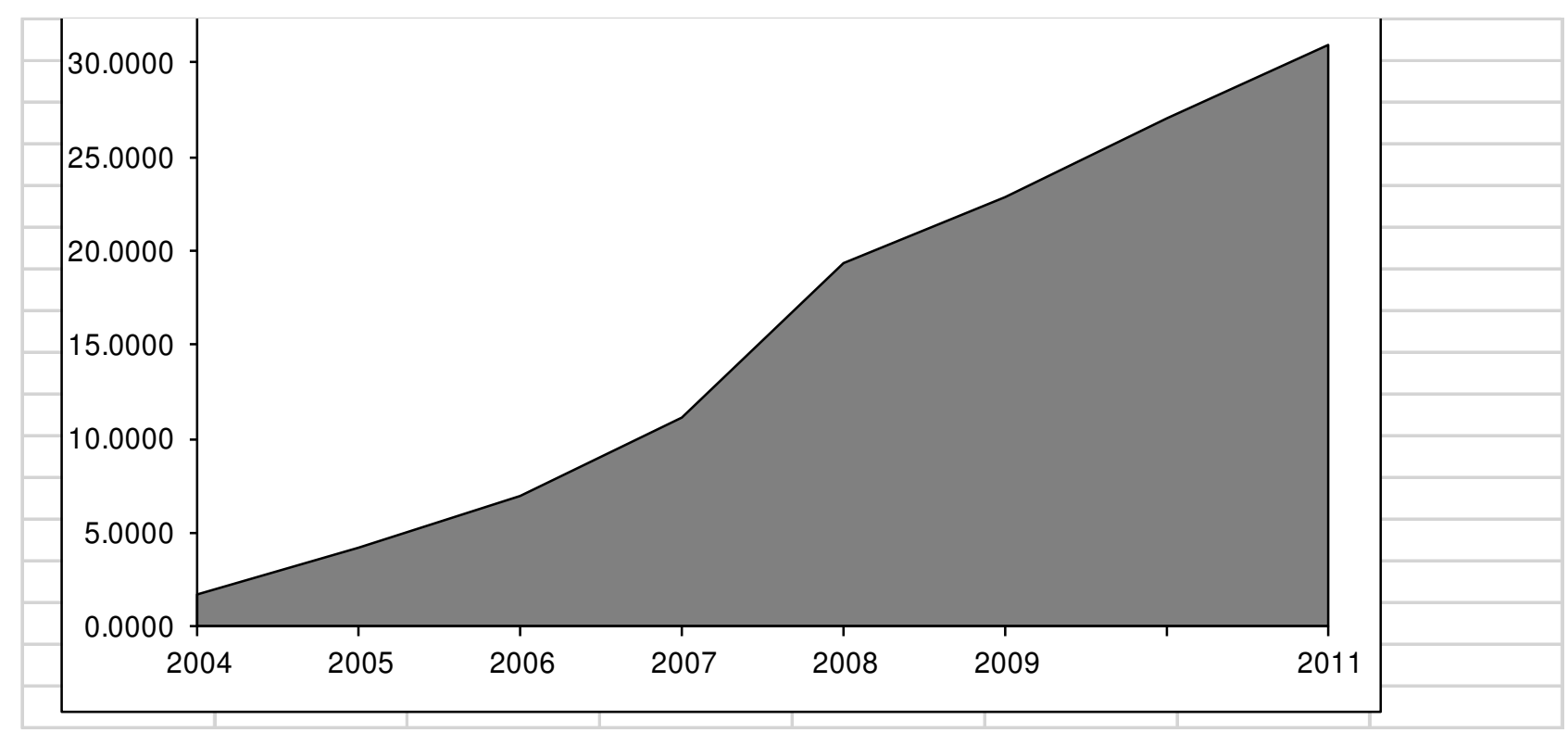

Figura 38: Gráfico com a evolução da área de clareiras durante os anos de moradia na atual região dos Moxihatetema. Não foram analisados dados em 2010, portanto trata-se de uma projeção.

A localização precisa da comunidade permitiu uma análise da situação em relação aos agentes externos, Yanomami e não Yanomami (Fig.39) Dentre os não Yanomami estão os garimpeiros como a maior ameaça de contato e contaminação. A região tem sofrido uma considerável aumento do fluxo de garimpeiros (ver denúncias da população do Papiu em www.Hutukara.org (NILSSON, 2011). Já era antes uma região cobiçada, motivando a manutenção de uma pista de pouso e um posto de vigilância na região da Serra da Estrutura. Dos Yanomami, o grupo mais próximo é o Uxiu, e já sentem seu território ameaçado pela presença dos vizinhos. Isso pode implicar na iminência da organização de expedição de guerra.

A proximidade de garimpo é o fator que mais preocupa: Os Moxihatetema estão a cerca de $27 \mathrm{~km}$ da Pista do Hélio, a $14 \mathrm{~km}$ da Pista da Serra da Estrutura e a $30 \mathrm{~km}$ da Pista do União que dá acesso ao garimpo do Buraco Fundo, todos esses citados pelos Yanomami como dos mais ativos. Tais distâncias não são grandes o suficiente para haver certeza de isolamento, pois é sabido que tanto garimpeiros como Yanomami percorrem distâncias como essas 


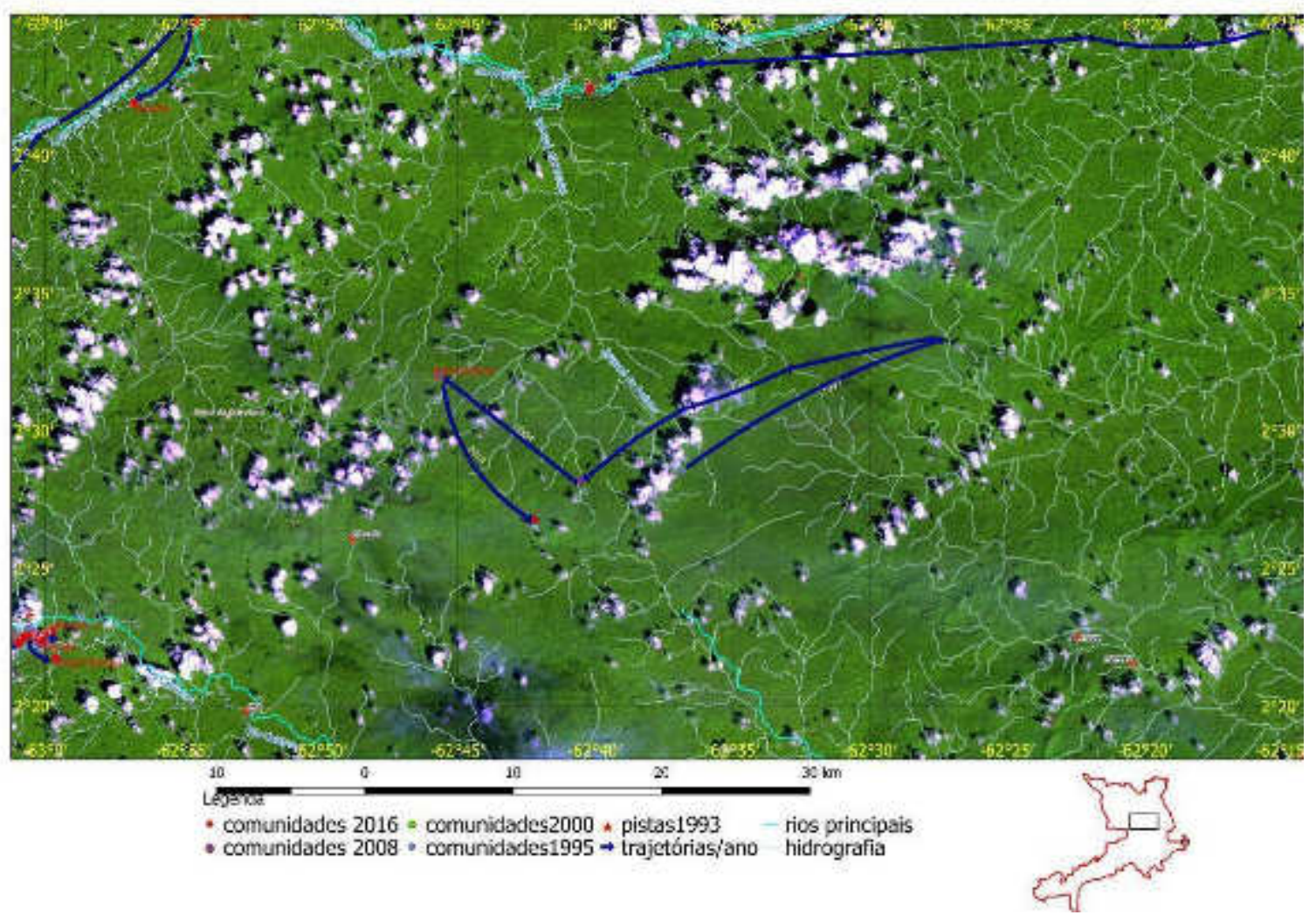

Figura 39: Situação geográfica da comunidade isolada Moxihatetema, em relação a outros grupos Yanomami; não há notícias de relações intercomunitárias deles com nenhum desses grupos vizinhos.

Em 2012, tive oportunidade de percorrer, junto com um grupo em treinamento de servidores da Frente de Proteção Etnoambiental Yanomami, da Funai, um varadouro de mais de $25 \mathrm{~km}$ de extensão, acessada por via fluvial no Apiau. O varadouro permitia acesso de veículos quadriciclos e em seu entorno havia marcas diversas de que a atividade garimpeira ali vem de longa data, facilitada pela rede viária que serve aos assentamentos ao leste da Terra Yanomami (TIY). Essa rota era uma das principais nas décadas de 1980-90, antecedendo as pistas que viabilizaram o tráfego aéreo.

As cavas antigas, em desuso, dão uma dimensão da intensidade de fluxos nessa região, correspondendo ao momento em que não há mais satisfações a dar aos anfitriões, tornados minorias em suas próprias terras. Certa vez, entrevistei um ex-garimpeiro, taxista em Boa Vista e ele relatou como eram as expedições de entrada na TIY por via terrestre, feita por homens armados, e a eventual aparição indígena era tratada a tiros. Isso deve ter marcado o posicionamento dos Moxihatetema, de distanciamento de qualquer relação com os não Yanomami e mesmo com outros grupos Yanomami.

Interpretei 16 imagens Landsat com o objetivo de compreender a mobilidade dos 
Moxihatetema, das quais em 14 foram detectadas alterações na paisagem condizentes com o padrão de abertura de clareiras do grupo. A abertura de novas clareiras e a regeneração das anteriores guardam coerência temporal, evidência de ser a trajetória provável (Tabela 1). Há um encadeamento que aponta para alguns sítios organizados espacialmente com coerência. Mostraremos alguns pontos dessa trajetória e a expansão da área, quando não há movimentação. A área aberta em cada situação indica um aumento da extensão aberta a cada novo sítio, podendo fornecer informações sobre sua demanda alimentar, e situação demográfica, do número de indivíduos em condições de produzir roças.

Tabela 2: Imagens utilizadas e informações de clareiras aferidas: coordenadas em graus decimais e área aberta e acumulada em cada local. Sublinhamos, na coluna 'total area' onde houve movimentação da residência

\begin{tabular}{|c|c|c|c|c|c|c|c|c|}
\hline \multirow[b]{2}{*}{ Date } & \multicolumn{8}{|c|}{ Cloud cover } \\
\hline & Q1 & Q2 & Q3 & Q4 & $X$ & $Y$ & area(ha) & total area \\
\hline 19/12/1988 & 30 & 0 & 30 & 0 & - & - & & \\
\hline 21/10/1991 & 0 & 0 & 5 & 5 & - & - & & \\
\hline 13/05/1995 & 0 & 30 & 5 & 45 & 2.482 & -62.628 & 7.11 & 7.11 \\
\hline 30/06/1995 & 50 & 20 & 80 & 70 & 2.482 & -62.628 & - & 7.11 \\
\hline 10/11/1997 & 30 & 15 & 50 & 5 & 2.551 & -62.455 & 3.97 & $\overline{3.97}$ \\
\hline 26/09/1998 & 20 & 20 & 20 & 20 & 2.551 & -62.455 & 3.48 & 7.45 \\
\hline 01/02/1999 & 30 & 10 & 20 & 20 & 2.551 & -62.455 & 0.55 & 8 \\
\hline $13 / 11 / 2001$ & 10 & 10 & 10 & 10 & 2.47 & -62.68 & 1.12 & 1.12 \\
\hline 08/01/2002 & 20 & 60 & 10 & 10 & 2.47 & -62.68 & 4.79 & 5.91 \\
\hline 24/09/2003 & 20 & 10 & 20 & 10 & 2.47 & -62.68 & 3.92 & 9.83 \\
\hline $15 / 12 / 2004$ & 10 & 0 & 10 & 10 & 2.536 & -62.771 & 1.66 & $\overline{1.66}$ \\
\hline 29/09/2005 & 10 & 10 & 10 & 10 & 2.536 & -62.771 & 2.51 & 4.17 \\
\hline 09/04/2006 & 15 & 15 & 15 & 40 & 2.536 & -62.771 & 2.71 & 6.89 \\
\hline 07/02/2007 & 10 & 10 & 5 & 5 & 2.536 & -62.771 & 4.19 & 11.07 \\
\hline $23 / 10 / 2008$ & 10 & 10 & 10 & 10 & 2.536 & -62.771 & 8.33 & 19.40 \\
\hline $11 / 11 / 2009$ & 10 & 20 & 20 & 20 & 2.536 & -62.771 & 3.46 & 22.86 \\
\hline $29 / 08 / 2011$ & 30 & 40 & 20 & 40 & 2.536 & -62.771 & 8.08 & 30.94 \\
\hline
\end{tabular}

Há um ponto confirmado para o ano de 1994, era de conhecimento da Funai e de parceiros dos Yanomami a presença de sua residência nas coordenadas apontadas acima. Em 1995 o grupo abriu clareiras em uma região das cabeceiras do Igarapé Prainha, afluente do Rio Mucajaí na altura da atual comunidade Uxiu, que se originou do Alto Mucajaí. Dessa região, a cerca de $15 \mathrm{~km}$ a leste, observou-se aberturas a partir de 1997, em afluentes do Rio Jacaré, que desemboca no Rio Mucajaí na altura do PIN Baixo Mucajaí, vindo de oeste, ou seja do interior da Terra Yanomami, no interflúvio de vários rios dessa região: o Apiau, o Ajarani nascem ali, e também igarapés menores, o Uxiu/ Prainha, possuem cabeceiras vizinhas com o Jacaré e ambos afluentes do Mucajaí; e próximo está o cotovelo onde o Rio Catrimani faz seu desvio ao sul. Esse curso d'água é utilizado desde muito tempo como porta de entrada fluvial para garimpeiros, o que surpreende a sobrevivência do grupo nas 
proximidades.

Foi identificada a localidade em que se encontravam no período entre 2001 e 2003. Nesse período as novas aberturas resultaram numa clareira final de quase dez hectares, As clareiras do período de morada imediatamente anterior (1997-1999) estão a leste dessas, o que indica um deslocamento para o oeste.

No intervalo seguinte, ocorrem novas aberturas próximas à clareira de 1995 , pouco a oeste desta, entre 2001 e 2003, chegando a totalizar 9.8 hectares abertos em 2003, quando então são abandonadas e o grupo alcança onde permanecerá de 2004 a 2013. Nesse período de 2001-2003, o grupo ocupou uma borda de encosta de serra, local em que geralmente há maior acúmulo de solo. Foram abertas tres clareiras separadas entre si. O conjunto das clareiras abertas em todo o período em que se detectou alguma alteração na paisagem por esse grupo indica certa continuidade histórica de uma população em crescimento. A trajetória do grupo no intervalo total auferiu uma distância de cerca de $55 \mathrm{~km}$ (Tabela 2). A identificação em momentos anteriores torna-se difícil pela profusão de garimpos, pistas de pouso e clareiras que dominaram a região entre 1988 e 1995.

Tabela 3: distâncias entre os sítios ocupados em diferentes períodos pelos Moxihatetema

\begin{tabular}{lllllll}
\hline ano & grupo & $\operatorname{dist}(\mathrm{m})$ & $\mathrm{Y} 1$ & $\mathrm{X} 1$ & $\mathrm{Y} 2$ & $\mathrm{X} 2$ \\
\hline 1997 & Moxihatetema & 18.84 & 2.482 & -62.628 & 2.551 & -62.455 \\
2000 & Moxihatetema & 25.62 & 2.551 & -62.455 & 2.47 & -62.68 \\
2004 & Moxihatetema & 11.19 & 2.47 & -62.68 & 2.536 & -62.771 \\
\hline
\end{tabular}

O método de sensoriamento remoto utilizado nesse trabalho soma-se ao esforço na garantia de direitos, ao referendar sua existência sem a necessidade de contato físico, respeitando a sua vontade de não ser encontrado. Traz esse perigo, também, por viabilizar um eventual contato forçado; Não é preocupação vã, uma vez que houve artigo defendendo tal intervenção (WALKER; HILL, 2015) apesar de haver a atribuição de sua proteção pela Funai, enquanto órgão oficial de Estado; tem constituído grande vitória nesse pequeno setor da política pública indigenista, de o não contato fazer parte das técnicas de proteção pela instituição (VAZ; BALTHAZAR, 2013; VAZ; COELHO et al., 2013).

Não ter localização definida, ou nosso equivalente, não ter endereço: uma rebeldia espacial a garantir esse direito à diferença, a resistência em ser contatado; isso, considerando a provável experiência deles conosco, sua decisão é por temerem esse aprisionamento, sem 
mesmo ter noção do que é a empresa colonial mundial, sabem-na perigosa, capaz de desafiar a estabilidade das coisas.

Do ponto de vista das representações que nossa sociedade faz dos resistentes ao contato, representam um fato raro, valorizado enquanto informação. Enfeitado ainda com sistemáticas visões exotizantes, de um lado, ou de uma imagem não tão idílica, de pobreza, de escassez, de ignorância, de privações, posto como contraste ao 'conforto' alcançado pelas massas urbanas. Mas há outras características associadas à sua residual existência nos dias de hoje, quando vemos o planeta organizado num sistema de mercado e por todas as consequências disso; de fato enquanto ícone, um povo isolado alimenta a alma dos cidadãos metropolitanos, cujas relações, sempre mediadas pelo Estado, suas leis e seu poder de polícia, tem na imagem que fazem desses povos um oposto radical, a se recusar a esse encontro, a se render ao modo de vida dessa alteridade dominante.

Uma rápida consulta ao 'Google' revelou 8400 locais na internet onde o termo Moxihatetema, de origem Yanomami, apareceu. Objeto de matéria fotográfica na Nat Geo, ao mesmo tempo em que divulgado pela organização de Direitos Humanos Survival International, por esse outro lado, permitiu uma visibilidade com o objetivo de defesa, na condição de ameaçados pela alarmante invasão garimpeira. Mas o que seria essa defesa? Adentrar a selva para medir suas pressões arteriais (arriscando a tirá-los da frágil bolha imunológica frente a uma potencial crise epidemiológica e assim contaminá-los, antes mesmo de lhes oferecer imunidade), ou garantir o direito ao não contato, enquanto efetua a retirada dos invasores garimpeiros, bem como estimula uma compreensão maior de seus vizinhos Yanomami, Tais como os Uxiu, à beira do Mucajaí, os Yanomami de leste, em geral (Baixo e Alto Mucajaí, Apiau, Ajarani e habitantes do Catrimani, Alto e médio) sobre a importância em garantir as condições sanitárias das florestas que habitam?

É preocupante também as consequências da divulgação da existência de isolados, uma vez que há ainda hoje uma procura por fenômenos pouco usuais, de exotismo das sociedades indígenas contemporâneas, podendo levar a uma corrida por imagens e até mesmo ao contato. A controvérsia em torno do contato forçado levantada por Walker e Hill assume seu lado nefasto, condenável do ponto de vista ético, apoiado em informações pouco confiáveis sobre as articulações do movimento indígena com seus apoiadores e com setores dentro da Funai e do Ministério da Saúde (RODRIGUES, 2014), que fundamentam sua atitude em um histórico 
de experiência onde, a despeito da boa intenção, levou a óbito percentuais consideráveis das sociedades contatadas (RODRIGUES, 2014:13) vem a ser simbólico da postura de colonialismo, impositora já tradicional à sua sociedade de Estado, intervencionista em países aos quais julga ter direito de ingerência.

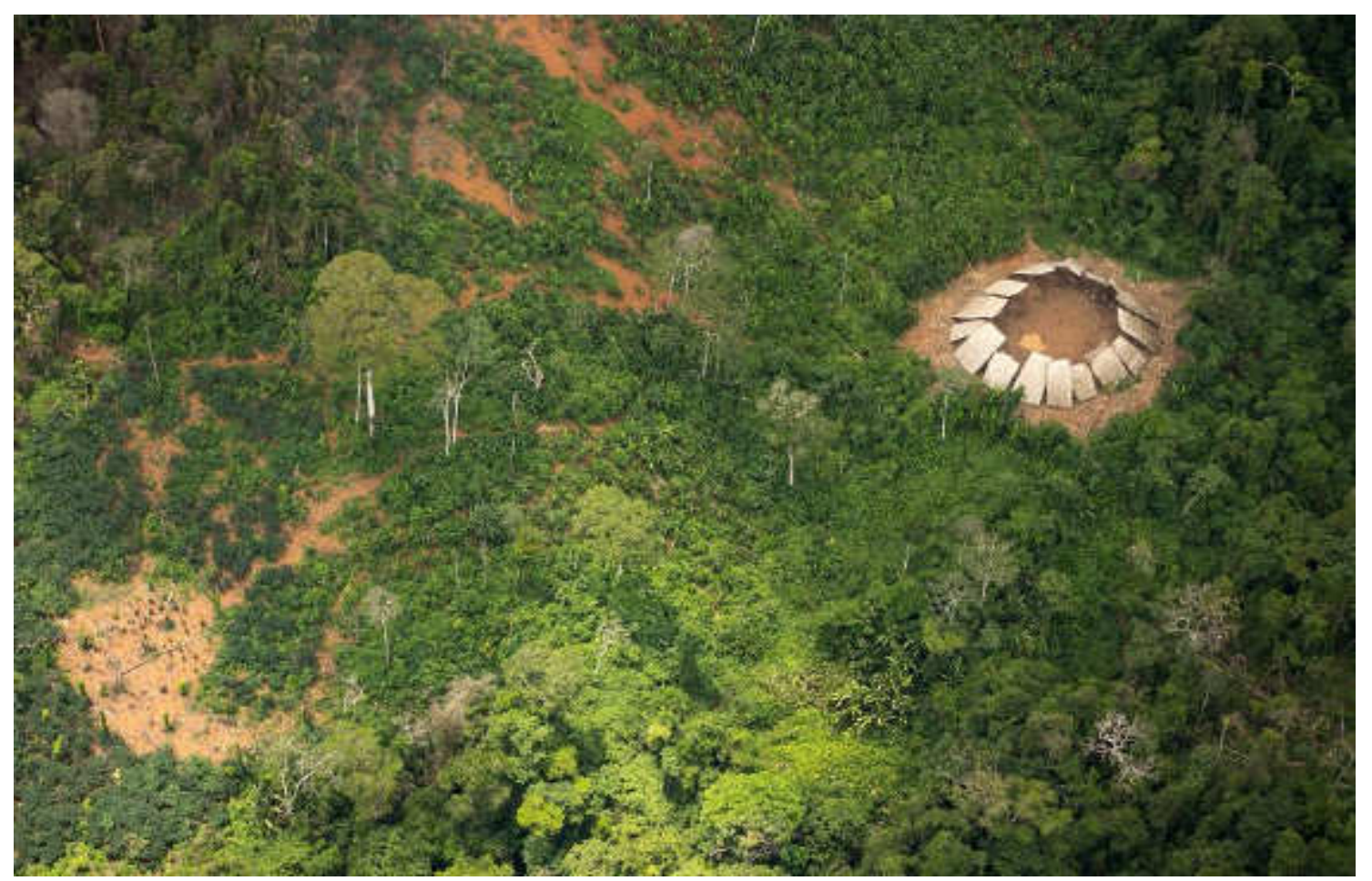

Figura 40: foto aérea oblíqua da casa dos Moxihatetemapë, em 2016, nas proximidades das cabeceiras do Ig. Prainha, Uxiora; foto de Guilherme Gnipper, 2016/Hutukara.

A foto de Guilherme Gnipper, 2016 (Figura 40) num esforço conjunto da Hutukara com a Funai, mostrando expoentes da comunidade, ao ser divulgada, teve papel importante nessa controvérsia, ao reavistar residentes, pois um dos argumentos era a possibilidade de terem até se mudado dali, desde o primeiro avistamento cuja filmagem fora realizada por Morzaniel framari,Yanomami participante da Hutukara. É simbólico as primeiras imagens registradas serem de um cinegrafista Yanomami. Partindo de suas informações, a nova posição dos Moxihatetemapë foi estudada aqui por imagens de satélites, demonstrando a evolução da clareira, desde as três primeiras aberturas em 2014, quando 'desapareceram' da posição conhecida em 2011. A clareira tornou-se de tamanho similar à anterior, indicando a saúde alimentar do grupo. Também a configuração dessas novas clareiras perante a toda trajetória do grupo merece reflexão, como veremos.

Comecemos adicionando a informação de que, no sobrevôo, não observou nenhum sinal de ferramentas ou outro utensílio alienígena. E analisemos o que a foto parcial da clareira mostra de uma roça desse período de 2014 a 2016: a plantação de bananeiras (Musa sp.) é a 
principal ocupação visível, numa área de encostas suaves, não completamente desmatadas; em congruência com as ferramentas disponíveis, presume-se, as árvores mais altas permanecem, e sobreviveram aos fogos que inauguraram a clareira. Há novas aberturas, ainda descobertas de plantação; percebem-se espaços de caminhar, outros cultivos de menor escala, onde presume-se, encontram-se tubérculos como as dioscoriaceas (carás), Manihot (mandiocas) e Ipomeas (batatas doces), além de outras de utilidades diversas, flechais (xikawa), urucum, pupunheiras; próximo à residência já há área iniciando regeneração onde se encontram palmeiras, lianas, mas havendo espaço para caminhos e terreiros. O prognóstico de como será a paisagem anos após o abandono se apresenta à imaginação especulativa, com as grandes árvores permanecendo, outras crescendo rapidamente, e nos subbosques uma profusão de palmeiras com alguns remanescentes dos cultivares nas roças, imersas na fisionomia já florestal.
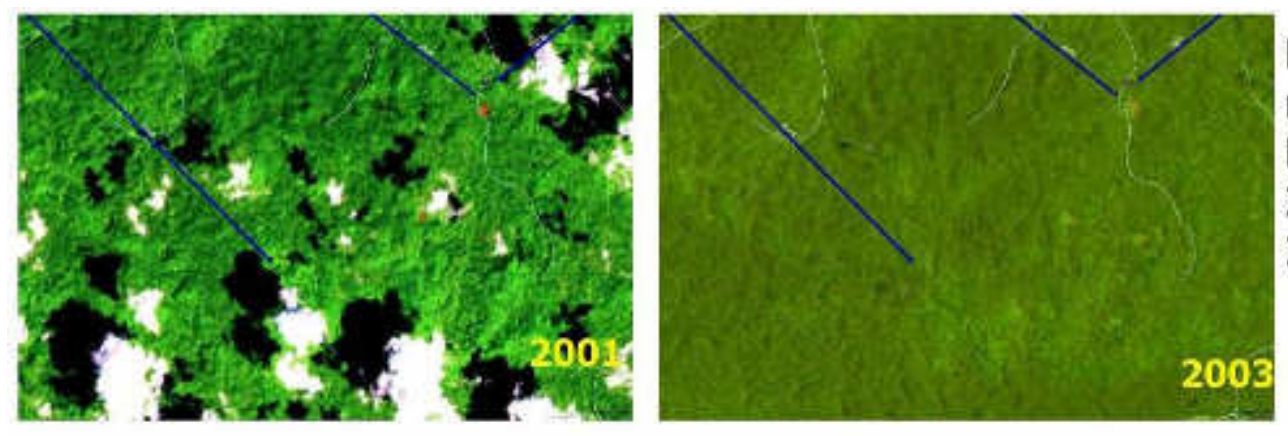

Moxihatetema no Igarapé Prainha 2001-2003 2014-2017
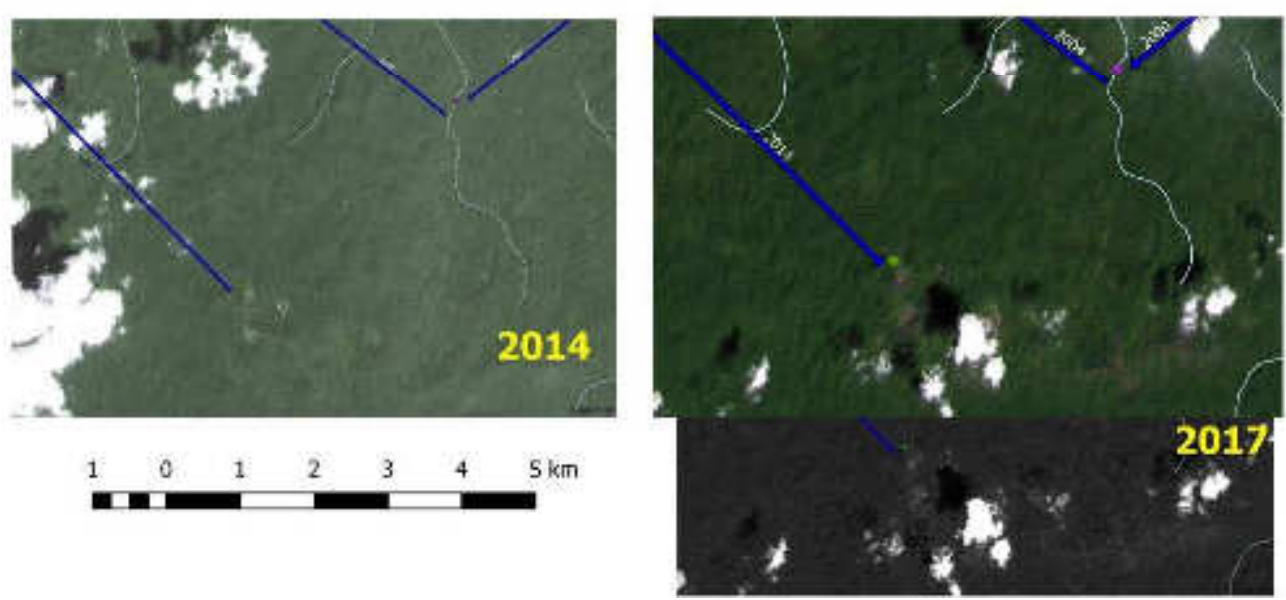

Legenda comunidades

- 2016

- 2008

- 2000

- 1995

$\rightarrow$ percursoiano hidrografla

Figura 41 Localização dos Moxihatetemapë em 2000 a 2004(Landsat 5TM) e de 2014 a 2017(Landsat 8 com banda 8). Na imagem de 2001, a direita e acima (nordeste) notamos um ponto vermelho, indicando abertura de clareira recente, na imagem de 2003 essa mesma clareira encontra-se madura, com roças. Na imagem de 2014, há três pequenas clareiras, indicando a nova ocupação, situação que se repete na imagem de 2017; embora com nuvens é possível perceber as aberturas e até a formação oval / circular das residências nanahi, na imagem em preto e branco, de maior resolução (15metros). A distância dentre as posições é de $3 \mathrm{~km}$ aproximadamente. As linhas em azul apontam as direções de onde vieram, com as datas prováveis.

A posição aferida da nova habitação dos Moxihatetemapë, já próximos ao Igarapé Prainha (Figura 41), indica uma distância de 3,5km de uma velha habitação deles mesmos, nas margens desse referido igarapé em suas cabeceiras; eles habitaram esse local entre 2001 e 
2003, antes de se moverem às cabeceiras do Igarapé Uxiu, onde foram reencontrados e filmados (2011). As novas clareiras e seu crescimento indicam uma rápida expansão, entre 2014 e 2017, e a casa, com 16 segmentos de morada, indica uma população maior que a anterior. A saúde do grupo parece não estar afetada, e sua estratégia de manter distância tem funcionado.

Um trabalho que busque compreender as intencionalidades de uma dada população sem no entanto ter contato com essa mesma, terá na imaginação especulativa uma necessária aliada, coerente ao que foi auferido nos resultados. A resistência do grupo em ser contatado não é acidente, e pode ser consequência de as primeiras impressões da alteridade terem sido marcadas pela violência, pois estavam numa das principais rotas de entrada de fluxos de garimpeiros terrestres e fluviais, pelo Apiau.

A mobilidade dos Moxihatetemapë, evidenciada nesse trabalho, além de indicar a recusa ao contato pode ser analisada como expressão de um grupo sob a tensão da iminência de um encontro não amistoso. Mas parece manter os padrões que encontrei nos outros estudos de caso, onde a referência de uma clareira antiga parece ser um ponto a ser buscado, no caso as moradias do grupo no início do milênio foram escolhidas para, a uma certa distância, retomar antigas florestas de ocupação e uso. Do ponto de vista geográfico, as florestas em regeneração de suas antigas roças estão no raio de cinco quilômetros, estabelecido arbitrariamente como o primeiro círculo de uso da floresta (ALBERT 1985), aquele em que se alcança a pé, para retorno no mesmo dia, sem pernoite, e delimita o uso mais intenso, tal como as caçadas cotidianas ramahuu.

Pela similaridade com outros casos, a pendularidade com clareiras de antigas moradias, num intervalo de cerca de uma década, sugere a demonstração de uma inteligência espacial, relacionada às velhas capoeiras, áreas de regeneração e o que elas podem produzir de modificações no seu entorno. Sabe-se que tais capoeiras são florestas com características próprias, quanto a espécies presentes, bem quanto ao crescimento e floração e frutificação mais rápidos em relação à floresta de maneira geral. Também há o fato de os Moxihatetema terem aí um território conhecido familiar, quanto ao conhecimento de acesso a recursos específicos. A condição das mediações sobrenaturais com os xapiripë, a contar pelo que se conhece de outros grupos, deve ser considerada, nas escolhas de sítio de moradia 
A concepção de doença e morte, imputada a outro grupo rival (ALBERT 1985:311-12) leva à formação de alianças e rivalidades na organização política Yanomami. Os Moxihatetema, por provavelmente estarem sem aliados próximos na vizinhança, parecem fugir à regra: salvo algum possível aliado distante na Venezuela, parece estar em uma posição anômala de franco isolamento de outras comunidades, caso inesperado no universo conhecido Yanomami. Sempre se preconizou a inevitabilidade da participação na rede de relações intercomunitárias, para garantir casamentos, acesso a utensílios e outros fluxos.

Uma resposta especulativa, considerando a impermanência como regra num horizonte de uma década ou mais, é que a congregação atual com cerca de uma centena de pessoas, seja justamente resultado da união de grupos até então distintos, visto que encontramos clareiras separadas entre si por florestas. Pelo momento atual, essa congregação poderia estar no processo de relacionamento, e estaríamos vendo um ponto no tempo de uma situação, podendo esse retomar formas imprevisíveis num futuro.

Mas a condição de não aliança com nenhum dos grupos da vizinhança sugere que podem estar sujeitos à ação bélica de seus vizinhos, caso não haja uma ação de esclarecimento a esses, de não tentarem uma expedição dessa natureza, especialmente o Uxiu, grupo instalado a montante do Alto Mucajaí, sua antiga morada, cerca de $27 \mathrm{~km}$ dos Moxihatetemapë, parece estar disposto a esse tipo de ação, pois já houve notícia de encontros não amistosos entre eles. Os Moxihatetemapë agregam um número de indivíduos maior que uma comunidade média (ALBERT 1992). Isso pode estar relacionado ao crescimento em si, como forma de defesa, uma tendência de resposta a uma ameaça pouco comensurável; se assim for, o crescimento e o sentimento de poder auferido pode levar o grupo a se tornar 'mais valente', sem considerar o tipo de ameaça que lhes aguarda no lado incomunicável do mundo.

Por se tratar de um instrumento à distância, o uso de sensoriamento remoto merece reflexão: oriundo de uma 'visão objetiva' de ciência, e utilizando alta tecnologia, nesse estudo, tal como apresentado até aqui sugere uma transformação do povo em objeto de conhecimento; tratado de maneira objetiva, o mapeamento dos deslocamentos e da atividade de abertura de clareiras para roça e moradia fornece um panorama a mais de análise nesses moldes. No entanto, a arguição teórica aqui tem o objetivo de analisar esse conteúdo geográfico da mobilidade de forma a revelar nela uma intencionalidade, em certa forma, o que fizeram espacialmente de sua própria presença no mundo. Observamos assim o não contato 
enquanto resistência. A conclusão desse estudo que tem como objeto a movimentação espacial dos Moxihatetema é sua condição de sujeitos dessa História.

Seu isolamento, do ponto de vista sanitário e epidemiológico pode significar uma proteção contra doenças e agentes patológicos aos quais provavelmente não possuem imunidade, ao mesmo tempo em que isso significa um frágil equilíbrio passível de ser rompido com um contato malsucedido. A falta de imunidade exige o isolamento como medida de proteção. Já é política corrente dentro da Funai para os isolados que não querem contato promover ações de defesa territorial sem a necessidade do contato, como antes se fazia. Esse tipo de política tem dado resultados no Vale do Javari, que concentra bom número de grupos isolados, que têm sido protegidos sem a necessidade do contato. Geralmente a ruptura do isolamento tem gerado efeitos desastrosos para a maior parte dos casos históricos conhecidos (RIBEIRO 1956). O tema vem sendo aprofundado em um conjunto maior de interessados, incluindo os povos indígenas que os circundam. No caso dos Moxihatetema, a Associação Hutukara participou de eventos com trocas de experiências sobre isolamento voluntário.

Esse grupo, já bastante ameaçado pela situação de presença de garimpo próximo, pela situação de isolamento político em relação a outros Yanomami, demonstra, segundo as imagens, uma vitalidade provavelmente resultante de seu isolamento, que lhe serviu de abrigo em relação à contaminação por microorganismos desconhecidos dos sistemas imunológicos de seus habitantes. Uma rotina de sobrevôos ostensivos poderia lhes indicar ser o momento de se esconderem novamente em outro refúgio, ativando novamente os mecanismos de mobilidade que lhes permitiu a sobrevivência até hoje.

Esse capítulo carece de uma experiência etnográfica mais consistente, um dilema para grupos em isolamento voluntário bem delineado por Peter Gow (2011), em relação aos Mashco. Diante da impossibilidade de efetivamente conversar com eles, do ponto de vista etnográfico, o isolamento voluntário expõe um problema. Ele tenta nesse artigo expor o que se sabe sobre eles, lendo-lhes as intencionalidades. Para tal, parte de fontes históricas, e conhecimentos sobre eles (usar machado de pedra etc). Eu acrescentaria aqui a contribuição do uso de sensoriamento remoto, no caso dos Moxihatetemapë, tentando revelar suas intencionalidades, paradoxalmente. soma-se mais uma fonte, ao contexto já conhecido sobre eles. E corrobora, através desse instrumento, seu desejo de não serem contatados. 


\section{Conclusão}

Os Moxihatetema tiveram recentemente confirmada sua existência, sobrevivência e crescimento demográfico, depois de mais de uma década sem notícia. Tal fato sugere apreensão e atenção, frente às ações que as sociedades de Estados terão a fazer: Geralmente a divulgação de fatos como esse levam a uma corrida de gente em busca de notícias exóticas. Outro motivo de apreensão refere-se à ineficiência (acrescente-se proposital, dados os interesses históricos do poder local) do Estado nacional nas políticas de proteção aos territórios indígenas, diante de mais uma corrida do ouro que assola a Terra Yanomami no Brasil. Embora tenham ficado claras as consequências do primeiro episódio desse tipo, ao final da década de 1980 (PITHAN; CONFALONIERE et al., 1991; ALBERT; GOMEZ, 1997; PITHAN, 2005), os interesses econômicos no Estado de Roraima parecem ser mais fortes do que a pressão pró indigenista na proteção de seus direitos. Urge uma ação clara de coerção à prática de garimpo ilegal, evitando assim um novo genocídio. A existência de um grupo Yanomami em isolamento voluntário reforça a urgência dessas ações. Sua recusa ao contato deve ser levada a sério como comunicação dessa intencionalidade, enquanto povo.

Uma outra violência pode colonizar também as representações que fazemos dos Moxihatetemapë, seu caráter simbólico. Conforme exposto, há uma gama de informações desde que os primeiros sobrevôos forneceram as imagens aéreas e estas ganharam a rede mundial de computadores. Informações na verdade parcas, acrescidas de conjeturações de nossa própria expectativa exotizante dessa condição: alguém desconectado desse nosso modo de ser. Uma violência que pode em breve se transformar em física, como aponta a vontade de certo grupo de pesquisadores em aportar na clareira onde vivem e cravarem seu nome na história de desbravadores do século XXI. Esse troféu simbólico deve ser combatido através de uma representação mais sólida dos Moxihatetemapë, e por extensão aos outros povos resistentes ao contato. A começar pelo combate à visão de povos que se movem pela ausência, repetidamente denunciada nessa tese: não é a escassez e a privação o motor das movimentações desses grupos, mas uma decisão deliberada, não ocasionada pela ignorância mas por uma imagem consistente das alteridades que os cercam. Precisamos reafirmar que eles nos conhecem, e por isso nos evitam.

Como diz Davi, sobre nossos pensamentos confusos, não temos claro o que nos atrai nessas últimas resiliências, nesses que afrontam a relação normativa que temos com o mundo. São eles afinal a demonstrar essa condição como possibilidade, não para fazermos igual mas 
para repensarmos nossa posição como membros das sociedades de Estado. Nossa imagem confusa não nos deixa claramente compreender o fascínio de uma vida guiada pela liberdade de sua própria determinação: seu universo próprio se constitui em outro mundo, a não ter motivos de conversar com o nosso; aceitar a recusa dos Moxihatetemapë como uma decisão coloca a radical conclusão do outro mundo possível, e existente no seio dessa sociedade, a não ver na nossa o caminho a ser seguido.

Com a recusa ao contato, as ações se voltam aos outros, aos vizinhos àqueles que precisam respeitar a decisão do grupo. Assim, o sensoriamento remoto pode servir como uma ferramenta adequada, porém insuficiente, já que as ameaças físicas devem ser afastadas. Através das imagens de satélite, pudemos paradoxalmente oferecer uma visão desse povo como sujeito, numa tentativa de leitura de suas movimentações, admitindo-as como ato de liberdade, determinadas pelas relações dessas pessoas com o mundo em que vivem, e não por algum motivo que queiramos imputar-lhes como causa. Não nos cabe essa questão, a não ser naquilo que nos afeta (ou que os afetamos). Tentar novamente investigar algum determinismo da postura deles é uma violência simbólica. Por um outro lado, colocar as coisas nesses termos nos impõe um limite a nossa presunção de onipotência.

Os Moxihatetemapë permanecem resistentes ao contato, evidenciando uma intencionalidade. Numa forma radical de recusa, os Moxihatetema demonstram ter, na verdade suficiente conhecimento de nossa sociedade, do que lhes espera numa condição pós contato. Um tipo de contato que revela muito mais sobre nosso modo de faze-lo, pois, a maioria de suas versões participa daquilo que vimos fazendo desde 1500, e que os Moxihatetema já vaticinam, à sua maneira.

Enquanto sujeitos de sua própria trajetória, os Moxihatetemapë têm se deslocado por várias vezes, seja como resposta à iminência de um contato indesejado, ou pela sua própria dinâmica e, a contar pelo que sabemos de outras sociedades Yanomami, devem manter seus hekurapë a observarem os sinais do mundo, numa leitura das condições de permanecerem ou seguirem. Negando-se à mistura, ao conhecimeto do outro, diferem-se daqueles estudados por Kelly (2005), numa postura mais radical de recusa, numa atuação belicosa a todos os vizinhos. Devemos ressalvar sobre a belicosidade indígena, frente às barbáries historiadas das sociedades de Estado, ser a guerra Yanomami uma guerra "selvilizada". 


\section{0 Estado como elemento diacrítico: sem ou contra? O não Estado como ausência e como recusa:}

Esse capítulo apresenta reflexões nascidas dos resultados obtidos nos capítulos anteriores, e tem ao seu final a conclusão dessa tese, sobre a mobilidade Yanomami. Trato a mobilidade como recusa de permanecer no posto, de sedentarizar. Conforme descrito nos capítulos anteriores, as decisões de cada grupo devem possuir relação com o modo de pensar dos Yanomami, tal como encontramos elaborado nas palavras de Kopenawa e Albert (2015). Analiso a mobilidade Yanomami e a recusa de constituir poder central sob tal elaboração cosmológica. Busco vínculos e respostas ali, para as lacunas tidas como respostas anteriores sobre os Yanomami.

Nesse trabalho demonstramos intencionalidades associadas à mobilidade, tanto em sua dinâmica própria, como em novos desafios: na relação com o outro em sua terra, como os postos de contato, necessários, fontes de aprendizados. A organização social dos Yanomami, centrada em suas relações intercomunitárias e na sua representação de doença e morte, sempre considerada efeito da ação de outro Yanomami, motiva centralmente as movimentações espaciais de cada grupo, seja pela necessidade de abandonar a lembrança do lugar onde um falecido viveu, seja para se abrigar de um potencial ataque inimigo (vimos isso no Homoxi).

A segunda ausência defendemos haver manejo onde antes se atribuía falta de técnica. Uma análise onde viver é construir paisagens ao agir na floresta, no próprio habitar de cada sujeito. Não mais é possível desconsiderar a presença indígena na construção da paisagem amazônica; os estudos de mobilidade Yanomami oferecem algumas dessas construções, na criação de sistemas sucessionais em um âmbito onde o clímax é a foresta. Após a derrubada e queima, a clareira receberá humanos, mudas e sementes de diversas plantas, e ali viverão, até o mato tomar conta e impedir de aproveitar bem os produtos da sua roça, como eles dirão: "paimirayoma", tornou-se emaranhada, algo assim, confusa. E o "abandono" partindo para área ao lado, significará o crescimento de uma vegetação que floresce rapidamente, produz frutos anualmente alé da proliferação de partes vegetativas, isso torna a capoeira "hutuwaropata" bastante interessante aos animais, muitos dos quais são do interesse para os

Yanomami. Conclui-se assim não haver ausência, mas uma ação consequente; não à toa, um dos movimentos detectados demonstram um movimento pendular, voltando para uma antiga 
roça yanomami, hoje em regeneração. Mas não voltam para a exata mancha onde haviam outrora ocupado, mas nas adjacências dessa localidade.

A terceira ausência é a ausência de poder central organização política onde a possibilidade de centralização é respondida com uma recusa. Nos Yanomami, o detalhado estudo de Bruce Albert, demonstra que a organização social Yanomami pauta-se muito mais pelas alianças intercomunitárias, nas relações de afinidade, do que seguir uma linhagem; essa recusa de um poder patriarcal como uma referência simbólica de um protótipo de Estado, em suas primeiras versões; as alianças intercomunitárias dinamizam uma organização social horizontal, dificultando a instituição de poderes maiores sobre os outros viventes. Tal dinâmica sugere muito mais uma recusa: pela consciência dessa possibilidade da centralização e suas implicações, os Yanomami recusam-na, sabotando-a. Clastres advoga ser a guerra uma das estratégias de recusa; a guerra yanomami é essencialmente descrita por Albert (1985) tanto em suas motivações, relacionadas às causas da morte, segundo os Yanomami, sempre imputada a outro Yanomami, bem como a todo o processo do unokaimou, enquanto ato de matar - purificação ritual por ter tocado em sangue inimigo. E suas relações simbólicas.

O efeito social que ela causa é uma equiparação de poderes, ou um distanciamento quando isso não ocorre, mas nunca a submissão. A guerra yanomami não tem relação com a ideia de guerra colonial, mas uma expressão ritual da raiva e vingança a outro grupo antagônico, num ambiente de franca dispersão e mais esconderijos do que alvos fáceis, por assim dizer, uma guerra 'selvilizada'. Não há também uma polaridade fixa, ela não determina um inimigo constante, mas uma variação dessas inimizades derivada da detecção, via práticas xamânicas, da autoria das intencionalidades nefastas (no Capítulo 6 temos uma descrição).

Assim, convém analisar a síndrome toda, onde a selva, como ambiente da guerra tem agência sobre o modo como ela se dá, socialmente, e esse modo social, representado por uma pulverização da população pela floresta. Nos Yanomami, as relações intercomunitárias de alianças e antagonismos guia, à sua maneira, a uma distribuição dos povos pelas florestas e das florestas pelos povos, tendo na constante negociação xamânica ${ }^{38}$ o equilíbrio do mundo; não se trata de uma apropriação fixa, um território onde tal espaço pertence a um grupo, pois esse pode vir a ser ocupado por outro, quando o novo já tiver se movido. Não se trata,

${ }^{38}$ Os xamas, xapiri são protagonistas das descobertas, nunca ou raramente declaradas das inimizades e malefícios realizados; assim, seu trabalho tem grande importância nos conflitos e alianças de um dado grupo. 
tampouco de uma ausência de relação com um passado, pois vimos as pendularidades como movimentos comuns a vários dos grupos estudados. No processo de familiarização com as florestas, os grupos experienciam uma relação com outros grupos, não havendo apego ao espaço ocupado e nem havendo descompromisso. Há sobreposições territoriais entre grupos, intercruzando-se em seus usos e apropriações.

A leitura da paisagem se faz pelos vestígios, por evidências nos caminhos, rastros, pegadas; pela leitura xamânica das intencionalidades diversas. A concepção onde atuam os mais variados xapiripë, entidades mágicas na forma de homúnculos enfeitados com base em sua alter-identidade animal, que influenciam esse equilíbrio do mundo nos mais variados diagnósticos; bem como nossa condição pré-individuação de estarmos ligados a um animal, ainda na forma humana presente, nos coloca como condicionante um mundo severamente mais instável que a physis tal como a consideramos em nossa ciência. Olhar para um animal tendo como ótica as duas concepções condiciona o relacionamento em caminhos fundamentalmente distintos: se somos animais, os animais que nós caçamos também somos nós; a nossa finitude e impermanência, vivendo apenas um átimo desse ser chamado Urihi (podemos considera-lo diferente de 'floresta', tal como um napë a o consideraria, pelas implicações), que na consciência dos seus denominadores, trata-se de um ser vivo, uma entidade composta de outras entidades, implicando que de todas essas entidades juntas, sua existência depende. Nessa composição cosmopolítica, onde a Urihinari (a entidade-floresta), é mais uma entidade, mas igualmente resultante desse coletivo que a forma, a atuação dos xapiripë, dos Yanomami treinados para fazer a leitura diagnóstica que resultará estável para os seus co-residentes yahitheripë. Davi tira conclusões sobre a terra-floresta, sobre a florestaespírito e sobre o espírito da floresta, em a queda do céu: explica aos napëpë, ignorantes da cosmologia dominante, e oferece uma explicação do comportamento tão pouco afeito a atentar para a delicadeza desse equilíbrio:

O pensamento dos xamãs se estende por toda parte, debaixo da terra e das águas, para além do céu e nas regiões mais distantes da floresta e além dela. Eles conhecem as inumeráveis palavras desses lugares e as de todos os seres do primeiro tempo. É por isso que amam a floresta e querem tanto defende-la. É impossível para os grandes homens brancos conhecer a floresta como nós. Por isso não se incomodam em destruí-la. Dizem a si mesmos que ela cresceu sozinha e cobre o solo a toa. Com certeza devem pensar que está morta. Ela só parece estar quieta e nunca mudar porque os xapiri a protegem, empurrando para longe o vendaval yariporari, que flecha com raiva as árvores, e o ser do caos xiwaripo. A floresta está viva, e é daí que vem sua beleza; ela parece sempre nova e úmida, não é? Se não fosse assim suas árvores não seriam cobertas de folhas. Não poderiam mais crescer nem dar aos humanos e animais de caça os frutos de que se alimentam. Nada poderia nascer em nossas roças. Se a floresta estivesse morta nós também estaríamos tanto quanto ela! Os brancos talvez não ouçam seus lamentos, mas ela sente 
dor, como os humanos. Suas grandes árvores gemem quando caem e ela chora de sofrimento quando é queimada.

Excerptos do capitulo "Espírito da floresta” em A queda do céu (2016) p.468.

O povo da mercadoria, tal como Davi define nossa sociedade, explica bem o nosso determinante, em congruência com a 'cargo cult' dos nativos, definindo nosso modo de vida, num exercício de antropologia reversa, ironizando o título 'road belong to cargo' de Peter Lawrence (WAGNER, 1981 p. 67). Independente de essa definição comportar maior ou menor sentido para cada indivíduo, torna-se um imperativo no nosso modo de pensar, mesmo quando determinados a defender a natureza, a combater sua destruição, é através de uma valoração que perpassa pela lógica da mercadoria; a questão ambiental a biologia da conservação, todos atribuem valores àquilo que buscam conservar, mecanismos como 'serviços ambientais', a delimitação de unidades de conservação passam pelo sentido de gestão cuja linguagem não difere da dos negócios usuais, que regem o mundo capitalista, embora os efeitos sejam mais em acordo com os povos indígenas, quanto à proteção da natureza, o são por motivos e modos distintos; por isso, há uma cisão teórica entre o conservacionismo e o indigenismo de alguma forma obviada (em geral por um terceiro, os povos indígenas, mantendo esses importantes aliados eventuais). Como exposto no capítulo I, Bruce (2002) analisa a percepção de Davi em obter de si a imagem necessária para convencer os seres de outro mundo, cuja lógica foi aos poucos tornando-se inteligíveis. Sem recurso à mentira, é a exata autenticidade da luta indígena que convence esses poucos parceiros qualificados que os povos indígenas conquistam em nossa sociedade. Mas Davi igualmente expressa uma decepção pela dificuldade de mudar a sintonia de pensamento do povo da mercadoria. Seu cegamento pelo mundo material, diz ele, e suas representações em papel (uma tentativa de materialização do pensamento), o impedem de perceber a floresta viva, os sentidos de raiva, de emoções implícitos nessa sentença.

A lógica da mercadoria a dominar nosso pensamento é oriunda da divisão de natureza e cultura, que a sustenta, a natureza sendo sempre algo externo e manipulável, de forma a valorar toda terra, ainda que para conservação. Os mecanismos de publicidade da questão ambiental, seus conceitos associados derivam dessa lógica, tais como o desenvolvimento sustentável, a busca de 'alternativas econômicas', ou de 'serviços ambientais', 'mecanismos de compensação financeira', 'danos ambientais', todos se rendem a uma valoração não afetiva, a uma quantificação monetária. 


\section{A não acumulação como parâmetro}

Johanna G Martin (MARTIN, 2016) desenvolve em sua tese algo recorrente em outros estudos de os povos indígenas viverem um pensar metafísico, uma administração das energias do mundo, Taylor (TAYLOR, 1996) conta sobre o empenho com as ações xamânicas pelos Sanuma como motivo para seu estudo. Martin (2016) também nos apresenta essa passagem:

"A notable example among the Yanomami is that presented by Chiappino (1995), who argues that the Yanomami master a kind of bioenergetics" in their control of a vital principle or pufi. While the pei pufi described by Lizot and by Albert has the connotation of a body component ${ }^{39}$ (preceded as it is by the incorporant particle -pei), what Chiappino calls pufi is a vital principle that is responsible for the dynamism of existing beings and the order of the cosmos." (Martin, 2016 p.172).

Parece surpreendente, nos dias de hoje um povo estar mais atento à cosmologia, movimentar-se mais em função das interações xamânicas com o mundo. Não há pretensão outra que administrar os seres cosmológicos naquilo que interagem pela estabilidade do mundo.

Do ponto de vista do staff político atual, adepto ao imperativo da acumulação, o possível maior pecado dos povos indígenas seja a característica diacrítica da não acumulação. Fiel ao sentido bioclimático da Amazônia, que desfaz rapidamente os materiais, nem as coisas pessoais são longevas, sendo constantemente renovadas. A não acumulação demonstra ser ponto de inconformismo por parte de grande contingente na nossa sociedade nacional. $\mathrm{O}$ fato de os indígenas não serem "produtivos, em termos de acumulação" já foi argumento e objeto de ações de ministro, quando declara que deve haver um critério "custo-benefício" para o Brasil na demarcação de terras indígenas. Um ministro, confessando sua ruptura de princípios de proteção às sociedades indígenas, de autodeterminação, baseado em um conceito de sua sociedade, tem um projeto para a sociedade indígena, que ele tentou chamar de integração, depois organização social sem reconhecer que os povos indígenas já possuem sua própria organização social, e isso lhes é garantido pelo Artigo 231 da CF (BRASIL 1988). Não acumular, parece ser o principal pecado ao qual os indígenas não podem incorrer, segundo o enunciado oriundo da economia napëpë, daí deriva o não ser produtivo, “os índios não fazem nada..." ouvimos com frequência. Esse é obviamente falso em todas experiências, esse povo trabalha muito. A lida com roça, com a construção de uma casa, com a obtenção de alimento em toda sua diversidade. Não há dúvida que a sociedade indígena é produtiva. É produtiva de

39 Discordo quanto a conotação atribuída a Bruce, na tese, pihi é um dos componentes da pessoa, não necessariamente corporal; mas não altera o conteúdo exposto por Johanna Goncalves Martin. 
si mesma e toda a malha de relações multiespécies que se pratica, e que estamos longe de compreende-la em sua complexidade; mas não é disso que se trata.

Os interesses econômicos têm sido o principal atrito com povos indígenas, motor da sociedade e este utiliza a hegemonia no Estado, por empresários e representantes para impor toda forma de exploração econômica da terra indígena. Viver fora do estatuto imperativo da acumulação já é uma forma de contraponto. Não a toa os modos de ocupação são detectáveis nas imagens. Embora os diversos exemplos desse senso comum em relação ao índio devam ser entendidos como nossa intenção de prescrever-lhes o que devem ser, as difíceis estratégias dos povos indígenas seguem curso de resistência, dispostos a mudarem, aprenderem com o processo, incorporarem os saberes (os modos) alienígenas, para defenderem o direito de viverem ao seu modo.

Em Boa Vista, as demandas materiais indígenas movimentaram uma parte da economia da cidade, um local cuja economia tenta se diversificar por ser uma capital, mas o emprego ainda é uma demanda. O sistema médico emprega. Os Yanomami adquirem dinheiro nos pequenos trabalhos auxiliares que viabilizam o atendimento indígena. $\mathrm{O}$ consumo de redes, roupas, panelas ferramentas, lanternas e por parte de alguns também relógios, gravadores e recentemente, celulares, movimentam o comércio na cidade. Os gravadores serviram também ao enriquecimento de repertórios interculturais com os quais os Yanomami tateavam os sons da nossa sociedade. Aulas, musicas, discursos yanomami, eram gravados por interesse de uma geração de professores. Viam em seus assessores, alguns desses usos, o interesse em registrar, reouvir, absorver melhor. O comércio era paisagem etnográfica frequente dos jovens yanomami escolhidos para serem prepostos com os estrangeiros napëpë. Há uma demanda pela interação econômica e a obtenção de recurso que viabilize o acesso a produtos do mercado, na condição de utensílios.

Num panorama 'business as usual' (negócios, como sempre), isso seria tratado como a exploração econômica em sua condição mais colonial de contrata-los para serviço pesado de fornecer uma dada matéria prima de baixo valor e bruta, sem mesmo nenhuma agregação pela origem do produto comercializado.

Numa outra perspectiva, uma alternativa de relação ao mercado com base em outro ator, a se tornar parceiro, o das pessoas cosmopolitas, no sentido de virem da metrópole, de 
centros urbanos em contato com a multiculturalidade hodierna, e que valorizam produtos de origem indígena. Vários exemplos poderiam ser dados de criação de produtos, bem representados em mercados específicos, e remunerados conscientes de sua origem e agregados valores mais simbólicos. A dieta, o consumo de um produto, o cogumelo extraído de roças sanuma vem sendo comercializado e aberto ao mundo por Alex Atala, representante da gastronomia internacional de alto nível.

Os cogumelos aparecem em roças antigas, associadas à decomposição de troncos caídos desde a derrubada, mesmo depois de encerrado o ciclo propriamente agrícola, mas não encerrando a produção da área de mais uma miríade de produtos, dentre pequenos animais, mais tarde grandes, mas também colubriniformes (hoya, etc), as larvas do caule de rihuarisi (Jacaratia digitata.Caricacea), conhecidas por lihuari moku (poderia ser traduzido como frutos de lihuari, embora se trate de larvas de besouros gigantes que habitam seu tronco e são consumidas).

Ainda é cedo pensar nas implicações do comércio de cogumelo sanöma, mas cabe discutir aqui que as iniciativas de encontrar caminhos alternativos à inserção econômica pelas vias de praxe que os entrepostos dos municípios pequenos às saídas das vias de acesso fluvial podem oferecer, mercado de juta, de piaçava, carvão...

Este é certamente um projeto diferenciado, o produto in natura é tratado com seu 'valor cultural agregado', como um conhecimento dos Sanöma. Uma tentativa de aliança com um setor esclarecido da elite paulistana, num nome reconhecido internacionalmente pela alta gastronomia. As alternativas possíveis os tornam menos vulneráveis a propostas insustentáveis. Ou mesmo aos grandes projetos econômicos que prometem recompensa em troca de madeira, minérios. Ha uma disputa que passa pelas escolhas tecnológica e por ofertar opções menos violentas à terra e aos próprios povos que a habitam. Fazer frente a interesses econômicos maiores, as mineradoras ${ }^{40}$, ao agronegócio, enquanto representação, para suprir a uma fragilidade, a da cobiça de produtos do povo da mercadoria, conforme já comentado supra.

Ponto central nessa questão, é o exato fato de o parâmetro ser essa empreitada servir

40 cuja decisão constituinte posterga o debate, hoje o temos nos termos: PL de mineração em terras indígenas X Projeto de. Estatuto do Indio, ambos legislando sobre, com enfoques contrapostos. 
para viabilizar a sua ação não econômica, aquela que não opera com o mercado, sua vida, sua atividade xamânica...tudo aquilo que é incompreendido ou menosprezado pelos defensores do mercado, no governo ou fora, por representar um contraponto útil à humanidade, ao sistema hegemônico, Capital, Estado, disciplinar e mercado. A recusa em submeter-se, tornar-se serviçal de um mercado origina-se de seu envolvimento, de primar pelo seu universo cosmológico de debate com as vontades do mundo, dispendendo mais tempo em atividades xamânicas do que preconizaria o mercado em seu projeto para os outros.

As ações Yanomami nas lidas com o equilíbrio do mundo, se levados mais a sério pela nossa sociedade, poderiam oferecer um contraponto ao nosso modo de ser, permitir uma outra vertente filosófica do debate político, tal como apresentado por Danowski e Viveiros de Castro (DANOWSKI; CASTRO, 2014). Nesse livro, 'uma discussão sobre o fim', a argumentação entretece com as falas indígenas uma outra lógica, aliás muito mais afinada com os pressupostos científicos mais recentes, apontando para as modificações profundas realizadas pela humanidade, podendo tornar o próprio clima do planeta irreversivelmente inóspito à continuidade de nosso desenvolvimento societário industrial. Ao reforçar os alertas xamânicos dos Yanomami, muito bem explicados ao mundo dos não Yanomami na autobiografia de Davi Kopenawa (2015), temos a condição de afirmar essa incompreensível não acumulação e essa defesa intransigente dos equilíbrios entre os seres e entidades do mundo, como uma defesa da paisagem que é cara aos Yanomami e aos povos indígenas amazônicos, cada qual a sua maneira mantendo sua vida e coexistência com a floresta em pé, onde as clareiras de roças são pontos numa matriz florestal; já apontado nos estudos ecológicos sobre os povos indígenas, os resutados demonstram a real proteção da floresta, tal como expresso em Yanomami: "kami Yanomami yamakini urihi yama a noamaï". 'Nós Yanomami protegemos a floresta', numa tradução primária, uma vez que a polissemia de alguns conceitos dificulta compreendermos outras nuances desse enunciado: urihi, floresta, paisagem florestal, mas também terra, território onde se ocupa; noamai é igualmente carregado de outros sentidos: aqui, optei por proteger, mas lembro de ouvir dos yanomami "cuidar" como tradução possível; e proteger, no caso pode também oferecer posições semânticas distintas conforme adotamos significados de urihi: pode ser proteger, no sentido de valorizar a floresta, contra sua destruição, mas pode muito bem significar proteger como resguardar, como te-la para meu uso, evitando que seja apropriado por outros (quando adotamos urihi enquanto território). 
No sentido cosmopolítico maior, em que urihi pode ser adotado como sinonímia de "mundo", a gestão da casa, aquilo que na nossa tradução poderia ser similar a economia, recupera uma postura e um significado mais elaborado de economia, que a muito se perdeu, dada a complexificação da ciência econômica, dos artifícios ali manejados, tornando o mundo, suas bases materiais uma abstração capaz de obviar sua existência; e da profunda transformação à qual essa gestão interpôs ao mundo, desenraizando sua origem etimológica, dado que em economia hoje muito pouco se fala da Terra propriamente, enquanto fator fundamental a ser gerido. O procedimento de inanimação da Terra, em nossa vertente filosófica perde sua agência, parece ter sido fundamental para que possamos não ve-la como capaz de nos informar suas demandas, ao mesmo tempo em que temos no mercado (relação entre homens sobre a matéria por excelência) um ser materializado, capaz de ter desejos, de imperar por modificações nos estatutos entre os homens e de impor medidas de sofrimento à população. A economia, tal como a ouvimos nos jornais tornou-se uma arte de ouvir 'os desejos do mercado', escondendo aí outros imperativos, os sociais, e os ambientais, ou melhor ainda, os socioambientais, já tentando uma abordagem que considere a indissociação entre as sociedades e suas bases materiais, para viabilizar sua análise (LATOUR, 1994).

Os Yanomami chamam a atenção para esse equilíbrio, talvez melhor traduzido em nossa ciência pelas mudanças climáticas, e informam sobre as 'vontades da terra'; no episódio de seca de 2016, o terceiro grande episódio, onde as queimadas se puseram a causar profunda alteração na paisagem, eu ouvi explicações que deixavam claro que Iramari, o verão, veio e não quis ir embora, indignou-se pelas ações dos napëpë. Nesse modo de referir-se a um fenômeno que interpretamos estritamente climático, há uma agência contida, e que precisa ser compreendida: "urihi raa kae yaro thë yopi mahiä̈" "por a floresta sofrer, enfraquecida, o calor extrapolou seu limite', numa tradução livre, mas que assume a intencionalidade da floresta e sua causalidade com o calor excessivo; foi por a floresta sofrer, que a onda de calor se instala (e permite o fogo quase espontâneo de afetar mais ainda a integridade da floresta.). Num equívoco produtivo, num enunciado que não significa a mesma coisa, mas que apontam para a mesma direção, estudos recentes em ecologia tem demonstrado uma nova faceta da Amazônia na questão das mudanças climáticas globais: ela deixa de ser "vilã", pelas emissões de carbono pela queima, para ser "vítima", onde a floresta se fragiliza, tornando-se cada vez mais suscetível ao fogo e a queima praticamente espontânea. Afetada pelas secas radicais, materiais de serapilheiras se tornam inflamáveis mais facilmente, correspondendo à explicação sobre os incêndios que afetaram em 2016 a Bacia do Alto Demini: urihi xiro 
ixirayoma: a floresta queimou por si, (sem que ninguém a incendiasse). Isso corrobora com o que testemunhei em 2003, no Apiahiki e no Okarasipi, a facilidade com que os materiais se inflamavam, acabando por incendiar a própria residência, no caso do Okarasipi.

O ato de viver ao seu modo expõe suas diferenças e, por contraste denuncia onde estão as questões que justificam o diálogo planetário, como o excessivo uso de seus recursos que por sua vez causam modificações a prejudicarem o conjunto da vida, em diversas manifestações. Logo, aquilo que é usado para a condenação das práticas yanomami são o exato pensamento que leva ao malefício ao planeta, os Yanomami deixam de movimentar recursos como outras organizações sociais o fazem, sendo responsáveis assim por uma modificação sensível de aspectos climáticos dentre outros. Eventos de seca, associados a uma predisposição de queima, demonstram uma predição de Fearnside, entre outros, de a Amazônia tenderá a se tornar 'vítima' das mudanças climáticas, causando aumento de perda de vegetação por efeitos climáticos. Dois discursos de origens diferentes, mas em sinergia política e até lógica: afinal, a levar também a sério os catastrofismos simbólicos da frágil estabilidade do mundo, bem como a ciência "hard science" dos modelos prediz, tem mais sintonia entre si do que outros setores da sociedade da mercadoria às quais se contrapõe. Em última instância, é a esse aspecto do Estado, sua razão instrumental ligada ao interesse econômico (note, estamos ressaltando a força política dominante no Estado) a essa lógica instrumental guiando a uma divisão e nessa divisão uma intervenção sobre a natureza como algo externo, e isso vem voltando-se contra as sociedades humanas.

A definição de povo da mercadoria de Davi, está sintonzada com os problemas do mundo atual, às quais somos chamados a pensar. $\mathrm{O}$ faz do ponto de vista (de estar no mundo) de um habitante da floresta, que precisou sair para poder defender seu direito de continuar existindo. As bagagens acumuladas aí resultam num conhecimento digno de nossa atenção. Aliás é a nós que se dirige. Viveiros de Castro assume a seriedade da metafísica da instabilidade do meio natural, ao qual se deve defender e o faz, tal como seu mestre LeviStrauss, com etnologia comparando posições similares de geografias diversas, transcendendo até a etnologia ameríndia. Mas vem encontrando interlocução na ciência, pelo menos naquela em que se enfrentam os reducionismos extremos para se ter uma visão mais sistêmica, assumindo nossa intervenção planetária como digna de reflexão crítica; esses esforços são concomitantes a buscas por mudanças de paradigmas em diversos campos do conhecimento, tendo como um de seus protagonistas as mudanças na ciência física desde o aprofundamento 
na microfísica e na astronomia, onde o modelo newtoniano parece não resolver os enigmas.

Temos então um desafio para nossa filosofia, para torna-la conversável com outros modelos, o de admitir validade naquilo que chamamos de sobrenatureza (VALENTIM, 2013, 2014). O exílio da sobrenatureza, a pretexto de separar a ciência do mito, impede potencialidades filosóficas e nos impele ao estranhamento do pensamento indígena, onde esse exílio não ocorre. Conforme Danowski e Viveiros de Castro (2016), é a sobrenatureza capaz de provocar a dupla torção a inverter a lógica entre natureza e cultura, colocando a natureza no eixo transformacional, agente, e a cultura como dada, na sua lógica multinaturalista. A exposição de outros modelos metafísicos aos quais nossa filosofia condenaria o uso de elementos sobrenaturais parece ser mais adequado nos modos de se tratar a terra, por lhe atribuir um sentido distinto da nossa divisão fundadora de natureza e cultura. Nossas metáforas alternam-se na busca da imagem mais próxima mais adequada de compreensão; felizmente já abandonamos a comparação com a máquina, para descrevermos nossa própria corporalidade. $\mathrm{O}$ envolvimento com a floresta confere às populações ameríndias lógicas diferentes, implicando em práticas igualmente diferentes. Inverto aquio título de um texto clássico de Descola (DESCOLA e PALSSON 1996: 82-102): 'prática ecológica e sociologia simbólica' parece-me mais adequado para entender sua ideia de construir natureza; e eu fugiria ao seu sentido categorizador, compreendendo melhor a bomba epistemológica necessária para o nosso constructo de natureza e cultura. Uma sociologia simbólica, numa negociação constante com todos os seres extrahumanos parece-me mais adequada. E expressa a cisão diacrítica com a filosofia do "Povo da Mercadoria", incontornável, antes de levarmos seu pensamento, carregado de elementos de sobrenatureza, a sério. A sociologia simbólica quase nos indistingue dos elementos da natureza, e isso é um trunfo, pois o grande equívoco de nossa presunção é o de imaginarmos alterando irreversivelmente o planeta onde vivemos sem sofrermos as consequências. E ainda chegarmos a tal totalitarismo e monopólio da razão de nem sequer respeitar a presença indígena onde já estavam/ estão.

\section{Do mundo hoje:}

Nesse subtítulo abarco algumas premissas utilizadas para analisar resumidamente o mundo hoje, especialmente frente à hegemonização do capitalismo enquanto sistema global, a totalização do Estatuto de Estado Nacional, e as condições dadas para povos indígenas, suas possibilidades de estratégias num mundo atual em que se inserem sem ser avisados, sem aula prévia sobre o dito sistema. Vou refletir sobre o momento atual do Capitalismo mundial e as 
perspectivas para os povos indígenas; como afirmamos, enquanto sociedades contra o Estado, a negação de admitir para si uma organização social centralizada, imprime condições diferenciadas em relação às formas convencionais de luta contra o Capital.

Os Estados Nacionais sempre se pautaram pela exploração dos recursos de seu território, arrogando-se o direito sobre o que nele há; com o desenvolvimento do capitalismo de grandes corporações os Estados favorecem sua inserção no território, beneficiando-as com facilidades que vão desde garantir a sobrevivência de sua mão de obra necessária, subsidiando transporte, saúde, educação, até conceder partes do território para exploração. Constróem estradas e portos e ajudam a criar mercados consumidores. O principal objeto de interesse do Estado sobre os povos indígenas é sua terra e as riquezas nela contidas. Dessa forma, as populações indígenas sempre serão um entrave ao desenvolvimento do Estado Nacional pois pertencem à terra que deveria ser explorada, aquela que considera seu território sem participar dos mesmos interesses, oferecendo resistência às alterações que o Estado e o poder econômico se põe a a implementar, com vistas à exploração dos recursos. Não à toa, durante quase toda primeira metade do Séc $\mathrm{XX}$ as terras indígenas eram demarcadas sem garantir a sobrevivência de cada sociedade indígena enquanto povo diferenciado, com suas necessidades reais. Eram terras diminutas, e a perspectiva a esses povos era o desaparecimento, via integração (AZANHA; VALADÃO, 1991). Apenas após a criação do Parque do Xingu (1961) que passou-se a se preocupar com a sobrevivência deles enquanto povos, reconhecendo extensão significativa de seu território originale fundamentada em garantir a sobrevivência e o Direito a viver segundo "seus usos costumes e tradições".

Como contrapesos, o período de democratização (década de 1980) teve o movimento índígena e indigenista como um dos protagonistas, um dos primeiros a se organizar ainda na década de 1970. Lembro-me bem da agenda positiva divulgada como se fosse manchete de jornal, apresentando, dentre outras pautas populares (reforma agrária e urbana, defesa do patrimônio natural e ambiente saudável, constituinte livre e soberana) a demarcação das terras indígenas. Durante os anos que precedem e sucedem a constituição, 1988, a luta pelas demarcações de terras indígenas movimentaram o país, embora pouco noticiadas na imprensa. Dessas, a luta pela Terra Yanomami foi uma das mais dramáticas (Ricardo 1990, 1995), pelas perdas populacionais, e pelas teses que se disputaram, de um lado, os direitos indígenas, de outro os entraves ao desenvolvimento econômico e ameaças à soberania Nacional. 


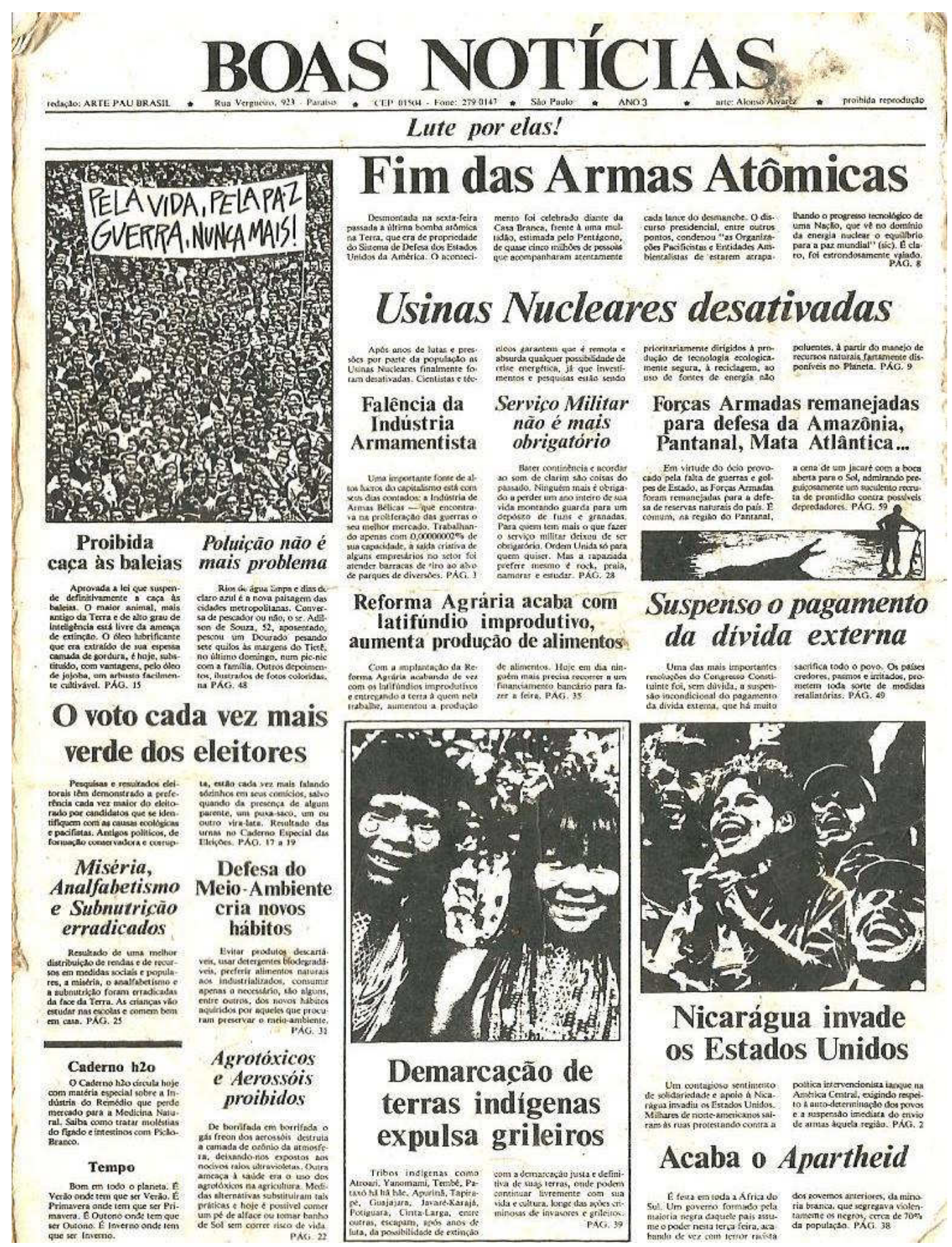

Figura 42 fac-símile de agenda "Boas Notícias", de 1985, época da luta pela redemocratização do país. Note o destaque dado à Demarcação das Terras indígenas.

No campo da etnologia Indígena, essa disputa teórica também teve seus reflexos: se de um lado, Chagnon (1968) em sua concepção exotizante de "povo feroz, selvagem" era utilizado pelos militares para justificar uma demarcação em ilhas, e de outro, Albert e Ramos demonstravam que a selvageria maior vinha do Estado e os Yanomami serem retratados muito mais em sua organização social, e suas necessidades ambientais de relação com a floresta (Albert, 1992). Até o argumento conservacionista foi utilizado, durante o Governo Sarney, para justificar a demarcação em ilhas (Albert 1991, 2000). O movimento ambientalista 
independente se mostrou forte aliado no processo de reconhecimento territorial, pois as terras indígenas, enquanto áreas protegidas, demonstraram grande eficácia na conservação dos ecossistemas e da vegetação (NEPSTAD; SCHWARTZMAN et al., 2006).

Foi no período posterior a esse, com apoio internacional (de povos, muito mais que de Estados, diga-se) em que foi possível executar o programa de formação que resultou nos jovens de quem falamos agora, já exposto no Capítulo I e III, com a prática democrática, as possibilidades de discussão de teses políticas, dentro ainda do âmbito do capitalismo, rediscutem o papel do Estado, dentro dos princípios expostos na CF 1988. A organização, dentro do governo federal de políticas públicas de saúde e educação e, mais recentemente a Política Nacional de Gestão Ambiental de Terras Indígenas (2012), quando praticamente formou-se a turma de professores Yanomami pelo PEI.

Esse período da redemocratização não foi isento de lutas e ameaças aos direitos indígenas, destacando-se invasões por atores do poder econômico e grandes projetos governamentais, dos quais estradas e hidrelétricas foram os principais. Emitiram um sinal anacrônico e contraditório de desenvolvimentismo, reativando setores imediatistas da exploração econômica para os quais a Amazônia só representa recuros naturais a serem explorados. Na Terra Yanomami, embora houvessem focos garimpeiros, a presença permanente dos postos de saúde inibia parcialmente uma retomada maciça da invasão, sobrevivendo alguns focos restritos a alguns lugares. Permanecia como uma grande ameaça de papel, no Projeto de Lei de Mineração em Terras Indígenas. E as fazendas no Ajarani, desintrusadas apenas em 2014. Isso pode ser entendido como uma continuidade nas conquistas sociais, que sempre sofreram grande pressão por parte dos setores conservadores da sociedade nacional. A situação atual pode ser vista como reação às conquistas da redemocratização.

\section{A situação atual de retirada de direitos:}

Se a redemocratização representou um avanço no reconhecimento dos direitos indígenas, dentre outras demandas da sociedade, estabelecendo um estatuto jurídico consistente sobre o que é uma terra indígena, um marco da reação pode ser considerado o Julgamento da Terra Indígena Raposa Serra do Sol, homologada em 2005. Foi nesse processo que a recorrente judicialização das disputas sobre terras indígenas se apresenta como uma vitória, mas já indicando caminhos para a reação conservadora e anti-indígena: no intuito de 
tentar delimitar o que pode ser considerado terra indígena, o Ministro Menezes Direito apresenta as famigeradas "19 condicionantes", dentre as quais, estão: de que só poderiam ser consideradas aquelas em que os indígenas estivessem nas terras na data da promulgação da constituição, e desde que não houvesse o esbulho. Daí produz-se as teses do marco temporal e do esbulho renitente, defendido pelos setores do agronegócio interessados na paralização das demarcações de terras indígenas. As teses se somam a outras tentativas de, no âmbito do legislativo, se retirar, na prática, o Direito à Terra: novas propostas de alteração da constituição, para que o ato administrativo da demarcação da terra passasse pelo congresso, a PEC 215, tornando-se um ato político, onde a defesa de um direito de uma parte da população reconhecidamente ameaçada pelo poder econômico passasse a ser visto como um grupo privilegiado; isso evidentemente escondia a real intenção de o poder econômico se apropriar das últimas terras ainda protegidas da mercantilização fundiária.

As terras indígenas em reivindicação nesse período se referiam a grupos residentes nas áreas de ocupação consolidada do país, no centro-sul e nordeste. Desses, especialmente os Guarani Kaiowá apresentavam situação bastante delicada, pela sua grande população (uma das maiores do país) e pelo esbulho ter ocorrido em tempos de Mate-Laranjeira, uma companhia que colonizou o sul do Mato Grosso do Sul, território tradicional Guarani Kaiowa. Os Guarani nunca esqueceram suas terras, mesmo depois de se transformarem em áreas colonizadas; isso acarretou um maior potencial de conflitos, criando uma aliança entre fortes setores econômicos, bastante interligados: proprietários de terras, proprietários de concessões de meios de comunicação, tais como rádios e TVs, bem como proprietários de jornais, desenvolveram campanhas e versões de notícias dos conflitos que acabaram por colocar boa parte da população em geral contra as reivindicações dos povos indígenas.

Com o aumento da participação dos Yanomami na vida política relacionada à defesa de seus direitos, aumentou concomitantemente o contato com o movimento indígena brasileiro, empenhado em divulgar toda essa pauta dos setores anti-indígenas, e oferecer resistência contra o que vem sendo o maior ataque contra os Direitos Indígenas, bem como a outros setores da sociedade, que vêm sofrendo enorme retirada de direitos.

A situação da Terra Yanomami, com mais de 80 focos de invasão garimpeira, algumas congregando mais de dois mil participantes. A imbricação disso com a atuação política de parlamentares anti indigenistas, dos quais o mais emblemático ali é o Senador Romero Jucá, 
mas não o único, pois são os representantes dessa corrente diacriticamente oposta ao que os povos indígenas no seu pensamento cosmopolítico têm a potência de oferecer, enquanto projeto de convivência planetária: uma oposição ao sistema destrutivo que põe em risco a nossa sobrevivência no planeta, mas a um prazo mais curto, tem significado a desestruturação de populações inteiras.

A luta indígena parece aliar o desejo intrínseco desses povos na proteção de seus direitos, com um esclarecimento maior do contexto político do papel contraditório do Estado Nacional e das potências inerentes aos seus modo de pensar e habitar, enquanto formadoras de um projeto político fundado na insubordinação, igualmente percebido por diversos pesquisadores que fizeram dessa questão política indígena objeto de reflexão. As lutas indígenas carregam boa parte de suas práticas cosmopolíticas, e por isso, tem o potencial de trazer uma radicalização da prática democrática, nascida dessa recusa inerente à postura, no sentido ampliado de contra a uniformização, levando a um processo de singularização, quase nunca institucionalizado, um processo criativo frente à tentativa de imposição da homogeneização das sociedades. 


\section{Conclusão: a elaboração yanomami}

Reflexividade é uma potência da pesquisa etnográfica, quando estudar um povo depende da sensibilidade de percebe-la como uma relação intersubjetiva. Não se trata de escrever 'sobre esse povo', porque ao estudarmos, buscamos compreender igualmente quem nós somos, enquanto interagimos. Estudamos a relação (STRATHERN, 2014). Conhecemos o outro e refletimos sobre nós mesmos. O outro também. Há uma incomunicabilidade a ser resultado de um problema de linguagem: o modo como os nossos conceitos se intercadeiam não é igual ao que encontramos nas filosofias ameríndias. Tentando resumidamente explicar, vêm sendo observado no modo como alguns povos pensam, e como isso retorce os conceitos nossos e deles de natureza e cultura; há também sempre dois pólos, o da transformação e o considerado como dado; nosso conceito de cultura está no lado transformador (somos sujeitos frente a uma natureza objeto) e a natureza é considerada o dado, enquanto nessas sociedades ameríndias, o cultural é o dado enquanto a natureza é o pólo transformador.

Sobre o modo de organizar dessa tese, sobre a opção de manter uma frente de estudos intercalados, embora pouco usual, teve o objetivo mesmo de centrar o foco na localidade de onde se fala, e dali apresentar os elementos aqui discutidos. A escala da paisagem, diz Ladeira Maria (2016), permite justamente uma atenuação das dicotomias derivadas de natureza e cultura, porque vividas pelo sujeito, numa abordagem "estar no mundo", sem dissolve-la totalmente. Bruce Albert (1985:763) advoga a necessidade de evidenciar todo o conjunto de elementos do sistema ritual Yanomami para obter uma compreensão holística dos Yanomami, assim revelando a organização social, para além da comunidade; é a compreensão de todo o sistema ritual que comanda essa dinâmica socioespacial dos Yanomami, revelando toda a rede de alianças à qual a comunidade reage. Tal sistema ritual envolve e regula as trocas matrimoniais, materiais e simbólicas, envolvendo também o consumo das cinzas de ossos dos mortos com seus aliados. Toda mobilidade, portanto, está de alguma forma inserida nessa lógica reguladora dos Yanomami, conforme apresentada por Bruce.

Aqui, eu retrato um fenômeno, a mobilidade, partindo da referência geográfica, e apresentando os elementos a dialogar mesclados, ordenados apenas pelo lugar de onde se fala. Esse privilégio da paisagem, tomada pelo movimento da trajetória, tem a escala do sujeito, tanto em sua interação com a paisagem, envolvendo suas transformações, quanto nas interações políticas com os outros agentes, os Yanomami e os não Yanomami. A singularidade 
de cada trajetória se põe como recusa a uma abordagem reducionista, em que a experiência possa ser decodificada em elementos separados.

Alguns autores têm apontado para essas diferenças em lidar com a alteridade, seja ela os nарёрё (KELLY 2005, 2011, 2016), sejam os outros seres, entidades xamânicas e mesmo os animais; a existência do duplo animal rixia é uma referência de como a constituição do ser Yanomami é pensada: enquanto um ser que engloba outro, em outra floresta, incomunicável, equacionando humanos e não humanos. Somos nós mesmos, formato animal, vivendo em outra floresta; o animal é derivado de nossas semelhanças, têm características que se reconhecem em nossa personalidade ou traços físicos. Toma-se como questão a indissolução homem-animal, tanto no tempo mítico da criação como no presente; essa indissolução nos põe a condição de experimentar (nas viagens xamânicas, sobretudo) essa perspectiva distinta, quando mergulhamos na alteridade, nos tornamos 'outro'. Tornar-se outro, por sua vez, é o método de conhecer a alteridade; se está correta, para os Yanomami, o método da equivocação controlada (Viveiros de Castro 2004), como as praticas xamânicas de xapirimu parecem concordar, muda-se de perspectiva sabendo-se voltar. Trata-se de uma maneira de transitar em dois pólos, o mais Yanomami, e o mais 'outro'. A considerar como um contraste em nosso modo de conhecer, onde nos diferenciamos dos animais, nos colocamos diacriticamente, numa afirmação de nossa identidade. Não há possibilidade de trânsito. Assim, não seria bem sucedida uma busca por auqlquer forma de discurso que se assemelhasse aos nossos modos de conservação da natureza, porque não é assim que é pensado por eles.

Os Yanomami desenvolvem estratégias para lidar com adversidades, tanto de relacionamento com os outros, como climático-ambientais, de recursos, e sobretudo em relação ao contato permanente com as Sociedades de Estado. Na sua mobilidade reside um bom repertório. Esse desenho de possuir pontos de fuga, de possuir outro pólo como segunda residência combina analogicamente com o trânsito xamânico, de ir, sabendo voltar, bem como com 'virar napë', ou como uemaitpuo (uma imitação a toa), ou como modo de conhecimento do outro.

Tanto melhor quanto os contextos de contato permitirem, os processos que esclareçam nosso modo de pensar, nosso modo de ação e os objetivos de cada grupo de interesse sobre a terra e o povo, melhor os Yanomami poderão desenvolver respostas adequadas em sua auto defesa. E essas respostas devem sair segundo um modo próprio de pensar ou atuar, tal como o 
são no xapirimou. São a partir dessas representações que se imaginam as atualizações, a encaixar o elemento novo, outro, ao universo conhecido.

Disso se depreende o papel do intelectual indigenista napë, em traduzir nossa própria sociedade para o outro. E isso se faz através da aquisição de competências de operar com as ferramentas físicas e conceituais do outro. É ensinando matemática que se vence o desafio de não ser enganado nas contas, e dosar remédios. Tais práticas, enquanto competências estão no nosso campo hábil de faze-lo, tal como Manuela Carneiro da Cunha (2012) preconiza, de 'manter o seu lado', aquele que vc faz melhor, durante uma relação intercultural. Mesmo não tendo encontrado uma explicação em Yanomami sobre os efeitos na floresta de sua mobilidade, é evidente sua defesa (urihi yama a noamai) enquanto defesa de um modo de viver; são as práticas de manejo onde centramos o foco durante esse trabalho, percebendo lógica no que não foi explicitado com discursos.

O posto de saúde desempenha o papel de uma vacina etnográfica, muito por facilitar as defesas enquanto ainda se é dominante, maioria, ainda que se apreenda as competências com as ferramentas, outro aprendizado advém da convivência, numa percepção dos pequenos gestos, as portas trancadas, os medos, os humores. A experiência etnográfica do Autor evidencia a enorme busca e curiosidade em compreender melhor esse outro que ali se instala, que presta serviços de saúde. Tanto mais houverem ações e solicitudes por parte dos não indígenas em atender tais demandas, mais o posto manterá seu interesse por parte dos Yanomami.

Os Yanomami têm interesse no contato, no que ele proporciona, tornando-se uma relação de medo e necessidade; amizade e desconfiança; desenvolvem então estratégias de estar perto e estar longe, com a prerrogativa de decisão. No Toototopi identifiquei nas mobilidades o uso de segundas residências, em que se cria um pouso, uma roça alternativa numa localidade longínqua. É fundamental afirmar a relação com a floresta em seu modo de vida: quando buscam as ferramentas de metal, ou outros utensílios, o único foco está em viver melhor na floresta. Não se trata de uma troca de um por outro, nem de uma divisão do espaço, mas de uma subordinação dos utensílios a uma necessidade real para lidar com a floresta.

Permanece válida a luta de Davi em, tendo entendido o perigo nesse fascínio com as mercadorias, com os bens materiais aos quais os jovens, sobretudo, se vêem fixados e tornam- 
se vulneráveis aos interesses dos napëpë, da sociedade não indígena. Nisso a memória histórica dos garimpeiros, oferecendo utensílios em troca de sua permanência na exploração aurífera é um aprendizado a não ser esquecido. E o posto, embora mal menor, exerce o mesmo papel de pólo de atração. Compreende-lo enquanto ameaça é inevitável. Advogo aqui as percepções dos Yanomami e a alternativa amparada em algo já pré-existente em suas práticas espaciais, a mobilidade.

Foi perceptível que as comunidades escolhem as adjacências do antigo pouso de morada (hutu waro pata, hikari pata, hikari suë pata). Isso deve ter fundo no interesse pelo próprio espaço criado, derivado da clareira de roça: de fato, ali se constitui num espaço diferenciado, onde há uma maior produtividade primária, com diversidade de pequenos recursos. E por ser espaço diferenciado, tem poder de atrair animais de caça. Além do Capítulo 2, tratamos desse assunto nos capítulos 4 (p.104), 5 (120-23) e 7 (165-66), de forma especulativa, ao demonstrar a intencionalidade da volta dos Moxihatetemapë às proximidades de uma velha roça.

Esse segundo pouso permite um movimento pendular, com ampla possibilidade de ação. Tal pendularidade poderia se expressar pelos recursos que acessam nas florestas, mas também pelo seu caráter humano de distanciar-se de certa inconveniência. Tanto no Toototopi, no Marauiá e no Homoxi há modalidades desse movimento. No Homoxi, interessa o movimento expulsivo do garimpo, o movimento de apropriação da presença não indígena no posto de saúde, bem como seu uso no caso dos conflitos intercomunitários; no Toototopi, a missão e o posto, e no Marauiá a referência espacial que representa o acesso é o rio, com os grupos organizando-se a ter pouso na beira de um curso navegável e outro pouso distante. Esse desenho observado tem congruências, como vimos, com o modo expresso de 'virar outro' sem deixar de ser 'Yanomami'; essa alteridade se expressa espacialmente, nas estratégias de lidar com o outro, tendo um movimento pendular de aproximação e afastamento (do outro e da sua própria familiaridade yahitheri).

Essas estratégias, no entanto, não são lineares, e não representam um caminho único, nem de aproximação e nem de afastamento, embora possamos considerar a existência de alguns padrões, eles não são nem únicos nem exclusivos, se analisados todos os casos, todas as condições encontradas. No Toototopi, há diversos exemplos em que a mobilidade fôra usada como rota de afastamento, todavia, temo o caso do Xiroxiropi, depois da longa 
trajetória narrada por Barbosa, e seu desejo de fixação levado a cabo ali, onde já conquistou pista (pela longa distância do posto). O mesmo pode se relatar do Piau, um dos casos estudados para argumentar a inteligência e o debate levando à mobilidade; hoje, este se encontra com pista de pouso, e uma nova condição, mas não significa um 'fim da história'; as pistas e postos trouxeram um real novo elemento com o qual há uma dialogia espacial, requerendo inventividade frente ao novo. E a resposta pode ser mover-se ou permanecer.

Essa tese, apresentada em seus apontamentos dos Yanomami, tem um poder de nos provocar a vontade de voltar os olhos para nós, viventes compartilhando uma sociedade de Estado: dos vários casos estudados, diz Kelly (2011: 221),

"For several Amazonian peoples with distinct forms of social organization and historical relations with their respective states, such as the Kayapó (Gordon, 2006), the Piro (Gow, 2001), the Wari' (Vilaça, 2006), and the Yanomami, whites remain at once as canonical others and sources of difference to be internalized to propel community life into the future."

Nós é que somos os outros; para tantos povos, é nossa condição de estar do outro lado da dupla torção, e precisamos ser estudados. Quando Kelly refere-se a 'brancos', as sociedades de Estado, aqueles que se propuseram modernos. Nós, enfim; mas esse 'nós' é mais ou menos inclusivo, ao ponto de setores da sociedade de classes, estarem muito mais como excluídos dessa modernidade. Assim, o projeto de organização social representado pelo Estado, merece ser repensado. Nos cabe rever dicotomias natureza cultura, e todas suas dicotomias consequentes.

Nesse trabalho eu retrato territorialidades em choque. As diversas formas de contato e interesses envolvidos, os Yanomami mantém entre si o seu modo de organização social, ao mesmo tempo, como diz Kelly, 'vira napë'. Espacialmente, observo o mesmo desenho, na atualização da pendularidade para a presença minoritária napë. Mesmo vivendo sobre os escombros deixados por uma sociedade majoritária, os Homoxi guiam-se em manter sua territorialidade numa condição ambientalmente desfavorável pela permanência do posto, quando lá ainda tentava continuar o trabalho da Urihi (até 2007). Com a reinvasão (2014, pelo menos), uma atitude guiada pelo preço do grama de ouro, por relações internacionais de valoração das coisas . Em seu mundo autista, as sociedades de Estado se seus mercados, 'o povo da mercadoria' não consegue introjetar na sua valoração haver gente, com seu mundo significativo, florestas, seus duplos igualmente valoráveis. Menosprezando o sobrenatural contido no pensamento indígena, o moderno é capaz de subtrair a floresta, pois não vê nela mais do que coisas valoráveis. Aí consiste, em sua versão espacial, a territorialidade diacrítica 
das sociedades de Estado e o que reserva à sua periferia extrema: a desorganização social de uma região comandada por um sistema internacional de valoração. E a posição diacrítica de, como os cogumelos, permanecer indomável.

A indomabilidade foi descrita por Viveiros de Castro como a alteridade radical de nós. Porque, apesar de os modernos sermos a alteridade radical de todos os outros (inclusive de muitos de dentro desse Estado, moderna), os índios foram como Padre Vieira os descrevera em o mármore e a Murta, a inconstância da alma selvagem. E nenhum yanomami manda em outro; esse ethos, de contestação da autoridade o vi inclusive em cenas com Davi Kopenawa, respeitado, mas deverá sempre ouvir o outro.

Uma recusa em ser servil leva a uma busca de respostas no seio de sua criatividade, não como apenas um gesto mecânico e previsível. Parte dos recursos utilizados implica na subeversão da própria língua, reatribuindo significados, metaforizando. Parte dessa atitude resulta num protagonismo yanomami, cujas soluções territoriais, nem sempre explícitas e legíveis como são as demarcações de fronteiras, como fazem as sociedades de Estado, são iniciativas próprias e elaboradas; esse protagonismo vem sendo destacado nas falas de Davi. Isso subverte o discurso colonial de retirar a prerrogativa, a deliberação pelo outro.

Terminemos devolvendo ao ambiente a discussão onde começou: o modo autogestionário nesse caso pode significar a melhor organização na 'gestão' ambiental? Ou há uma indissociabilidade entre a estrutura espacial, a produção do espaço relacionada ao sistema político que a governa: o fissionalista parece permitir maior chance de regeneração da floresta, de modo a tornar-se indissociável o que se aborda por vias materiais de ciências naturais, físicas, e as posições (cosmo-)políticas adotadas nos contextos de existência: defender e ocupar a floresta torna-se uma ação política enquanto a ação política de recusa de Estado, de centralização e verticalização da sociedade torna-se uma ação ambiental, de caráter ecológico. A produção do Espaço, nesse contexto, mostra-se, da costumeira invisibilidade que se coloca sobre a contribuição indígena na paisagem florestal amazônica, como uma ação deliberada, uma criatividade relacionada a uma organizaçã social fundada na recusa a uma subordinação, bem como uma constante preocupação com o equilíbrio e estabilidade do mundo. Uma postura de recusa não se faz por desinteresse, há uma permeabilidade na percepção yanomami do outro, onde transitar não é negado. O trânsito implica nessa volta, numa pendularidade relacional, que se reflete espacialmente. 


\section{Referências}

AGAMBEN, G. profanations Paris: Payot et Rivages 2005

ALBERT, B. Temps du sang, temps des cendres: representation de la maladie, système rituel e espace politique chez les Yanomami des Sud-est (Amazonnie Brasilienne). (doctoral thesis). Nanterre Paris X Nanterre Paris, France, 1985. 800 p. p.

. Yanomami "Violence": Inclusive Fitness or Ethnographer's Representation? Current Anthropology, v.30, n.5, Dec. 1989, p.p.637-640. 1989.

On Yanomami Warfare: Rejoinder. Current Anthropology, v.31, n.5, Dec. 1990, p.558-563. 1990.

Terra Yanomami e Florestas Nacionais no Projeto Calha Norte: Uma expropriação "Ecológica" In: C. A. RICARDO (Ed.). Povos Indigenas do Brasil 1986-90. São Paulo SP: CEDI v.16, 1991. Aconteceu Especial, p.166-169.

. Urihi: Terra, Economia e Saúde Yanomami. Série Antropologia 119: 1-20 p. 1992.

Anthropologie appliquée ou "anthropologie impliquée"? Ethnographie, minorités et développement. In: B. JEAN-FRANÇOIS (Ed.). Les applications de l'anthropologie : un essai de réflexion collective depuis la France. . Paris: Karthala, v.Hommes et Sociétés, 1995, p.87118.

Terra Ecologia e saúde indígena: o caso Yanomami. In: R. I. BARBOSA, E. J. GONDIM et al (Ed.). Homem, Ambiente e Ecologia no estado de Roraima. Manaus AM Brasil: Inpa, 1997a, p.65-83.

Yama ki hwerimamouwi the ã oni - Palavras escritas para nos curar. Brasília: MEC/SEF/CCPY. 1997b. 91 p.

O massacre de Haximu. Folha de São Paulo. São Paulo. 03/10/1993 2001[1993].

O ouro canibal e a queda do céu: uma crítica xamânica da economia política da natureza. In: B. ALBERT e A. R. RAMOS (Ed.). Pacificando o Branco. São Paulo: Imprensa Oficial do Estado SP Ed. Unesp, 2002, p.239-275.

Anthropologie et recherche biomédicale : le cas yanomami (Venezuela et Brésil) In: D. BONNET (Ed.). L'éthique médicale dans les pays en développement Paris Autrepart / IRD - Éditions de l'Aube, v.28, 2003, p.125-146.

ALBERT, B. e G. G. GOMEZ. Saúde Yanomami: um manual etnolingüístico. Belem-PA Brasil: Museu Paraense Emilio Goeldi. 1997. 304 p. (Col. Eduardo Galvão)

ALBERT, B. e F. M. LE TOURNEAU. Homoxi: ruée vers l'or chez les indiens Yanomami du haut Rio Mucajaí. Autrepart, v.34, n.2, p.184. 2005.

Etnogeography and resource use among the Yanomami: Towards a model of reticular space. Current Antropology, v.48, n.4, p.584- 592. 2007. 
ALBERT, B. e M. W. OLIVEIRA. Novos "isolados" ou antigos resistentes? In: C. A. RICARDO e F. RICARDO (Ed.). Povos Indígenas no Brasil 2006-2010. São Paulo: Instituto Socioambiental, 2011. Aconteceu Especial Povos Indígenas no Brasil, p.279-283.

APPADURAI, A. O medo ao pequeno Numero ensaio sobre a Geografia da Raiva. São Paulo: Iluminuras/Itau Cultural. 2009. 96 p.

AQUINO, R., R. E. BODMER et al. Mamiferos de la cuenca del rio Samiria: ecologia poblacional y sustentabilidad de la caza. Lima, Perú: Instituto de Ciencias Biológicas Antonio Raimondi Universidad Nacional

Mayor de San Marcos. 2001

AZANHA, G. e C. R. OTAVIO. Isolados, algumas questões para reflexão. São Paulo: centro de trabalho indigenista (CTI). 20172010.

AZANHA, G. e V. VALADÃO. Senhores dessas terras. São Paulo: Atual. 1991. 82 p. (História em documentos)

BALÉE, W. Footprints of the Forest: Ka'apor Ethnobotany-the Historical Ecology of Plant Utilization by an Amazonian People New York: Columbia University Press. 1994

BALÉE, W. e C. L. ERICKSON. Time and Complexity in Historical Ecology: Studies in the Neotropical Lowlands. New York: Columbia University Press. 2006

BALÉE, W. L. Cultural forests of the Amazon : a historical ecology of people and their landscapes. Tuskaloosa: The University of Alabama Press. 2013. 289 p.

BARBOSA, G. C. Da troca de bens. In: D. GALLOIS (Ed.). Redes de Relações nas Guianas. São Paulo: Editora Humanitas/FAPESP., 2002.

BODMER, R. E. e J. G. ROBINSON. Evaluating the Sustainability of Hunting in the Neotropics In: K. M. SILVIUS, R. E. BODMER et al (Ed.). People in Nature Wildlife Conservation In South And Central America. New York: Columbia University Press 2004.

BRASIL. Projeto Radam Brasil. Rio de Janeiro RJ Brasil: IBGE, v.8. 1975 (Levantamento de recursos naturais)

. Constituição da República Federativa do Brasil. Brasilia DF: Senado Federal: Centro Gráfico: 292 p. 1988.

BUSH, M. B. e M. R. SILMAN. Amazonian exploitation revisited: ecological asymetry and policy pendulum. Frontiers in Ecology and the Environment, v.5, n.9, nov 2007, p.457-465. 2007.

CAMPOS, M. A. Na roça com os Pataxó: etnografia multiespécie da mandioca na aldeia Barra Velha do Monte Pascoal, Sul da Bahia. interunidades Ecologia aplicada, USP, Piracicaba, 2016. $251 \mathrm{p}$.

CARDOSO, T. M. Paisagens em transe: uma etnografia sobre poética e cosmopolítica dos lugares habitados pelos Pataxó no Monte Pascoal. PPGAS, UFSC, Florianópolis 2016. 524 p. 
CARNEIRO DA CUNHA, M. M. Questões suscitadas pelo conhecimento tradicional. Revista de Antropologia, v.13, n.1, 06/11/2012, p.439-464. 2012.

CASTRO, L. M. Kami yanomae yamakini yama thë ã oni pou: Nós yanomame pegamos a escrita. praticas e letramentos entre os yanomae. (MSc). antropologia/interinstitucional, UFPE, Recife e Boa Vista, 2013. 156 p.

CASTRO, L. M. e M. L. PEREIRA. Escrita Yanomami: reflexo das relações interculturais. Examãpaku, Revista UFRR, v.4, n.1. 2013.

CHAGNON, N. A. Life Histories, Blood Revenge, and Warfare in a Tribal Population. Science, v.239, n.4843, Feb. 26, 1988, p.985-992. 1988.

CHAGNON, N. A. e R. B. HAMES. Protein Deficiency and Tribal Warfare in Amazonia: New Data. Science, New Series, v.203, n.4383, Mar. 2, 1979, p.910-913. 1979.

CLASTRES, P. A sociedade contra o Estado. São Paulo SP: Cosac \& Naify. 2003. 280 p.

CLEMENT, C. R., W. M. DENEVAN et al. The domestication of Amazonia before European conquest. . Proc. R. S. B :. v.282, n.1812, p. 20150813. 2015.

CLEMENT, C. R., L. RIVAL et al. Domestication of Peach Palm (Bactris gasipaes): the Roles of Human Mobility and Migration. In: M. ALEXIADES (Ed.). Mobility and Migration in Indigenous Amazonia: contemporary ethnological perspectives. New York: Berghahn, v.11, 2009. Studies inenviromental Anthropology and Ethnobiology, p.117-140.

COLCHESTER, M. The economy, ecology and ethonobiology of the Sanema Indians of southern Venezuela Vol I. (doctoral thesis). University of Oxford, Oxford, 1982. $331 \mathrm{p}$.

CONNELL, J. H. Diversity in Tropical Rain Forests and Coral Reefs. Science, v.199, n.4335, Mar. 24, 1978, p.1302-1310. 1978.

DALMONEGO, C. "Paeterepë" quem são esses napëpë ? elementos para o estudo da construção yanomami da alteridade missionaria. Antropologia, PUC, São Paulo, 2015. 294 p.

DANOWSKI, D. e E. V. D. CASTRO. Há mundo por vir? Ensaio sobre os medos e os fins. Florianópolis: Cultura e Barbárie /Socioambiental. 2014. 176 p.

DELEUZE, G. e F. GUATTARI. Mil Platôs Capitalismo e Esquizofrenia I. Rio de Janeiro: Ed.34, v.I. 1995. 94 p. (Capitalismo e Esquizofrenia) O Anti Édipo. São Paulo: 34, v.I. 2010 (1972). 94 p. (Capitalismo e Esquizofrenia )

DESCOLA, P. Estrutura e Sentimento: a relação com o Animal na Amazôna. MANA, RJ v.4, n.1, p.23-45. 1998.

DESCOLA, P. e G. PALSSON. Nature\&Society Anthropological perspectives. Londres: Routeledge. 1996. 295 p. 
DINIZ, D. Avaliação ética em pesquisa social: o caso do sangue Yanomami. Bioética/Brasília, v.15, n.2. 2007.

DO PATEO, R. D. Niyayou: Antagonismo e aliança entre os Yanomami da Serra da Surucucus, RR. (doctoral thesis). Departamento de Antropologia Social FFLCH, USP, São Paulo, 2005. 255 p.

. Yanomami/garimpo: O retorno do caos. Povos Indígenas do Brasil 2001-2005. C. A. RICARDO. São Paulo: Instituto Socioambiental 2006.

DUARTE, R. e S. P. PELLEGRINO. Agressão, aliança e reflexividade: a guerra yanomami por meio de uma experiência de comunicação. . Sexta Feira: Antropologia, Artes e Humanidades, São Paulo, v.7, p.57-66. 2003.

FARAGE, N. As Muralhas dos Sertões: Os Povos Indígenas no Rio Branco e a Colonização. Rio de Janeiro RJ: ANPOCS, Paz e Terra v.1. 1991. 97 p.

FERGUSON, B. Ecological Consequences of Amazonian Warfare Ethnology v.28, n.3, Julho 1989, p.249-264. 1989.

- Yanomami Warfare, a political history. Santa Fe, New Mexico: School of American Research Press. 1995. 450 p.

FERREIRA, H. P. Esboço gramatical do Yaroamë, língua falada na Serra do Pacu RR. Projeto de Documentação das Línguas Ninam e Yaroam: Museu do Índio/ UNESCO. H. P. FERREIRA, YAROAMË, M., GOMEZ, G.G., MENDES, G.L., XIRIANA, A., XIRIXANA, I. 2011.

FERREIRA, H. P., G. G. GOMEZ et al. Projeto de Documentação das Línguas Ninam e Yaroami: Museu do Índio/ Unesco: 30 p. 2010.

FRANCISCO, D. A. e C. E. OLIVEIRA. Projeto de saúde Yanomami no Demini, Tootobi e Balawaú. In: C. A. RICARDO (Ed.). Povos Indígenas do Brasil 1991-1995. São Paulo: Instituto Socioambiental, 1996. Aconteceu Especial Povos Indígenas do Brasil, p.213-215.

GOOD, K. R. Yanomami hunting patterns: Trekking and garden relocation as an adaptation to game availability in Amazonia, Venezuela. (doctoral thesis). University of Florida, Florida, 1989. $180 \mathrm{p}$.

GOW, P. "Me deixa em paz!" Um relato etnográfico preliminar sobre o isolamento voluntário dos Mashco. Revista de Antropologia, v.54, n.1, janeiro-junho 2011, p. 11-46 2011.

GUIMARÃES, S. M. F. Cosmologia Sanumá: O Xamã e a Constituição do Ser. Antropologia UnB, Brasilia, 2005a.

. Reflexões Sanumá e o surgimento dos brancos. Revista de Estudos e Pesquisas, FUNAI, Brasília, v.2, n.2, dez 2005, p.53-77. 2005 b.

HARRIS, M. Animal Capture and Yanomamo Warfare: Retrospect and New Evidence. Journal of Anthropological Research, v. Vol. 40, No. 1, p.pp. 183-201. 1984. 
HARVEY, D. Modo capitalista de produção do espaço. São Paulo: Anna Blume. 2005. 251 p. (geografia e adjacências)

INGOLD, T. Perception of the environment. New York: Routeledge. 2000

Culture on the ground the world perceived through the feet. Journal of Material Culture, v.9, n.3, p.315-340. 2004.

Being alive Essays on movement knowledge and description. London/NYork: Routeledge/Taylor\&Francis Library. 2011.269 p.

JABUR, C. C. Os tiko töpö: uma reflexão sobre as categorias de alteridade dos Sanuma (subgrupo Yanomami). (Dissertação). DAn Departamento de Antropologia, PPGAS, UNB, Brasília, 2014. 132 p.

JEROZOLIMSKI, A. e C. A. PERES. Bringing home the biggest bacon: a cross-site analysis of the structure of hunter-kill profiles in Neotropical forests. Biological Conservation v.111, p. 415-425. 2003.

KELLY, J. A. Notas para uma teoria do "Virar branco". Mana v.11, p.201-234. 2005.

State Healthcare and Yanomami Transformations: A Symmetrical Ethnography. Arizona The University of Arizona Press/The Arizona Board of Regents. 2011

Aprendendo sobre os diálogos cerimoniais Yanomami Species(NAE), v.1, n.1, novembro 2015, p.45-65. 2015.

KELLY, J. A. K. L. “Os Encontros de Saberes”:equívocos entre índios e Estado em torno das políticas de saúde indígena na Venezuela. Ilha, v.11, n.2, outubro 2010, p.265-302. 2009.

KELLY LUCIANI, J. A. Sobre a antimestiçagem. Desterro, [Florianópolis]: Cultura e Barbárie. 2016. 112 p. (Species - Núcleo de Antropologia Especulativa)

KERN, D. C. e N. KÄMPF. O efeito de antigos assentamentos indígenas na formação de solos com terra preta arqueológica na região de Oriximiná-PA Revista Brasileira de Ciência do Solo, v.13, p.219-225. 1989.

KOPENAWA, D. e B. ALBERT. La Chute du Ciel. Paroles d'un Chaman Yanomami. Paris:: Terre Humaine, Plon, . 2010. 820 p.

A queda do Céu, Palavras de um xamã Yanomami. São Paulo SP: Companhia das Letras. 2015. $730 \mathrm{p}$.

LATOUR, B. jamais fomos modernos ensaios de antropologia simétrica. Rio de Janeiro RJ: 34/ Nova Fronteira. 1994. 152 p.

LAUDATO, L. Yanomamö pey keyo. Brasília Brasil: Universa Editora(UCB). 1998

LE TOURNEAU, F. M. Les Yanomami du Brésil : Géographie d'un territoire amérindien. Paris Belin. 2010. 480 p. (Mappemonde) 
LE TOURNEAU, F. M. e B. ALBERT. Homoxi (1989-2004): o impacto ambiental das atividades garimpeiras na Terra Indígena Yanomami (Roraima). In: R. I. BARBOSA e V. F. MELO (Ed.). Roraima, Homem, Meio Ambiente e Ecologia. Boa Vista: FEMACT/INPA v.II, 2010.

LEFEBVRE, H. the Production of Space. Oxford UK; Cambridge Mass. USA: Basil Blackwell. 1991

LEITE, T. V. S. Imagens da Humanidade Metamorfose e moralidade na mitologia Yanomami. Mana, v.19, n.1, p.69-97. 2013.

LÉVI-STRAUSS, C. O pensamento Selvagem. Campinas SP: Papirus. 1989. 165 p.

LIMA, T. S. Um peixe olhou para mim: o povo Yudjá e a perspectiva. São Paulo/Rio de Janeiro: Unesp/ISA/NuTI. 2005. 404 p.

LIZOT, J. Économie primitive et subsistence - essai sur le travail et la alimentacion chez les Yanomami. Libre, v.78, p.69-111. 1978.

. La Agricultura Yanomami. Antropologica p.94. 1980.

Los Yanomami. In: G. FREIRE e A. TILLETT (Ed.). Salud Indigena en Venezuela.

Caracas: Ministerio de Salud, v.Vol.1, 2007, p.pp. 269-321.

LIZOT, J. e S. DART. On Warfare: An Answer to N. A. Chagnon. American Ethnologist, v.21, n.4, Nov. 1994, p.845-862. 1994.

MACHADO, A. M. A. "Lutamu": relações interétnicas e protagonismofeminino no Papiu no contexto de um conflito intercomunitário Yanomami. Antropologia, UFSC, Florianópolis, 2015. $232 \mathrm{p}$.

MACMILLAN, G. At the end of the rainbow? Goldland and people in the Brasilian Amazon. Londres: Earthscan. 1995. 199 p.

MARIA, Y. L. Paisagem: Cultura-Natureza em perspectiva. Departamento de Geografia, Universidade de São Paulo, São Paulo, 2016. 262 p.

MARIZ-MAIA, L. Hwaximu: Foi genocídio! Comissão Pró Yanomami -CCPY. Brasília. 2001

MARTIN, J. G. The path of health and the elusiveness of fertility: Partial translations between Yanomami People and doctors in the Venezuelan Amazon. (Dotcoral). Depth. Social Anthropology, University os Cambridge, Cambridge, 2016. 337 p.

MAZUREK, R. R. D. S., P. TEMEHE et al. Subsistence Hunting among the Waimiri Atroari Indians in Central Amazonia, Brazil. Biodiversity and Conservation, v.9, n.5, p.579-596. 2000 .

MEGGERS, B. Amazônia: a Ilusão de um Paraíso. Rio de Janeiro: Civilização Brasileira. 1977. $210 \mathrm{p}$.

MENEZES, G. H. Yanomami na encruzilhada da conquista contato e transformação na 
fronteira amazônica. Antropologia, UnB, Brasilia, 2010. 249 p.

MILLIKEN, W. e B. ALBERT. Yanomami: a forest people. London UK: Royal Botanic Gardens, Kew. 1999. 161 p.

MILLIKEN, W., B. ALBERT et al. Degraded areas in the Yanomami Territory, Roraima, Brasil: Ethnoenviromental evaluation of the Homoxi region. Boa Vista Roraima 2002.

NEPSTAD, D., S. SCHWARTZMAN et al. Inhibition of Amazon Deforestation and Fire by Parks and Indigenous Lands. Conservation Biology, v.20, n.1, p.65-73. 2006.

NILSSON, M. S. T. Organização Indígena Yanomami: das ameaças ao seu território à representação política numa sociedade sem Estado. Agrária, v.9, p.25-43. 2011.

NILSSON, M. S. T. e P. M. FEARNSIDE. Yanomami Mobility and its Effects on Forest Landscape. Human Ecology, v.39, n.3, p.235-256. 2011.

Demografia e mobilidade Yanomami: Avaliando mudanças socioambientais. Novos Cadernos NAEA, v. 20, n.2, p.27-50. 2017.

PEREIRA, L. F. Massacre dos outros, massacre de nós mesmos: reflexões sobre uma teoria yanomami de construção de alteridades Reunião de Antropologia do Mercosul Porto AlegreRS 2007.

Nossos brancos nossos instrumentos: análise da construção de teorias Yanomami sobre alteridade a partir das situações de contato. antropologia, USP, São Paulo, 2008. 229 p.

PERES, C. A. Effects of Subsistence Hunting on Vertebrate Community Structure in Amazonian Forests. Conservation Biology v. 14, n.1, Feb., 2000, p.pp. 240-253. 2000.

PETERSEN, J., E. G. NEVES et al. Gift from the past: Terra Preta and Prehistoric occupation in Amazonia. In: C. MCEWAN, C. BARRETO et al (Ed.). Unknown Amazon: Culture in nature in ancient Brazil London: The British Museum Press ISBN 0 7141 2558X, 2001, p.86104.

PITHAN, O. A., U. E. C. CONFALONIERE et al. Situação dos Índios Yanomami: Diagnostico a Partir da Casa do Índio de Boa Vista, Roraima, 1987-1989. Cadernos de Saúde Publica, v.7. 1991.

PITHAN, O. D. A. O Modelo Hekura para Interromper a Transmissão da Malária: Uma Experiência de Ações Integradas de Controle com os Indígenas Yanomami na Virada do Século XX. (Dissertação de Mestrado). Escola Nacional de Saúde Pública Sérgio Arouca, Fundação Oswaldo Cruz, Boa Vista RR Brasil, 2005. 213 p.

PÓVOA, H. O cérebro desconhecido como nosso intestino afeta nossas emoções, regula nossa imunidade e funciona como um órgão inteligente Rio de Janeiro: Objetiva. 2002. 222 p.

PUERTAS, P. E. e R. E. BODMER. Hunting Effort as a Tool for Community-Based Wildlife Management in Amazonia. In: R. E. B. JOSÉ M. V. FRAGOSO, AND KIRSTEN M. SILVIUS (Ed.). People in Nature Wildlife conservation in South and Central America. NEW YORK: COLUMBIA UNIVERSITY PRESS 2004, p.pp. 123-137. 
RAMALHO, M. Os Yanomami e a morte. (PhD thesis). departamento de Antropologia, Universidade de São Paulo, São paulo, 2008. 168 p.

RAMOS, A. R. os nomes pessoais e classificação social em uma sociedade Sanumá (Yanoama). Serie Antropologia, v.2, p.15. 1973.

. Rumour: the ideology of an intertribal situation. Antropologica, v.51, p.3-25. 1979.

categorias étnicas do pensamento sanumá: contrastes intra e interétnicos. Antropologia, v.45, p.1-19. 1984.

Memórias Sanumá: espaço e tempo em uma sociedade Yanomami. São Paulo/ Brasília: Marco Zero/ UnB. 1990. 344 p.

1991

. Auaris revisitado. Comissão pela Criação do Parque Yanomami CCPY. São Paulo.

. O papel político das epidemias: o caso Yanomami. Série Antropologia. Brasília: UNB. 153: 1-21 p. 1993.

REIG, A. "When the forest world is not wide enough we open up many clearings" the making of Landscape, place and People among the Shitari Yanomami of the Upper Ocamo Basin, Venezuela. Institute of Social and Cultural Anthropology, University of Oxford, Oxford, 2013. 275 p.

RICARDO, C. A. Povos indígenas no Brasil/83 São Paulo: CEDI- Centro Ecumênico de Documentação e Informação, v.14. 1984. 248 p.

Cronologia de um genocídio documentado In: C. A. RICARDO (Ed.). Povos Indígenas do Brasil, 1986-90. São Paulo SP Brasil.: Centro Ecumênico de Documentação e Informação - CEDI v.16, 1991. Aconteceu Especial, p.166-169.

- Povos Indígenas do Brasil,1995-2000 S Paulo SP Brasil: ISA. 2001. 448 p. (Aconteceu Especial )

. Povos Indígenas do Brasil 2001-2005 ISA. S Paulo SP Brasil. 2006

RIVIÈRE, P. Aspects of Carib political economy. . Antropológica, v. 59, n.62, p.349-358. 1983-84.

Individual and society in Guiana: a comparative study of Amerindian social organization. . Cambridge: University Press. 1984

RIVIÈRE, P., D. F. GRUPIONI et al. A propósito de Redes de relações nas Guianas. Mana[online], v.13, n.1, p.251-273. 2007.

RODRIGUES, D. Proteção e Assistência à Saúde dos Povos Indígenas Isolados e de Recente Contato no Brasil. M. D. S.-P. P. I. I. V. C. I.-M. ESTRATÉGICO: Secretaria Permanente Organização Tratado de Cooperação Amazônica: 130 p. 2014. 
ROOSEVELT, A. Parmana: pre historic maize and manioc subsistence along the Amazon and the Orinoco. New York USA: Academic Press. 1980

Determinismo ecológico na interpretação do desenvolvimento social indígena da Amazônia. In: W. A. NEVES (Ed.). Origens, Adaptações e diversidade biológica do homem nativo da Amazônia. Belém: Museu Paraense Emilio Goeldi/ CNPq, 1991. Coleção Emilie Snethlage, p.p.103-141.

ROUSSEAU, J. J. Do Contrato Social: Ridendo Castigat Mores. 1762[2001]. 212 p.

SAFATLE, V. Grande hotel abismo: por uma reconstrução da teoria do reconhecimento. São Paulo: Martins Fontes 2012. 308 p.

SAHLINS, M. D. The Original Affluent Society. In: (Ed.). Stone-age economics. London UK: Routledge, 1972, p.1-40.

SANTOS, M. Por uma outra globalização do pensamento único à consicência universal. Rio de Janeiro: Record. 2001. 174 p.

SCOLES, R. e R. GRIBEL. Population structure of Brazil nut (Bertholletia excelsa, Lecythidaceae) stands in two areas with different occupation histories in the Brazilian Amazon. . Human Ecology, v.39, n.4, p.455-464. 2011.

SCOLES, R., R. GRIBEL et al. Crescimento e sobrevivência de castanheira (Bertholletia excelsa Bonpl.) em diferentes condições ambientais na região do rio Trombetas, Oriximiná, Pará. Boletim do Museu Paraense Emilio Goeldi, v.6, n.3, set-dez 2011, p.273-293. 2011.

SILVEIRA, N. H. O Conceito de atenção diferenciada e sua aplicação entre os Yanomami. In: E. J. LANGDON e L. GARNELO (Ed.). Saúde dos Povos Indígenas: reflexões sobre antropologia participativa. Rio de Janeiro: Contracapa/ABA, 2004, p.111-127.

SIOLI, H. Amazônia: Fundamentos da ecologia da maior região de florestas tropicais. Rio de Janeiro RJ: Vozes. 1991

SMOLE, W. Yanoama A Cultural Geography. Austin USA: Texas Press. 1976. 272 p.

STRATHERN, M. O Efeito Etnográfico e outros ensaios. São Paulo: CosacNaify. 2014 (ensaios)

SZTUTMANN, R. Metamorfoses do Contra Estado: Pierre Clastres e as políticas ameríndias. Ponto Urbe, v.13, 31/12/2013, p.1-19. 2011.

TAYLOR, K. A geografia dos espíritos: o xamanismo entre os Yanomami setentrionais. In: E. J. LANGDON (Ed.). Xamanismo no Brasil Novas perspectivas. FLorianópolis: EdUFSC, 1996, p.117-152.

TSING, A. Margens indomáveis: cogumelos como espécies companheiras. Ilha, v.17, n.1, p.178-212. 2015.

VALENTIM, M. A. Extramundanidade e sobrenatureza. Revista Internacional de Filosofia, v.15, n.2, p.48-85. 2013. 
A Sobrenatureza da Catástrofe. Landa, v.3, n.1, 09/2014, p.3-25. 2014.

VAZ, A. e P. A. A. BALTHAZAR. Povos indígenas isolados, autonomia, pluralismo jurídico e direitos da natureza, relações e reciprocidades. Boletín Onteaiken v.15, mayo 2013, p.85-101. 2013.

VAZ, A., M. E. COELHO et al. Povos Indígenas Isolados e de Recente Contato no Brasil: Políticas, direitos e problemáticas.: Comitê Indígena Internacional para a Proteção dos Povos em Isolamento e Contato Inicial da Amazônia, Gran Chaco e Região Oriental do Paraguai (CIPIACI) 2013.

VIVEIROS DE CASTRO, E. B. Os Pronomes Cosmológicos e o Perspectivismo Ameríndio. MANA v.2, n.2. 1996.

- A Inconstância da Alma Selvagem e outros Ensaios de Antropologia. São Paulo:

Cosac-Naify. 2002

Perspectival Anthropology and the Method of Controlled Equivocation. Tipití: Journal of the Society for the Anthropology of Lowland South America, v.2, n.1, p.1. 2004. . Metafísicas canibais. São Paulo: Cosacnaify/N-1. 2015. 288 p.

WAGNER, R. The Invention of Culture. Chicago: Chicago Press. 1981. 119 p.

WALKER, R. e K. HILL. protecting Isolated Tribes. ScienceMag, v.348, n.6239, p.1061. 2015.

WELCH, J. R., C. E. COIMBRA JR et al. Na primeira Margem do Rio: Território e Ecologia do Povo Xavante de Wedezé. Rio de janeiro: Museu do Índio, v.6. 2013. 244 p. (Publicação Avulsa ) 